UNIVERSIDADE DE SÃO PAULO

ESCOLA DE COMUNICAÇÕES E ARTES

\title{
OS MODELOS CROMÁTICOS DO TEUFELSMÜHLE E OMNIBUS NA MÚSICA DE F. CHOPIN
}

VANESSA RODRIGUES NONIS

São Paulo

2011 
VANESSA RODRIGUES NONIS

\title{
OS MODELOS CROMÁTICOS DO TEUFELSMÜHLE E OMNIBUS NA MÚSICA DE F. CHOPIN
}

\begin{abstract}
Dissertação apresentada ao Programa de Pós-Graduação em Música da Universidade de São Paulo, Área de Concentração: Processos de Criação Musical, na linha de pesquisa: Técnicas Composicionais e Questões Interpretativas, como exigência parcial para obtenção do título de Mestre em Música, sob a orientação da Profa $D^{a}$ a Luciana Sayure Shimabuco
\end{abstract}

\section{Versão Corrigida}

Original disponível no Programa de Pós-Graduação em Música

São Paulo 
BANCA EXAMINADORA 


\section{AGRADECIMENTOS}

À CAPES, pelo apoio financeiro que contribuiu para o desenvolvimento desta pesquisa.

À profa Drạ Luciana Sayure, admirável instrumentista, sempre foi uma inspiração e uma referência para a minha formação musical. Minha enorme gratidão pela oportunidade, orientação, paciência, confiança incondicional e amizade de tantos anos.

Minha mais profunda gratidão e admiração à querida profa Ms. e grande amiga Marisa Ramires, inquestionável inteligência e talento musical, de quem recebi o incentivo e a bibliografia que deu origem a esta pesquisa. Suas sugestões, paciência, confiança, apoio incondicional e principalmente amizade sincera é que tornou possível a realização deste trabalho.

À querida Aline Schmidt, companheira de estudo e amiga de longa data, por disponibilizar o principal artigo em alemão, pela tradução do resumo, conferência de citações e, sobretudo pelo apoio, incentivo e enorme atenção nos momentos difíceis e decisivos.

Ao querido amigo Mário Videira, por suas valiosas orientações, materiais levantados, localização de obras com os modelos cromáticos e por suas traduções dos textos em alemão, que redimensionaram esta pesquisa. Seu comprometimento, apoio, incentivo e amizade foram essenciais.

Minha gratidão e admiração à profạ Ms. Marisa Lacorte, por seus ensinamentos, sensibilidade e sabedoria, que inquestionavelmente marcaram meu desenvolvimento musical e pessoal.

Ao admirável pianista prof. Dr. Eduardo Monteiro, por sua Inteligência, generosidade e atenção dispensada. Meus sinceros agradecimentos por aceitar fazer parte da banca de qualificação e pelas decisivas sugestões feitas por ocasião deste exame.

A profa Dra Yara Casnók, pela oportunidade de participar de encontros que instigaram paralelos desta pesquisa com Bach. Agradeço pelo envio de materiais, por aceitar fazer parte da banca de qualificação e pelas valiosas sugestões.

Ao compositor e professor Willy Corrêa de Oliveira, com quem tive a honra de ter aulas durante 1998. Embora neste período ainda não fosse possível compreender e compartilhar de seus pensamentos, sua presença se manteve, de alguma forma, e gerou transformações nestes últimos anos. Por seu espírito crítico, inteligência e sabedoria que, sem dúvida, contribuíram para a realização desta pesquisa. 
A profa Dra Monica Lucas, pela generosidade, por me apresentar à Áurea Ambiel e pela oportunidade de participar de suas aulas de retórica na ECA/USP.

A Áurea Ambiel, pela atenção dispensada e contribuições com informações específicas sobre Música Antiga.

Ao Alexandre Rincon, pelas edições e gravações dos exemplos musicais, traduções de textos e toda a assistência indispensável. Sua atenção e generosidade foram fundamentais.

Ao Alexandre Zamith, que também instigou e motivou esta pesquisa, por sua sabedoria musical, interesse e apoio.

Ao João Lourenço, pela edição de exemplos e gráficos, assim como pelas sugestões e leitura cuidadosa que fez desta dissertação, mas principalmente por sua atenção e palavras de incentivo.

Aos colegas da pós-graduação da FMU: David Suriá, Maura de Moura, João Lourenço, Heraldo Paarmann, Fábio Ramazzina, Alexandre de Orio, Silmara Fernandes, Mateus Barrinha, Ricardo Dardes, Tamara Stuchi, Josefina Capitani, Angela Levy e Eliane Barbosa. Pela presença na minha primeira aula expositiva sobre o objeto de estudo desta dissertação, mas acima de tudo pelo interesse, apoio e recepção nesta ocasião.

Ao José Luiz, que gentilmente disponibilizou excelentes pianos para a gravação e estudo de obras musicais que estão expostas neste trabalho.

A Janete Angelino, por toda sustentação psicológica imprescindível nestes últimos anos.

Ao querido Victor Lima Garcia, pela paciência, compreensão, dedicação e apoio em todos os momentos.

A Vanessa Felipe, Elenice Cipriano, Viviane do Amaral, Márcia Regina Vittore, Viviane Louro, Verônica Pires Macedo, Andrea Pardo e Vanessa Gargantini. Pelas palavras, atenção e incentivo.

Meu profundo amor e gratidão aos meus pais José e Sueli, meus irmãos Allan e Dante, e minha avó Clara, que sempre estiveram ao meu lado, me deram todo o suporte necessário e que souberam entender minha ausência nestes últimos tempos. 
À Marisa Ramires 


\section{RESUMO}

Teufelsmühle e omnibus são nomenclaturas empregadas para designar modelos estruturais profundamente aparentados, que envolvem cromatismo, polifonia, modulação, relação de terças menores, inversão simétrica, condução de vozes e reinterpretações enarmônicas de acordes.

Trata-se de padrões cujas origens remontam no mínimo à prática musical do século XVIII e que já nesta época começaram a ser codificados por teóricos. No entanto, estas sequências cromáticas só receberam estudos específicos a partir do final da década de 1960 por duas principais correntes de pesquisa, a alemã, que emprega o termo Teufelsmühle e a americana, com a designação omnibus.

Dividido em duas partes, este trabalho expõe inicialmente os aspectos estruturais do Teufelsmühle e omnibus, a partir de uma revisão bibliográfica e apontamentos críticos realizados por esta pesquisa. Já a segunda parte busca vislumbrar a representatividade e abrangência destes modelos cromáticos no processo composicional de F. Chopin, evidenciando o modo com que tal princípio foi utilizado e os principais contextos em que está inserido.

\section{Palavras-chave:}

Teufelsmühle; omnibus; cromatismo; polifonia; reinterpretação enarmônica; Chopin 


\begin{abstract}
Teufelsmühle and omnibus are nomenclatures used to designate structural models deeply similar, which involve chromaticism, polyphony, modulation, minor thirds relation, symmetrical inversion, voice leading, and enharmonic reinterpretations of chords.

They refer to patterns originated at least with the musical practice of the eighteenth century, and that even in that time started to be codified by theorists. Nevertheless, these chromatic sequences were studied specifically only beginning at the end of the 1960s and done by two main streams of research, the German, which uses the term Teufelsmühle, and the American, with the designation omnibus.

Divided in two parts, this study presents initially structural aspects that refer to Teufelsmühle and omnibus based on a literature review and critical comments developed in this research. The second part intends to look at the relevance of these chromatic models and what they encompass in the compositional process of Chopin, showing the way such principle was used and the main contexts in which it happens.
\end{abstract}

\title{
Keywords:
}

Teufelsmühle; omnibus; chromaticism; polyphony; enharmonic reinterpretation; Chopin 
"Todo conhecimento pressupõe um choque, um despertar." Willy Corrêa de Oliveira 


\section{PARTE I - TEUFELSMÜHLE E OMNIBUS: ASPECTOS ESTRUTURAIS}

CAPÍTULO 1 - TEUFELSMÜHLE: A VISÃO ALEMÃ. 06

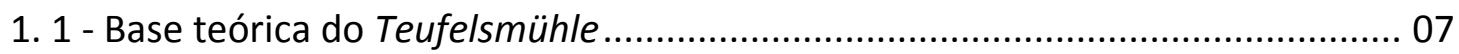

1. 2 - Definição e classificação em versões ............................................................11

1. 3 - Reinterpretação enarmônica e o acorde diminuto com sétima diminuta ..........17

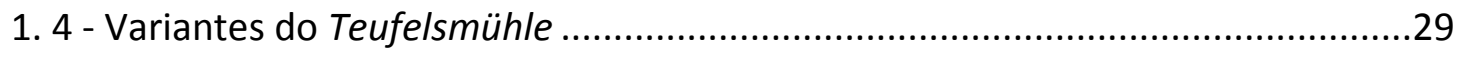

1. 4.1 - Omissão do acorde de dominante com sétima ........................................29

1. 4. 2 - Substituição do acorde de dominante com sétima ..................................31

1. 4. 3 - Substituição do acorde menor com quarta e sexta .................................32

1. 4. 4 - Variante do Teufelsmühle versão B .........................................................34

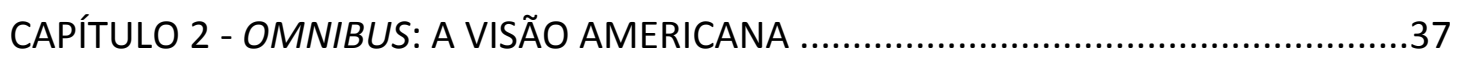

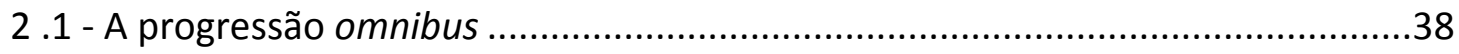

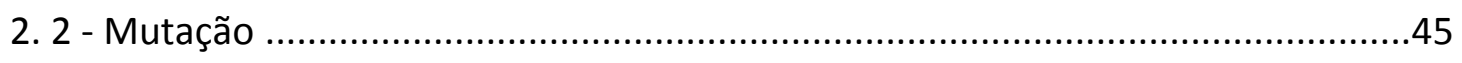

2. 3 - Variantes da progressão omnibus .....................................................................

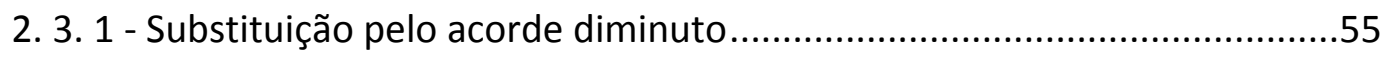

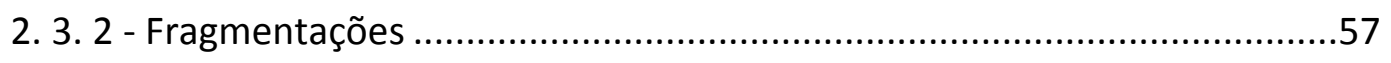

2. 3. 3 - Omissões e repetições de acordes ........................................................59

2. 3. 4 - Alterações na estrutura da série...............................................................62 
PARTE II - TEUFELSMÜHLE E OMNIBUS NA PRÁXIS COMPOSICIONAL DE CHOPIN: UMA AMOSTRAGEM EM DIFERENTES GÊNEROS

CAPÍTULO 3 - USOS E SONORIDADES CARACTERÍSTICAS .66

3.1 - Andamento .69

3. 2 - Fragmentos .72

3. 3 - Variantes .78

3. 3. 1 - Substituição do acorde menor com quarta e sexta . .78

3. 3. 2 - Omissões de acordes ... .82

3. 3. 3 - "Variante de Chopin" .86

CAPÍTULO 4 - CONTEXTOS MUSICAIS . .96

4.1 - Associação com incerteza, melancolia, tristeza e morte .97

4. 2 - Passagens não temáticas 108

4. 3 - Contraste para preparação de ponto culminante 120

CONSIDERAÇÕES FINAIS .135

REFERÊNCIAS BIBLIOGRÁFICAS 144

TEXTOS ORIGINAIS DAS CITAÇÕES 148

ÍNDICE DE EXEMPLOS MUSICAIS .162 


\section{INTRODUÇÃO}

\section{Teufelsmühle e Omnibus}

O emprego de sequências cromáticas permeia a literatura musical de diferentes épocas, estilos e gêneros. As diversas funções atribuídas ou assumidas por tais passagens manifestam-se diretamente na práxis composicional e conseqüentemente revelam implicações para a interpretação. Uma evidência do significado que tais sequências cromáticas imprimiam na prática musical pode ser vista, por exemplo, na "teoria dos afetos" da música Barroca. Tal argumentação introduz o objeto desta pesquisa: Teufelsmühle e omnibus, por tratar-se de progressões cromáticas que obedecem a padrões, presentes há séculos na música, mas que só receberam atenção e estudos específicos nas últimas décadas.

Segundo pesquisadores, estas estruturas podem ser identificadas já em 1727, como por exemplo no recitativo 73 da Paixão Segundo São Mateus de J. S. Bach. Contudo, é possível verificar que tais sequências são ainda mais freqüentes a partir do final do século XVIII e permanecem até mesmo no século XX.

Teufelsmühle e omnibus são nomenclaturas empregadas para designar modelos estruturais profundamente aparentados ${ }^{1}$, que envolvem cromatismo, polifonia, modulação, relação de terças menores, inversão simétrica, condução de vozes e reinterpretações enarmônicas de acordes.

Trata-se de padrões cujas origens remontam no mínimo ao século XVIII e que em 1776 começaram a ser codificados por teóricos, como o alemão Georg Joseph Vogler (1749$1814)^{2}$. Em 1805, Emmanuel Aloys Förster (1748-1823) ${ }^{3}$ utilizou a expressão “o chamado Teufelsmühle" no seu manual para baixo contínuo em menção a este padrão de harmonização cromática. No entanto, vale ressaltar que era comum que esta estrutura estivesse nos manuais de composição sem efetivamente ser mencionada sob o nome Teufelsmühle (DITTRICH, 2007, p. 108). Embora compositores e teóricos da época já conhecessem e utilizassem estes modelos de harmonização cromática, não havia uma

\footnotetext{
1 É apontada também a utilização do termo em dinamarquês djævlemøllen vinculado a estes modelos. (DITTRICH, 2007, p. 108, nota 5).

${ }^{2}$ Vogler atuou como compositor, organista, professor e teórico. Suas composições compreendem músicas de câmara, óperas e um vasto número de obras sacras. Além de exímio organista/recitalista, foi considerado um revolucionário por seus contemporâneos no âmbito teórico.

${ }^{3}$ Influente teórico nascido na região da Silesia, Förster também exerceu o ofício de compositor e professor.
} 
preocupação em identificar e justificar sua presença, definir sua função ou mesmo assumir uma denominação única.

Foi somente a partir do final da década de 1960 que foram publicados os primeiros trabalhos dedicados à formulação do conceito dessas estruturas cromáticas e à observação de suas implicações no repertório. Atualmente destacam-se duas correntes de pesquisas: a alemã, que emprega o termo Teufelsmühle e a americana, com a expressão omnibus ${ }^{4}$.

Elmar Seidel $(1966,1969,1981)$ é considerado pioneiro e principal nome da vertente alemã, que conta ainda com outros autores, tais como Martin Zenck (1987), Christian Thorau (1993), Peter Giesl (2001), Hartmut Fladt (2005) e Marie-Agnes Dittrich (1991, 2007). Do lado americano, Victor Fell Yellin ${ }^{5}(1972,1976,1998)$ é tido como o primeiro autor a desenvolver pesquisas e textos específicos sobre o assunto. Ligados a ele figuram ainda Robert Wason (1985) e Paula Telesco $(1993,1998,2001)$, entre outros.

Em 2007, no artigo "Teufelsmühle und Omnibus" publicado na Zeitschrift der Gesellschaft für Musiktheorie [Revista da Sociedade de Teoria Musical], Marie-Agnes Dittrich constata uma separação entre autores alemães e americanos e aponta algumas questões que podem ter contribuído para tal isolamento. Segundo a autora, a tradução literal do termo Teufelsmühle para o inglês Devil's Mill, empregada pelo musicólogo americano Robert W. Wason (1985, p. 24), provavelmente dificultou a recepção do termo alemão e da bibliografia correspondente. Da mesma forma, a adoção do termo omnibus pelos americanos também contribuiu para a desvinculação dos estudos entre estes dois países. Desta forma, Seidel e Yellin foram os primeiros a investigar este assunto, não conheceram o trabalho um do outro e acabaram por desenvolver este tema de forma independente, com descrições, deduções e classificações diferentes. Dittrich argumenta que "o fato de que até o momento não se dispõe de um termo obrigatório [ou seja, uma terminologia consolidada para estes modelos], dificulta uma visão geral sobre o estado atual da discussão" (DITTRICH, 2007, p. 108). A autora acrescenta também que até mesmo as pesquisas realizadas por computadores atualmente acabam por não ajudar nesta integração, visto que em palavraschave são colocados apenas termos como enarmonia, cromatismo, simetria, etc.

Ocorre então que toda bibliografia e produção acadêmica sobre este assunto é exclusivamente estrangeira e concentrada em duas correntes, que permanecem

${ }^{4}$ O termo Teufelsmühle é traduzido como moinho ou roda do diabo, enquanto que a palavra omnibus vem do latim e significa para todos ou por todos. Vale ressaltar que a associação destas expressões a tais modelos estruturais é de origem obscura, cf. DITTRICH (2007, p. 116) e Yellin (1998, p. 99).

${ }^{5}$ Nascido em Boston (1924 - 2005), estudou composição em Harvard com Walter Piston e foi regente e professor da Faculdade de Artes e Ciências de Nova lorque. 
atualmente, de forma geral, sem interação. Diante deste problema levantado e da importância histórica destas sequências cromáticas, associado ainda a pouca difusão destes conceitos e sua abrangência, esta dissertação tem como objetivo expor as definições e abordagens propostas por estas vertentes mencionadas, a fim de destacar as similaridades e divergências entre elas, além de promover apontamentos críticos vinculados à discussão deste tema.

Além disso, a pesquisa irá apresentar o resultado de uma investigação do Teufelsmühle e omnibus dentro de peças selecionadas da obra de Frédéric Chopin. Este estudo pretende evidenciar a representatividade e importância destas estruturas em seu processo composicional, explicitando o modo com que tal princípio foi utilizado e os principais contextos envolvidos.

De forma geral, nos textos dos pesquisadores mencionados é possível encontrar diferentes posicionamentos relacionados às hipóteses de origem do Teufelsmühle e omnibus, discussões que embora sejam correlatas extrapolam o âmbito desta pesquisa. Assim, esta dissertação irá se concentrar nos trabalhos de Elmar Seidel, que constituem um importante referencial bibliográfico para todos os autores que se dedicam ao assunto, e no artigo Teufelsmühle und Omnibus de Marie-Agnes Dittrich, que oferece significativa contribuição para o estudo deste tema, à medida que propõe uma visão conciliadora entre estas duas principais correntes de pesquisa e descreve categorias de classificações para estas estruturas em análise musical. Quanto aos referenciais vinculados a perspectiva americana, serão utilizados os estudos realizados por Victor Yellin e Paula Telesco, uma vez que representam as principais fontes bibliográficas em língua inglesa.

Em relação à organização geral, o trabalho será dividido em duas partes. A primeira, constituída por dois capítulos, será dedicada aos aspectos estruturais do Teufelsmühle e omnibus enquanto que a segunda parte, também estruturada em dois capítulos, será destinada a investigação destas sequências cromáticas na música de Chopin.

O primeiro capítulo irá apresentar a perspectiva alemã enquanto que o segundo será destinado à visão americana. Para tanto, as exposições estruturais serão feitas, num primeiro momento, com exemplos isolados e sem contexto para em seguida serem demonstradas em passagens da literatura musical ${ }^{6}$. A complexidade do assunto requer pressupostos teóricos que, por vezes, são omitidos ou pouco detalhados na bibliografia específica sobre o omnibus

\footnotetext{
${ }^{6}$ Os exemplos catalogados ou listados por outros autores serão sempre indicados, ao passo que todos os que não possuírem referência fazem parte das contribuições desta pesquisa.
} 
ou Teufelsmühle. Tal fato estimulou uma preocupação didática na organização dos itens dos capítulos 1 e 2, atendida pela inserção de pré-requisitos e a criação de critérios de classificação para a compreensão da estrutura.

A segunda parte desta dissertação promove a aplicação dos conhecimentos obtidos nos dois capítulos iniciais na música de Chopin, a partir da organização de tópicos que envolvem usos, sonoridades características e contextos musicais. Para cada item, os exemplos serão acompanhados por uma redução analisada, com a finalidade de facilitar a localização e a compreensão destas sequências no trecho em questão ${ }^{7}$. 0 vínculo com aspectos gerais tais como dinâmica, andamento e textura, torna-se pertinente e necessário à integração com o momento em que o Teufelsmühle ou omnibus está inserido na obra.

Vale ressaltar que a opção por F. Chopin se deve, primeiramente, a uma experiência musical com a obra do compositor, enquanto intérprete e analista, associada à escassez de estudos específicos sobre o emprego das progressões do Teufelsmühle e omnibus em sua música. Além disso, seu tipo de escrita, que envolve, por vezes, uma polifonia extremamente elaborada, não evidente e com implicações na identificação destes modelos cromáticos, também constituiu um decisivo fator que instigou esta pesquisa.

Diante dos inúmeros exemplos musicais e da inexistência de discussões específicas sobre este assunto no meio acadêmico brasileiro, se fez necessário e fundamental a montagem de um cd que acompanha a dissertação e que traz as gravações de todas as passagens expostas no decorrer dos capítulos. A idéia é não somente ilustrar as sonoridades, mas também promover, inicialmente, o vínculo da codificação de aspectos estruturais e musicais com a escuta.

\footnotetext{
7 Torna-se relevante esclarecer que a cifragem que acompanha a maior parte dos exemplos refere-se às tipologias dos acordes e não aos graus de uma escala ou funções dentro de uma tonalidade. Caso a cifragem seja empregada no sentido tradicional da harmonia tonal, a indicação do tom da passagem anunciará este emprego convencional.
} 
TEUFELSMÜHLE E OMNIBUS:

aspectos estruturais
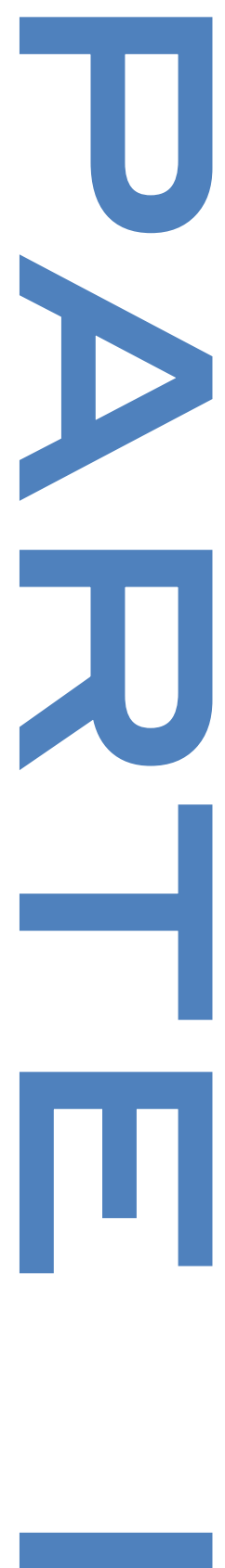


\section{CAPÍTULO 1}

\section{Teufelsmühle: a visão alemã}

A partir dos tratados de Abbé Vogler e Aloys Förster, Elmar Seidel produziu no final da década de 1960 materiais bibliográficos específicos sobre as sequências do Teufelsmühle com vínculos em análise musical. Dois significativos artigos foram publicados pelo autor, que logo se tornaram obras de referência para o estudo deste tema: o primeiro em 1969, sob o título "Ein chromatisches Harmonisierungs-Modell in Schuberts Winterreise" [Um modelo de harmonização cromática no Winterreise de Schubert]; e o segundo em 1981, "Über den Zusammenhang zwischen sogenannten Teufelsmuhle und dem 2. Modus mit begrenster transponierbarkeit in Liszts harmonik" [Sobre a relação entre o chamado Teufelsmühle e o segundo modo de transposição limitada na harmonia de Liszt].

Em seu texto de 1969 Seidel questiona a idéia de assumir, sem um estudo mais aprofundado das relações histórico/estruturais, certas passagens cromáticas como pertencente ao estilo pessoal do compositor ou mesmo como algo próprio do período romântico. Após investigar as tipologias, as relações e as funções dos acordes numa passagem do Lied Wegweiser de F. Schubert, o autor reconhece e classifica os modelos do Teufelsmühle, revelando tratar-se de padrões presentes em inúmeras obras musicais e com uma história de pelo menos cem anos de idade já em 1827. Para validar esta afirmação, cita vários exemplos da literatura musical, principalmente entre J. S. Bach, J. Haydn, W. A. Mozart e L. Beethoven.

Seguindo o viés histórico/estrutural, Seidel resgata em seu artigo de 1981 as referências a A. Förster e Abbé Vogler e promove discussões sobre as propriedades estruturais do Teufelsmühle, as quais se relacionam ao acorde diminuto e ao segundo modo de transposição limitada de Messiaen. Para tanto, passa a fazer uso de análises de peças do repertório, especialmente em Franz Liszt.

A partir destes referenciais, este capítulo irá enfatizar os aspectos estruturais do Teufelsmühle, organizados em quatro itens. Inicialmente será feita uma breve exposição dos modelos de harmonização da escala cromática de Vogler e Förster, com o objetivo de oferecer também um respaldo histórico e teórico para as sequências do Teufelsmühle. $\mathrm{O}$ item seguinte apresentará as definições e classificações em versões propostas por Elmar Seidel. No terceiro, 
a ênfase será dada às propriedades inerentes do Teufelsmühle, tais como a reinterpretação enarmônica e a relação com o segundo modo de transposição limitada de Messiaen. O último tópico será destinado às variantes e irá conter quatro divisões: omissão do acorde de dominante com sétima; substituição do acorde de dominante com sétima; substituição do acorde menor com quarta e sexta; e variantes da versão B do Teufelsmühle.

\section{1 - BASE TEÓRICA DO TEUFELSMÜHLE}

Os escritos de Abbé Vogler constituem referenciais imprescindíveis para todos aqueles que investigam as sequências do Teufelsmühle e do omnibus. Assim, a exposição da base teórica feita por Vogler se faz necessária para esclarecer e fundamentar a parte estrutural deste trabalho.

É notório que seus os tratados já evidenciavam o quão progressistas eram suas idéias para o século XVIII, como pode ser constatado em seus estudos sobre a escala cromática e a possibilidade dela conter todos os tons ${ }^{1}$. Outro aspecto digno de nota diz respeito à ênfase na questão da mudança de significado harmônico por meio da reinterpretação enarmônica, que recebeu um tratamento particular em seus textos.

Sob a designação Chromatische leiter [escala cromática], Vogler foi o primeiro teórico a expor padrões de harmonização da escala cromática, no entanto sem fazer qualquer associação com o termo Teufelsmühle. O teórico alemão chamou atenção para esta estrutura em momentos distintos em seus escritos: primeiramente em 1776, em Tonwissenschaft und Tonsetzkunst [A Ciência da Música e a Arte da Composição], posteriormente em 1778, em Kuhrpfälzische Tonschule [A Escola de Composição Palatina], e em 1802, em Handbuch zur Harmonielehre und für den Generalbaß [Manual de Harmonia e Baixo Figurado]. É importante salientar que a harmonização da escala cromática feita por Vogler sofreu mudanças na forma de apresentação em cada um destes manuais, fato que sugere que o teórico ainda estava num processo de formulação desta estrutura. Dentre as três exposições, atualmente a mais citada é a do Handbuch (1802), versão reproduzida e comentada em vários textos e artigos que tratam do Teufelsmühle ou mesmo do omnibus ${ }^{2}$.

\footnotetext{
1 Ilustrações deste pensamento podem ser encontradas no final de seu Handbuch zur Harmonielehre und für den Generalbab, com 132 exemplos de modulações cromáticas para todas as tonalidades (WASON, 1985, p. 15).

${ }^{2}$ Conferir Seidel (1969, p. 296) e (1981, p. 181), Wason (1985, p. 16), Telesco (1998, p. 263) e Yellin (1998, p. 15).
} 
Em Tonwissenschaft und Tonsetzkunst ${ }^{3}$ os modelos cromáticos do Teufelsmühle foram expostos sob a forma gráfica de um círculo dividido em 42 partes, na qual a única tríade em estado fundamental sobre Dó provavelmente se configura como ponto de partida (Ex. 1) 4 .

\section{Exemplo 1 - Vogler: Tonwissenschaft und Tonsetzkunst ${ }^{5}$ (1776)}

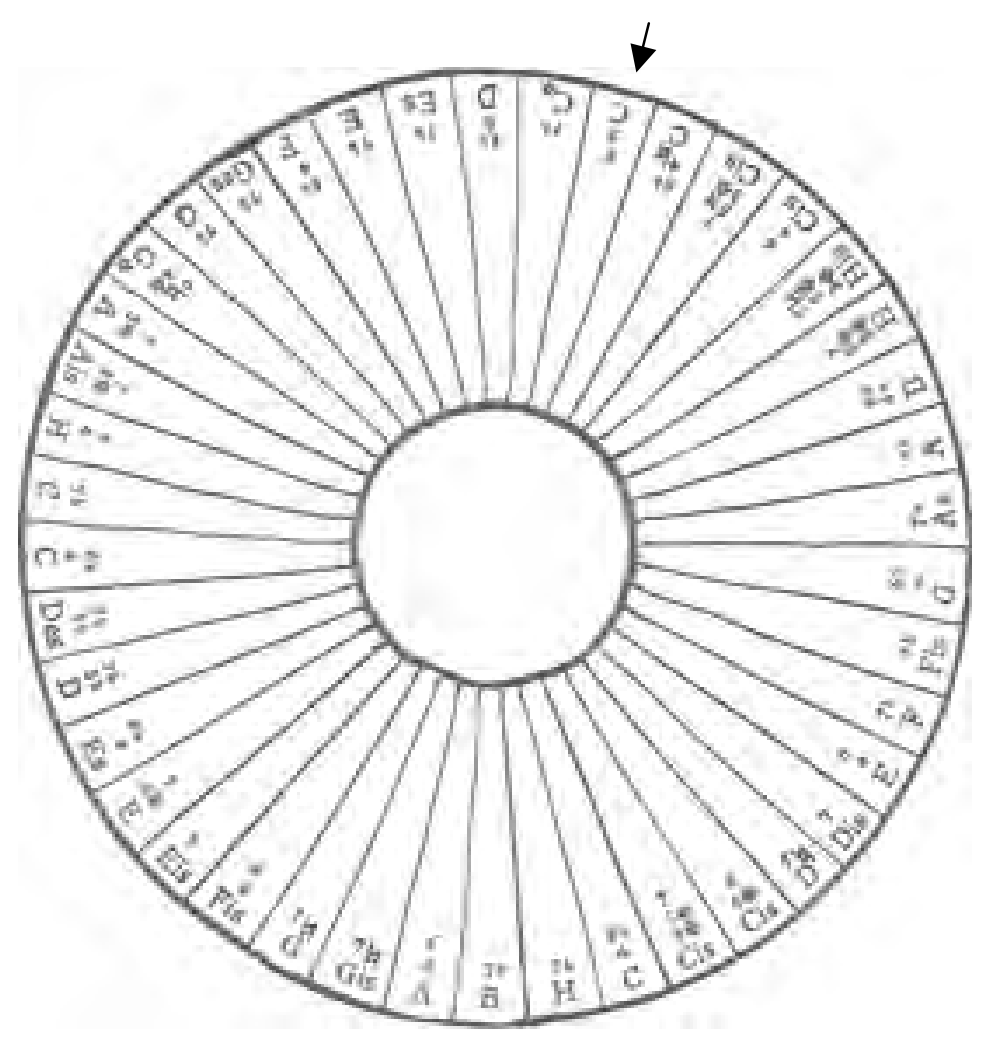

Em Kuhrpfälzische Tonschule, Vogler expõe novamente este modelo de harmonização cromática, no entanto, esta nova versão emprega uma notação no pentagrama sob a forma circular e com um triângulo inscrito, o qual divide os quinze compassos em três grupos de cinco. Tais delimitações são notadas no exemplo 2 com as siglas Cis, e, $g, b$ [Dó\#, Mi, Sol, Sib] - $d, f$, Gis, $h$ [Ré, Fá, Sol\#, Si] e Dis, fis, $a, c$ [Ré\#, Fá\#, Lá, Dó], as três possibilidades diferenciadas de acordes diminutos com sétima diminuta ${ }^{6}$.

\footnotetext{
${ }^{3}$ Em Tonwissenschaft, primeira parte do livro, Vogler faz considerações básicas sobre acordes, escalas e os conceitos de consonância e dissonância enquanto que em Tonsetzkunst, segunda parte, dispensa sua atenção à prática composicional, cf. Damschroder (1990, p. 369).

${ }^{4}$ Esta apresentação da escala cromática encontra-se citada apenas nos artigos de Elmar Seidel (1969, p. 290) e (1981, p. 180), no entanto, o autor não se detém em qualquer explicação sobre a construção deste círculo.

5 Figura extraída do manuscrito original de 1776, de uma versão impressa em 1970, editada por Georg Olms, p. 87.

${ }^{6}$ Cf. Damschoroder (2008, p. 134).
} 


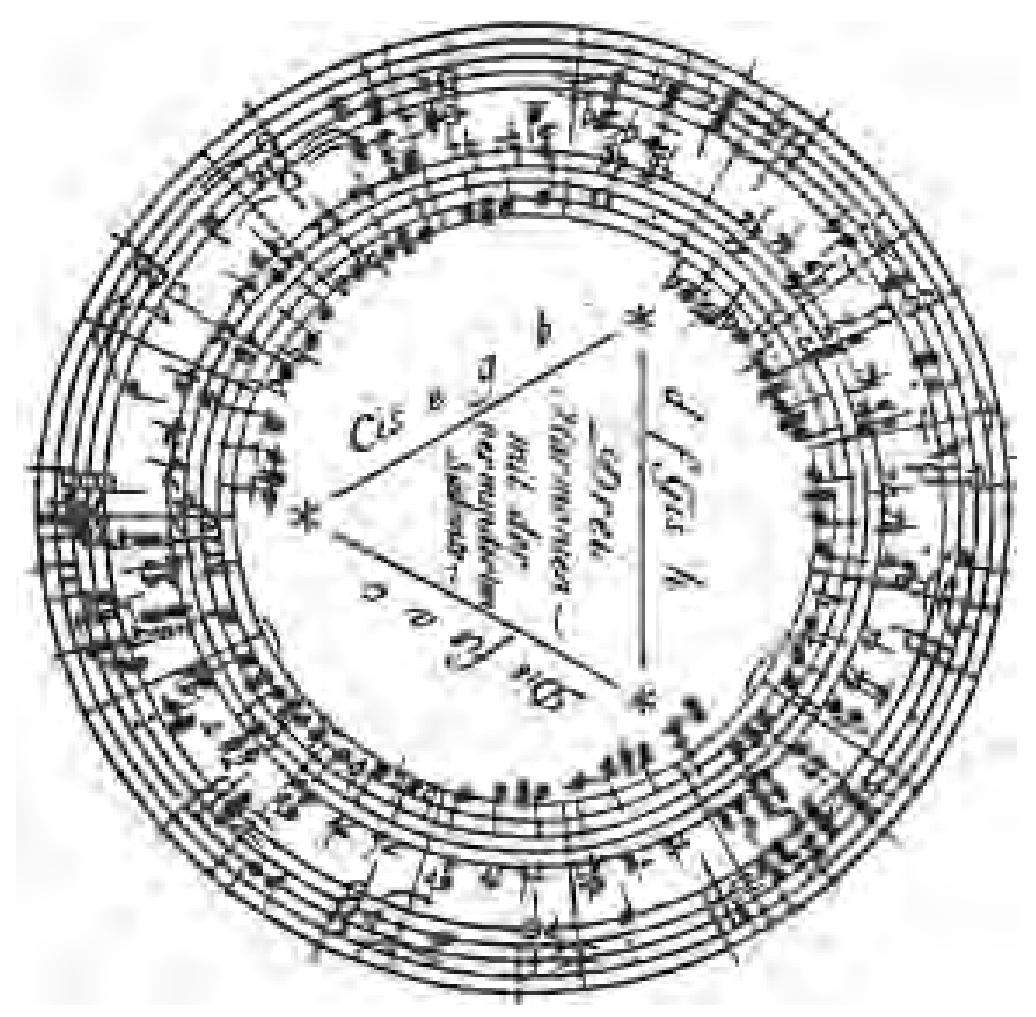

Uma abordagem estrutural do Teufelsmühle necessariamente pressupõe o entendimento do exemplo a seguir, extraído do Handbuch zur Harmonielehre und für den Generalbab, que compreende uma escala cromática no baixo harmonizada, excetuando o primeiro e o último acorde, por apenas três tipologias diferentes: acorde de sétima de dominante, acorde diminuto com sétima diminuta e acorde menor com quarta e sexta ${ }^{8}$. Assim, por meio de uma seqüência de acordes que obedece a um padrão definido, o baixo cromático parte da nota Dó, atinge ascendentemente sua oitava e retorna, de forma descendente (retrógrada), ao ponto de partida para cadenciar na tonalidade inicial de Dó maior. Esta preocupação tonal evidencia que para Vogler esta seqüência possuía um claro início e fim (SEIDEL, 1981, p.172).

\footnotetext{
${ }^{7}$ Figura exposta por Wason (1985, p. 17).

${ }^{8}$ É importante ressaltar que nesta dissertação o termo acorde menor com quarta e sexta não se aplica a uma segunda inversão, mas sim no sentido cadencial, ou seja, como acorde de dominante com quarta e sexta.
} 

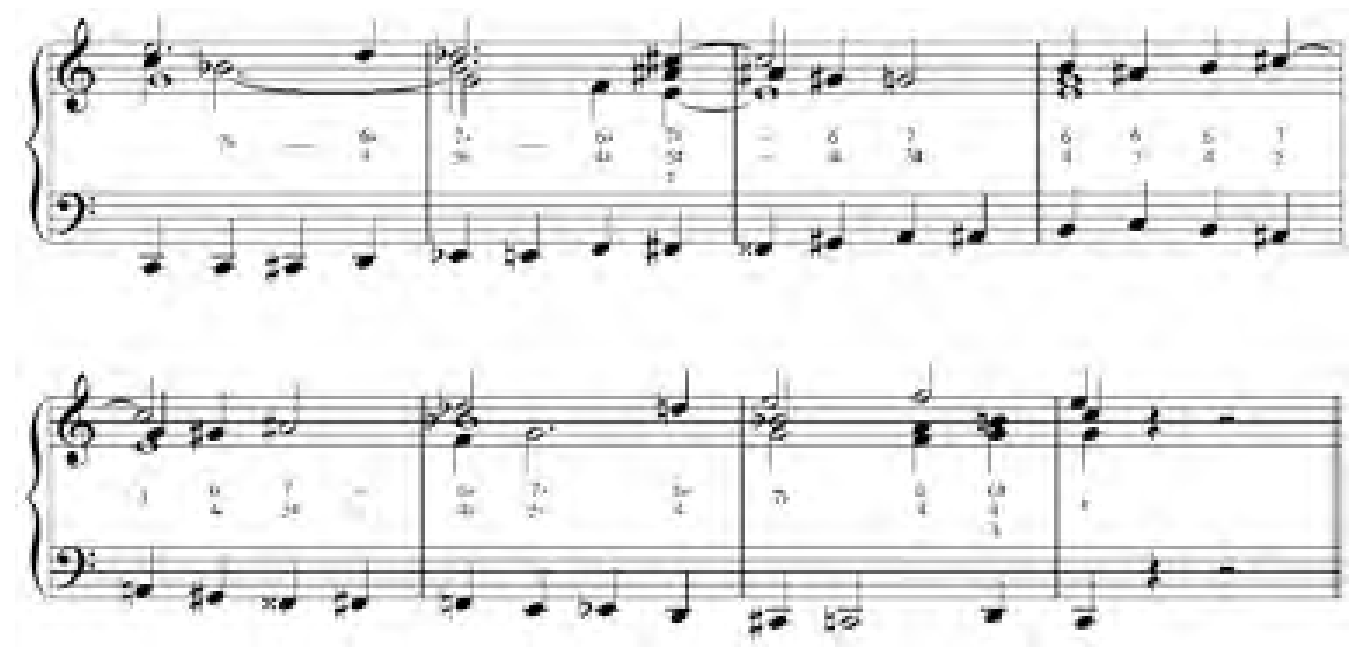

Esta apresentação de Vogler foi criticada por seu contemporâneo Aloys Förster em 1805, pelo uso restrito desta progressão vinculada a uma escala. Para Förster, a designação "Chromatisch Leiter" [escala cromática] assumida por Vogler contraria o princípio do Teufelsmühle, por se tratar de uma estrutura cíclica, ou seja, que pode ser prosseguida indefinidamente e, portanto, não se restringe a uma única escala no âmbito de uma oitava. Assim, no exemplo a seguir, extraído de seu Anleitung zum General-Bass [Manual para Baixo Contínuo], o baixo cromático ultrapassa a oitava em cinco sons.

\section{Exemplo 4 - Förster: Anleitung zum General-Bass ${ }^{10}$ (1805)}

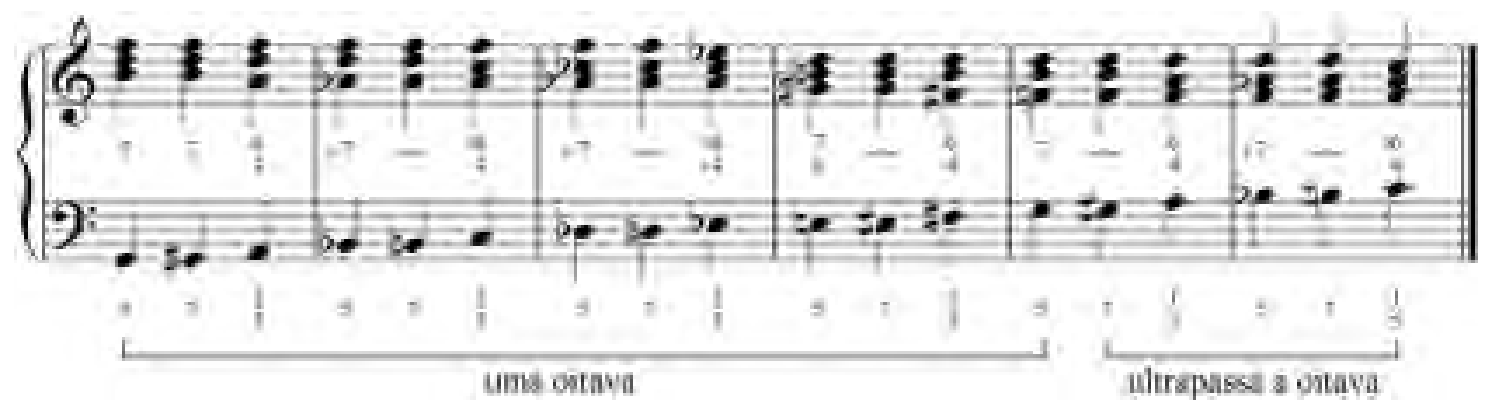

\footnotetext{
${ }^{9}$ Manual de 1802, p. 133 e seguintes, table XII apud (WASON, 1985, p. 16).

${ }^{10}$ Manual de 1805, extraído do parágrafo 93, exemplo 194 apud (SEIDEL, 1981, p. 172, exemplo 1).
} 


\section{2 - DEFINIÇÃO E CLASSIFICAÇÃO EM VERSÕES}

O termo Teufelsmühle é utilizado para denominar a harmonização de um baixo cromático, de acordo com os princípios propostos por Vogler, com o emprego das tipologias de acorde de dominante com sétima, acorde diminuto com sétima diminuta e acorde menor com quarta e sexta.

Uma análise da harmonização de Vogler (Cf. Ex. 3) permite notar que existe uma relação simétrica que rege sua estrutura: o acorde diminuto com sétima diminuta. $\mathrm{Na}$ redução a seguir (Ex. 5), a tríade inicial de Dó maior foi excluída e assim é possível visualizar o padrão $V^{7}-{ }^{\circ} 7$ - contidc ${ }_{4}^{6}$ la codificação de Vogler.

\section{Exemplo 5 - Redução da harmonização de Vogler: baixo cromático ascendente}

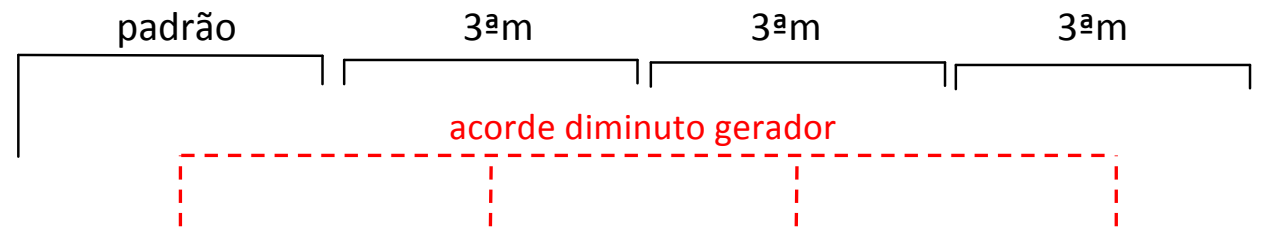

Grupo 1

Grupo 2

Grupo 3

Grupo 4

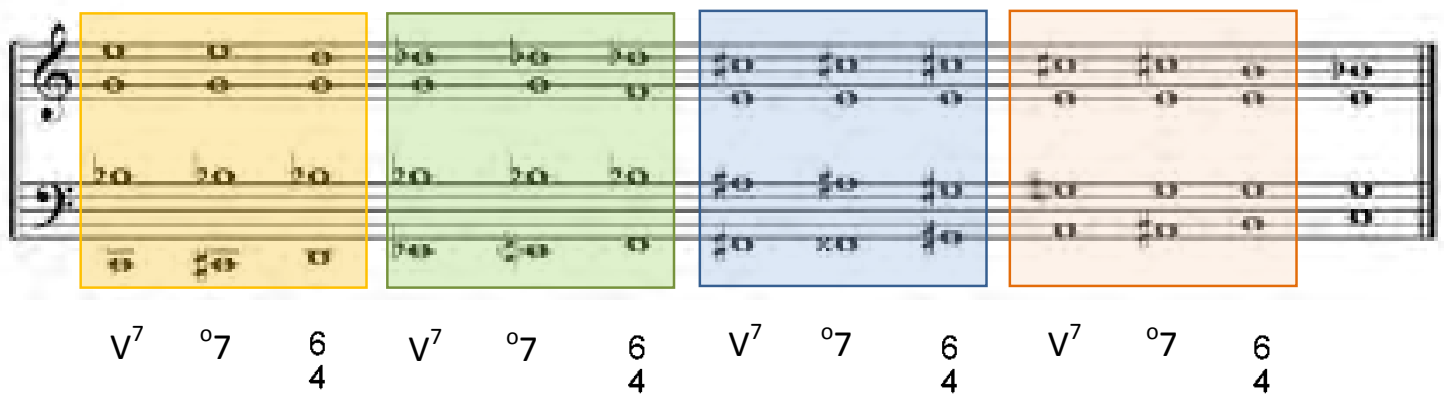

A partir desta ilustração verifica-se que o padrão é repetido por mais três vezes, sempre numa distância de terça menor acima, e que estas quatro apresentações perfazem a harmonização do baixo cromático ascendente. Além disso, todos os acordes de sétima de dominante encontram-se eqüidistantes por um intervalo de terça menor, da mesma forma como ocorre com todos os diminutos e todos os menores com quarta e sexta. Por fim, a observação da segunda tipologia de cada grupo permite entender que tais acordes, embora grafados de maneiras diferentes, são representações do mesmo diminuto, como assinalado neste exemplo com a linha vermelha tracejada.

Um ponto a ser destacado é o posicionamento de Seidel quanto às possibilidades de apresentação do Teufelsmühle. Uma distinção é feita a partir da classificação em versões $A, B$ ou $A B$, esta última designando uma mistura possível das duas anteriores. 
Para o autor, a versão A reproduz o modelo de Vogler e de Förster no que diz respeito às tipologias dos acordes. Assim, para um baixo cromático ascendente a estrutura envolve o seguinte padrão, que pode ser prosseguido indefinidamente: acorde de dominante com sétima; acorde de sétima diminuta; e acorde menor com quarta e sexta (Ex. 6). No entanto, é importante ressaltar que o Teufelsmühle versão A também pode estar disposto com o baixo cromático descendente, ou seja, pode apresentar-se na forma retrógrada, como assinalado no exemplo seguinte.

\section{Exemplo 6 - Seidel: Teufelsmühle versão A}

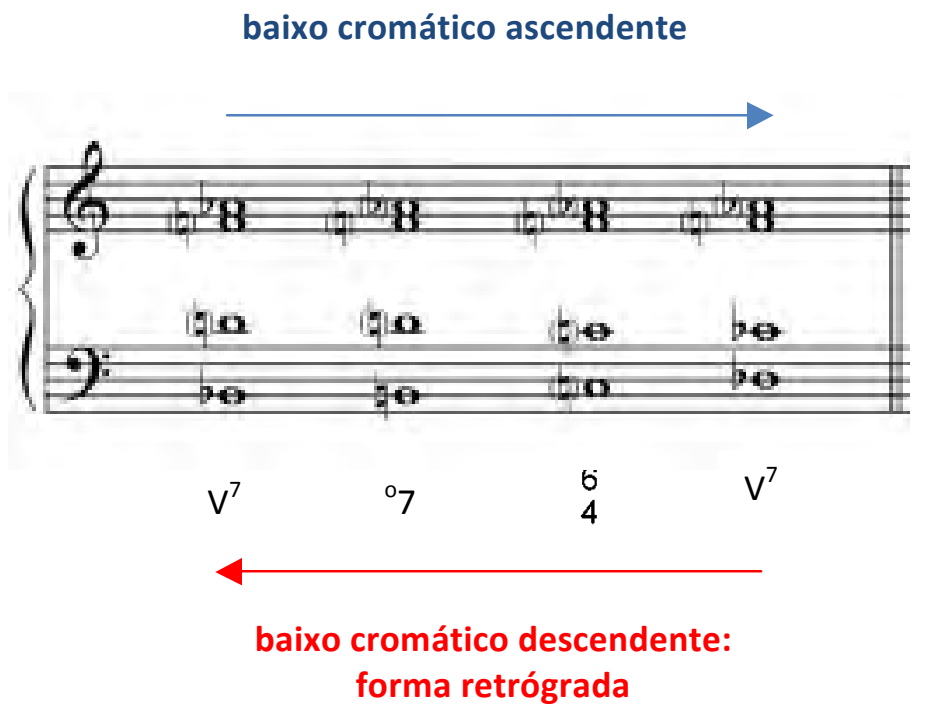

A versão A encontra-se empregada por Beethoven no desenvolvimento do primeiro movimento de sua Sonata Op. 2 no 3 em Dó maior, compassos 97 - 102, um momento formal que traduz uma propriedade inerente desta estrutura: a instabilidade tonal (Ex. 7).

Sobre um baixo cromático ascendente, a partir do compasso 97 é encontrado o uso das seguintes tipologias: dominante com sétima; diminuto; acorde menor com quarta e sexta; e dominante com sétima. Esta última tipologia representa o início da repetição da versão A terça menor acima, que na continuação será interrompida.

Com uma indicação de dinâmica ff, a entrada do Teufelsmühle neste exemplo é marcada por uma troca de figuração, que passa fazer uso de arpejos na mão direita enquanto que a esquerda se configura em acordes. Vale destacar ainda que a indicação $f$ é colocada por Beethoven a cada troca de tipologia da versão A. 
Exemplo 7 - Beethoven: Sonata Op. 2 no 3, 1 mov., comps. 95 - 104
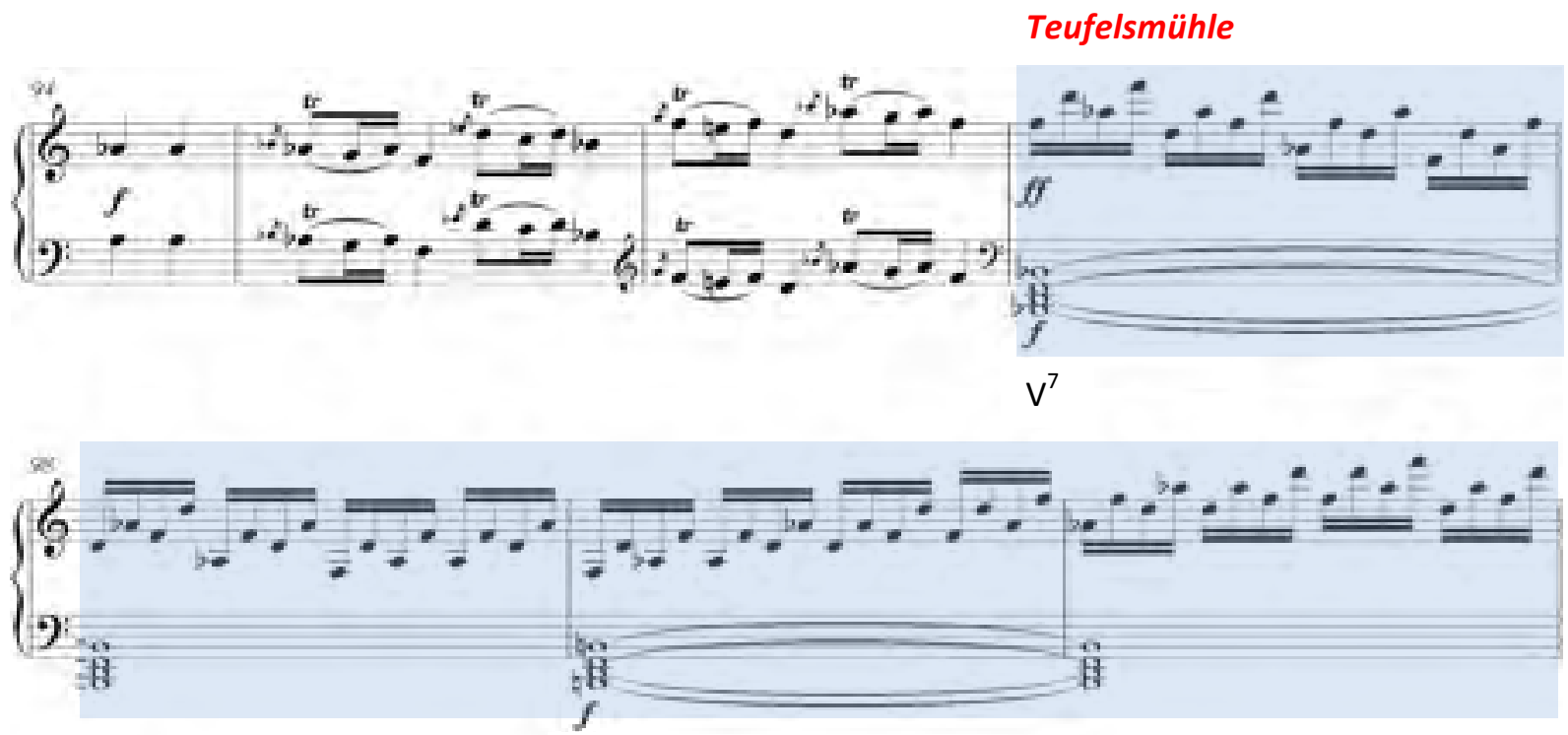

${ }^{0} 7$
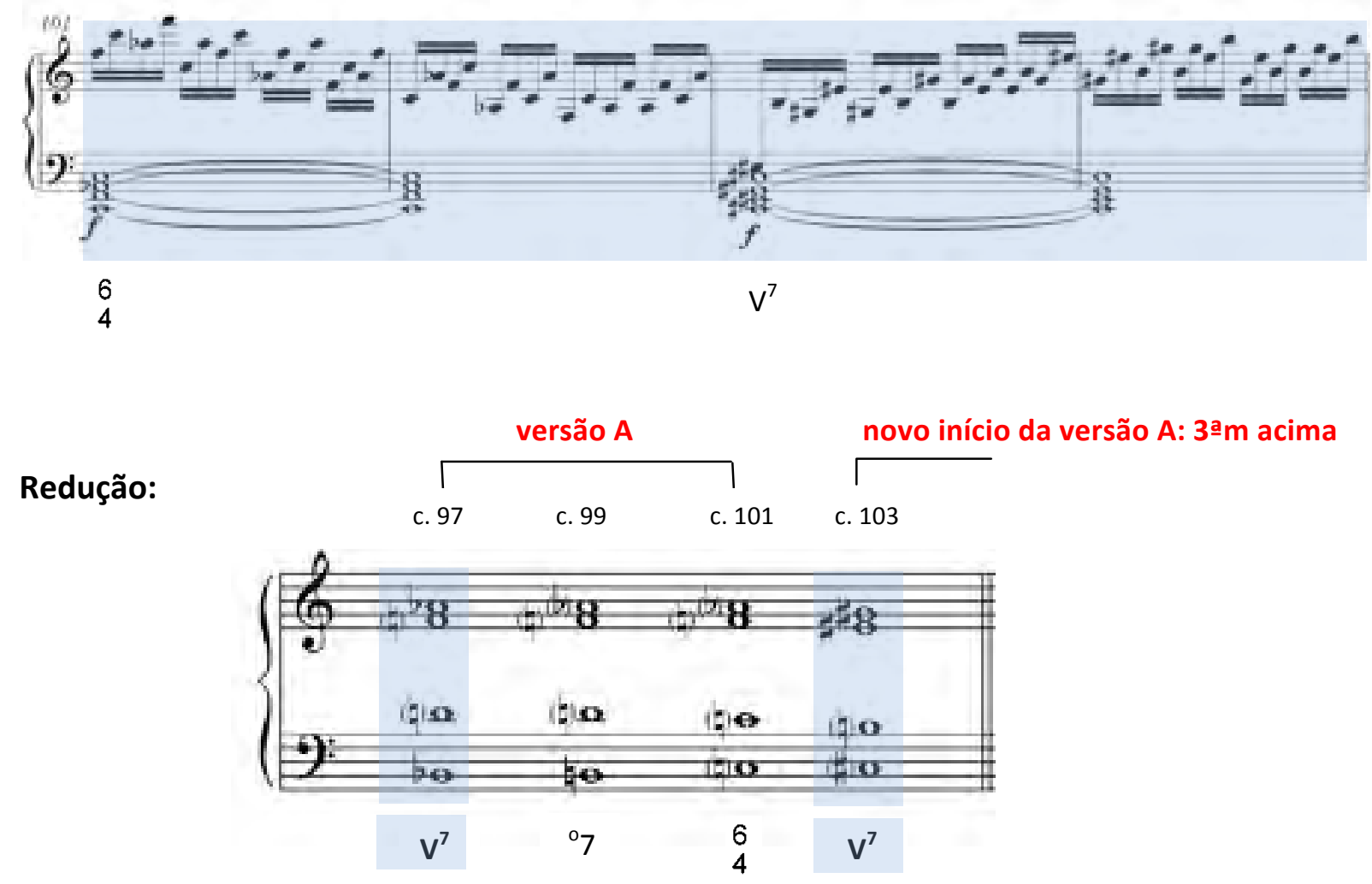

Uma vez estabelecida a versão A do Teufelsmühle, Seidel concentra-se no estudo de outras aparições desta estrutura que, embora com algumas alterações no padrão oferecido por Vogler, ainda conserva a mesma sonoridade. O reconhecimento no repertório e portanto, na práxis composicional, assegurou a ele a convicção de denominar como versão $B$ a sequência cromática que apresenta a substituição do acorde diminuto da versão A por uma 
dominante com sétima no baixo ${ }^{11}$. Assim, para um baixo cromático ascendente observam-se as seguintes tipologias: dominante com sétima; acorde de sexta aumentada/dominante com sétima no baixo; seguido pela acorde menor com quarta e sexta (Ex. 8). Igualmente à versão A, a versão B também pode estar disposta com o baixo cromático descendente, ou seja, pode ser encontrada na forma retrógrada, como indicada no exemplo seguinte.

\section{Exemplo 8 - Teufelsmühle versão B}

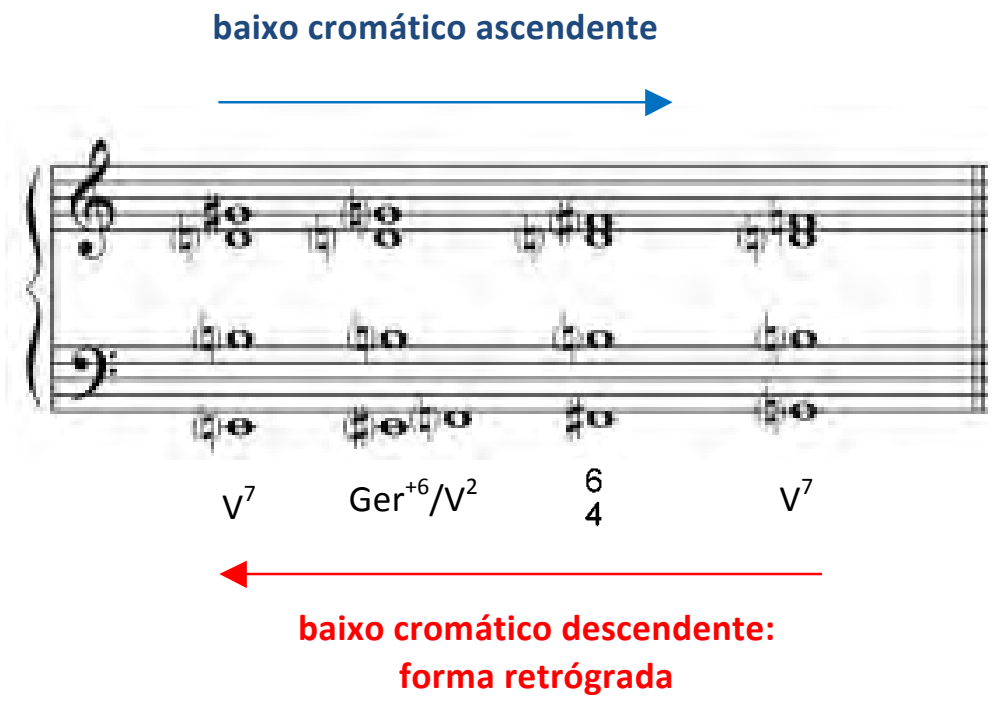

O trecho extraído do primeiro movimento do Concerto para flauta Op. 283 de Reinecke emprega três acordes da versão B do Teufelsmühle sobre um baixo cromático descendente nos compassos 105 - 106 (Ex. 9) ${ }^{12}$.

Exemplo 9 - Reinecke: Concerto para flauta Op. 283, 1 mov., comps. 105 - 106

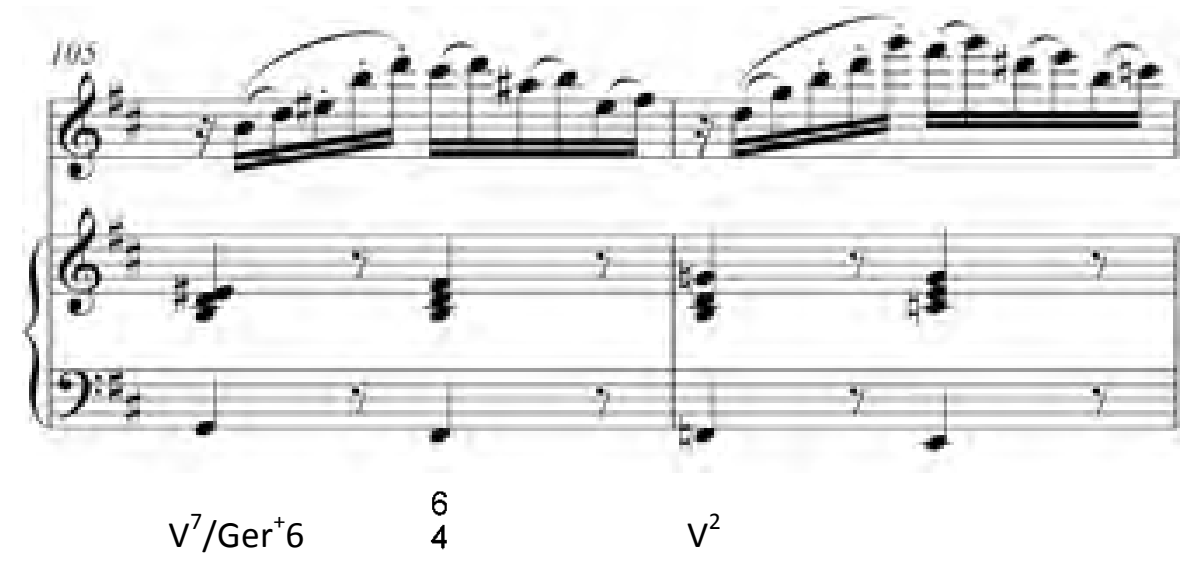

${ }^{11}$ Por vezes, o uso do acorde de dominante com a sétima no baixo no Teufelsmuhle também permite uma reinterpretação como acorde de sexta aumentada germânica, como será demonstrado no item seguinte.

${ }^{12}$ Comparar o exemplo 9 com o 8. 
Quanto à versão $A B$, Seidel não esclarece os detalhes e não cita exemplos, apenas refere-se à mistura das versões A e B do Teufelsmühle. Desta forma, devido a ausência de dados específicos, o exemplo seguinte (Ex. 10) oferece a harmonização de um baixo cromático ascendente, empregando elementos da versão B e da versão A com o intuito de ilustrar, numa exposição inicial, uma das várias possibilidades de integração destas duas versões.

\section{Exemplo 10 - Teufelsmühle versão AB}

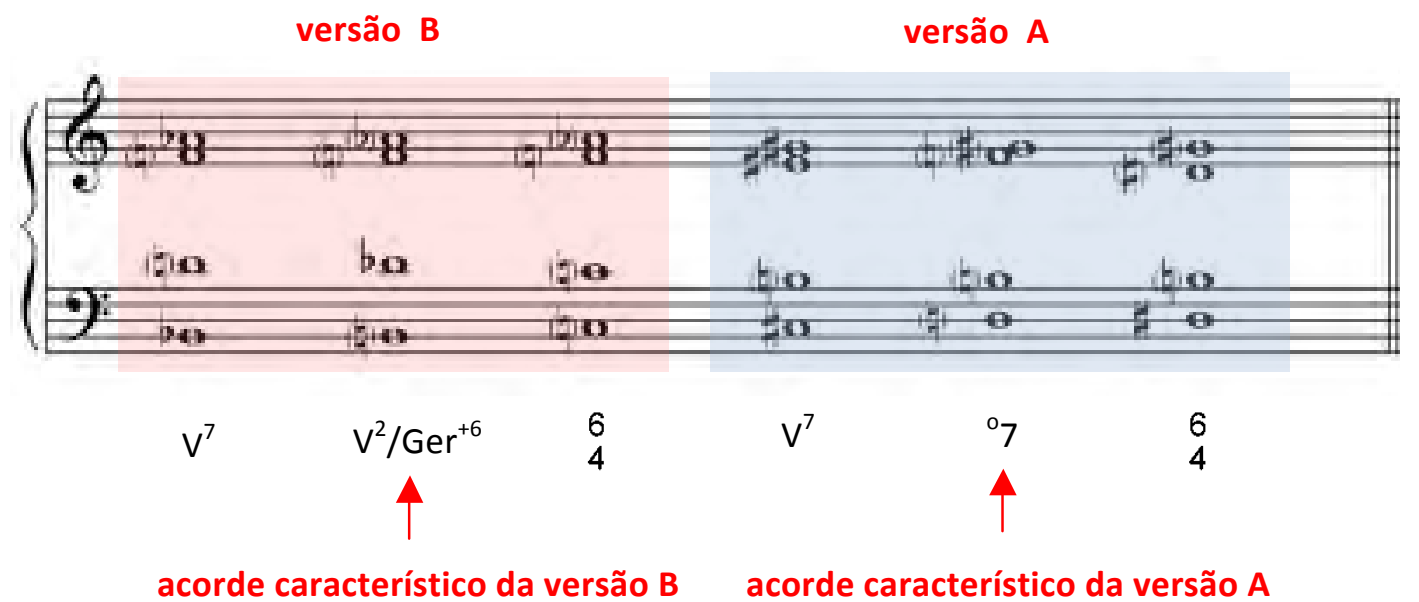

Um trecho do Rondó no 3 em Lá menor de C. P. E. Bach (comps. 142 - 156), seguido por sua redução analisada, demonstra o uso da versão $A B$ (Ex. 11). A observação da partitura permite constatar que se trata de uma harmonização que perfaz uma oitava com um baixo cromático descendente a partir de um único diminuto gerador (Sol $\left.\#^{\circ} 7\right)$. A versão $A$, assinalada em azul, é seguida de maneira consecutiva pela $B$, indicada em vermelho.

Exemplo 11 - C. P. E. Bach: Rondó no 3 em Lá menor, comps. 142 - 156 (YELLIN, 1998, p. 16)

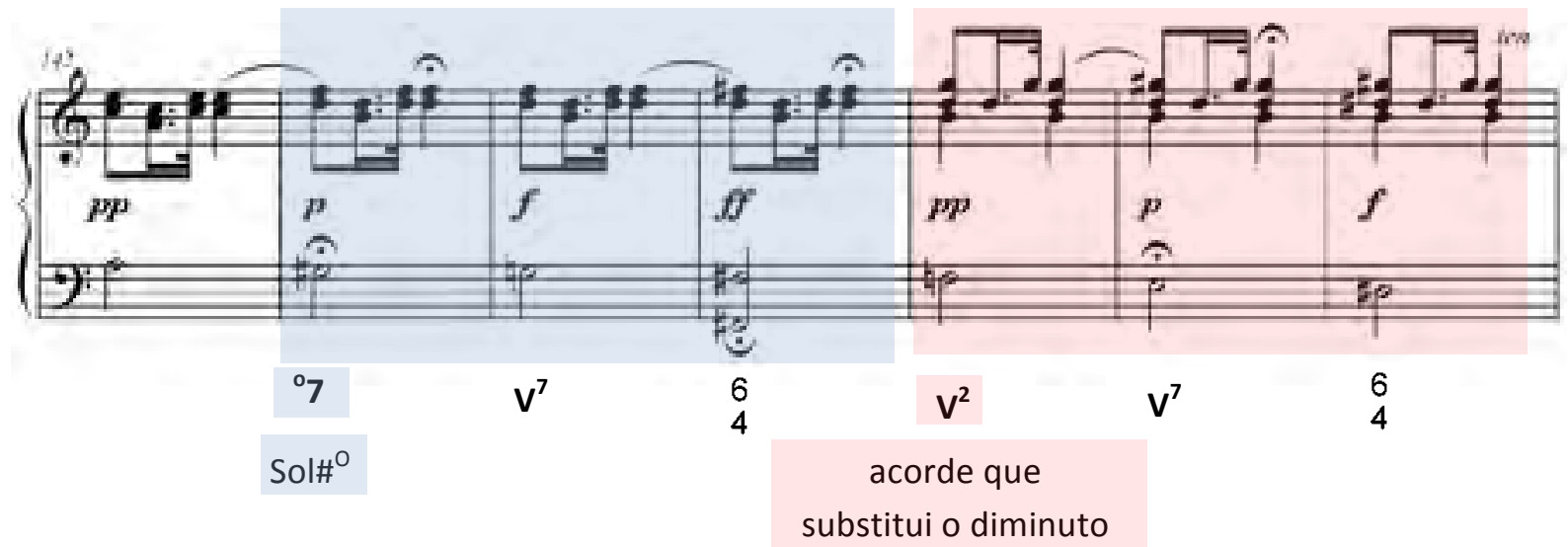




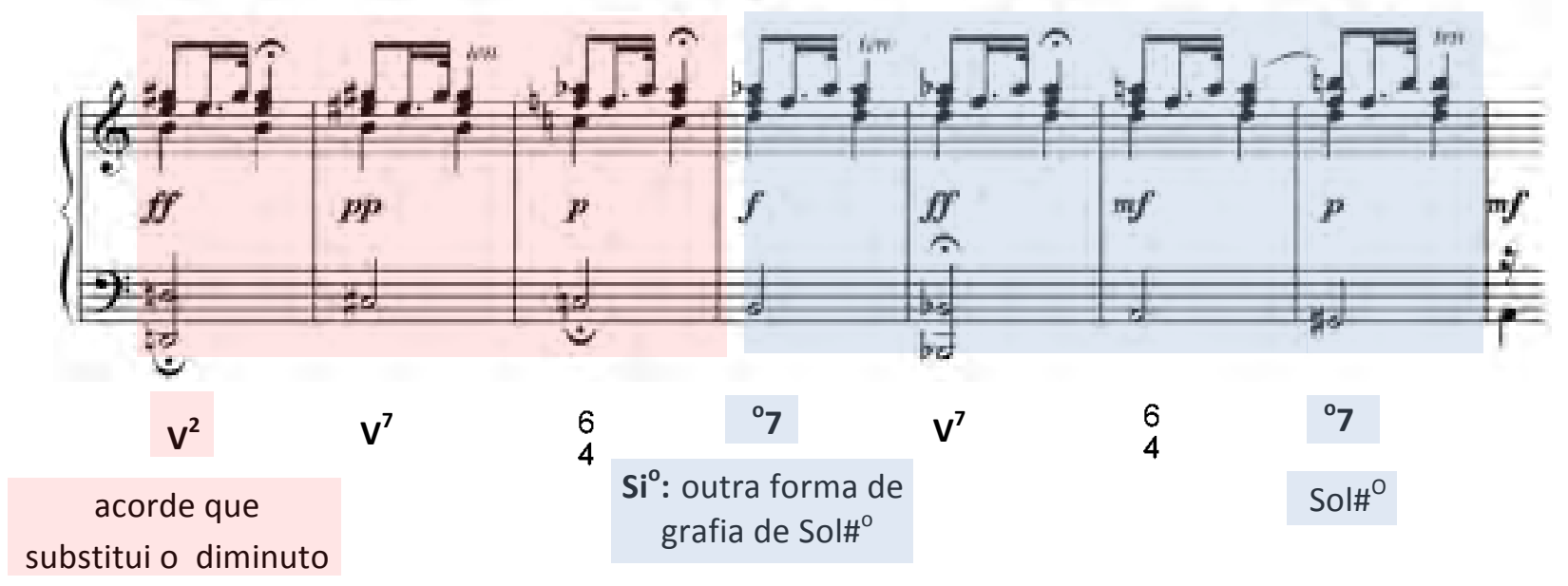

Redução:

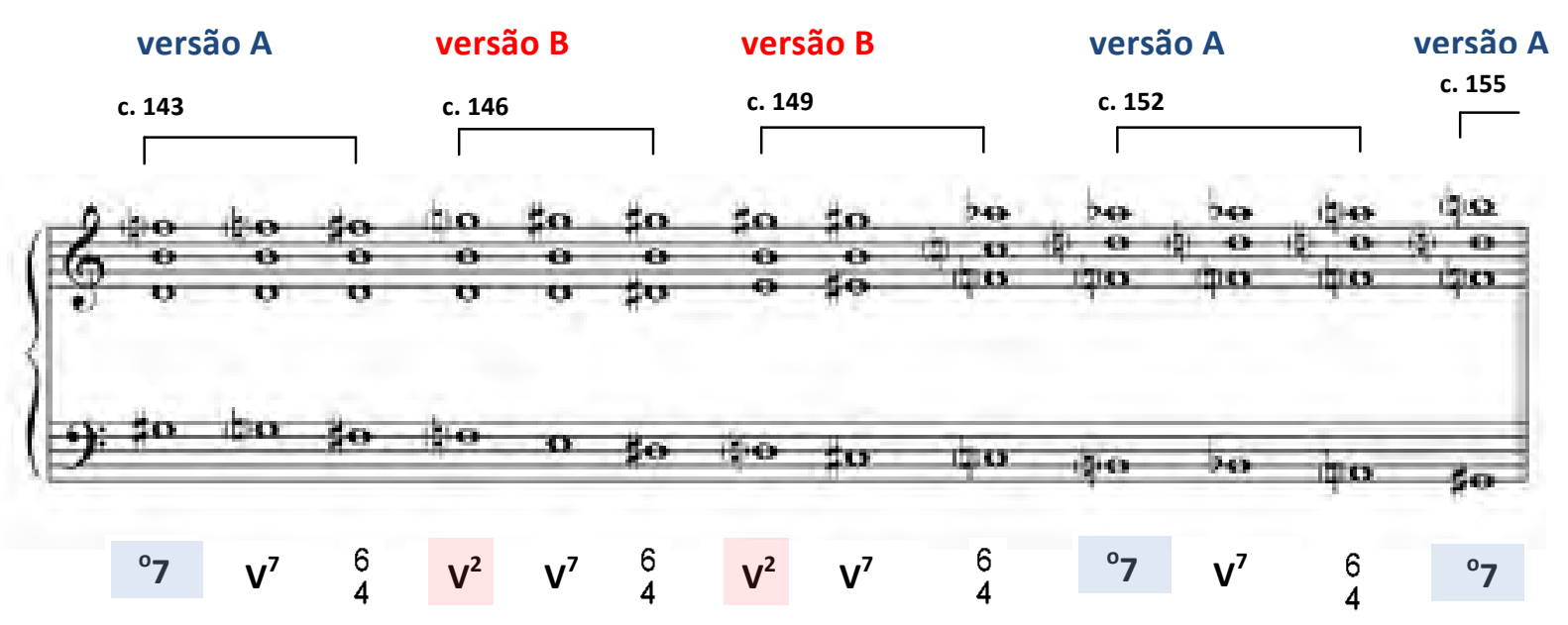

Paula Telesco observa que seria difícil subestimar o efeito que este rondó provocou no público da época, que provavelmente deve ter ficado perplexo com a novidade e ousadia harmônica da passagem (TELESCO, 1998, p. 270).

Ainda vinculado aos diferentes empregos das versões desta progressão cromática, um fator decisivo para o reconhecimento, compreensão da abrangência e diversidade inerente ao Teufelsmühle foi oferecido por Seidel:

O Teufelsmühle poderia também ter começado com um dos outros dois acordes, ou seja, com o acorde de sétima diminuta ou com o menor com quarta e sexta. Não haveria nada a se objetar a isso, se não houver mudanças no princípio de construção da seqüência dos acordes, isto é, se depois do acorde de sétima diminuta se seguir o acorde menor com quarta e sexta e, depois desse, o acorde de sétima de dominante, etc. [...] (SEIDEL, 1981, p. 173). 
Desta forma, enquanto estrutura cíclica, o Teufelsmühle conserva suas propriedades independentemente do acorde assumido como ponto de partida, como pode ser observado no Rondo no 3 de C. P. E. Bach (Ex. 11), em que a sequência se inicia com o acorde diminuto.

\section{3 - REINTERPRETAÇÃO ENARMÔNICA E O ACORDE DIMINUTO COM SÉTIMA DIMINUTA}

Um pequeno excurso a respeito da reinterpretação enarmônica torna-se necessário, uma vez que se trata de uma propriedade implícita e fundamental para o entendimento desta estrutura.

Cabe lembrar que a reinterpretação enarmônica é um aspecto estrutural inerente à tradição tonal e seu emprego por compositores pode estar associado à modulação, mudança de caráter, função formal, contraste motívico, de dinâmica, entre outros.

Algumas tipologias acórdicas já contêm esta possibilidade implícita em sua própria estrutura, tais como os acordes diminutos com sétima diminuta ${ }^{13}$ e a tríade aumentada, por serem estruturas simétricas e por esta razão apresentarem um número limitado de transposições ${ }^{14}$.

Pode-se observar a reinterpretação de um acorde diminuto no primeiro movimento do Trio KV 542 para piano, violino e violoncelo de Mozart (Ex. 12). O trecho em questão está na região de Dó menor e apresenta no compasso 222 o acorde de Si diminuto $\left(\right.$ vii $^{07}$ ) que, ao resolver no acorde de Lá menor no compasso 223, é reinterpretado como Sol\# diminuto $\left(\mathrm{vii}^{07} / \mathrm{iv}\right)$, uma dominante secundária para o retorno à tonalidade original de Mi maior.

\footnotetext{
${ }^{13}$ Telesco aponta que reinterpretações no acorde diminuto com sétima diminuta são formas muito comuns na música do século XVIII (TELESCO, 1998, p. 244).

${ }^{14}$ Dentre autores que abordam e desenvolvem este assunto destacam-se Schoenberg, em seu Tratado de Harmonia sob a designação de acordes errantes naturais, e Messiaen, em The Technique of my Musical Language sob o título de "modos de transposições limitadas".
} 

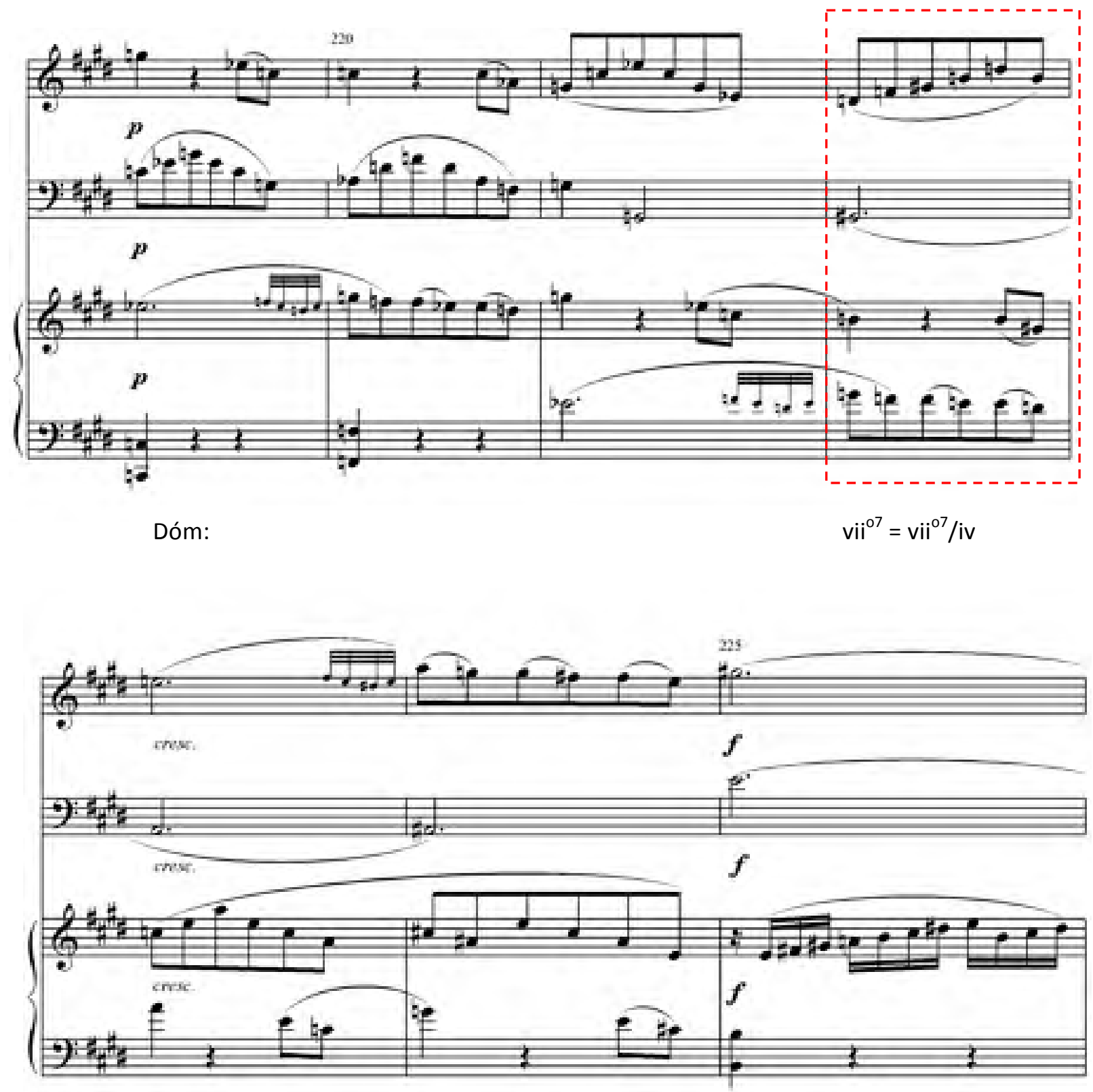

MiM: iv

Nesta perspectiva, cabe ressaltar que algumas outras tipologias também permitem esta propriedade, como é o caso da dominante com sétima, que pode ser interpretada como um acorde de sexta germânica e vice-versa. O exemplo seguinte apresenta um trecho da Terceira Sonata Op. 23 para piano de Scriabin, que compreende o final da exposição e abertura do desenvolvimento. Nesta passagem, o acorde classificado como dominante secundária no tom de LáM (V $\left.V^{7} / \mathrm{IV}\right)$ é reinterpretado como sexta germânica $\left(\mathrm{Ger}^{+6}\right)$ de Dó\#m, tonalidade que inicia o desenvolvimento. 

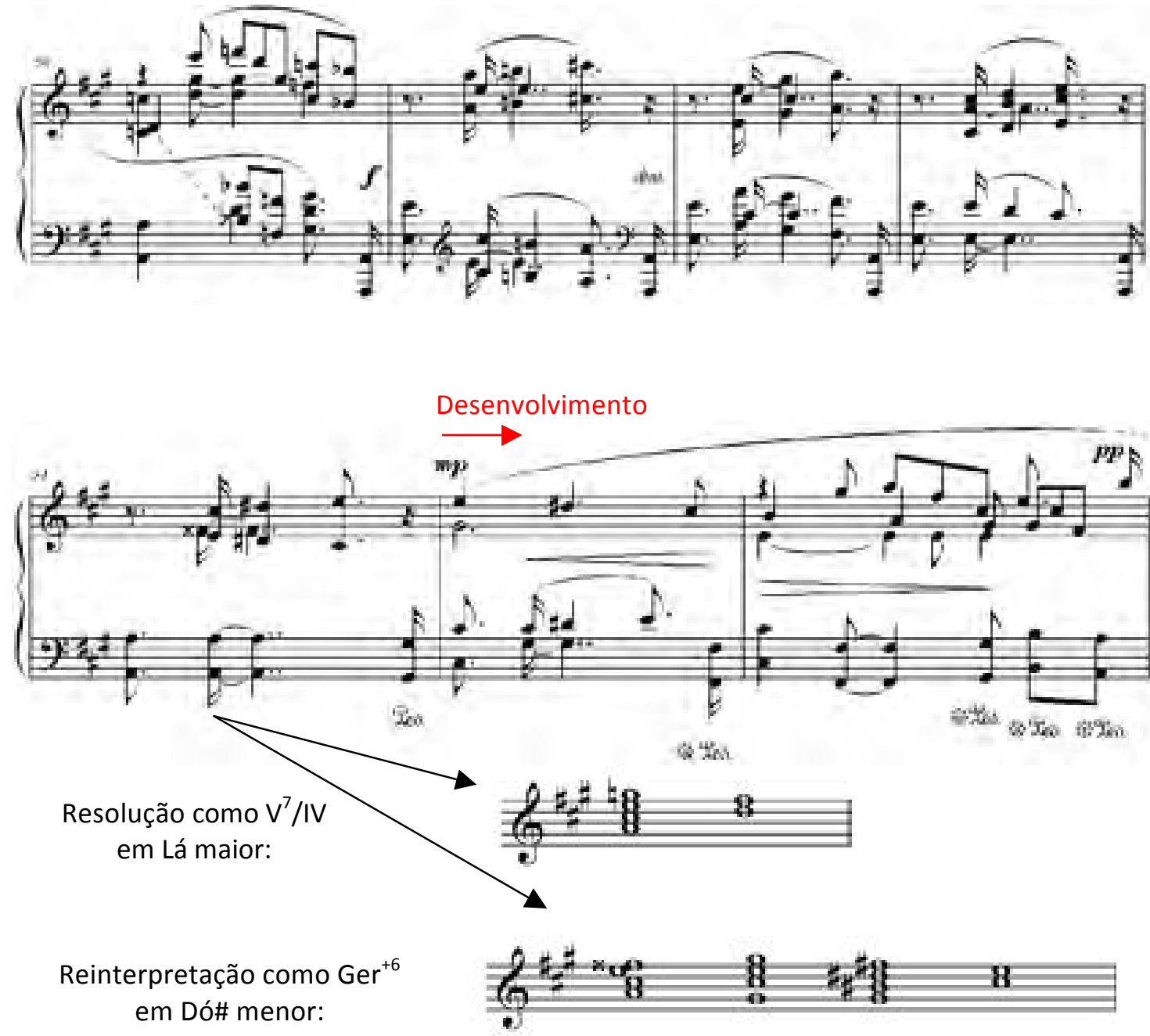

Observa-se neste caso que a reinterpretação enarmônica está vinculada à modulação entre Lá maior e Dó\# menor, bem como a uma troca de caráter, que é enfatizada pela indicação de dinâmica, o $\mathrm{mp}$ no compasso 55. Além disso, desempenha uma função formal importante, uma vez que marca a passagem da exposição para o desenvolvimento.

No caso do Teufelsmühle, a reinterpretação enarmônica do acorde dominante em um de sexta aumentada pode ser encontrada na descida do baixo cromático do modelo de Vogler, conferir exemplo 3. No segundo tempo do quarto compasso o acorde de Dó maior com sétima menor $\left(\mathrm{V}^{7}\right)$ aparece reinterpretado como acorde de sexta aumentada $\left(\mathrm{Ger}^{+6}\right)$. A seguir, o exemplo 14 apresenta uma redução deste padrão do Vogler (versão A), com os acordes de dominante com sétima escritos entre parênteses, seguidos por sua grafia como $\mathrm{Ger}^{+6}$. 
Exemplo 14 - Redução da harmonização de Vogler: baixo cromático descendente

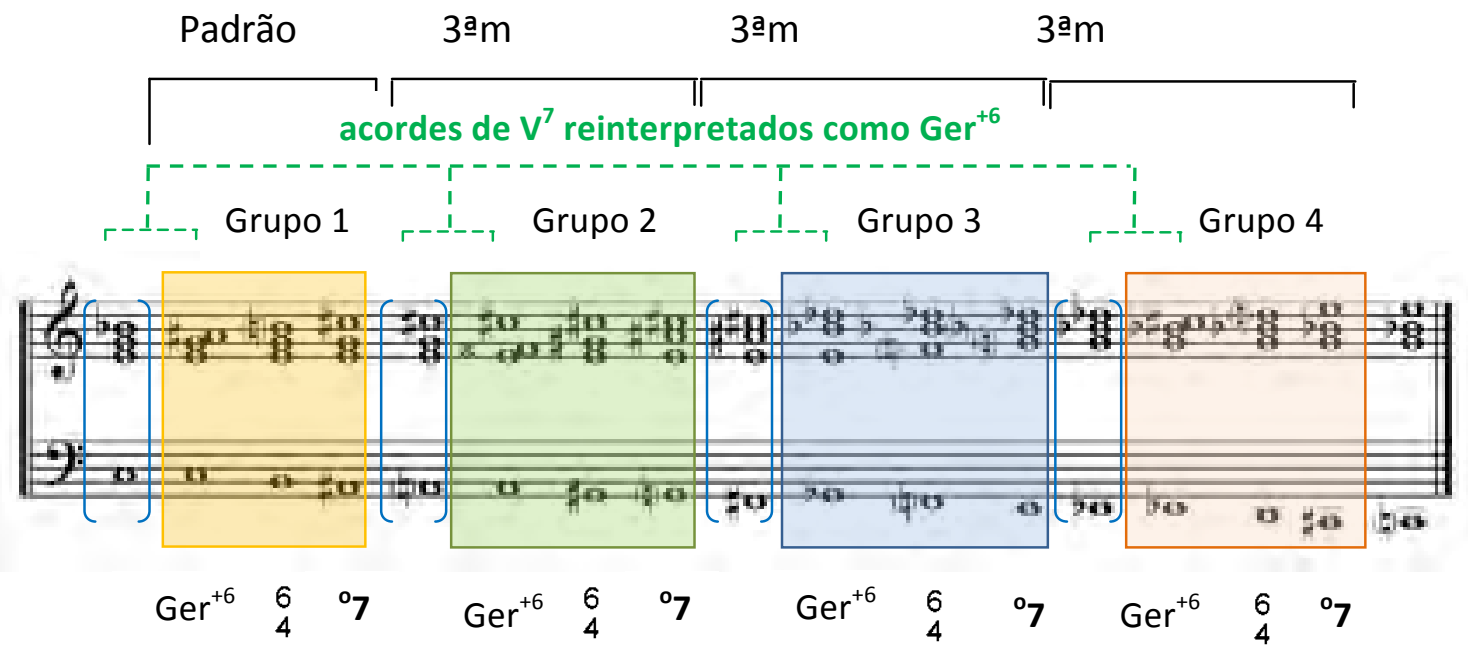

Na versão B do Teufelsmühe a reinterpretação enarmônica está implícita na própria estrutura, uma vez que o acorde de dominante com sétima (10 acorde do Ex. 15) é reinterpretado como $\mathrm{Ger}^{+6}$. Cabe lembrar também, que a dominante com a sétima no baixo (último acorde do exemplo), que substitui o acorde diminuto da versão $A$, também possibilita ser reinterpretado como $\mathrm{Ger}^{+6}$. Além disso, pode-se constatar a equivalência enarmônica entre o 1ㅇ e o 3ㅇa acordes, assim como a troca de vozes existente entre eles.

\section{Exemplo 15 - Teufelsmühle versão B: troca de vozes e reinterpretação enarmônica}

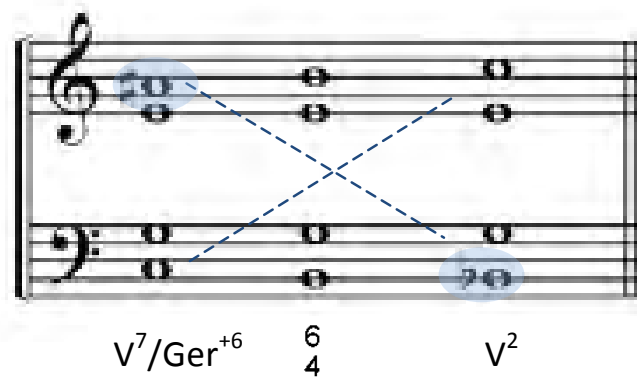

Desta forma, o Teufelsmühle tem uma capacidade inerente em se transformar, uma vez que suas tipologias prolongam a sensação de possíveis dominantes que, por meio de reinterpretações enarmônicas podem se direcionar para qualquer lugar, a qualquer instante, rompendo assim com a instabilidade harmônica gerada por sua própria natureza e estabilizar por meio de uma cadência. 
Uma evidência desta propriedade pode ser comprovada no exemplo 16, extraído do Rondo Op. 73 de Chopin, em que o Teufelsmühle (comps. 213 - 216) é utilizado com o propósito de modular da tonalidade de Dó maior para Mib maior. A versão $A$, composta por quatro acordes: dominante com sétima, diminuto, acorde menor com quarta e sexta e dominante com sétima, está empregada numa passagem de transição para a volta da Parte $A$, em Mib maior.

Exemplo 16 - Chopin: Rondo Op. 73, comps. $205-218$

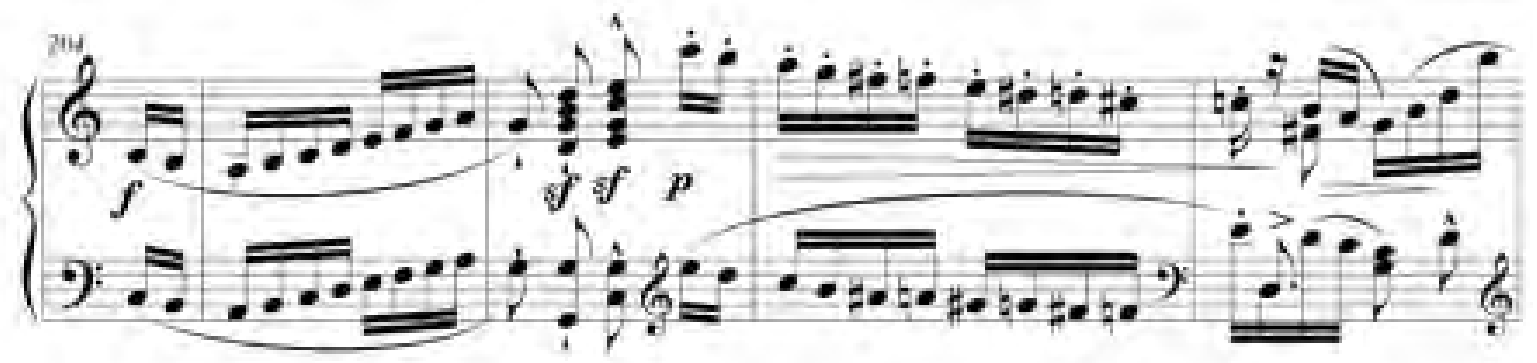

Teufelsmühle versão A

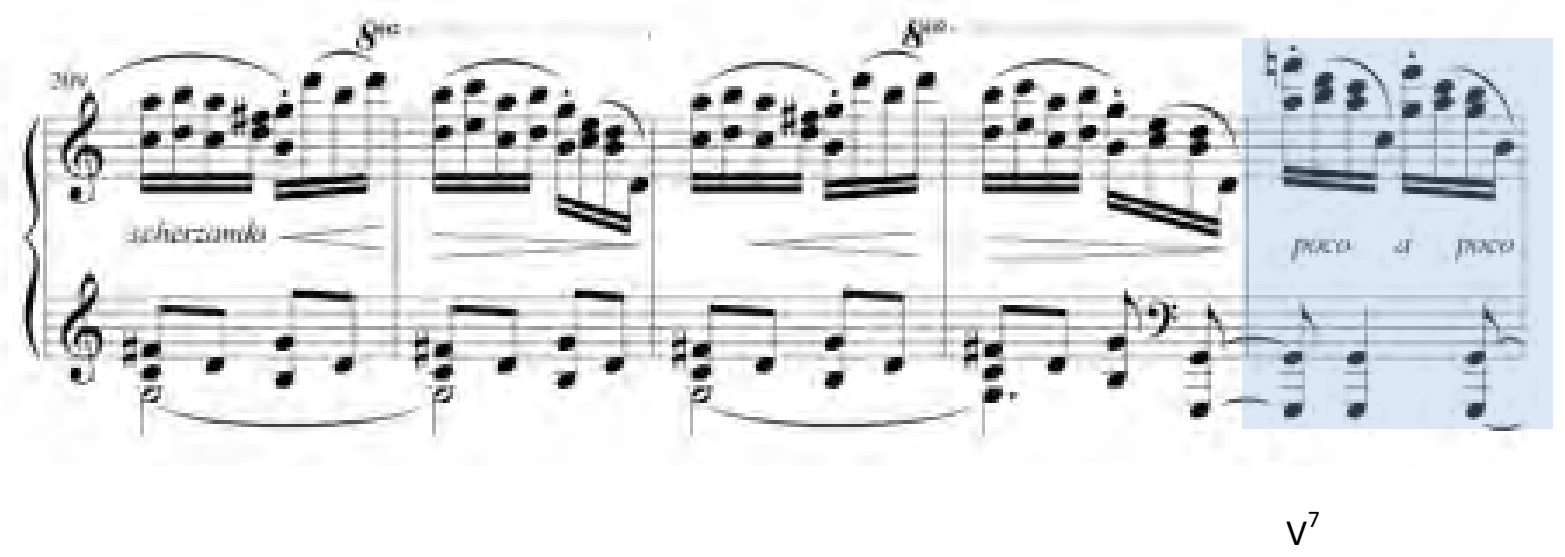

Parte A

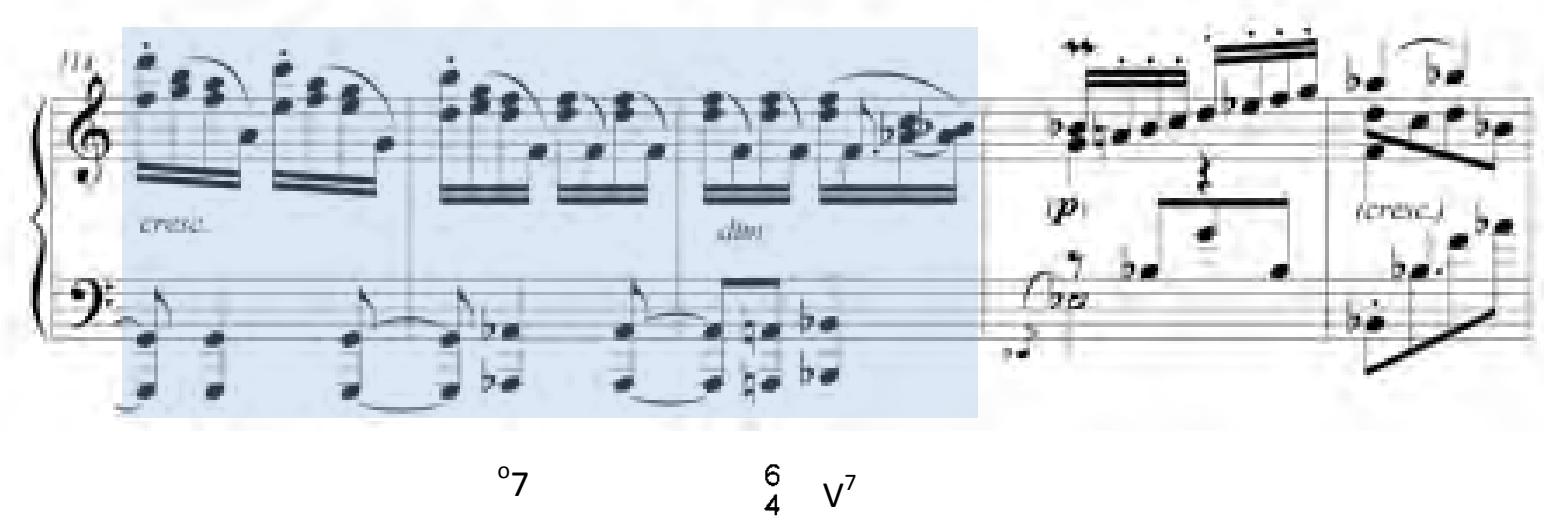




\section{Redução: Teufelsmühle versão A}

c. 213

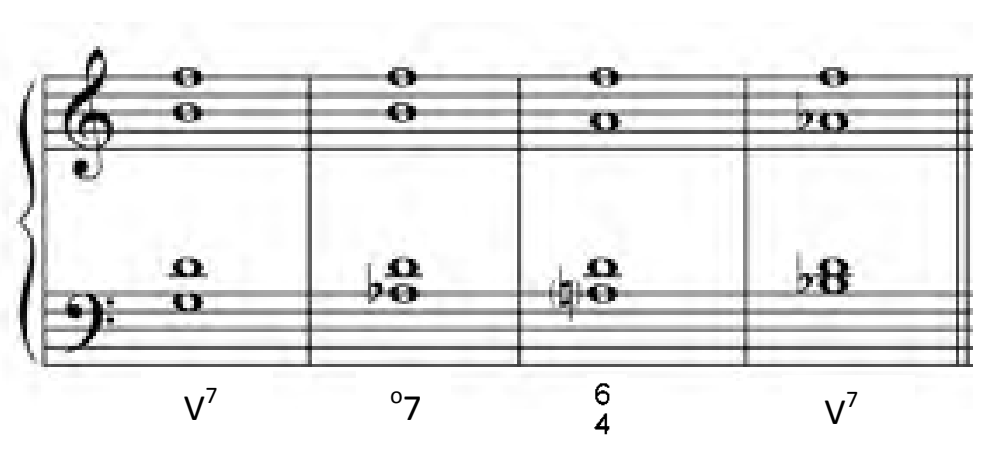

Feita a exposição acerca da reinterpretação enarmônica e da possibilidade latente de modulação do Teufelsmühle, é possível refletir, uma vez mais, sobre o princípio gerador da versão A: o acorde diminuto com sétima diminuta. O estudo da harmonização da escala cromática de Vogler permite também observar a expansão de um mesmo diminuto ${ }^{15}$, que no exemplo 17 está grafado de quatro formas diferentes.

\section{Exemplo 17 - 0 modelo de Vogler: relação de simetria e troca de vozes sobre o mesmo} acorde diminuto com sétima diminuta

acorde diminuto gerador e suas quatro possibilidades de apresentação

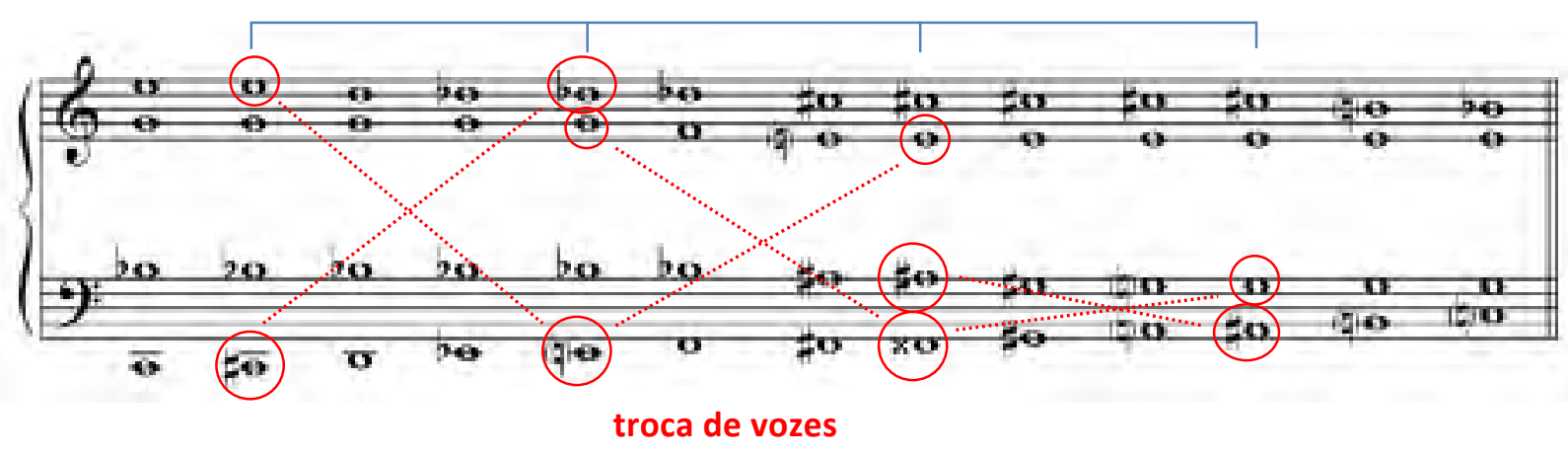

Assim, uma vez que o Teufelsmühle estrutura-se sobre o acorde diminuto e só existem três possibilidades diferenciadas desta tipologia, esta progressão também se encontra limitada à apenas três apresentações diferentes, ou seja, um modelo e mais duas transposições, como pode ser visto no exemplo $18^{16}$.

\footnotetext{
${ }^{15}$ Wason refere-se à harmonização da escala de Vogler como um "composing-out" de um acorde diminuto (1985, p. 19). Entretanto, o autor não esclarece de que forma isto ocorre.

${ }^{16}$ Estas transposições são também expostas por Dittrich em um quadro que a autora elabora para incorporar as visões do Teufelsmühle e do omnibus, assim como para utilizar em suas análises musicais (2007, p. 111).
} 


\section{Exemplo 18 - As transposições do Teufelsmühle}

a) Primeira apresentação do Teufelsmühle: acorde diminuto gerador, Dó\# diminuto

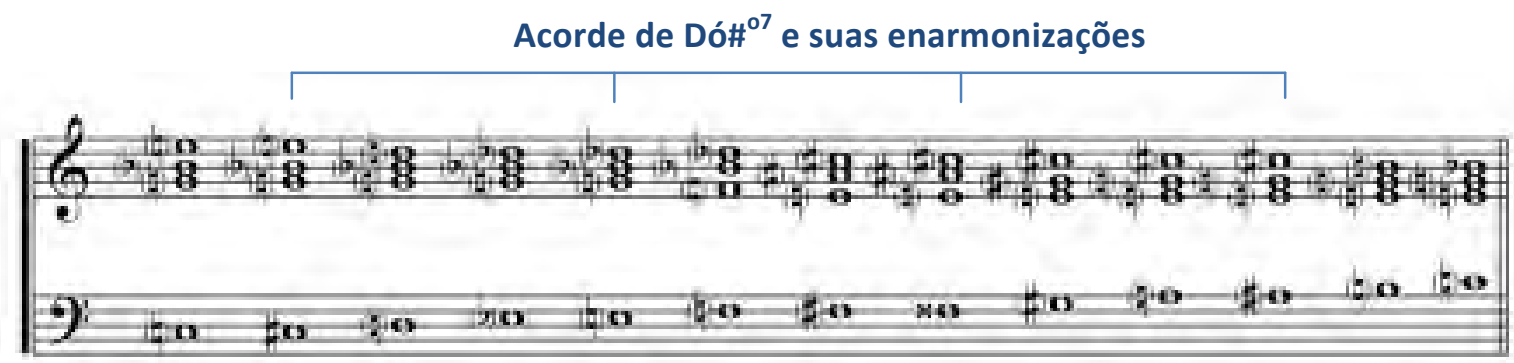

b) Segunda apresentação do Teufelsmühle: acorde diminuto gerador, Si\# diminuto (Dó diminuto)

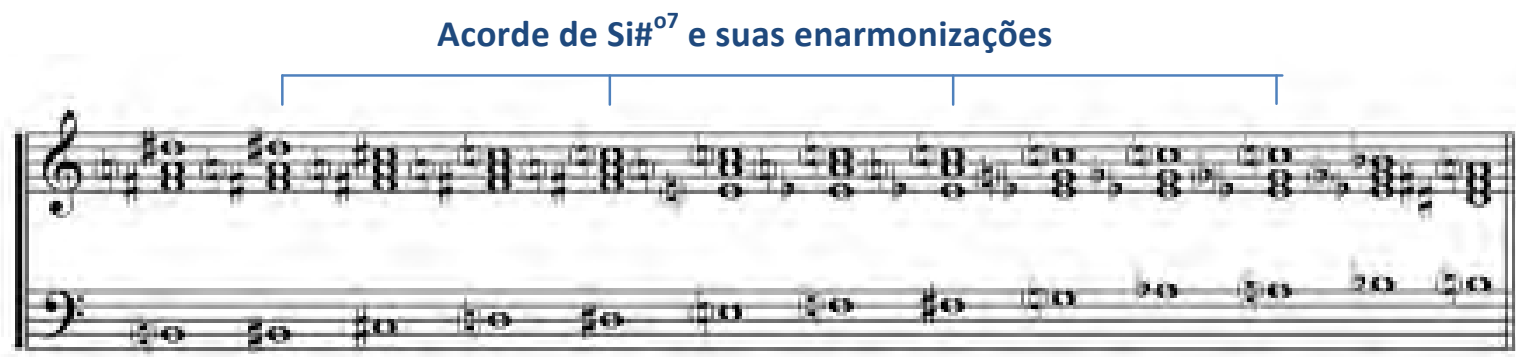

c) Terceira apresentação do Teufelsmühle: acorde diminuto gerador, Si diminuto

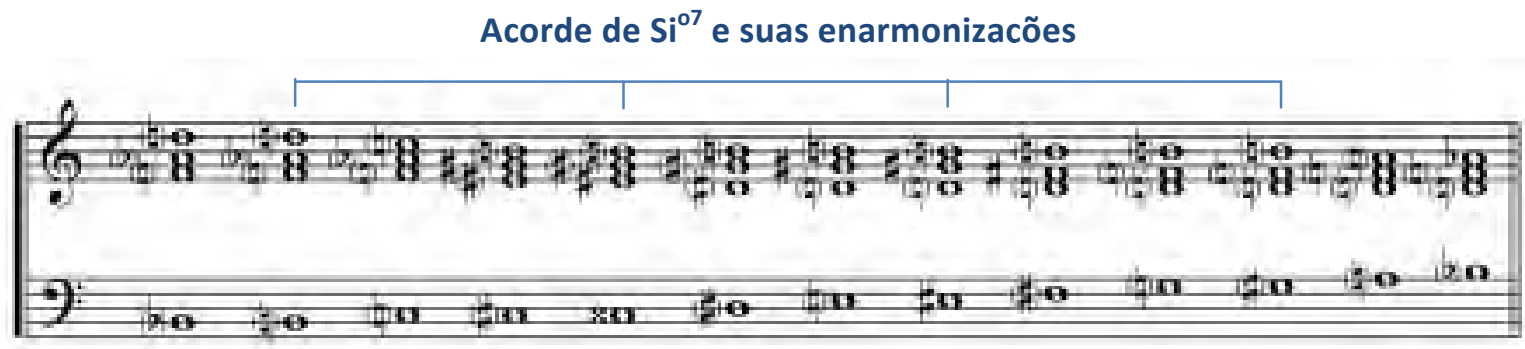

A importância de mostrar as três transposições está vinculada à forma e frequência com que o Teufelsmühle aparece no repertório. Assim, esta explanação objetiva facilitar o reconhecimento da progressão na literatura musical, uma vez que pode ser encontrada na íntegra, parcialmente e com transposições.

Uma análise do Noturno Op. 9 no 3 de Chopin permite constatar o emprego de diferentes transposições de fragmentos do Teufelsmühle. A primeira apresentação (comps. 107 - 108), partindo de Dó\# diminuto como acorde gerador, constitui a versão A com as seguintes tipologias: diminuto; menor com quarta e sexta; e dominante com sétima. Já a 
segunda aparição representa a versão B, gerada a partir do acorde de Dó diminuto, entre os compassos 112 - 113, com as seguintes tipologias: dominante com sétima no baixo; menor com quarta e sexta; e dominante com sétima (Ex. 19).

Ainda sobre este exemplo, a observação da partitura e da redução permite identificar que Chopin faz uso do Teufelsmühle como parte de uma sequência mais ampla, transposta quase que inteiramente em relação de segunda maior acima ${ }^{17}$, em que os compassos 106 111 correspondem aos compassos $112-117$.

Exemplo 19 - Chopin: Noturno Op. 9 no 3, comps. 105 - 116

Teufelsmühle versão A
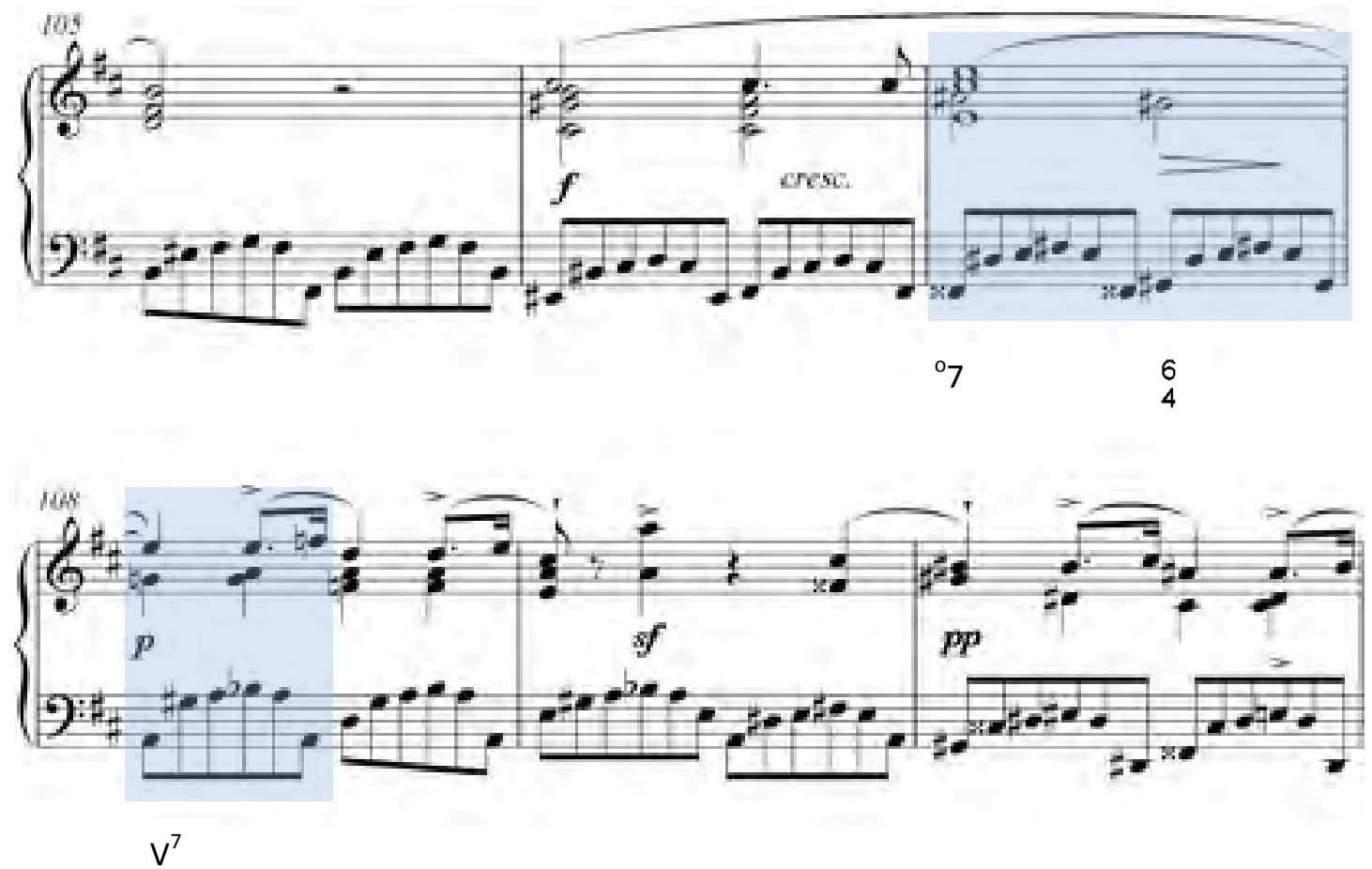

Teufelsmühle versão B

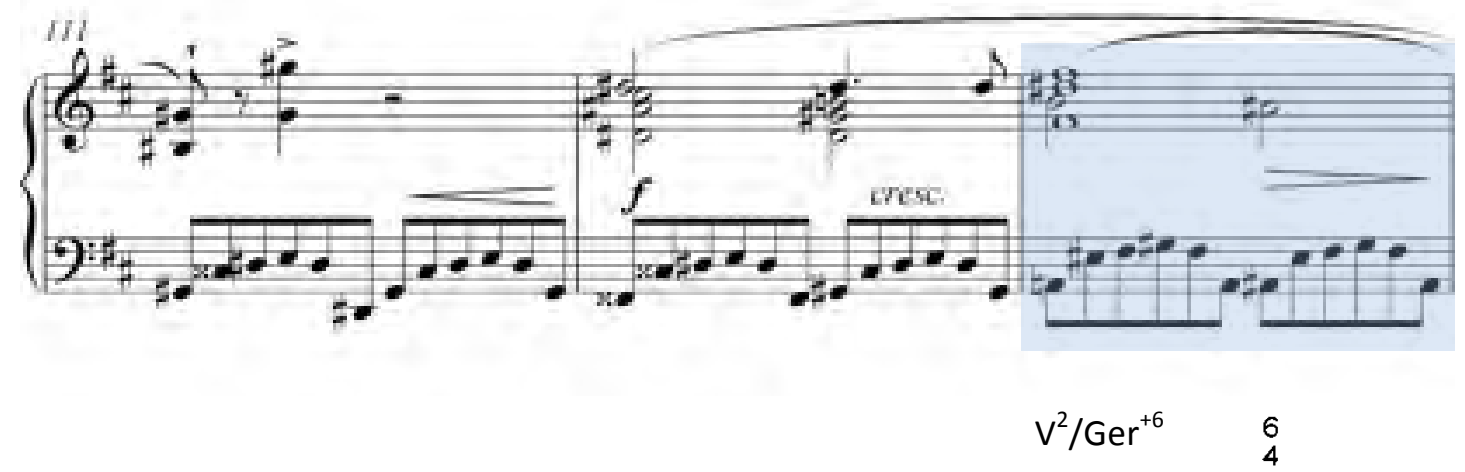

${ }^{17}$ Apenas a nota Si, primeiro tempo do compasso 113 , não se encontra num intervalo de $2^{a}$ maior acima em relação ao Lá\# do compasso 103. Isto se deve pela troca de versões do Teufelsmühle. 


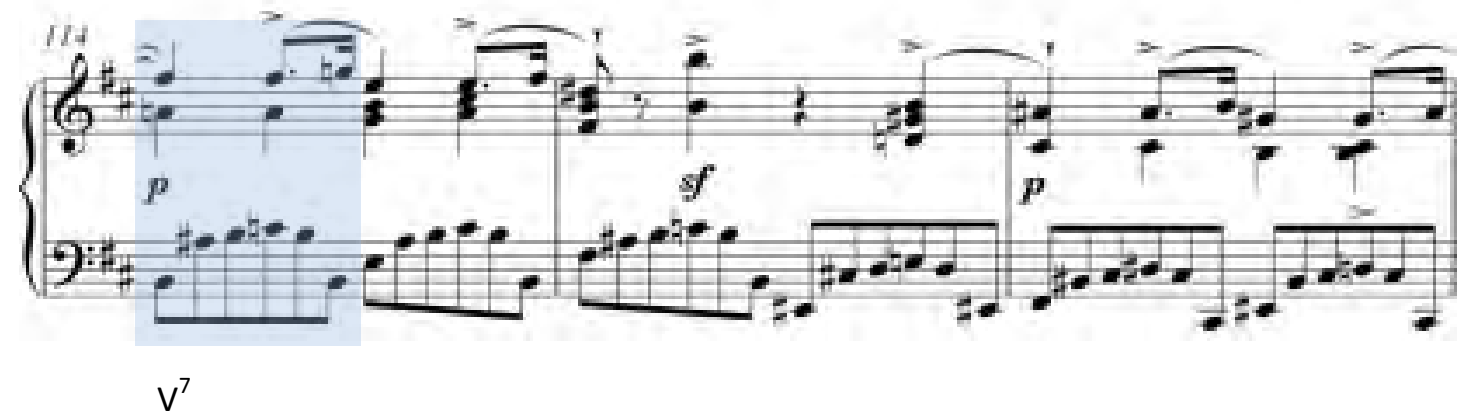

\section{Redução:}

\section{Teufelsmühle versão A}

c. 107

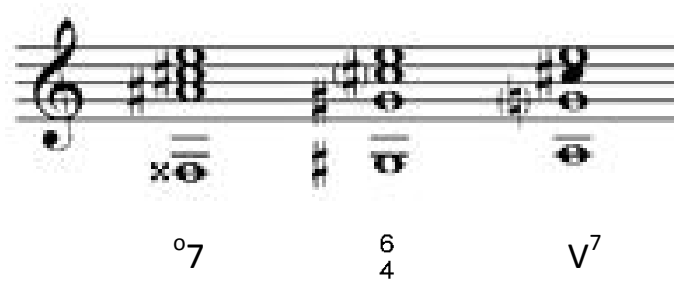

Teufelsmühle versão B
C. 114

c. 113

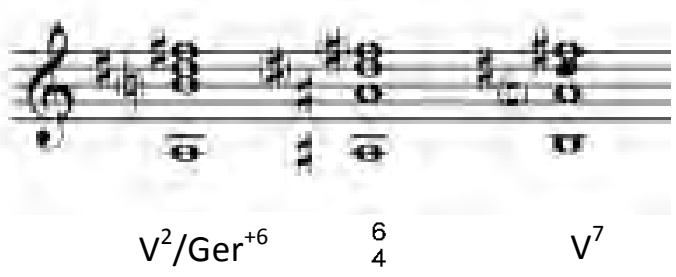

Aqui, no entanto, a passagem possui pequenas variantes do modelo de Vogler, a partir destas reduções é possível observar que tanto o primeiro quanto o segundo fragmento (versão A e B) omitem uma nota de seus respectivos acordes de dominante com sétima, como indicado com a notação da semínima sem haste.

Outros aspectos pertinentes às propriedades do Teufelsmühle referem-se ao seu vínculo com o segundo modo de transposição limitada de Messiaen e seu emprego com funções motívicas ou melódicas derivadas da escala octatônica, como demonstra Seidel no artigo de 1981. A forma com a qual o autor aborda trechos em Liszt e Chopin relaciona aspectos harmônicos, melódicos e motívicos capazes de oferecer elementos para uma compreensão estrutural mais ampla. Entretanto, são necessárias algumas reflexões e etapas preliminares para aclarar a relação anunciada por Seidel na citação a seguir:

Entre o Teufelsmühle versão A e o segundo modo, portanto, existe não apenas uma relação qualquer como supúnhamos, mas algo além: há [uma relação de] identidade [...] Dito de outra forma: ao ressoar o Teufelsmühle (sempre na versão A), ressoa ao mesmo tempo o segundo modo sobre o baixo cromático ascendente ou descendente (SEIDEL, 1981, p. 174).

A divisão da oitava em quatro partes iguais, eqüidistantes por terças menores, é uma propriedade inerente ao acorde diminuto com sétima diminuta e ao Teufelsmühle. Tal relação 
justifica a referência a Messiaen, à escala octatônica e ao segundo modo de transposição limitada feita por Seidel. Em sua explicação, retorna ao modelo de Förster e propõe a investigação do material sonoro dos acordes que compõe a progressão por meio da disposição linear de cada uma de suas vozes superiores ${ }^{18}$. O exemplo 20 reapresenta a harmonização de Förster, acompanhada pela proposta de Seidel sobre a obtenção da escala octatônica a partir do exame das linhas melódicas correspondentes às vozes de soprano, contralto e tenor. A linha do baixo não é considerada neste processo, por sua natureza exclusivamente cromática.

\section{Exemplo 20 - Modelo de Förster e a escala octatônica}

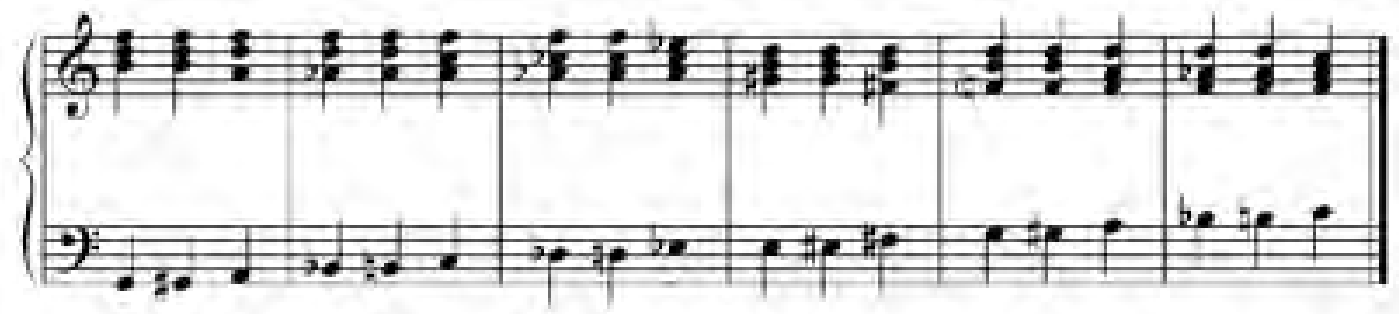

Disposição linear das vozes para a obtenção da escala octatônica:

soprano contralto tenor

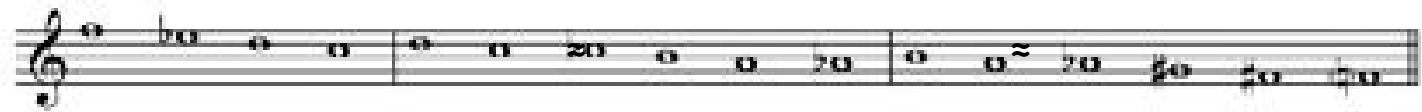

Escala octatônica resultante:

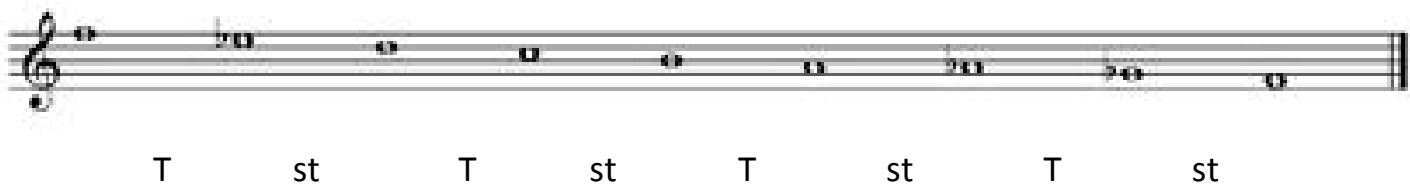

Seidel demonstrou este vínculo entre o Teufelsmühle versão A e a escala octatônica em duas aplicações analíticas: o Estudo Ab irato de Liszt, compassos 25 a 28 (Ex. 21), e o Estudo Op. 10 no 9 de Chopin, compassos 25 a 28 (Ex. 23).

\footnotetext{
${ }^{18}$ Para mais informações sobre este aspecto, cf. Seidel (1981, p. 174 e p. 184).
} 
Exemplo 21 - Liszt: Ab irato, comps. 25 - 30 (SEIDEL, 1981, p. 183)

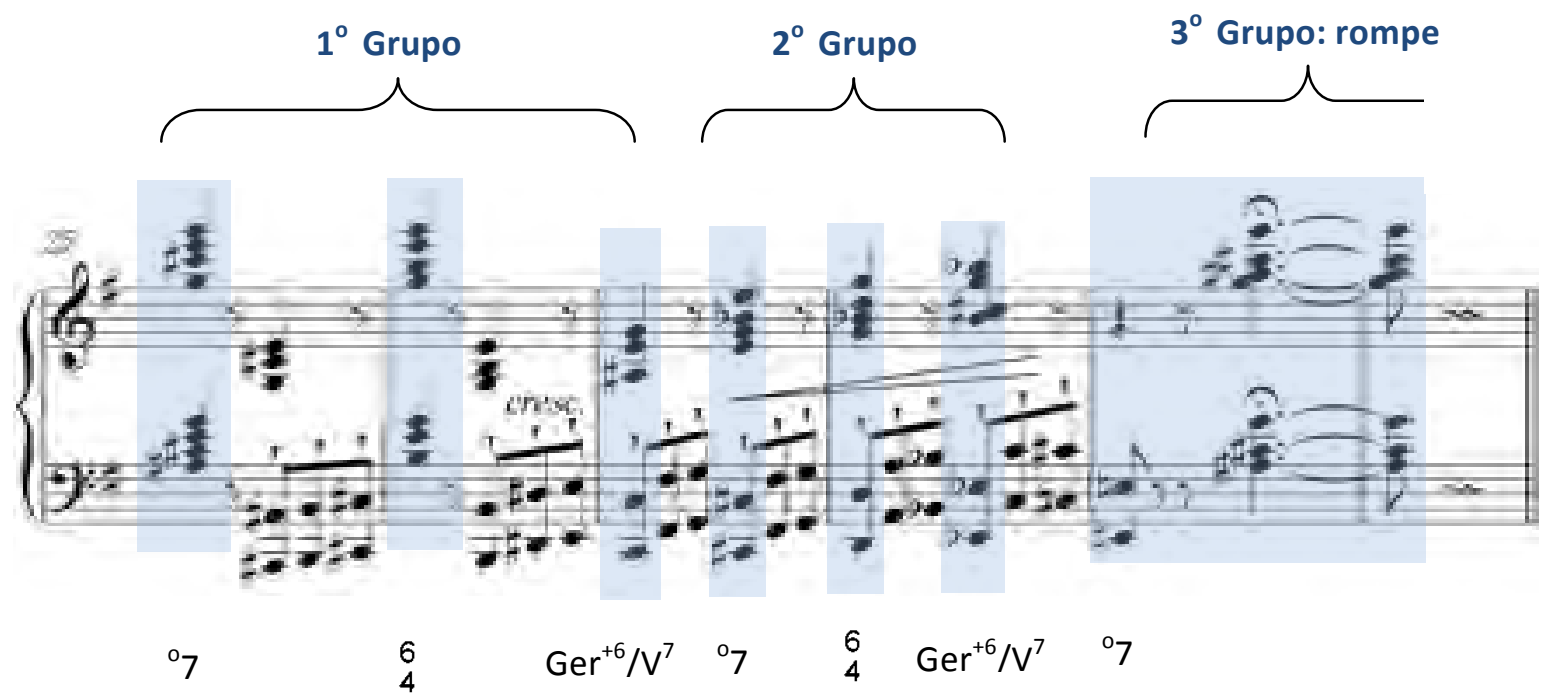

A respeito das tipologias deste exemplo, Seidel esclarece que:

[...] dois grupos do Teufelsmühle (versão A) constituem a estrutura harmônica dos primeiros quatro compassos de nosso exemplo (compassos 25 a 28). Cada grupo começa com um acorde de sétima diminuta. Segue-se um acorde menor com quarta e sexta. 0 terceiro acorde é, em ambos os casos, escrito como um acorde de sexta aumentada [...] Liszt poderia igualmente ter escrito [como] um acorde de sétima de dominante [...], tal como, diga-se de passagem, ele o fez em parte na passagem correspondente da primeira versão dessa peça. Um terceiro grupo do Teufelsmühle começa no compasso 29, mas depois do primeiro acorde, o acorde de sétima diminuta (Mi Lá\# Dó\# Sol), é interrompido (SEIDEL, 1981, p.173).

Ao continuar, analisa o material da figuração da mão esquerda e chega à conclusão que se trata da escala octatônica:

Por meio da figuração entram sons estranhos aos seis acordes do Teufelsmühle. Se ouvirmos mais atentamente, descobriremos que a quinta e sexta colcheias tocadas a partir do compasso 26 , assim como a segunda e a terceira colcheias da mão esquerda pertencem ao mesmo grupo. Elas constituem uma escala (Ex. 8). Trata-se de uma escala de um tipo especial, que contém não sete, mas oito sons. Nela falta a quinta justa, por isso o círculo de terças menores constitui a sua estrutura (SEIDEL, 1981, p. 174).

O exemplo a seguir retoma o trecho do Estudo Ab irato para aclarar a visão de Seidel sobre a figuração do baixo e a escala octatônica. Para tanto, passagens preliminares encontramse descritas no exemplo 22 para ilustrar o diminuto gerador grafado em três formas diferentes, as notas estranhas ao Teufelsmühle que aparecem como figuração melódica no baixo e, finalmente, a estrutura da escala octatônica resultante. 
Exemplo 22 - Escala octatônica no trecho do Ab irato de Liszt

Diminuto gerador: Lá\#

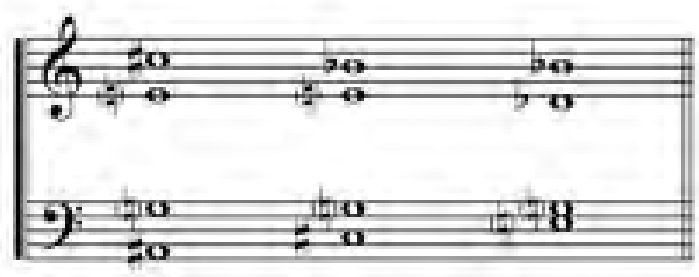

$A b$ irato, mão esquerda dos compassos 25 a 29, figuração e a octatônica

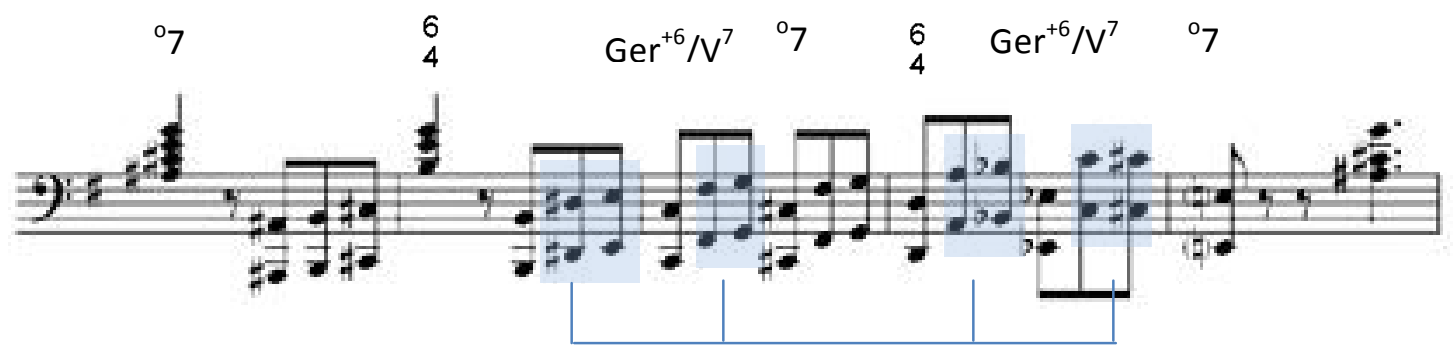

escala octatônica

Escala octatônica:

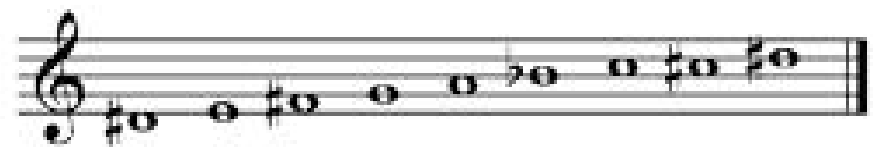

Ao prosseguir em seu artigo, Seidel compara o Ab irato de Liszt com o Estudo Op. 10 no 9 de Chopin para comprovar que se trata dos mesmos grupos de acordes do Teufelsmühle versão A e, mais uma vez, com o emprego da escala octatônica como figuração melódica (Ex. 23).

Exemplo 23 - Chopin: Estudo Op. 10 no 9, comps. 25 - 28 (SEIDEL, 1981, p. 184)

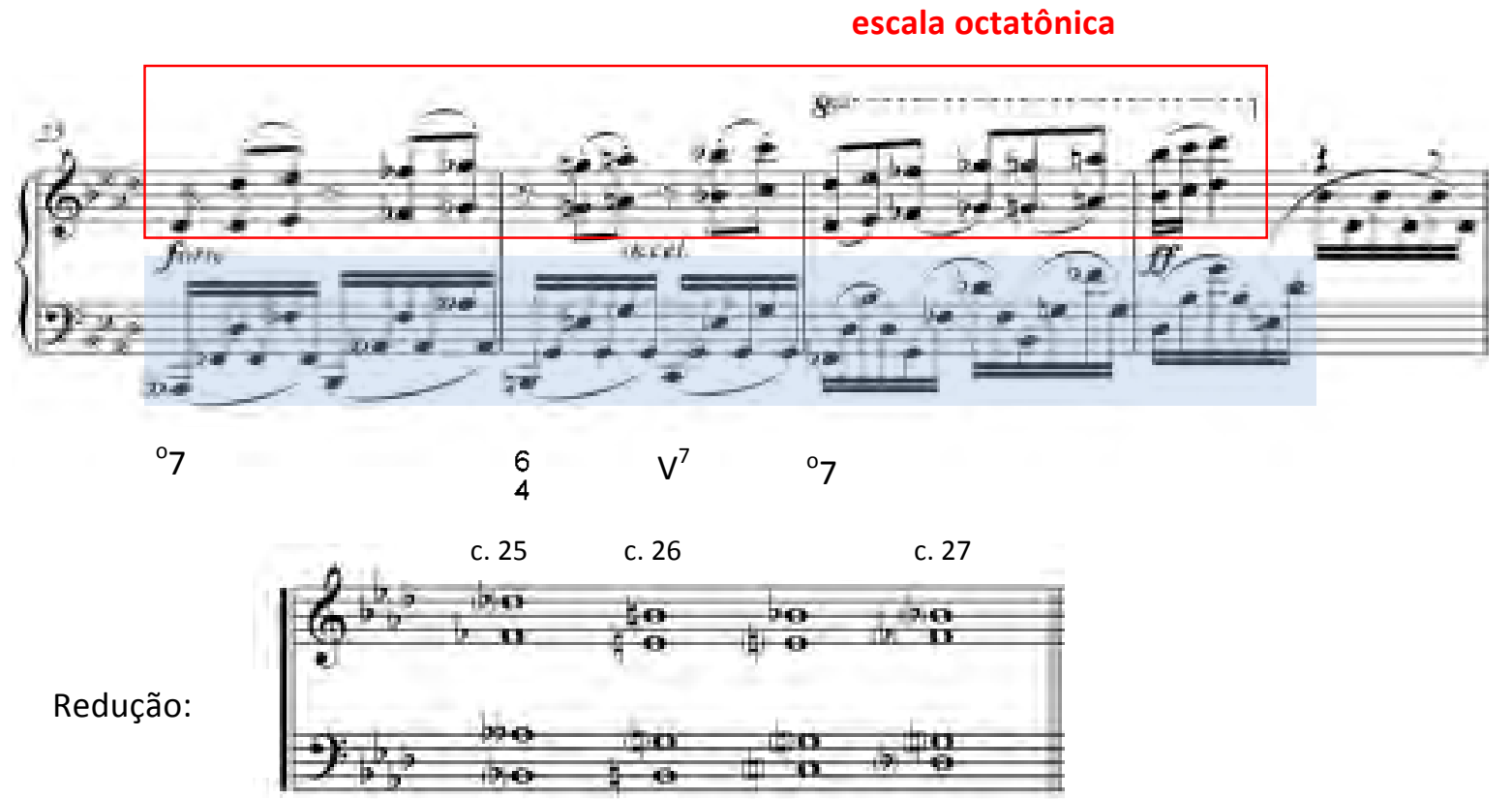

$\begin{array}{llll}{ }^{0} 7 & 6 & V^{7} & { }^{0} 7\end{array}$ 


\section{4 - VARIANTES DO TEUFELSMÜHLE}

As análises realizadas por Seidel contribuíram, a partir da constatação de modificações mais profundas nas diferentes versões do Teufelsmühle, com um ponto fundamental para o entendimento mais abrangente destas progressões: as variantes do Teufelsmühle.

Neste sentido, ao reconhecer as diversas possibilidades de variantes das sequências cromáticas, a pesquisadora Dittrich alerta que:

Outras formas desse modelo, que são mais difíceis de reconhecer, são derivadas da combinação - muito freqüente na prática composicional - das versões A e B do Teufelsmühle, bem como da modificação [do padrão], omissão de alguns acordes, ou saltos para uma das transposições (DITTRICH, 2007, p. 112).

Assim, a seguir serão expostas algumas formas de apresentação aplicadas à versão A, que incluem: a omissão do acorde de dominante com sétima; a substituição do acorde de dominante por um acorde maior com sexta acrescentada; e a substituição do acorde menor com quarta e sexta por acordes menores em estado fundamental. Para encerrar o capítulo, será também descrita e comentada a variante do Teufelsmühle aplicada à versão B.

\section{1 . 4 . 1 - Omissão do acorde de dominante com sétima}

Esta variante altera o padrão original (versão A), ao restringir cada grupo do Teufelsmühle apenas ao uso de duas tipologias diferentes: acorde diminuto e o acorde menor com quarta e sexta. Além disso, a omissão da dominante com sétima modifica o perfil da linha do baixo, que deixa de ser exclusivamente cromática.

O exemplo 24 permite observar as alterações da versão A e a identidade que esta variante conserva com o segundo modo de transposição limitada. No lugar do cromatismo, a linha do baixo deixa explícita a escala octatônica. Além disso, todas as demais notas das vozes superiores, se dispostas de forma linear (melódica), apresentam-se como partes constituintes desta escala e, portanto, mantém-se identificadas com a estrutura e a sonoridade do segundo modo de transposição limitada, cf. Seidel (1981, p. 175). 
Exemplo 24 - Versão A com omissão dos acordes de dominante com sétima

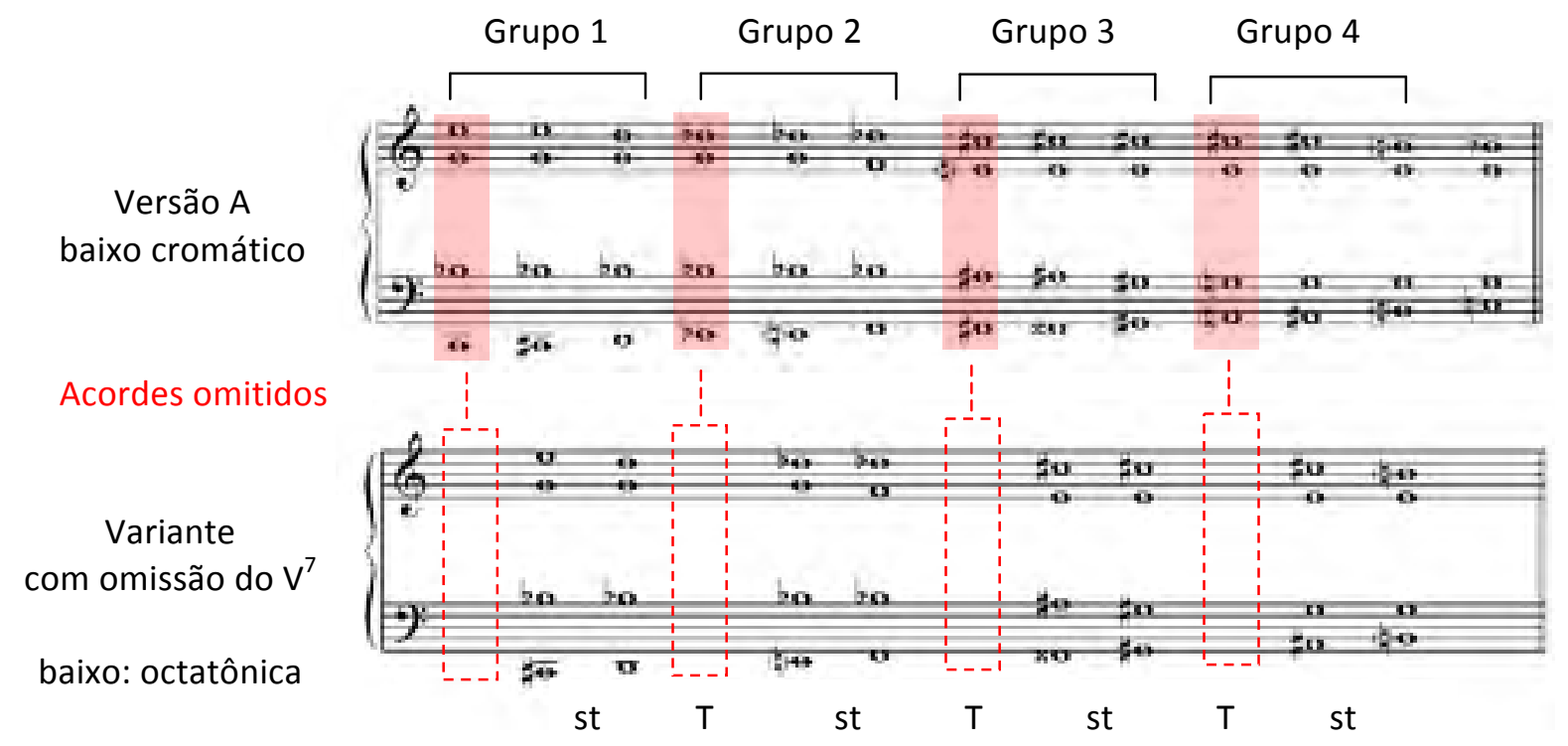

O exemplo a seguir ilustra um trecho do Segundo Estudo de Concerto para piano "La Leggerezza" de Liszt (comps. 38 - 40), em que o compositor emprega a variante do Teufelsmühle com a omissão dos acordes de dominante com sétima nos arpejos quebrados da mão esquerda (Ex. 25).

Exemplo 25 - Liszt: “La Leggerezza”, comps. 38 - 40 (SEIDEL, 1981, p. 185)

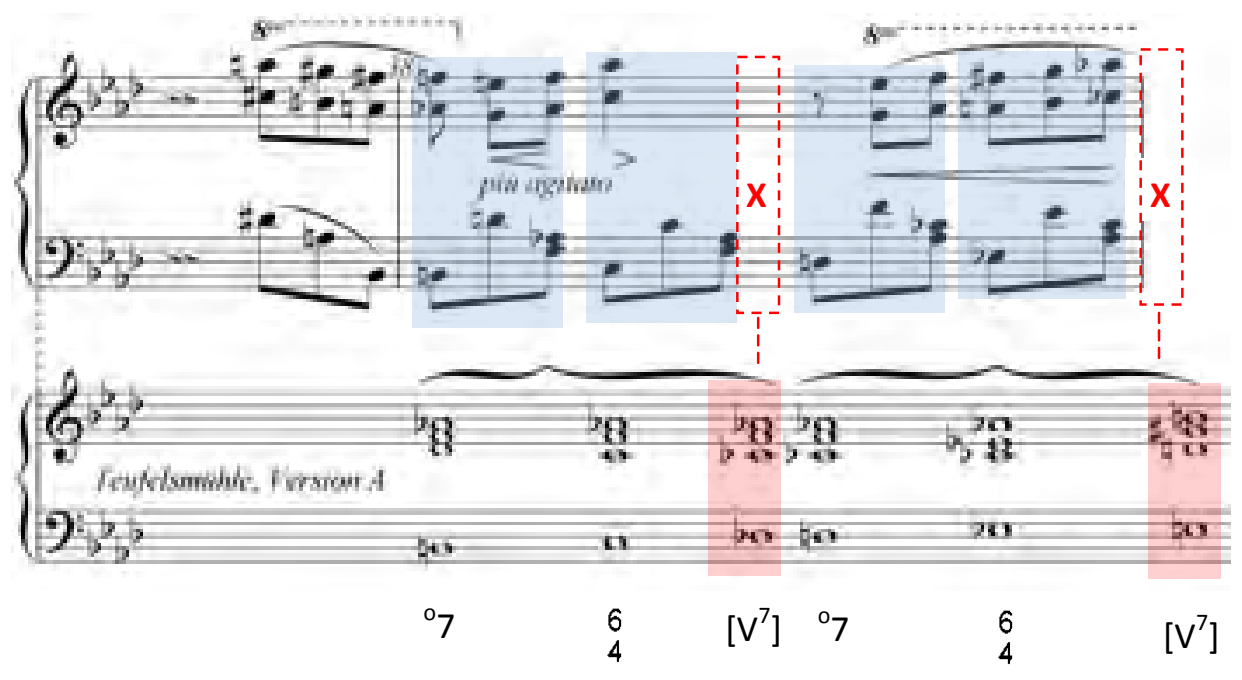




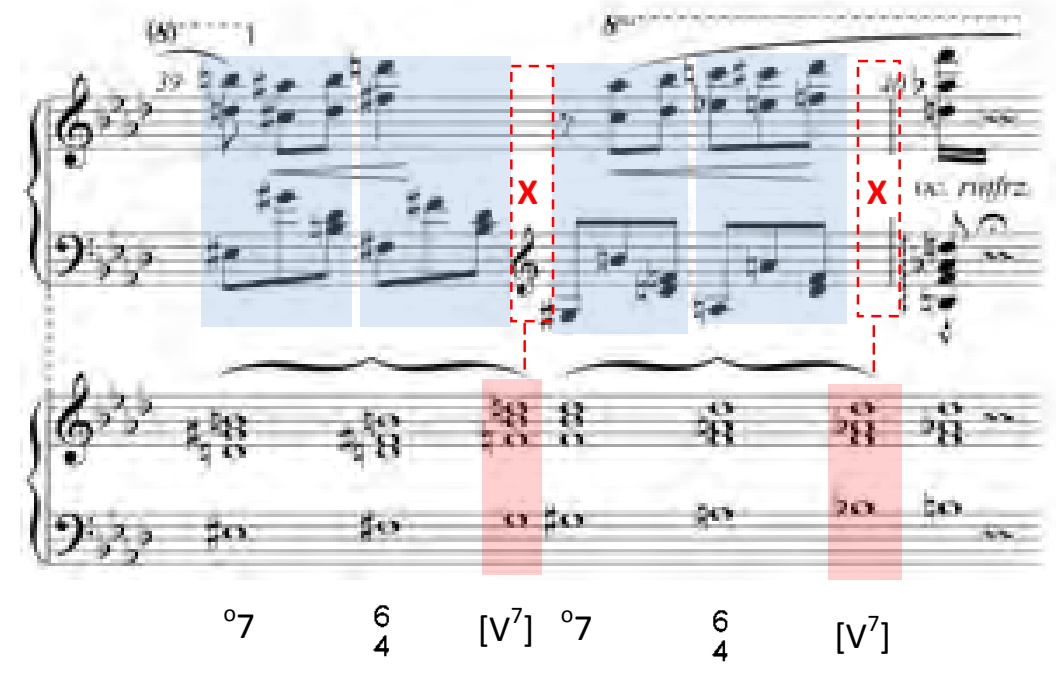

\section{1 . 4 . 2 - Substituição do acorde de dominante com sétima}

Outra variante da versão A do Teufelsmühle listada por Seidel é a substituição do acorde de dominante com sétima por um acorde maior com sexta acrescentada. Tal possibilidade encontra-se também exemplificada em "La Leggerezza" de Liszt, mas desta vez entre os compassos 67 e 68 (Ex. 26).

Exemplo 26 - Liszt: “La Leggerezza”, comps. 67 - 68 (SEIDEL, 1981, p. 186)

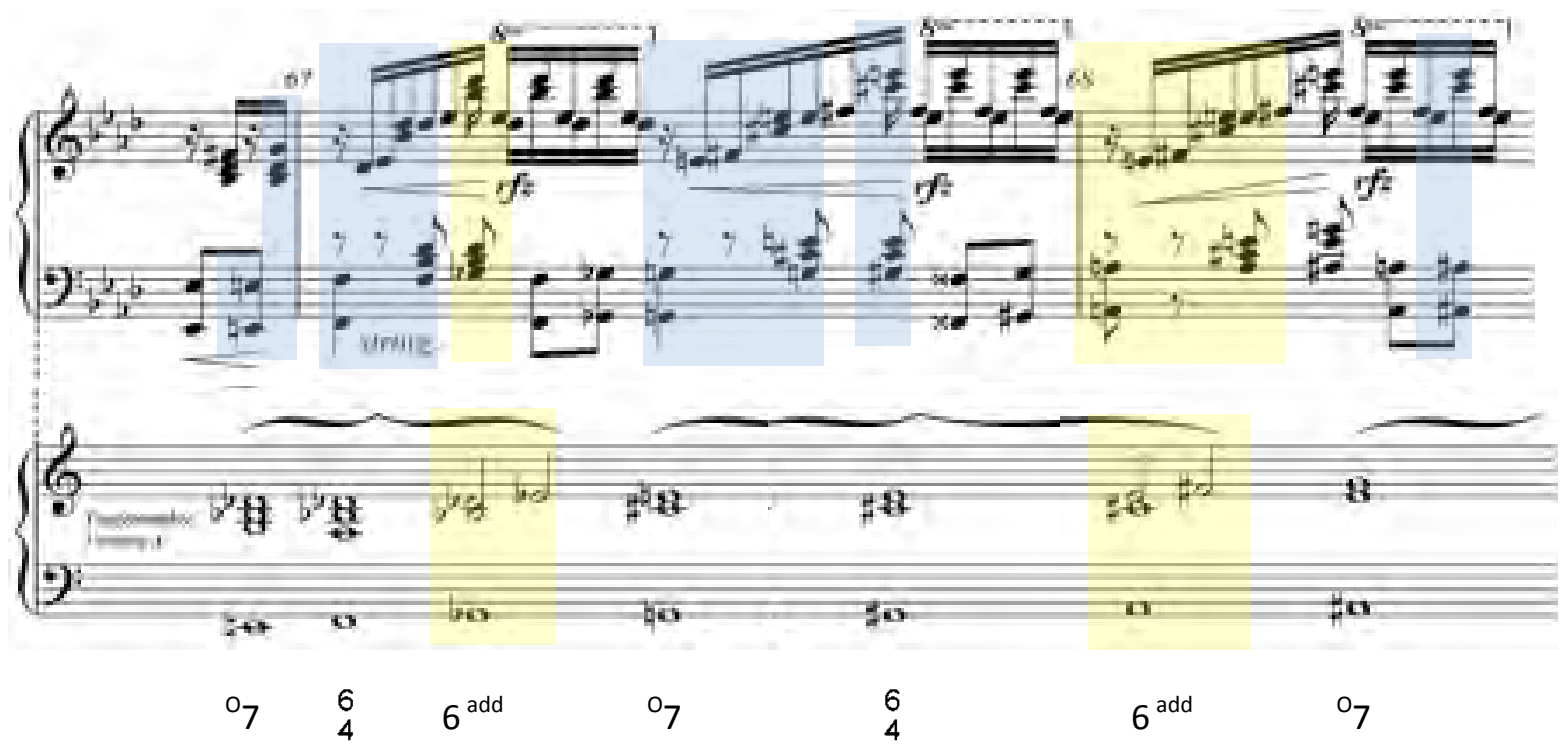




\section{1 . 4 . 3 - Substituição do acorde menor com quarta e sexta}

A substituição do acorde menor com quarta e sexta por tríades menores em estado fundamental foi considerada por Seidel como uma variante do Teufelsmühle, uma vez que conserva a sonoridade do padrão original, além de sua conexão com o segundo modo de transposição limitada.

Na Sonata Dante de Liszt, no trecho entre os compassos 89 a 95 (Ex. 27), ocorre omissão do acorde de dominante com sétima, além da substituição do acorde menor com quarta e sexta por uma tríade menor em estado fundamental. Sobre este exemplo Seidel comenta:

Um episódio da chamada Sonata Dante (Après une lecture de Dante, Anos de Peregrinação II, 2a versão 1849, compassos 89 -95) é construído de maneira harmonicamente similar à passagem dos compassos 38 - 40 do [Segundo] Estudo. Mas aqui, os acordes menores com quarta e sexta foram intercambiados por tríades menores na posição fundamental. [...] inclusive a parte da mão direita está no segundo modo [...](SEIDEL, 1981, p. 175).

Exemplo 27 - Liszt: Sonata Dante, comps. 89 - 95 (SEIDEL, 1981, p. 187)

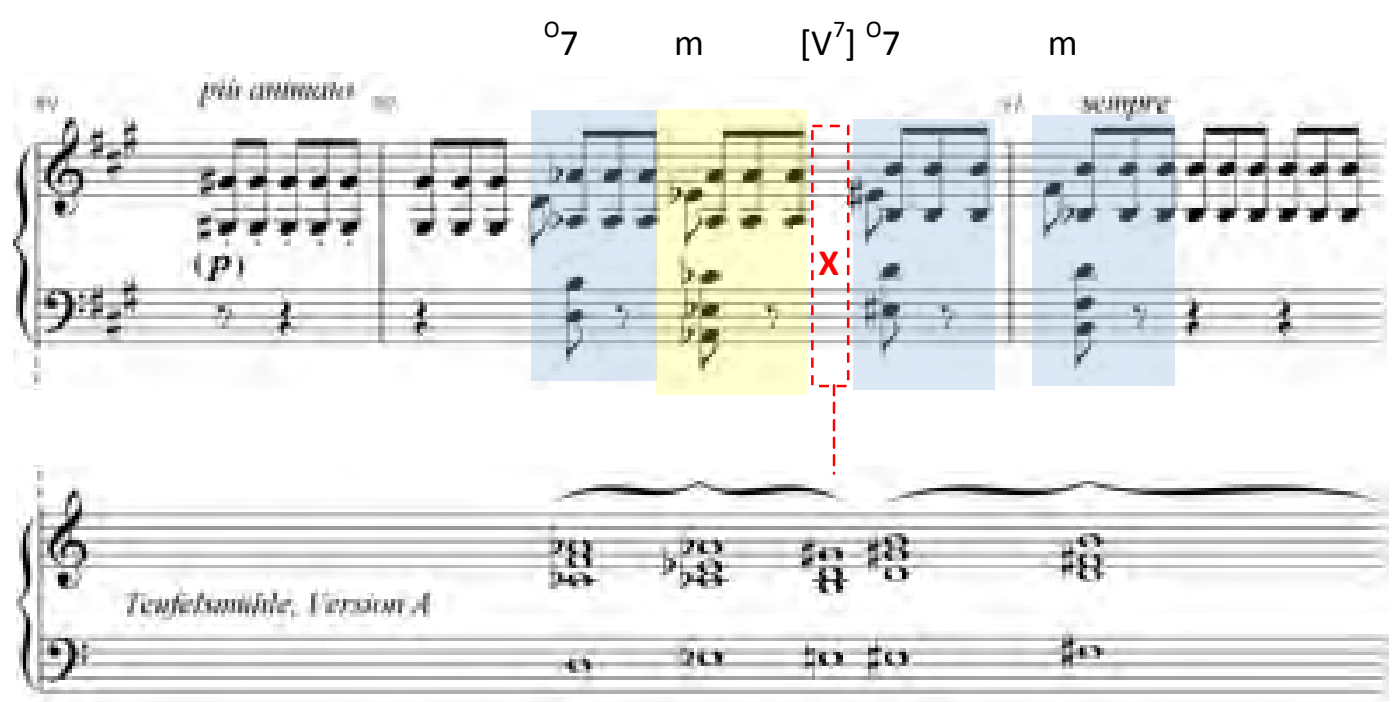



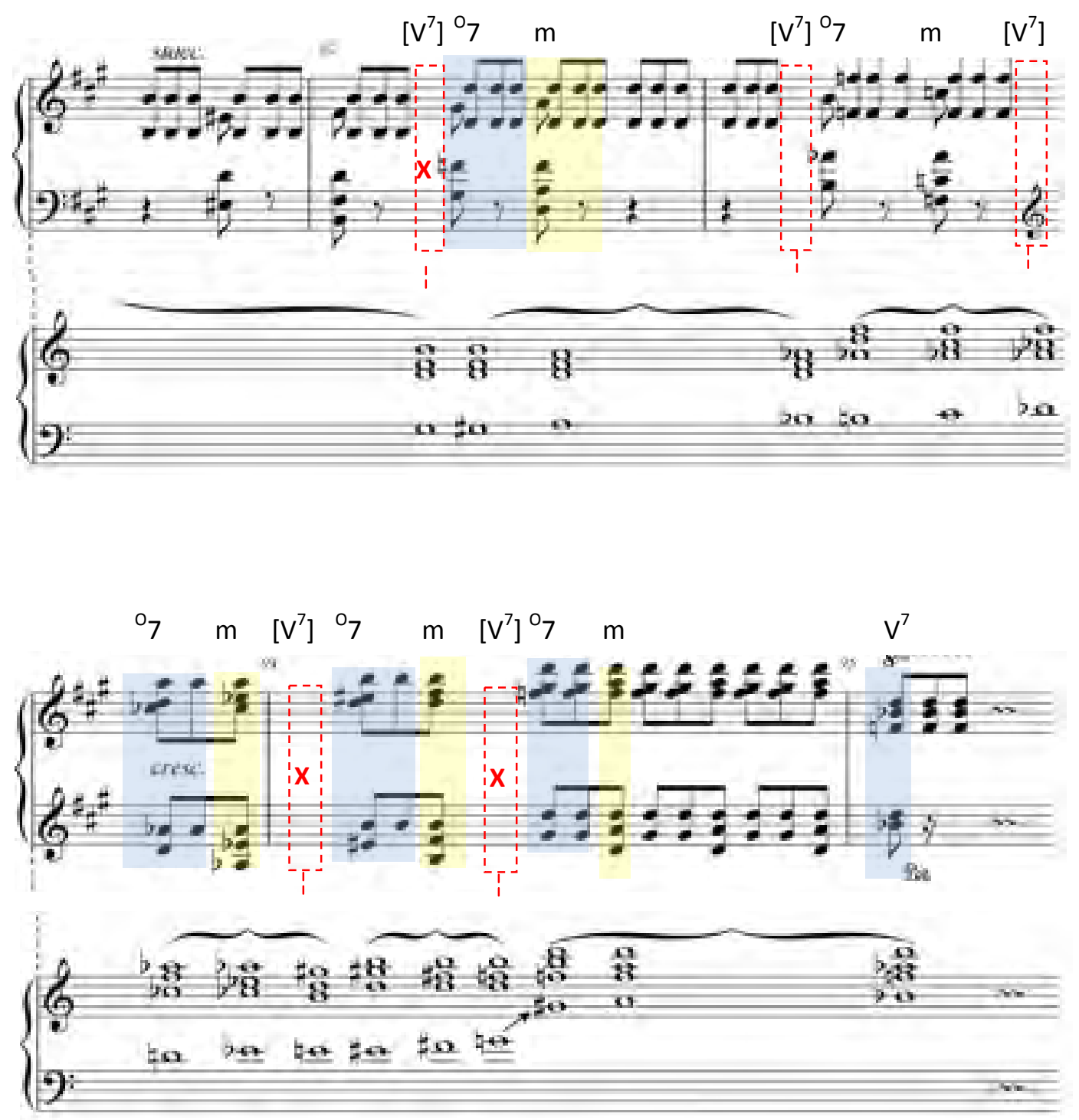

Todas as notas envolvidas formam a escala octatônica:

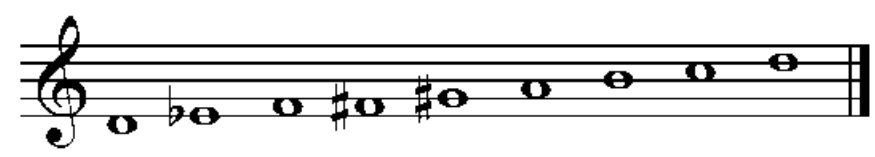

Todas as variantes citadas até então dizem respeito às modificações pertinentes a versão A do Teufelsmühle e recebem, por parte de Seidel, uma atenção especial pelo vínculo com a música de Liszt e com o segundo modo. 


\section{1 . 4 . 4 - Variante do Teufelsmühle versão B}

Em sua forma original, o padrão da versão B não apresenta vínculo direto com o segundo modo, pois o acorde de sétima diminuta é aqui substituído por uma dominante com sétima no baixo. Contudo, Seidel aponta que:

Diferentemente da versão $\mathrm{A}$ do Teufelsmühle, a versão B não contém o segundo modo em nenhuma de suas vozes, mas apenas a escala cromática. [...] Contudo, mesmo a versão B pode ser convertida em uma sequência de acordes do segundo modo por meio de um pequeno truque. É preciso apenas omitir todos os acordes menores com quarta e sexta [...] (SEIDEL, 1981, p. 175).

Assim, a versão B com a omissão do acorde menor com quarta e sexta passa a conter apenas dois acordes, ambos sobre a mesma harmonia de dominante e com troca de vozes (Ex. 28).

\section{Exemplo 28 - Padrão do Teufelsmühle versão B e sua variante}

Padrão do Teufelsmühle

Variante da Versão B:

Versão B omissão do acorde menor com quarta e sexta

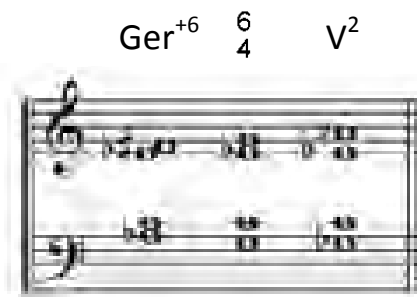

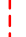

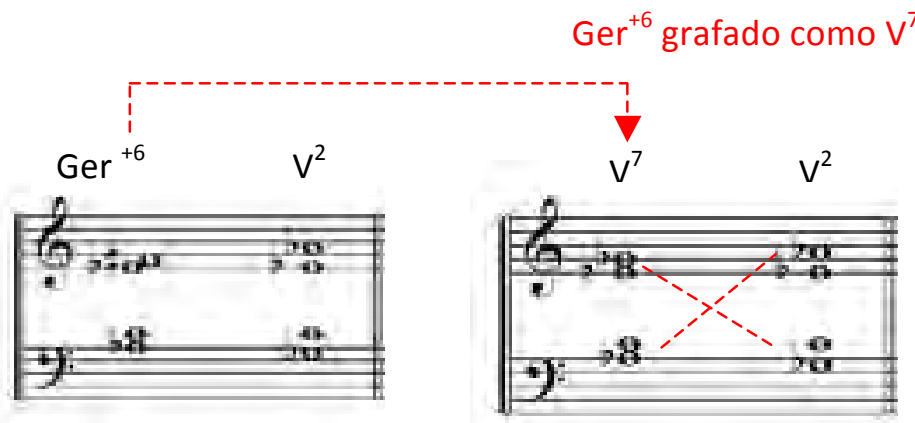

troca de vozes

omissão do acorde menor com quarta e sexta

Este procedimento é empregado por Liszt duas vezes em seu Terceiro Estudo de Concerto "Suspiro", no trecho entre os compassos 42 - 46 e no final, compassos 66 - 70. 0 exemplo 29 oferece o trecho final acompanhado por sua redução. 
Exemplo 29 - Liszt: “Suspiro“, comps. 66 - 70 (SEIDEL, 1981, p. 191 - 193)
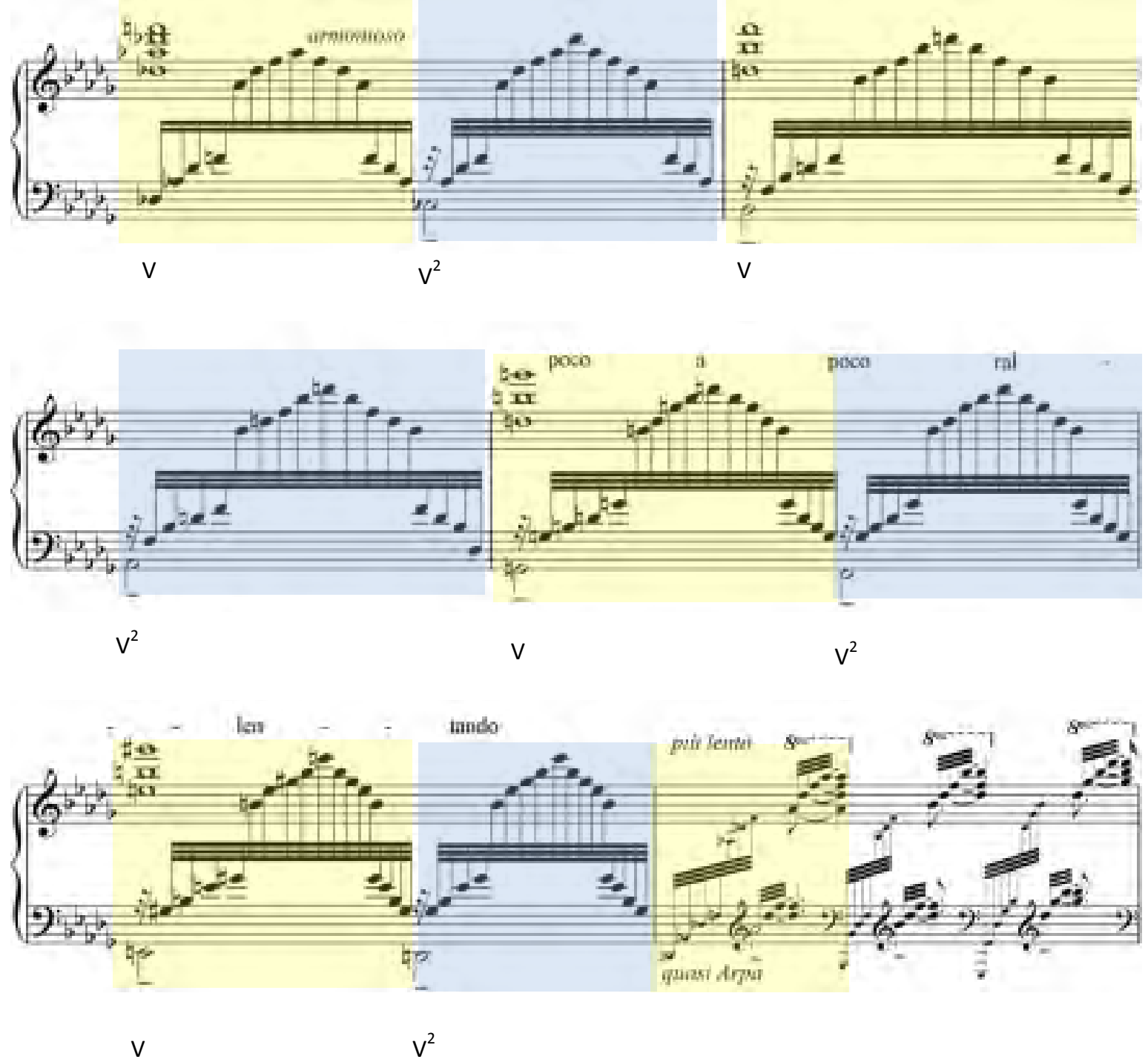

\section{Redução}

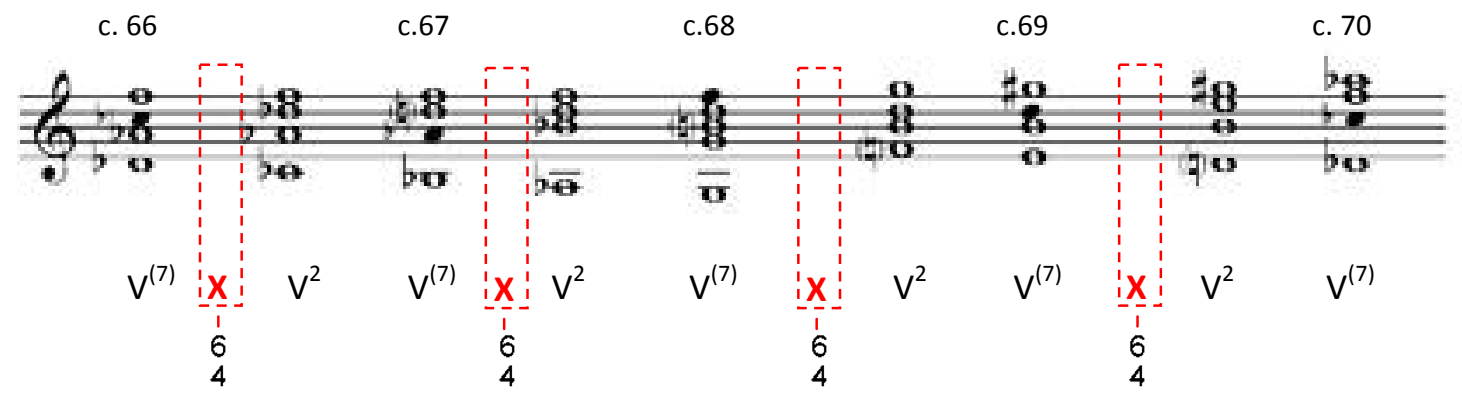

Nesta passagem do Terceiro Estudo, Liszt faz uso da variante da versão B do Teufelsmühle com a omissão de todos os acordes menores com quarta e sexta, além de outra alteração: a tríade maior em estado fundamental no lugar da dominante com sétima 
menor. Este uso, embora bastante variado, ainda preserva o segundo modo de transposição limitada, como pode ser constatado pela disposição linear de todas as notas envolvidas na passagem que formam a escala octatônica (Ex. 30).

Exemplo 30 - A escala octatônica no "Suspiro" de Liszt: comps. 66 - 70

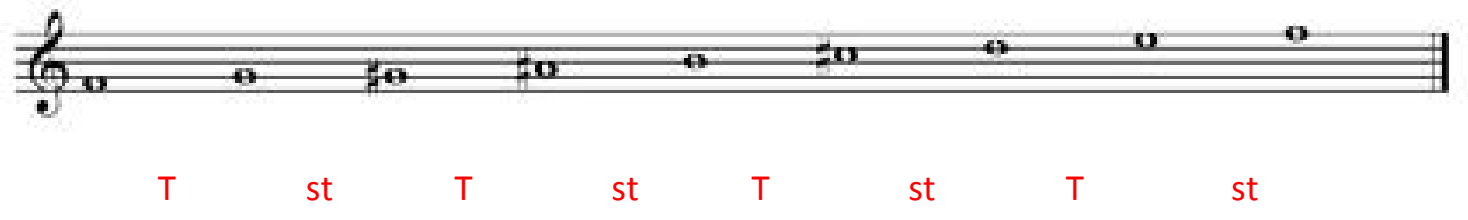




\section{CAPÍTULO 2}

\section{Omnibus: a visão americana}

O primeiro referencial em língua inglesa inteiramente dedicado à progressão omnibus foi o livro The omnibus idea (1998) de Victor Fell Yellin ${ }^{1}$. Organizado em nove partes, seu livro consta de uma introdução na qual é apresentada a definição da progressão omnibus clássica, a explicação das nomenclaturas criadas para a identificação destes trechos, além de hipóteses sobre a origem desta sequência no âmbito teórico e histórico. Os oito capítulos seguintes ${ }^{2}$ trazem exemplos da literatura musical, identificados e analisados sob esta nova perspectiva. Além disso, o autor explora em alguns casos, o uso da progressão associado a um efeito dramático, principalmente no gênero operístico, ao propor relações entre a estrutura musical e o contexto poético.

É importante salientar que a primeira publicação a fazer referências à progressão omnibus foi o livro Viennese Harmonic Theory from Albrechtsberger to Schenker and Schoenberg (1985) de Robert W. Wason ${ }^{3}$. Entretanto, os créditos foram dados a Victor Yellin, por suas pesquisas e artigos apresentados em congressos, já na década de setenta, mas não publicados, que serviram como base teórica para Wason e os demais autores americanos ${ }^{4}$.

Estudos representativos sobre o emprego da estrutura omnibus foram também expostos por Paula Telesco, primeiramente, em sua tese de doutorado Enharmonicism in Theory and Practice in 18th Century Music (1993) e posteriormente no artigo "Enharmonicism and the Omnibus Progression in Classical-Era Music" (1998). Além disso, a autora fez uma resenha crítica do livro The omnibus idea de Yellin (2001).

A partir destes referenciais mencionados na vertente americana, pretende-se realizar uma revisão bibliográfica sobre a progressão omnibus, de forma crítica e ampliada pelos estudos advindos da corrente alemã.

Este capítulo se concentrará nas características estruturais do omnibus e, para um melhor entendimento, será organizado e dividido em três itens. O primeiro, entitulado "a

\footnotetext{
${ }^{1}$ Vale ressaltar que Yellin apresentou o primeiro artigo sobre a natureza e significado do omnibus em 1972 no

${ }^{2}$ A saber: final do século XVIII e início do século XIX; óperas no início do romantismo; óperas românticas; música de concerto romântica; Liszt; final do século XIX; música popular; e música do início do século XX.

${ }^{3}$ Nesta obra são encontrados, aspectos das teorias de Vogler, Förster e Sechter relacionados à progressão omnibus.

${ }^{4}$ Dentre eles, Jan LaRue, Mark DeVoto, J. C. Schmidt, John Knowles Paine, Henry Zajaczkowski, Stan Shumway e Paula Telesco.
} 
progressão omnibus", apresentará o conceito, a cifragem e as tipologias dos acordes, dentre outros aspectos. No segundo será exposto o processo de mutação, fator característico da progressão e que Ihe confere funções modulatórias. Por fim, o terceiro tópico abordará as variantes do padrão e as terminologias empregadas pelos diferentes autores.

\section{1 - A PROGRESSÃO OMNIBUS}

A atuação de Yellin como professor o levou a observar, refletir, investigar as causas e a formular uma saída para aproximar os alunos do evento estrutural que ele nomeou como progressão omnibus ${ }^{5}$. Segundo o autor, sua intenção inicial " [...] era simplesmente achar um modo claro e fácil de explicar os mistérios da harmonia cromática para os estudantes de pósgraduação da Universidade de Nova lorque" (YELLIN, xi, 1998). Foi então com uma preocupação eminentemente pedagógica que ele iniciou sua longa pesquisa, de aproximadamente trinta anos, que culminou na publicação de seu livro The Omnibus Idea.

Ao enumerar e criticar vários livros didáticos de harmonia do final do século XIX e início do século $X X^{6}$, bem como outros ainda utilizados atualmente no ensino da disciplina ${ }^{7}$, Yellin constata que "quanto mais a ideia omnibus era empregada na música [...], menos ela era explicada ou mesmo identificada em sala de aula" (YELLIN, 1998, p. 7).

Visto que a questão pedagógica foi um dos principais motivos para que o autor desenvolvesse sua pesquisa, é curioso notar o paradoxo existente entre a forma truncada com que Yellin expõe o seu conceito e o compromisso didático assumido por ele. Isto é facilmente observado logo em sua introdução, em que toda a explanação conceitual é feita apenas em dois exemplos e sem etapas intermediárias. Além disso, aspectos inerentes à progressão omnibus são somente subentendidos ou sugeridos em momentos distintos de seu livro, de modo que importantes questões referentes à origem teórica, histórica e de cifragem são abordadas por ele de maneira descontínua e insuficiente.

\footnotetext{
${ }^{5}$ Yellin assume não ter sido o primeiro a empregar o termo omnibus e revela tê-lo ouvido pela primeira vez por meio de Roger Martinez num seminário sobre ópera romântica realizado na Universidade de Nova lorque. (YELLIN, 1998, p. 97).

${ }^{6}$ Por exemplo, Harmony (1897) de George Whitefield Chadwick e Modern Harmony (ed. rev., 1936) de Arthur Foote e Walter R. Spalding.

7 Por exemplo os livros de harmonia de W. Piston (1941) e de H. Schenker (1954), bem como Funções Estruturais da Harmonia de A. Schoenberg (1969). Cf. YELLIN (1998, p. 13-14 e p. 97-98).
} 
Assim, a partir dos dois exemplos iniciais de Yellin, este texto pretende propor passos preliminares e intermediários para aclarar todas as informações contidas na definição exposta pelo autor.

Desta forma, seu primeiro exemplo (Ex. 31) apresenta a progressão omnibus na forma assumida como padrão clássico. As expressões omnibus progression, classic omnibus, omnibus cliché, omnibus chain ou omnibus serie são também empregadas pelo autor para designar tal forma de apresentação, definida como:

Em sua forma clássica, a progressão omnibus pode ser descrita como um encadeamento de cinco acordes começando com o (1), uma dominante com sétima em primeira inversão com a fundamental no soprano. Enquanto as vozes internas, tenor e contralto, formando um intervalo de terça menor, permanecem estáveis como notas pedais ou duplo pedal, as duas vozes extremas, soprano e baixo, expandem-se por movimento contrário em quatro passos cromáticos. Os acordes resultantes (2) (3) (4) e (5) não são nomeados tão facilmente. Mas o acorde central (3) pode ser reconhecido como um acorde menor com quarta e sexta posicionado entre os acordes (2) e (4), os quais podem ser considerados seja como um acorde de dominante com sétima ou de sexta aumentada. A série termina com o acorde (5), a mesma harmonia do acorde (1), mas em posição fundamental e com a terça no soprano. (YELLIN, 1998, p. 3)

\section{Exemplo 31 - Progressão omnibus - padrão clássico de V. Yellin (1998, p. 4)}

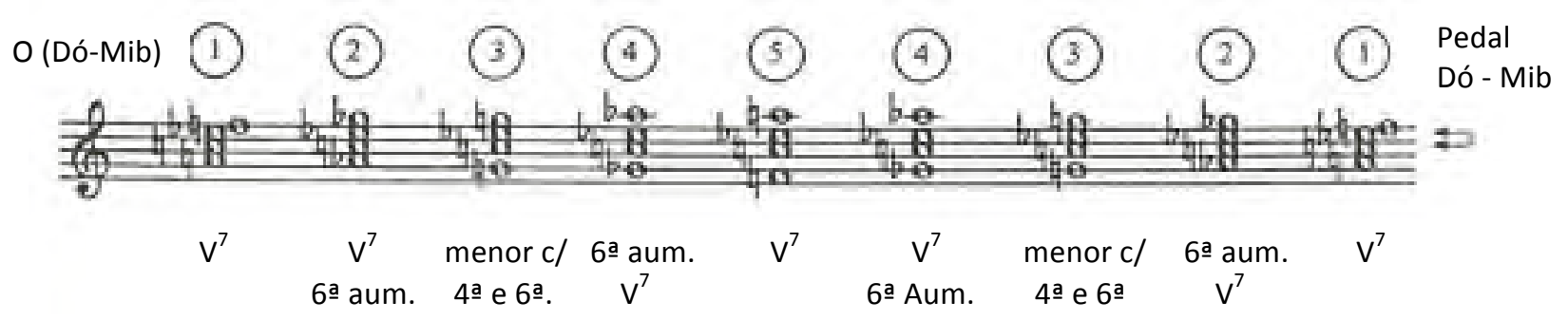

A sinalização O (Dó-Mib) diz respeito à representação da progressão omnibus "O", seguida pela indicação entre parênteses das notas mantidas. Por convenção, a nota mais grave do pedal é colocada primeiro.

É inevitável constatar o excesso de informações contidas neste exemplo. Aqui, Yellin, de uma só vez, apresenta sua nova nomenclatura, classifica as tipologias, aponta possibilidades de reinterpretações enarmônicas e vetores reversíveis. Além disso, a ausência 
de exemplos que contenham esclarecimentos relevantes à série isolada, com apenas os cinco acordes que formam o padrão clássico, dificulta o entendimento da progressão.

Neste sentido, o exemplo seguinte oferece em três etapas os passos que precedem à definição da progressão clássica. O exemplo 32a traz uma passagem a duas vozes, em que é empregado o acorde (1) da série, uma dominante em primeira inversão e com a fundamental no soprano, que por troca de vozes e notas de passagem diatônicas, atinge a mesma dominante em estado fundamental e com a terça na voz superior, o equivalente ao acorde (5).

No exemplo 32b, a quatro vozes, as tipologias correspondentes aos acordes (1), (3) e (5) da série são descritas como resultantes da simultaneidade das vozes e, portanto, com clara origem no contraponto. O exemplo 32c ilustra o preenchimento com notas de passagens cromáticas, nas vozes extremas, entre os acordes (1), (3) e (5). Embora este último item possa gerar uma visão vertical, que permite a identificação de tipologias iguais às dos cinco primeiros acordes do exemplo 31, vale ressaltar que o princípio desta estrutura é fundamentalmente contrapontístico, em que duas vozes realizam movimento contrário cromático e simétrico enquanto que duas vozes permanecem mantidas como pedal.

\section{Exemplo 32 - Passos preliminares para a definição do padrão clássico}

a)

troca de vozes

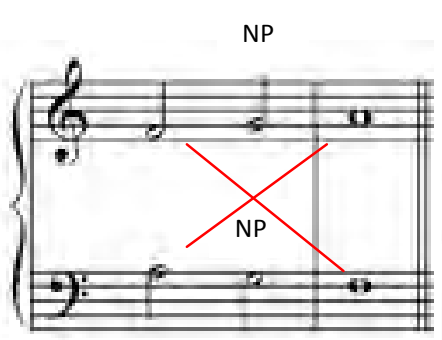

SibM: $v^{6}$ V b)

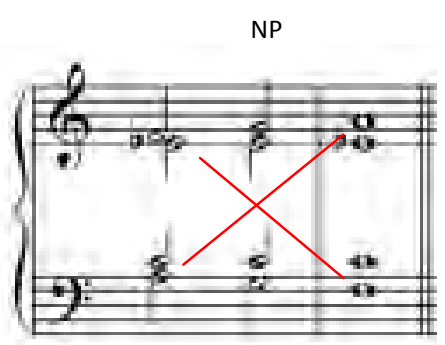

NP

(1) (5)

(1)

A fim de contextualizar as etapas já mencionadas na formação do padrão clássico, o exemplo 33 apresenta, na tonalidade de SibM, a progressão omnibus completa, com os cinco acordes cifrados de acordo com a nomenclatura de Yellin, com a indicação em vermelho de 
troca de vozes entre o (1) e (5), em azul das notas mantidas como pedal ${ }^{8}$, além da ênfase na análise harmônica como expansão de dominante ${ }^{9}$.

\section{Exemplo 33 - Progressão omnibus: padrão clássico}

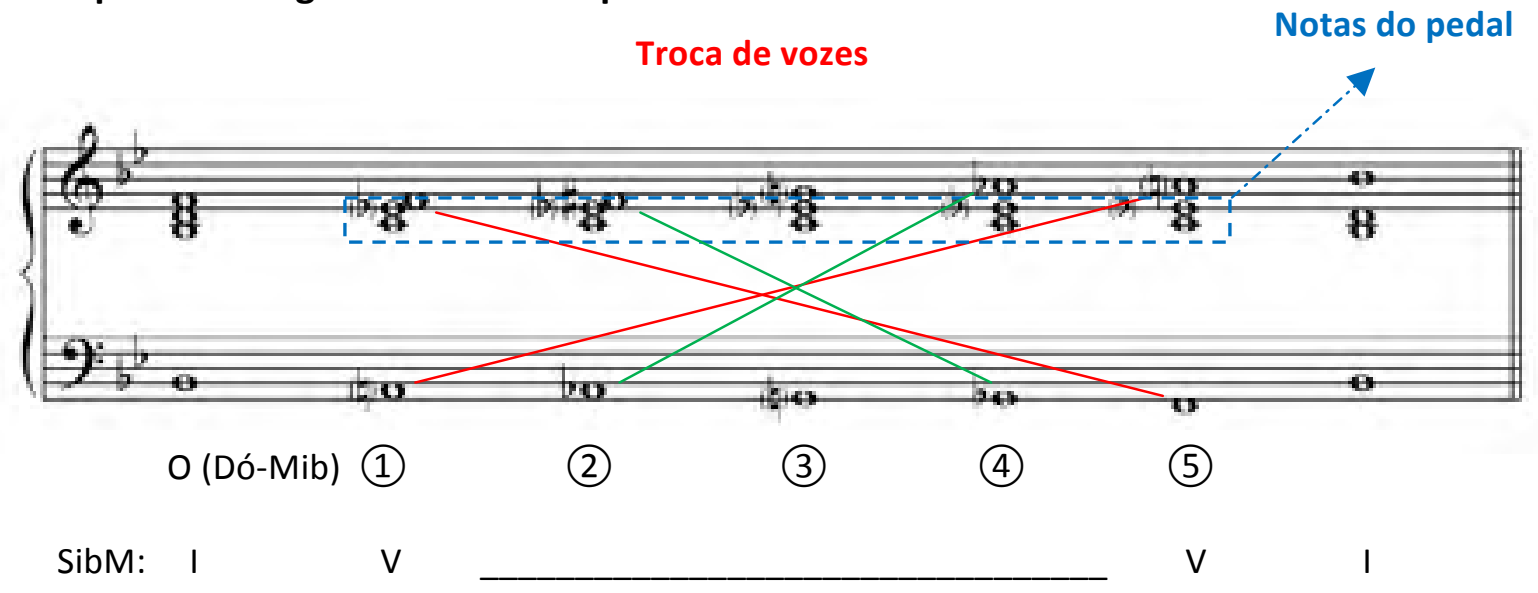

Uma análise mais detalhada deste exemplo torna possível observar que, de forma análoga aos acordes (1) e (5), o (2) e (4) apresentam a mesma sonoridade com troca de vozes entre eles, assinalada em verde.

Após esta exposição inicial, pode-se afirmar que a definição do padrão clássico da progressão omnibus que Yellin elabora está vinculada ao processo de interdependência entre o aspecto horizontal e o vertical, em que todas as notas, inclusive as notas de passagem cromáticas, também são interpretadas como parte integrante dos acordes ${ }^{10}$.

Um exemplo do padrão clássico na prática composicional ocorre no trecho a seguir, extraído da Sonata D845 em Lá menor de Schubert. A partir da segunda metade do compasso 35 a série O (Ré-Fá) e apresentada com os acordes (1) (2) (3) (4) (5), com as notas Ré e Fá do

${ }^{8}$ Para uma primeira exposição da progressão omnibus, as notas cromáticas apresentam-se nas vozes extremas enquanto que as notas mantidas estão nas vozes internas. Contudo, tais disposições podem ser feitas de diversas maneiras, como será demonstrado adiante nesta dissertação.

${ }^{9}$ Vale ressaltar que tal progressão não se refere apenas a uma expansão da dominante principal, tal prolongamento pode ser feito em qualquer dominante ou $\mathrm{Ger}^{+6}$.

${ }^{10}$ Segundo Yellin, a inversão simétrica exposta pelo teórico teuto-americano Bernhard Ziehn (1845-1912) em seus Estudos Canônicos (1912) "[...] é a melhor demonstração teórica do princípio sobre o qual a idéia omnibus é baseada" (YELLIN, 1998, p. 9). Sob o título de cânones em terça menor ou sexta maior, Ziehn não se preocupou em identificar e nomear a progressão omnibus como uma locução musical com importância histórica, o objetivo era fornecer uma base contrapontística cromática para compositores da época (YELLIN, 1998, xii). Contudo, ocorre que Robert Wason, em seu livro Viennese Harmonic Theory from Albrechtsberger to Schenker and Schoenberg aponta que o teórico alemão Simon Sechter (1788-1867) em seu Generalbaßschule (1830, p. 100) " [...] tomou um segmento da harmonização da escala cromática do Vogler e a modificou de forma que a progressão resulta na troca de componentes de um acorde de dominante com sétima - o "omnibus clássico" de Yellin" (WASON, 1985, p. 57). Assim, embora Wason seja uma das fontes bibliográficas em The omnibus Idea, é curioso notar que Yellin não considera o tratado de Sechter, que de fato apresenta a progressão omnibus muito antes de tal formulação Téo rica de Ziehn. Para mais informações acerca da inversão simétrica e sua relação com a formação dos acordes do omnibus clássico, cf. (YELLIN, 1998, p. 4 - 12). 
pedal nas vozes internas e o cromatismo nas vozes externas. A passagem dos compassos 34 a 37, na região de Dó maior, reflete uma expansão da dominante, acorde de Sol maior com sétima menor.

Exemplo 34 - Schubert: Sonata D845 em Lám, comps. 34 - 37 (YELLIN, 1998, p. 29)

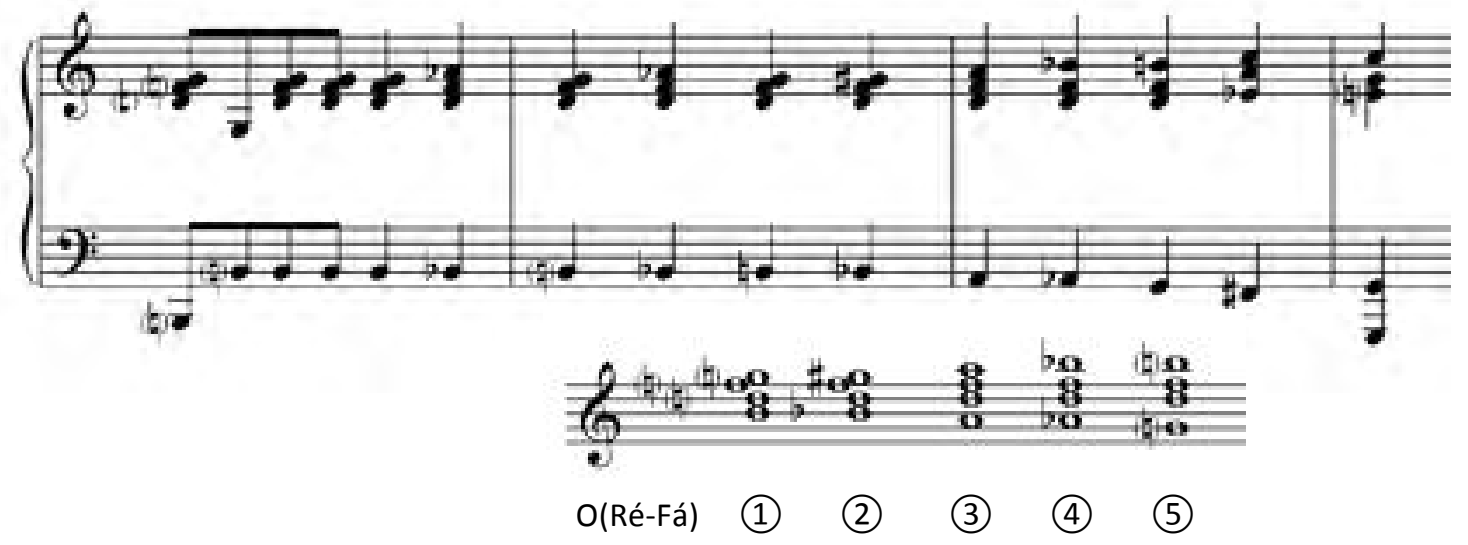

Os próximos dois exemplos comentam questões estruturais inerentes ao padrão clássico, relacionadas às tipologias de acordes e a presença de relações de simetria. No exemplo 35, os acordes (1) e (5) apresentam-se como dominantes com sétima, já os acordes (2) e (4) podem ocorrer na forma de dominante com sétima ou como sexta aumentada. $O$ único acorde diferente é o (3), menor com quarta e sexta, que se configura como um eixo de simetria.

Exemplo 35 - Eixo de simetria no padrão clássico

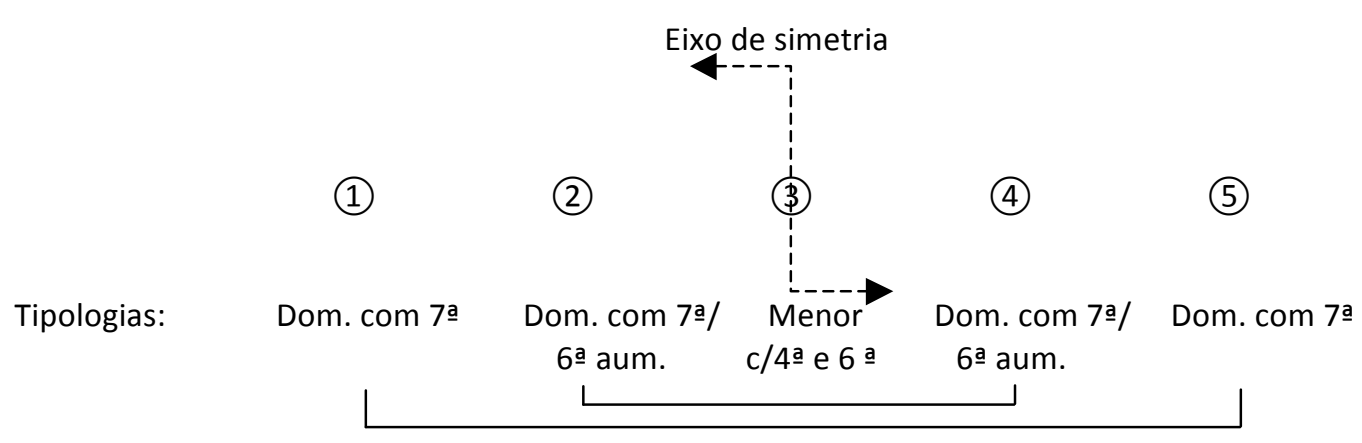

Assim, os acordes presentes na série omnibus são agrupados em três categorias: dominante com sétima, acorde de sexta aumentada e acorde menor com quarta e sexta.

Reconhecidas as propriedades desta estrutura, pode-se retornar ao exemplo $31 \mathrm{e}$ observar que a série formulada por Yellin gera vetores reversíveis (Ex. 36), em que estes 
números arábicos circulados podem ser empregados tanto na forma original:

(1) (2) (3) (4)

(5) quanto na versão retrógrada: (5) (4) (3) (2) (1).

Exemplo 36 - Forma original e na versão retrógrada

Eixo de simetria

(1)

(2)

(3)

(4)

(5)

(4)

(3)

(2)

(1)

Para ilustrar de forma contextualizada a apresentação da série em sua versão original, o exemplo 37 traz um trecho das Variações Sérias Op. 54 de Mendelssohn, em que se pode observar a progressão clássica sobre a dominante principal na tonalidade de Rém. As notas Mi e Sol formam o duplo pedal nas vozes internas e o cromatismo é colocado nas vozes extremas.

Exemplo 37 - Mendelssohn: Variações Sérias Op. 54, var. 9, comps. 155 - 160
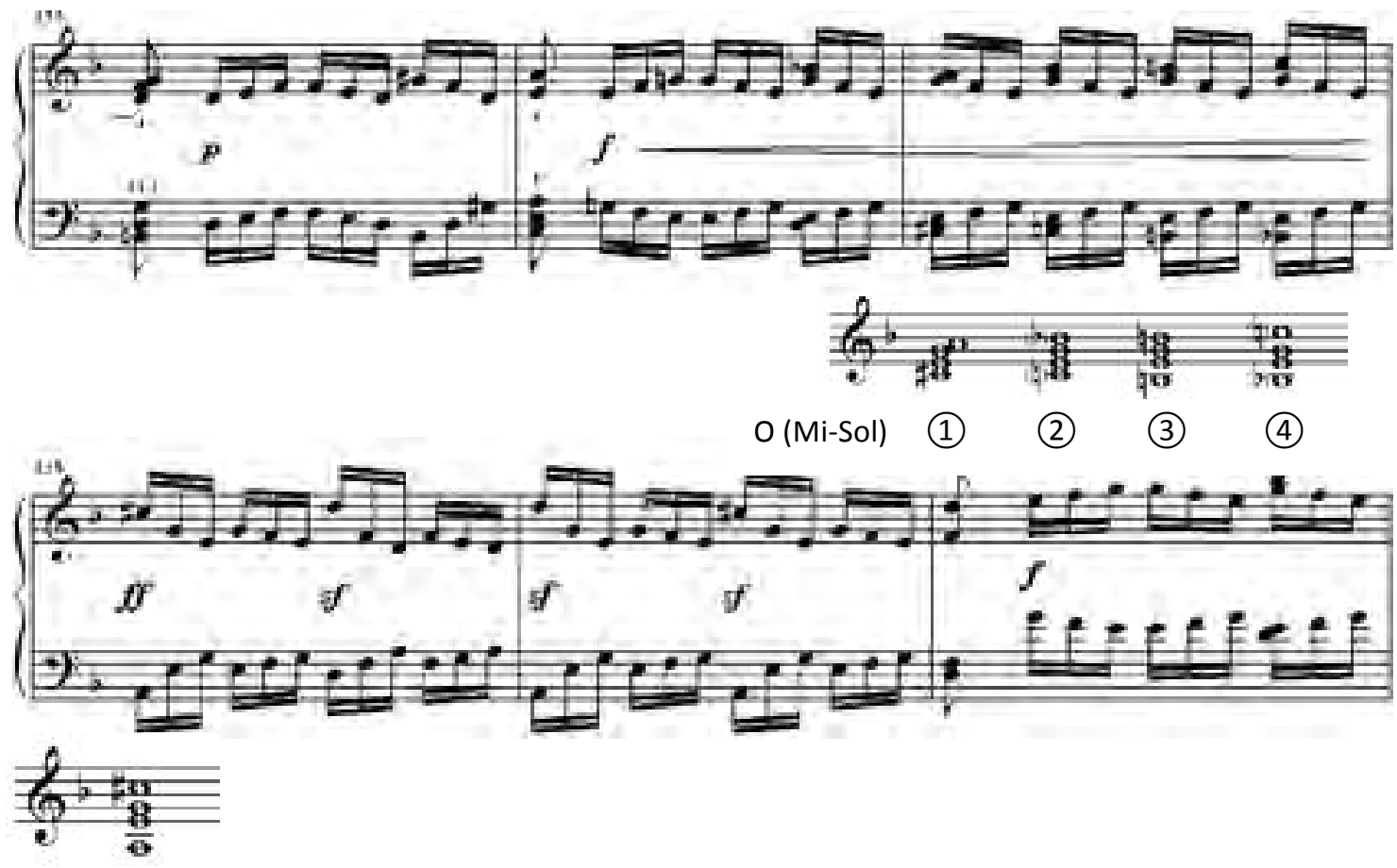

(5) 
Neste momento é possível retornar novamente ao exemplo 31 e explicá-lo também sob o ponto de vista de outro aspecto estrutural previsto no padrão clássico: a reinterpretação enarmônica ${ }^{11}$.

Deve-se salientar que os acordes da progressão podem propiciar, a qualquer momento da série, uma multiplicidade de direcionamentos harmônicos por meio de reinterpretações enarmônicas entre o acorde de dominante com sétima e o acorde de sexta aumentada, potencialmente os acordes (1), (2), (4) e (5) ${ }^{12}$.

No final da introdução de seu livro, Yellin ilustra algumas possibilidades de reinterpretações enarmônicas aplicadas à progressão omnibus, analisadas tanto pela nomenclatura tradicional quanto por sua nova cifragem.

Exemplo 38 - Possibilidades de reinterpretações enarmônicas (YELLIN, 1998, p. 14)

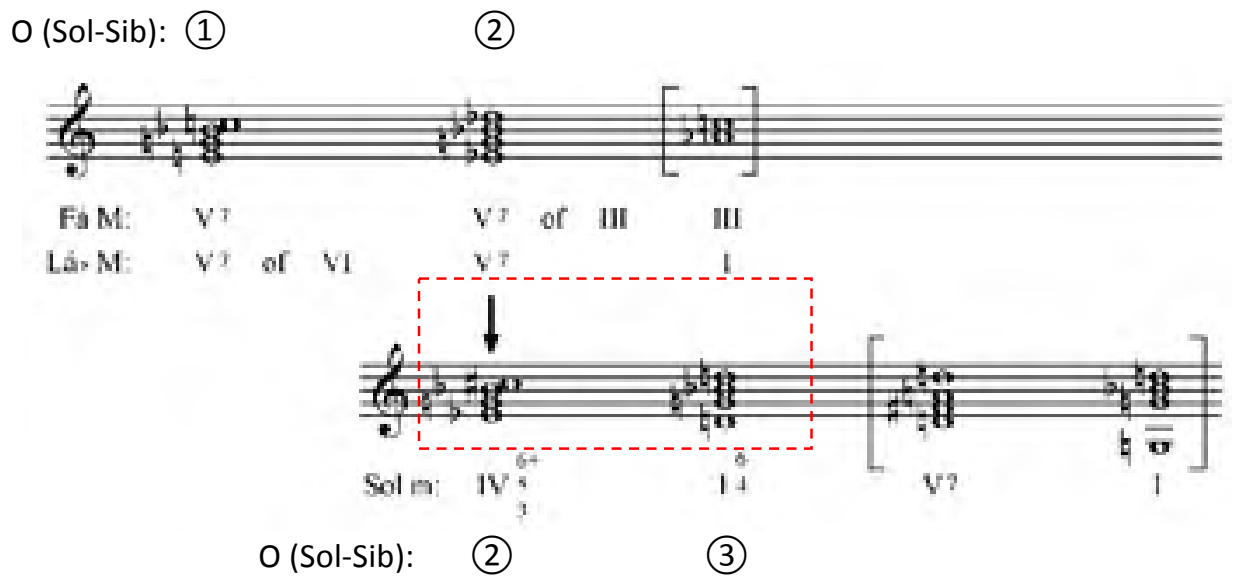

Neste exemplo pode-se observar que se o acorde (2) resolver como dominante com sétima, este passará a assumir a função de uma dominante secundária e o padrão clássico será logo interrompido, ao passo que se reinterpretado como um acorde de sexta aumentada alcançará o acorde (3) previsto na progressão. Em seguida, é possível notar que a interrupção da progressão omnibus no acorde (3) provoca a interpretação deste como um acorde de dominante com quarta e sexta, de modo que a tonalidade alcançada, neste caso, será Sol menor ${ }^{13}$.

\footnotetext{
${ }^{11}$ Conferir capítulo1, item 1.3.

12 Embora o (3) possa vir a assumir a função de uma dominante, o fato de estar disposto com as dissonâncias de quarta e sexta faz com que sua reinterpretação como acorde de sexta aumentada não seja usual.

${ }^{13}$ Yellin associa a reinterpretação enarmônica às mudanças "repentinas" de tonalidade e à troca de emoção ou atmosfera (1998, p. 14).
} 
É importante então ressaltar que estas possibilidades de reinterpretações garantem à progressão omnibus uma abrangência maior do que uma expansão de dominante. Embora tal interpretação esteja correta em sua essência, não traduz o potencial que tal estrutura possui e que muitos compositores exploraram de forma particular ${ }^{14}$.

\section{2 - MUTAÇÃO}

Provavelmente a característica mais fascinante do omnibus é a sua habilidade de mutação (TELESCO, 1998, p. 129).

A citação acima enaltece um dos principais procedimentos vinculado ao omnibus, a mutação ${ }^{15}$. Deve-se ressaltar que este termo é empregado pela primeira vez por Yellin e que não há um consenso quanto à denominação deste processo, de modo que é possível encontrar diferentes nomenclaturas, tais como: "extended omnibus" (WASON, 1985, p. 18), “overlapping series" (TELESCO, 2001, p. 129), “overlapped omnibus” (TELESCO, 1998, p. 260).

No segundo exemplo de The omnibus Idea é apresentada uma série omnibus inicial associada a outras duas novas séries pelo processo de mutação (Ex. 39), que o autor define da seguinte maneira:

[...] uma nova série pode ser iniciada ao se constatar um novo pedal duplo (terça menor/sexta maior) na terminação da progressão. Quando as notas Dó e Mib do pedal, quinta e a sétima menor do acorde (5) da série original são abandonados, novas notas pedais, Dó e Lá, a quinta e a terça transformam o acorde (5) no acorde (2) da nova série. [...] Mutações similares podem ser empregadas para prolongar o baixo indefinidamente (YELLIN, 1998, p. 3).

${ }^{14}$ Algumas possibilidades do uso desta progressão cromática na prática composicional serão explicadas e contextualizadas com mais detalhes no item 2.3, bem como na segunda parte desta dissertação.

${ }^{15}$ Yellin emprega este termo em uma analogia com o processo de mutação do sistema hexacordal. Para mais informações sobre esta relação estabelecida pelo autor, conferir (1998, p. 98-99). 


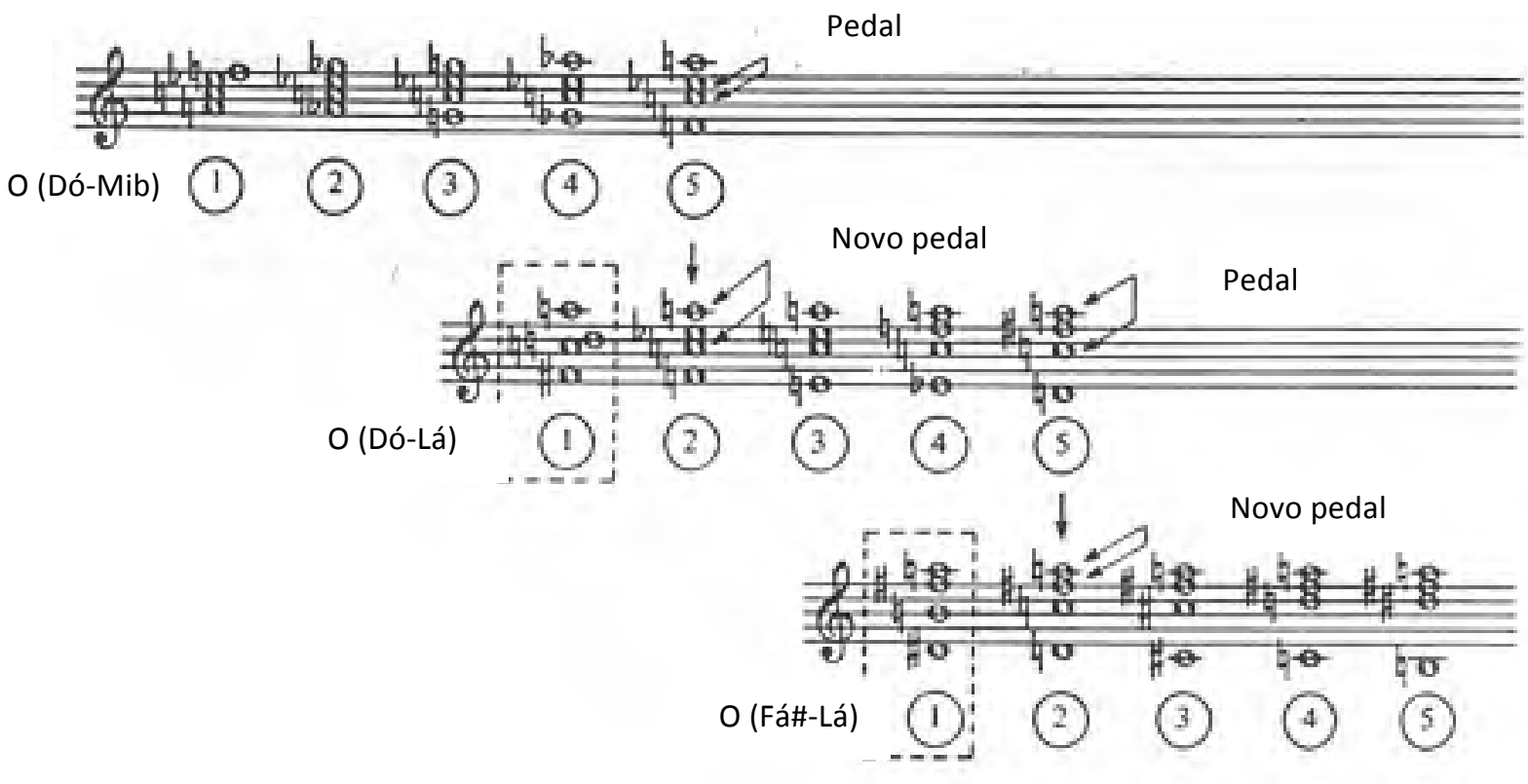

A forma parcial e com pouco detalhamento com que Yellin descreve a mutação evidencia sua preocupação apenas com o aspecto da condução de vozes, uma vez que são enfatizados como fatores determinantes a troca do duplo pedal e o prolongamento do baixo cromático. Entretanto, os pontos que esta dissertação também considera como imprescindíveis e que estão ausentes na definição de mutação do autor dizem respeito às possibilidades de modulações advindas das reinterpretações enarmônicas, assim como o vínculo com o acorde diminuto.

Assim, a seguir, este texto se propõe a detalhar o processo de mutação, por meio de uma explanação mais minuciosa acerca do vínculo com a reinterpretação enarmônica. Além disso, pretende-se explicitar as relações com a estrutura do acorde diminuto e contextualizar em exemplos isolados e extraídos do repertório musical.

A análise do exemplo 40 permite relacionar, numa perspectiva harmônica, a transformação do acorde (5) da série original O (Dó-Mib) no (2) de uma nova série 0 (Dó-Lá), por meio da reinterpretação enarmônica de uma dominante com sétima em um acorde de sexta aumentada germânica, exato momento em que ocorre a troca das notas do duplo pedal. 


\section{Exemplo 40 - Reinterpretação enarmônica entre o (5) e o (2)}

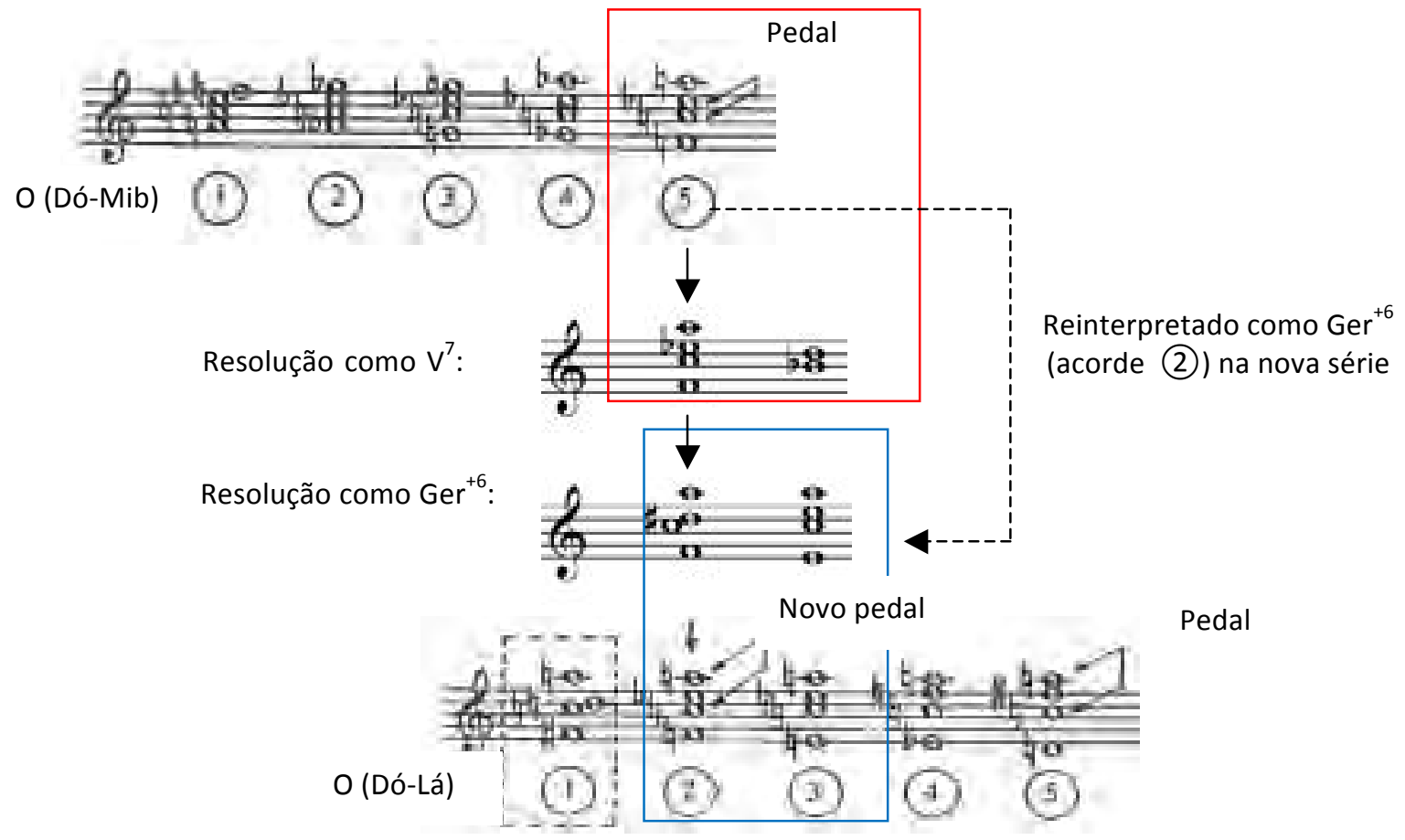

A omissão deste vínculo na exposição de Yellin contraria a própria natureza da progressão, pois não enfatiza a interdependência entre os planos horizontal e vertical, além de não evidenciar a propriedade que edifica esta estrutura e que oferece novos direcionamentos cadenciais: a reinterpretação enarmônica.

Um aspecto que chama atenção e que desperta questionamentos, refere-se à escolha dos acordes (5) e (2) como integrantes fundamentais no eixo do processo de reinterpretação.

A tabela a seguir (Ex. 41) é resultado da reflexão desta dissertação, que neste momento procura evidenciar as razões pelas quais a reinterpretação enarmônica só possa ocorrer, na mutação, entre (5) e (2). Assim, a investigação pretende reinterpretar cada acorde do padrão clássico como sexta aumentada ${ }^{16}$ e verificar a presença do acorde de resolução na série original ou numa nova série. Com isto, pretende-se comprovar quais as possibilidades de acordes reinterpretados permitem a continuidade da sequência.

\footnotetext{
${ }^{16}$ Esta tipologia pode ocorrer fora de sua condução de vozes usual, de forma que o intervalo característico de sexta aumentada passa a figurar como terça diminuta, cf. Piston (1987, p. 422). Isto ocorre no acorde (1) e (4) da tabela do exemplo 41.
} 
Exemplo 41 - Possibilidades de reinterpretações enarmônicas a partir de cada um dos acordes do padrão clássico:

\begin{tabular}{|c|c|c|c|c|}
\hline $\begin{array}{l}\text { Acordes do omnibus no } \\
\text { padrão clássico e sua } \\
\text { cifragem }\end{array}$ & $\begin{array}{l}\text { Acorde enarmonizado } \\
\text { como Ger }\end{array}$ & $\begin{array}{c}\text { Resolução como } \\
\text { Ger }^{+6}\end{array}$ & $\begin{array}{l}\text { Tipologia da } \\
\text { resolução }\end{array}$ & $\begin{array}{c}\text { Posição na série } \\
\text { ominbus }\end{array}$ \\
\hline$\frac{6 \log _{8}}{\text { (1) }}$ & $6 \mathrm{xan}_{0}^{2}$ & $\frac{9}{6} 8^{-00}$ & $\begin{array}{c}\text { Acorde menor } \\
\text { em primeira } \\
\text { inversão }\end{array}$ & $\begin{array}{c}\text { Não existe esta } \\
\text { tipologia no } \\
\text { omnibus }\end{array}$ \\
\hline$\frac{2}{2}$ & $\frac{f}{2}=800$ & 68 & $\begin{array}{l}\text { Acorde menor } \\
\text { com quarta e } \\
\text { sexta }\end{array}$ & $\begin{array}{l}\text { (3) } \\
\text { da série } \\
\text { original }\end{array}$ \\
\hline 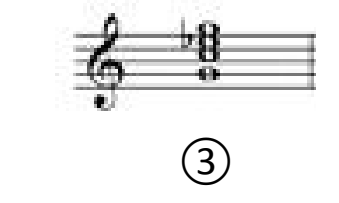 & Não usual ${ }^{17}$ & & & \\
\hline$\frac{2,8}{60}$ & $-\frac{6}{6}, 8$ & a 8 & $\begin{array}{l}\text { Acorde menor } \\
\text { com quarta e } \\
\text { sexta }\end{array}$ & $\begin{array}{c}\text { (3) } \\
\text { da série } \\
\text { original }\end{array}$ \\
\hline $\begin{array}{l}\frac{8}{8} \\
0 \\
0\end{array}$ & $\frac{7}{6}: \frac{0}{0}$ & $\frac{8}{8}$ & $\begin{array}{l}\text { Acorde menor } \\
\text { com quarta e } \\
\text { sexta }\end{array}$ & $\begin{array}{c}\text { (3) } \\
\text { de uma } \\
\text { nova série }\end{array}$ \\
\hline
\end{tabular}

${ }^{17}$ Embora o (3) possa vir a assumir uma função de dominante, o fato de estar disposto como um acorde com quarta e sexta faz com que sua reinterpretação como acorde de sexta aumentada não seja usual. 
A análise dos resultados da tabela comprova então que o (5) da série original assume o papel de um acorde "pivot" no processo de mutação, pois apenas em sua resolução como sexta aumentada obtém-se um acorde de uma nova série.

Outro aspecto omitido por Yellin na definição sobre mutação diz respeito à distância intervalar de terça menor que separa cada série. Desta forma, não é feita uma correlação entre o padrão seqüencial da mutação com a estrutura do acorde diminuto ${ }^{18}$.

No exemplo 42 já é possível observar que, ao integrar a reinterpretação enarmônica com a troca do duplo pedal, apenas uma nota fica mantida enquanto a outra é modificada.

\section{Exemplo 42: A troca das notas do pedal no processo de mutação}

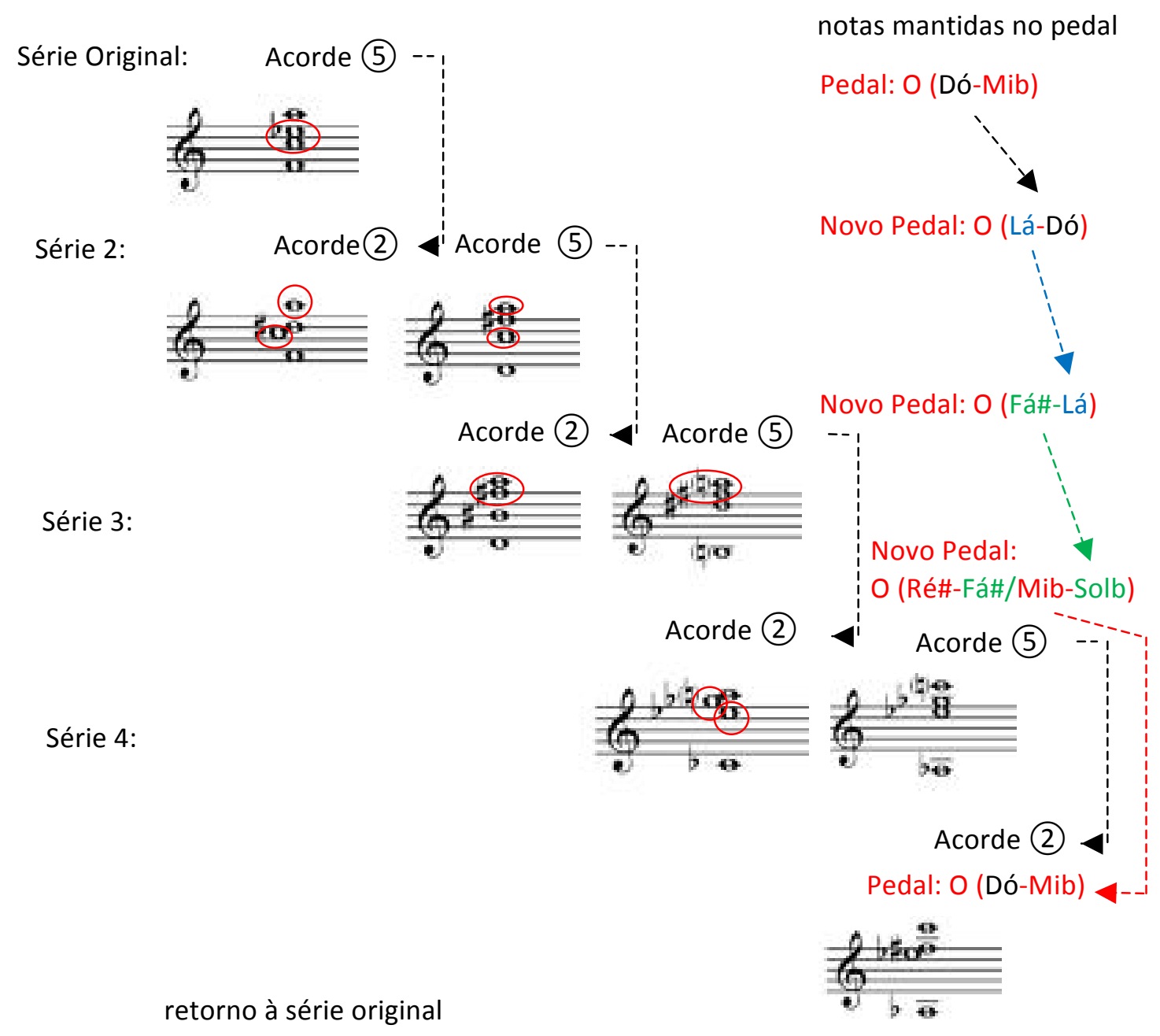

No exemplo 43, as notas constituintes do pedal das séries relacionadas por mutação são novamente apresentadas, de modo que é possível visualizar a formação do acorde diminuto gerador.

${ }^{18}$ Wason (1985, p. 19) e Telesco (1998, p. 260) associam a mutação à estrutura do acorde diminuto. 
Exemplo 43 - Acorde diminuto gerador

Série Original:

Mutações:

Série 2:

Série 3:

Série 4:
Pedal: O (Dó-Mib)

Pedal: O (Lá-Dó)

Pedal: O (Fá\#-Lá)

Pedal: O (Ré\#-Fá\#/Mib-Solb)
Acorde diminuto formado a partir das notas constituintes de cada novo pedal

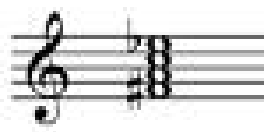

As análises dos exemplos 42 e 43 evidenciam a distância intervalar de terça menor contida entre as séries geradas por mutação, o que confere a esta estrutura o vínculo com o acorde diminuto, e conseqüentemente, sua classificação como de transposição limitada. Assim, trata-se de uma relação simétrica com apenas quatro repetições diferenciadas do padrão (2) (3) (4) (5), isto é, a série original e mais três séries resultantes do processo de mutação (Ex. 44).

\section{Exemplo 44 - A série original e suas três novas séries}

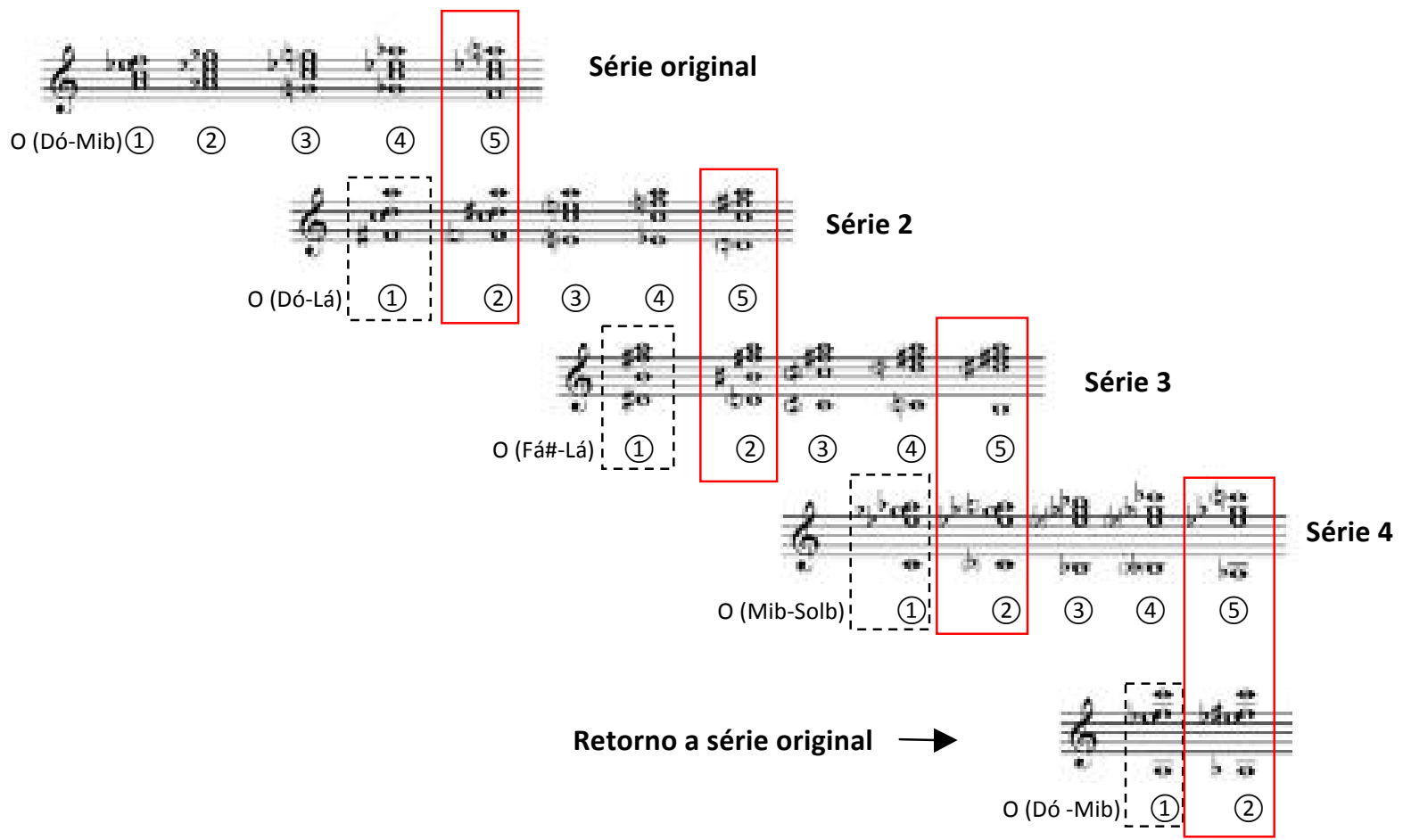

O exemplo 44 mostra as quatro repetições do padrão derivadas de apenas um acorde gerador $\left(\right.$ Fá\# $\left.^{\circ}\right)$. Uma vez que só existem três acordes diminutos diferentes, pode-se concluir 
que há apenas três apresentações diferenciadas de uma série com mutações, nomeadas por Paula Telesco como ciclos do omnibus (Ex. 45). Neste sentido, a autora acrescenta também que:

As dominantes que estão nas duas pontas [desta progressão] tornam claro que os acordes inseridos [na mesma] participam de um prolongamento do $\mathrm{V}$, mesmo que temporariamente eles possam sugerir funções estruturais mais profundas. Mas se uma das dominantes das pontas for removida ou se tornar parte de uma troca de vozes à parte, a progressão perde o seu ancoramento tonal. Isso ocorre quando diversas progressões omnibus em relação de terça menor são mantidas juntas [...] Um ciclo completo, que atravesse uma oitava cromática inteira, requer quatro dessas sobreposições. E uma vez que as notas mantidas como sons comuns, ao longo de um ciclo completo, compreendem um acorde de sétima diminuta, [deduz-se que] há apenas três ciclos possíveis (TELESCO, 1998, p. 259-260).

Exemplo 45 - Os três ciclos omnibus (TELESCO, 1998, p. 261)

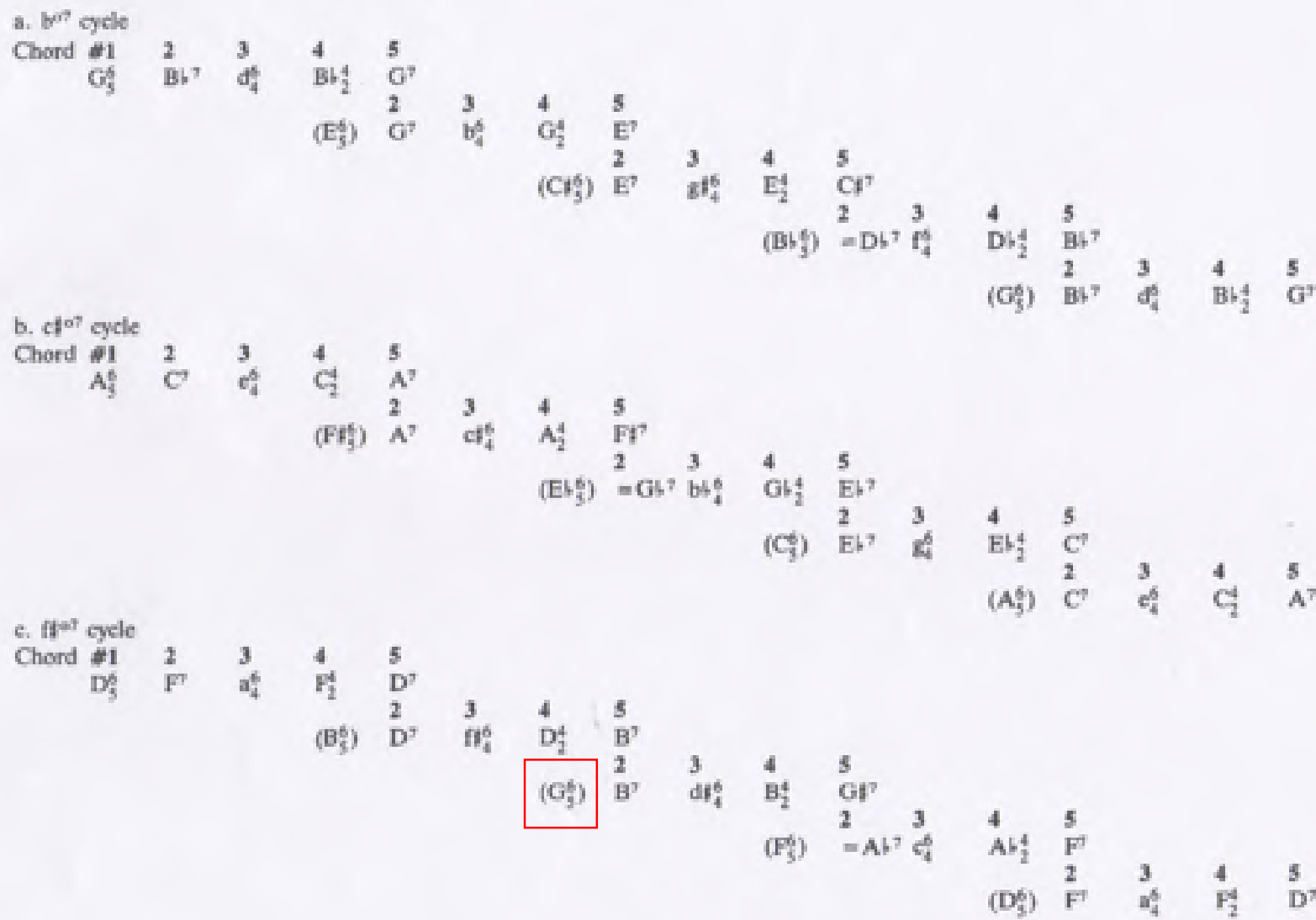

Neste exemplo Telesco utiliza parcialmente a nomenclatura de Yellin, apenas com a indicação dos números arábicos e sem as notas do pedal. Embora fale de apenas quatro apresentações em cada ciclo, é exposto cinco, no entanto sem reforçar que esta última tratase de uma repetição da série de partida. A autora nomeia os três ciclos omnibus que dão 
origem a estrutura: o primeiro $\mathrm{Si}^{\circ}$, o segundo Dó\# ${ }^{\circ}$ e o terceiro Fá\# ${ }^{\circ}$. Contudo, a ordem apresentada por ela, embora correta, não deixa claro ao leitor que o terceiro ciclo nomeado como Fá $\#^{\circ}$ se refere à uma das possibilidades de escrita enarmônica do acorde de Dó ${ }^{\text {, }}$ perfazendo assim a seqüência: $\mathrm{Si}^{\circ}, \mathrm{Dó}^{\circ}$ e $\mathrm{Dó} \#^{\circ}$, as três transposições diferenciadas desta estrutura ${ }^{19}$.

No exemplo 46 é possível observar quatro séries conectadas pelo processo de mutação, o equivalente a um ciclo omnibus. As notas do pedal da série original, associada às outras três, refletem a estrutura do acorde gerador $\mathrm{Si}^{\circ}$.

Exemplo 46 - Scott Joplin: Concert waltz "Bethena", comps. 68 - 75 (YELLIN, 1998, p. 79)
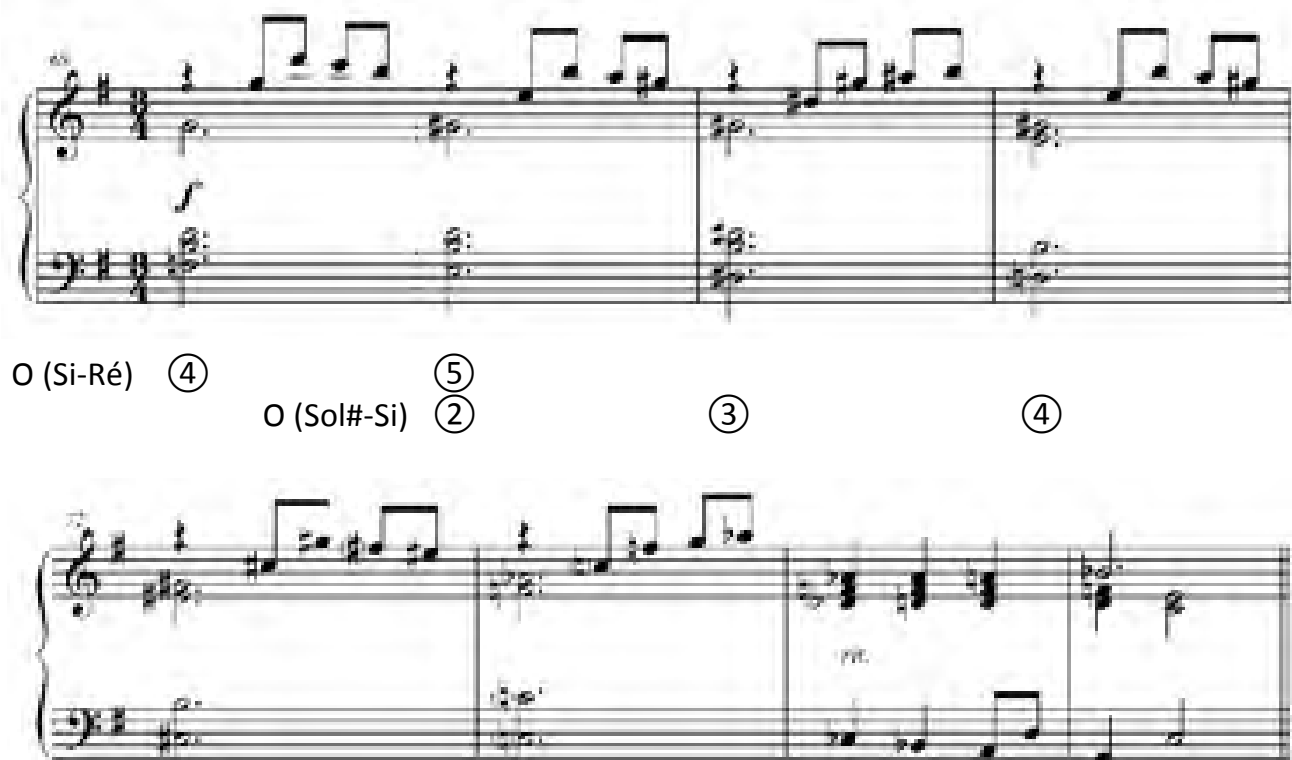

(5)

O (Fá-Láb)(2)

(3)

(4) (5)

O (Ré-Fá) (2)

Ainda neste exemplo fica evidente o uso da mutação em associação com a função de modulação, uma vez que a interrupção no acorde (3) redireciona a música para a tonalidade de Fá maior.

Para finalizar este item, o trecho do primeiro movimento da Sexta Sinfonia de Tschaikovsky (Ex. 47), ilustra, de forma muito similar ao exemplo 46, também quatro séries em

${ }^{19}$ Sobre o quadro apresentado por Telesco no exemplo 45, Dittrich comenta que ocorre um erro de impressão. Assim, no terceiro ciclo, o primeiro acorde da terceira linha deveria ser um deveria um Sol\# maior em primeira inversão com sétima e não Sol maior, como assinalado em vermelho. (DITTRICH, 2007, p. 112, nota 17). 
mutação e com função modulatória. No entanto, a sequência é feita na ordem inversa, ou seja, com o baixo cromático ascendente, em que o padrão: (5) (4) (3) é repetido em relação de terça menor mais quatro vezes. Neste caso, vale lembrar que a reinterpretação é feita com o (2) enarmonizado como (5) da série seguinte.

Exemplo 47 - Tschaikovsky: Sexta Sinfonia Op.74 em Si menor, 10 mov., comps. 259 - 263 Redução para piano (YELLIN, 1998, p. 71)

\section{Allegro vivo}
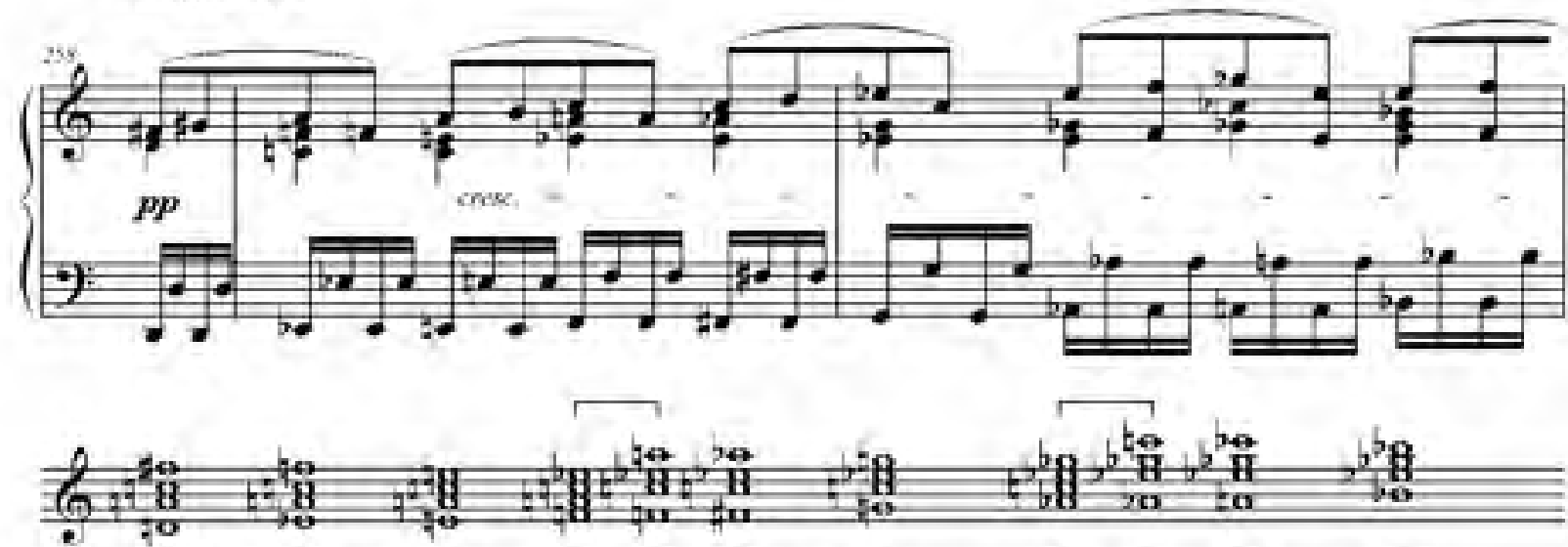
O (Lá-Dó) (5)
(4)
(3)
(2) (5) (4)
(3)
(2)
(5) (4)
O (Mib-Solb)

(3)
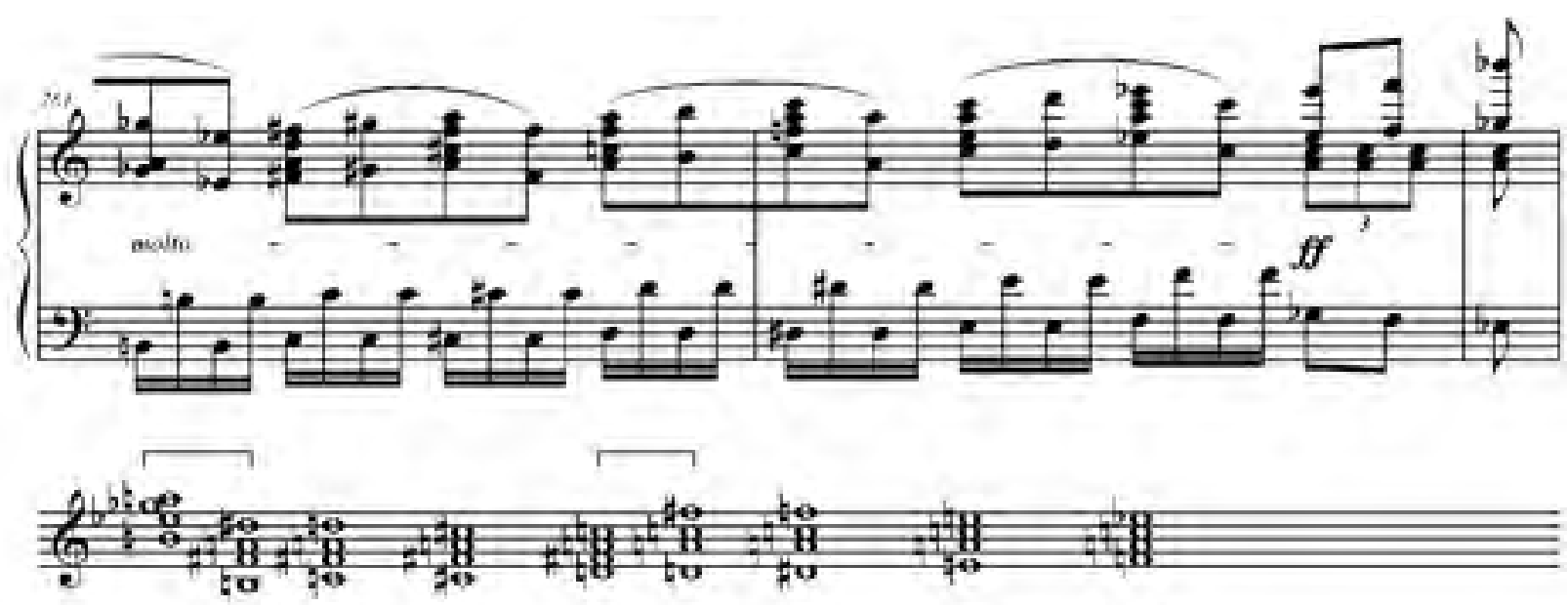

(2) (5) (4)

(3)

(2) (5) (4)

(3)

(2) O (Fá\#-Lá) O (Lá-Dó)

Como observa Yellin (1998, p. 73), a sequência cromática do omnibus neste movimento está vinculada a uma enorme inflexão de dinâmica, uma vez que parte de uma gama sonora em $p p$ para atingir o clímax em $f f$. 


\section{3 - VARIANTES DA PROGRESSÃO OMNIBUS}

[...] na prática, o omnibus não foi uma progressão imutável única, mas uma família de progressões, o que significa que sua presença em uma passagem pode não ser imediatamente óbvia (TELESCO, 1998, p. 244).

A exposição feita inicialmente neste capítulo demonstrou a progressão omnibus em sua forma padrão seguida pelas possibilidades de mutações. No entanto, a expressão "idéia omnibus" utilizada por Yellin no título de seu livro faz alusão a um princípio mais amplo que o padrão clássico. Porém, em nenhum momento o autor define esta nomenclatura e tampouco sua abrangência. Assim, ao se deparar com exemplos musicais em que o padrão clássico não se apresenta de forma literal, ao invés de interpretá-los como outras formas aparentadas da progressão numa referência à idéia omnibus, ele propõe análises nas quais suposições, alterações e substituições de notas são incorporadas, na tentativa de adequar tais passagens ao seu modelo clássico.

Em seu livro, as variantes da progressão omnibus não implicam necessariamente em termos específicos ou numa classificação em categorias, pelo contrário, este conteúdo se encontra disperso nos capítulos e nos exemplos da literatura musical. Sua forma de organização privilegia a vinculação dos modelos cromáticos com o repertório de diferentes gêneros, épocas e estilos, porém o desconhecimento por parte do autor das pesquisas da corrente alemã, e conseqüentemente dos padrões do Teufelsmühle, somados a falta de critério na disposição dos aspectos estruturais podem dificultar a assimilação das inúmeras possibilidades destas sequências.

Portanto, a presente pesquisa entende que a "idéia omnibus" incorpora inúmeras variantes do padrão clássico, que vão desde fragmentações e alterações da série até omissões e substituições de acordes.

Diante de um grande número de apresentações variadas destes modelos cromáticos, da ausência de uma organização estrutural e de uma padronização de nomenclaturas, esta dissertação irá propor o agrupamento de algumas variantes em categorias e a listagem de termos vinculados a cada grupo. Em parte, tal proposta objetiva atender as observações feitas pela pesquisadora alemã Marie-Agnes Dittrich, que constata o seguinte problema: "Não menos confusa do que esse grande número de variantes dos modelos é também a sua ordenação na bibliografia principal" (DITTRICH, 2007, p. 114). 
A seguir, as principais formas de apresentação não literal do padrão clássico citadas em The omnibus Idea, os termos e as cifragens empregadas por Yellin e Telesco, assim como apontamentos críticos e aplicações analíticas no repertório encontram-se divididas nos seguintes tópicos: substituição pelo acorde diminuto, fragmentações, omissões de acordes e alterações da estrutura da série. Cabe aqui salientar que alguns exemplos musicais podem ser classificados concomitantemente em várias categorias e que tais divisões não implicam numa limitação do uso da progressão. Além disso, tais passagens podem ainda conter as mutações discutidas no item 2. 2.

\section{3. 1 - Substituição pelo acorde diminuto}

Neste tópico torna-se indispensável a referência a Vogler, pois seu modelo de harmonização da escala cromática serviu como referencial teórico tanto para a corrente alemã quanto para a americana.

Aqui cabe ressaltar uma importante crítica à Yellin, pois ao se deparar com a substituição de um acorde de dominante com sétima do padrão clássico por um acorde diminuto, o autor não reconhece o vínculo com o modelo cromático de Vogler. Tal situação é considerada por Telesco (2001, p. 132) como um paradoxo, pois embora Yellin aponte a harmonização cromática de Vogler como um possível precursor da progressão omnibus, ele não a identifica em suas análises de exemplos do repertório.

Uma vez que esta troca de tipologias mantém similaridades em diferentes níveis, incluindo a manutenção da função harmônica, Yellin é levado a reconhecer algumas semelhanças entre a harmonização de Vogler (Ex. 48) e o omnibus, tais como as notas do pedal em terça menor e o acorde menor com quarta e sexta. Contudo, o autor descarta a possibilidade do modelo de Vogler ser considerado como omnibus, "[...] devido à mistura de tríades, dominantes com sétimas e acordes diminutos com sétima [...]" (YELLIN, 1998, p. 15 - 16).

Exemplo 48 - Harmonização da escala cromática do Vogler (YELLIN, 1998, p. 15)

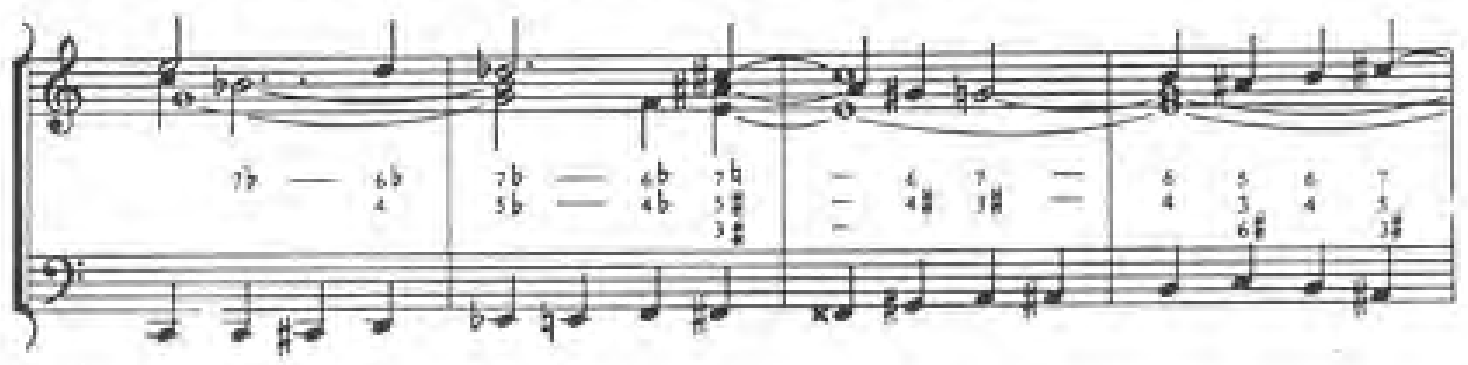




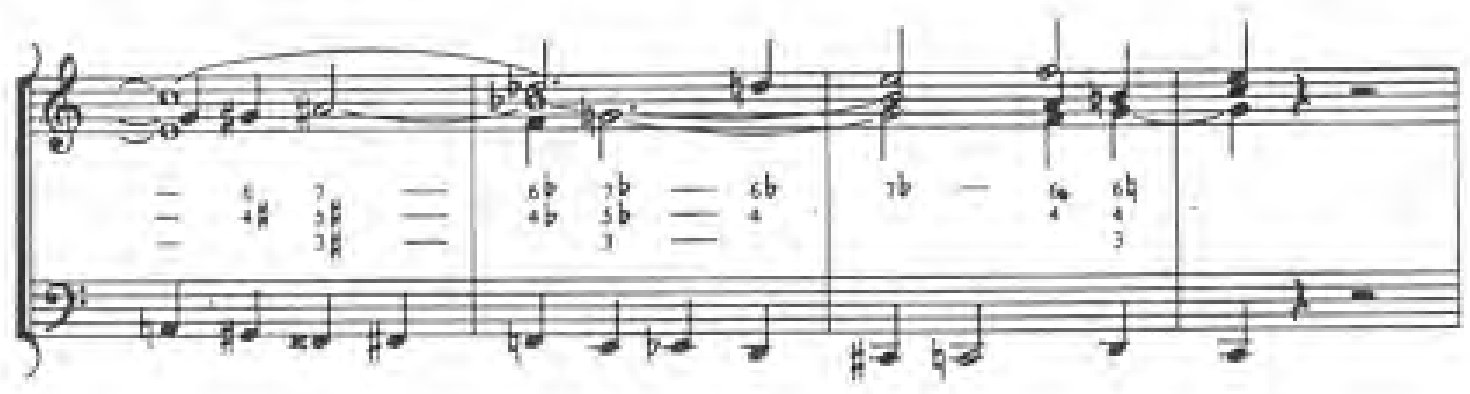

Como pode ser visto no exemplo a seguir, Yellin cifra o acorde diminuto com o símbolo $^{\circ}$ incorporado ao número arábico circulado, numa tentativa de vincular tal substituição ao padrão clássico.

Exemplo 49 - C. P. E. Bach: Rondó no 3 em Ló menor, comps. 142 - 156 (YELLIN, 1998, p. 16)

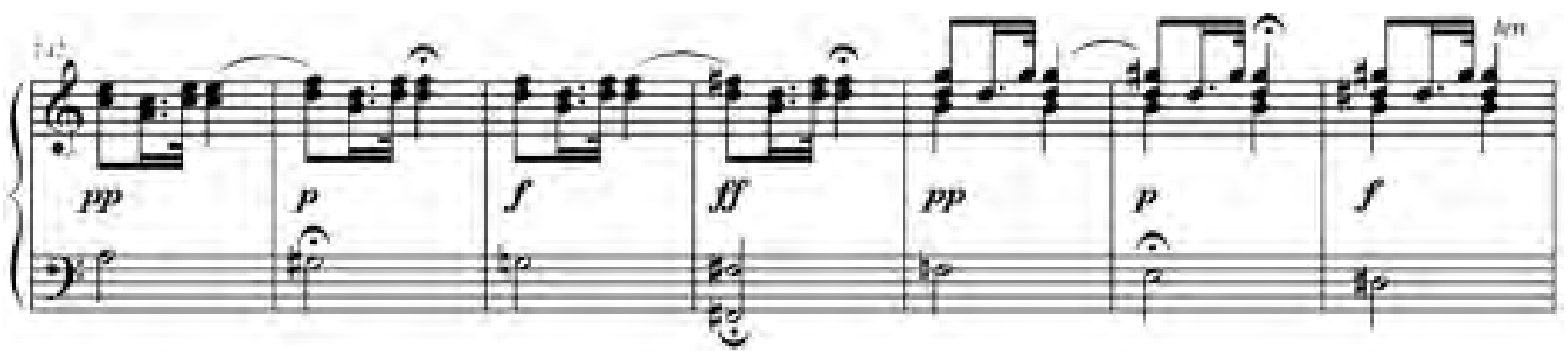
O (Si-Ré) (1) ${ }^{\circ}$
(2)
(3)
(4)
$\mathrm{O}$ (Sol\#-Si)
(5)
(2)

(3)

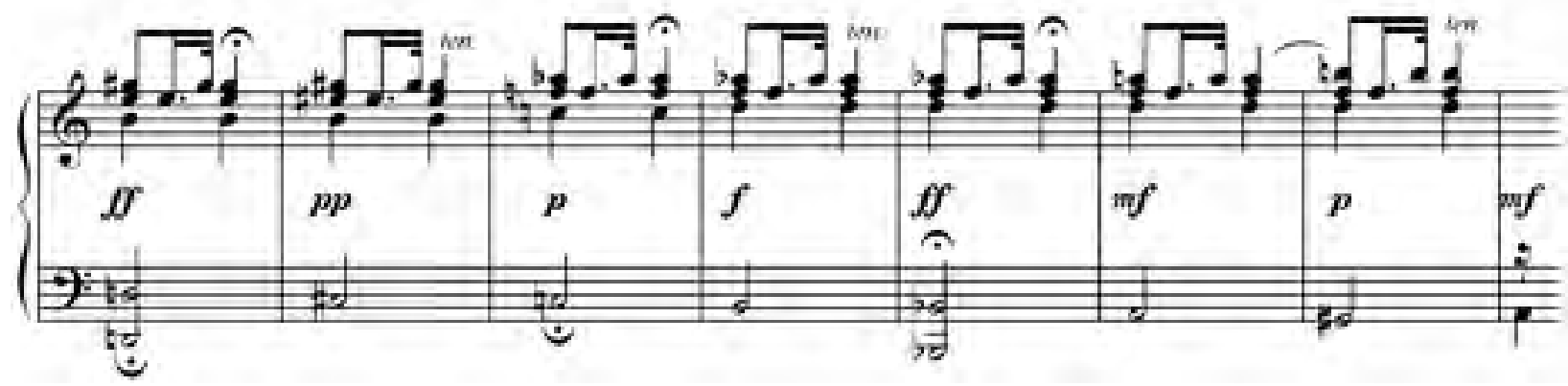

(4)

(5)

O (Mil\#-Sol\#) (2) [Fá-Láb]

(3)

(4) O (Ré-Fá) (2)

(3)

(4) ${ }^{\circ}$

O americano utiliza neste rondó o símbolo do diminuto no acorde (1) do compasso 143 e no (4) ${ }^{\circ}$ do compasso 155 , mas inexplicavelmente não o faz no acorde (4) ${ }^{\circ}$ do compasso 152. Telesco aponta algumas inconsistências de Yellin na identificação deste sinal, como pode ser verificado no exemplo acima, bem como em vários outros exemplos em The Omnibus Idea. 
Daí a insatisfação da autora ao identificar a progressão com a substituição pelo diminuto em inúmeros exemplos analisados por Yellin sem tal reconhecimento ${ }^{20}$. A autora então acrescenta que tal postura:

[...] é parte de um problema mais amplo em termos de consistência da identificação, que às vezes eu acho confusa e frustrante. Em alguns momentos Yellin sustenta um exemplo musical com os modelos omnibus e coloca entre colchetes a nota ou notas do modelo que estão faltando na passagem atual ao invés de indicar a substituição de um acorde diminuto [...] (TELESCO, 2001, p. 132).

Em suma, é comum encontrar nas análises realizadas por Yellin passagens que utilizam o acorde diminuto e que, entretanto, são assumidas pelo autor como pertencentes ao padrão clássico ao invés de formas próximas e aparentadas. No caso do Rondo em Lá menor do exemplo 49, talvez uma interpretação como Teufelsmühle seja mais adequada (Cf. Ex. 11), pelo fato de reproduzir exatamente as versões A e B de Seidel.

Em contrapartida, Paula Telesco vincula a substituição do acorde diminuto com o modelo da harmonização da escala cromática de Vogler e nomeia este tipo de progressão como Vogler/ omnibus (1998, p. 264) ${ }^{21}$. Resumidamente a autora aponta que:

A única diferença entre as duas progressões [de Vogler e o padrão clássico] é que onde quer que o omnibus contenha uma dominante com sétima no baixo [acorde (4) do padrão clássico], a progressão de Vogler contém um diminuto com sétima [...] (TELESCO, 2001, 132).

\subsection{2 - Fragmentações}

Sob este título encontram-se relacionadas possibilidades de fragmentação da progressão omnibus ou Vogler/omnibus por meio da interrupção a qualquer momento da série. As variantes, neste item, podem conter no mínimo três acordes sucessivos de uma progressão, como ilustram as passagens a seguir.

O primeiro exemplo deste tópico é o Noturno Op. $55 n$ o 2 de Chopin, em que são encontrados quatro acordes da série no padrão clássico na disposição: (5) (4) (3) (2). 0 fragmento da série no compasso 17 inicia com o acorde de Si bemol maior com sétima

${ }^{20}$ Cf. Telesco (2001, p.130 e seguintes). Dittrich também concorda com a pesquisadora americana e aponta que são imprecisas muitas das análises de Yellin, cf. (DITTRICH, 2007, p. 110).

${ }^{21}$ O Vogler/omnibus passa a ser considerado pelos americanos como uma variante da progressão omnibus, o que corresponde à classificação proposta por Seidel como Teufelsmühle versão A. 
menor, dominante do tom. A interrupção no compasso 19 ocorre com a ausência do primeiro acorde da série, que em seu lugar é empregado o acorde de Sol maior com sétima menor, dominante de Dó menor (vi). Aqui Chopin explora a progressão de forma elaborada ${ }^{22}$, com a linha cromática descendente do omnibus distribuída na mão esquerda com deslocamentos rítmicos.

Exemplo 50 - Chopin: Noturno Op. 55 no 2, comps. 16 - 21

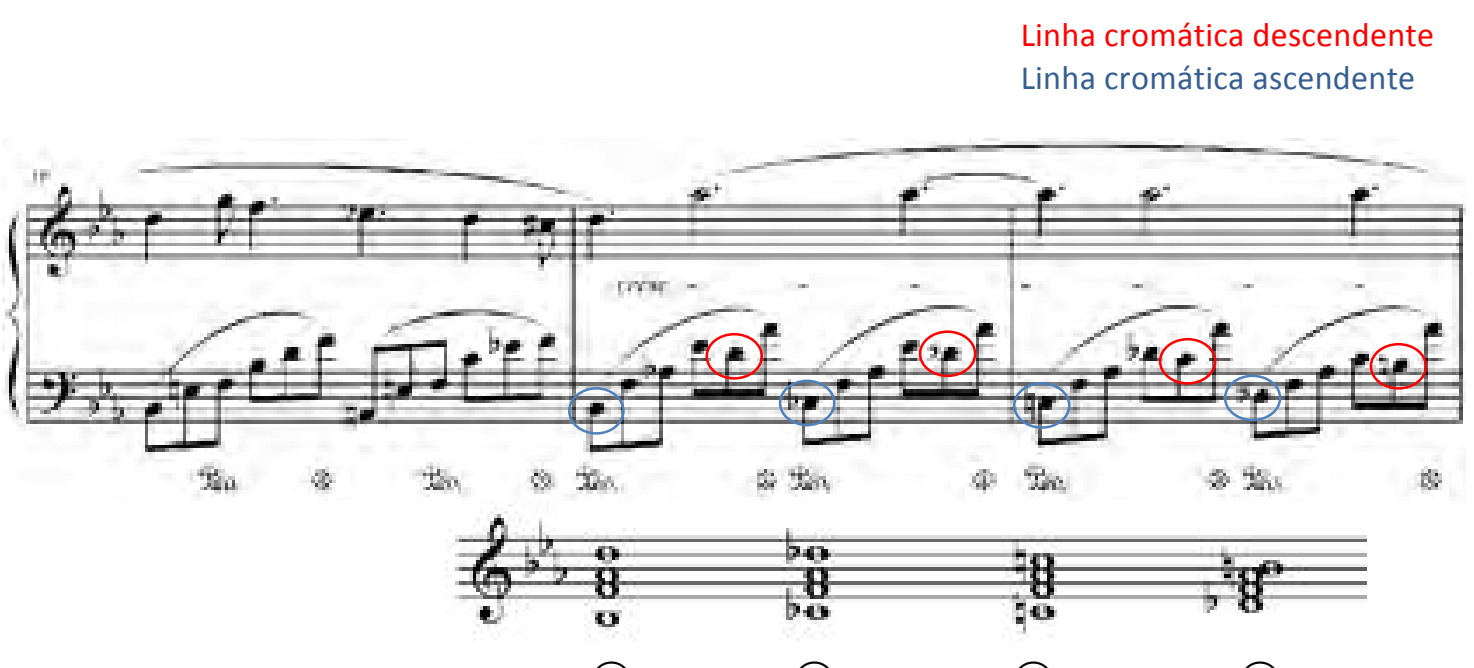

Interrupção da série

(4)

(3)

(2)

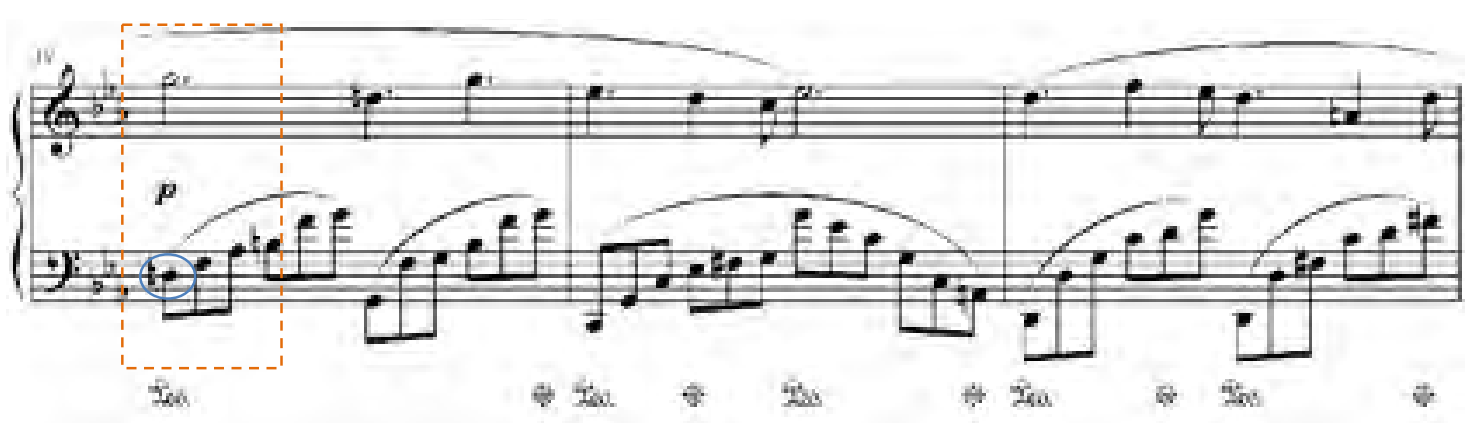

Este trecho sem o primeiro acorde da série também permite uma classificação como Teufelsmühle, mais especificamente a versão $\mathrm{B}$, pelo fato da correspondência com as tipologias descritas por Seidel.

Outra possibilidade de fragmentação envolve a apresentação de quaisquer três acordes consecutivos da série. Entretanto, apenas as sequências (2) (3) (4) ou (4) (3) (2) são consideradas e denominadas por Telesco como small omnibus ${ }^{23}$ (Ex. 51). Neste caso, a

\footnotetext{
${ }^{22}$ Tal característica da linguagem composicional de Chopin irá receber especial atenção na segunda parte deste trabalho.

${ }^{23}$ Cf. Telesco (1998, p. 258).
} 
autora enfatiza a troca de vozes entre $\mathrm{V}^{7}$ e $\mathrm{V}^{2}$ e ressalta que o acorde menor com quarta e sexta figura apenas como passagem, ou seja, como um acorde não funcional.

Exemplo 51 - Haydn: Sinfonia no 98, 40 mov., comps. 270 - 275 (TELESCO, 1998, p. 259)

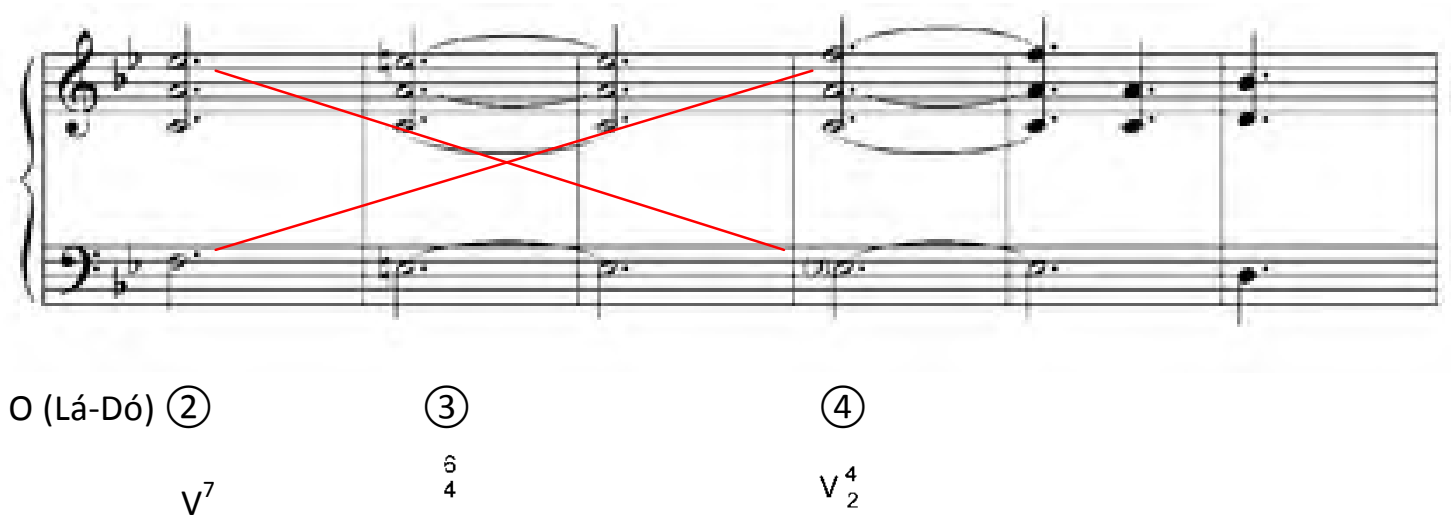

Entretanto, esta designação small omnibus proposta por Telesco é refutada pela pesquisadora alemã Dittrich, que argumenta:

Naturalmente, acordes de sensíveis para acordes menores com quarta e sexta de passagem (que Thorau chama de perífrase de troca de vozes na dominante), ocorrem também em cadências normais, sobretudo em cadências em menor. Por isso, a designação small omnibus para tais fragmentos de cadência, como vemos, por exemplo, em Telesco (página 259), parece algo não convincente. (DITTRICH, 2007, p. 115).

\subsection{3 - Omissões e repetições de acordes}

É importante destacar que este item não deve ser confundido com o de fragmentações, em que a série não está completa e todos os acordes obrigatoriamente se dispõem de forma consecutiva. A diferença aqui é a possibilidade dos acordes não ocorrerem de tal maneira, uma vez que qualquer um deles poderá será omitido, muito embora a sequência continue.

Como mencionado, a divisão em itens desta pesquisa não é excludente, ou seja, um mesmo exemplo poderá conter fragmentação, omissão de acordes e mutação concomitantemente, como ocorre no trecho a seguir, retirado do Lied Meeres Stille de Schubert (Ex. 52). Um fragmento da progressão omnibus é evidente no início da segunda estrofe da parte instrumental nos compassos 17 a 20. As notas Lá e Dó formam o duplo 
pedal nas vozes internas enquanto que a inversão cromática simétrica é colocada nas vozes extremas, formando a série (2) (3) (4) (5). A mutação ocorre no compasso 20 , em que o acorde (5) encontra-se reinterpretado como (2) de uma nova série, O (Fá\#-Lá). Por fim, a passagem é também marcada pela omissão do acorde (4) desta nova série no compasso 22 , como é possível constatar na comparação entre os exemplos 52a e 52b.

Exemplo 52 - Schubert: Lied Meeres Stille

a) Trecho original: comps. 17 - 24

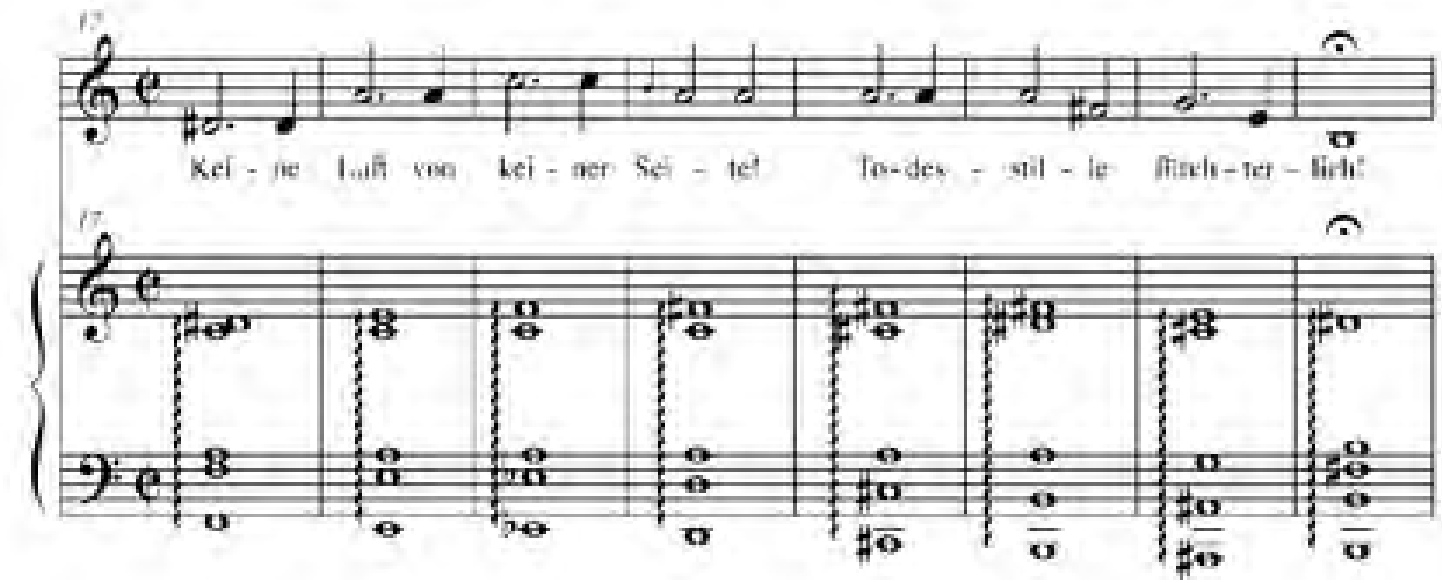

O(Lá-Dó) (2)

(3)

(4)

(5)

O(Fá\#-Lá) (2)

(3)

(5)

b) Passagem com inserção do acorde (4): comps. 20 - 24

compasso extra:

(b) Passagem com inserção do acorde (4): comps. $20-24$ acorde omitido no trecho original

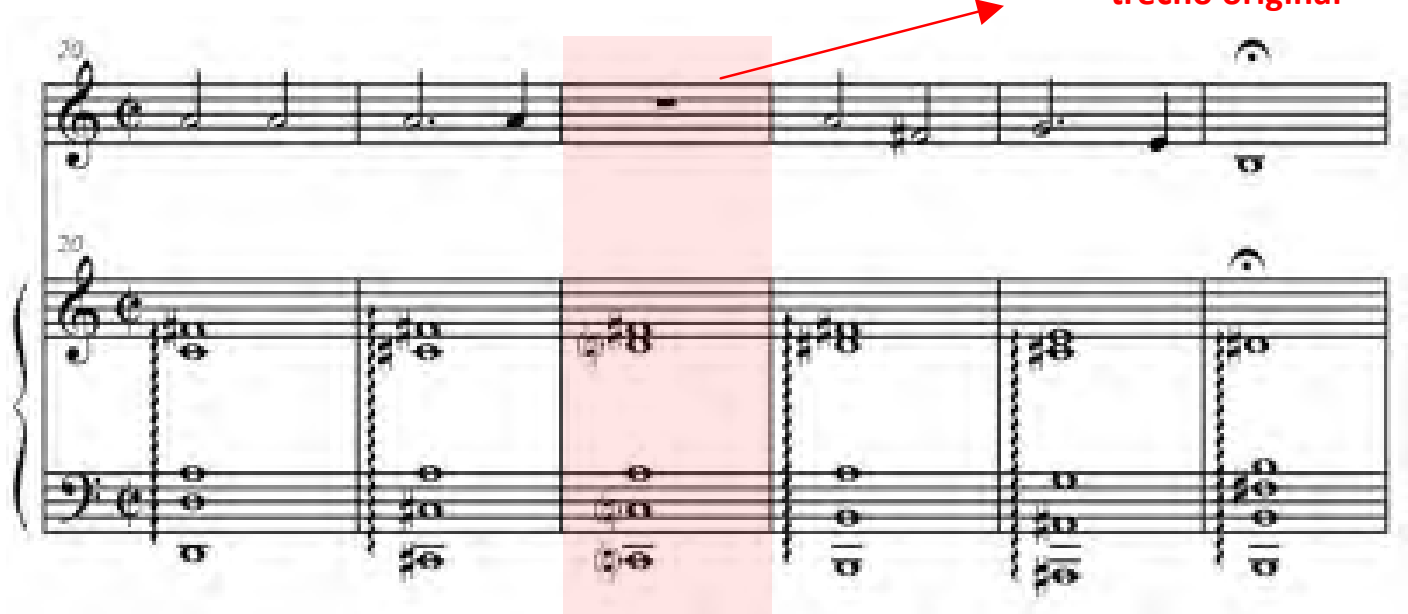

O(Lá-Dó) (5)

O(Fá\#-Lá) (2)

(3)

(4)

(5) 
Tal omissão e ruptura da progressão omnibus suscita algumas questões que podem estar associadas ao plano tonal, a simetria dos versos e ao vínculo do poema com a estrutura musical. Neste sentido, cabe ressaltar que a omissão de acordes foi um procedimento usualmente empregado por Schubert, conforme afirma Dittrich: "em outros Lieder, nos quais Schubert emprega o Teufelsmühle na forma estrófica, acontece da mesma forma" (DITTRICH, 2007, p. 107, nota 3).

Por outro lado, é possível interpretar a passagem exposta no exemplo 52a novamente como Teufelsmühle versão B. Além disso, vale destacar que os modelos cromáticos neste Lied intensificam a dramaticidade do conteúdo poético, que reflete o medo e a ideia da morte contida no texto de Goethe: "Nenhuma brisa de nenhum lado! Temeroso silêncio mortal!".

Outro aspecto a ser tratado diz respeito à repetição de acordes, recurso que poderá ocorrer a qualquer momento da série, como pode ser constatado no exemplo a seguir, extraído da ópera Robert le Diable de Meyerbeer, ato 1, cena 6.

Exemplo 53 - Meyerbeer: Robert le Diable, comps. 310 - 318 (YELLIN, 1998, p. 34)

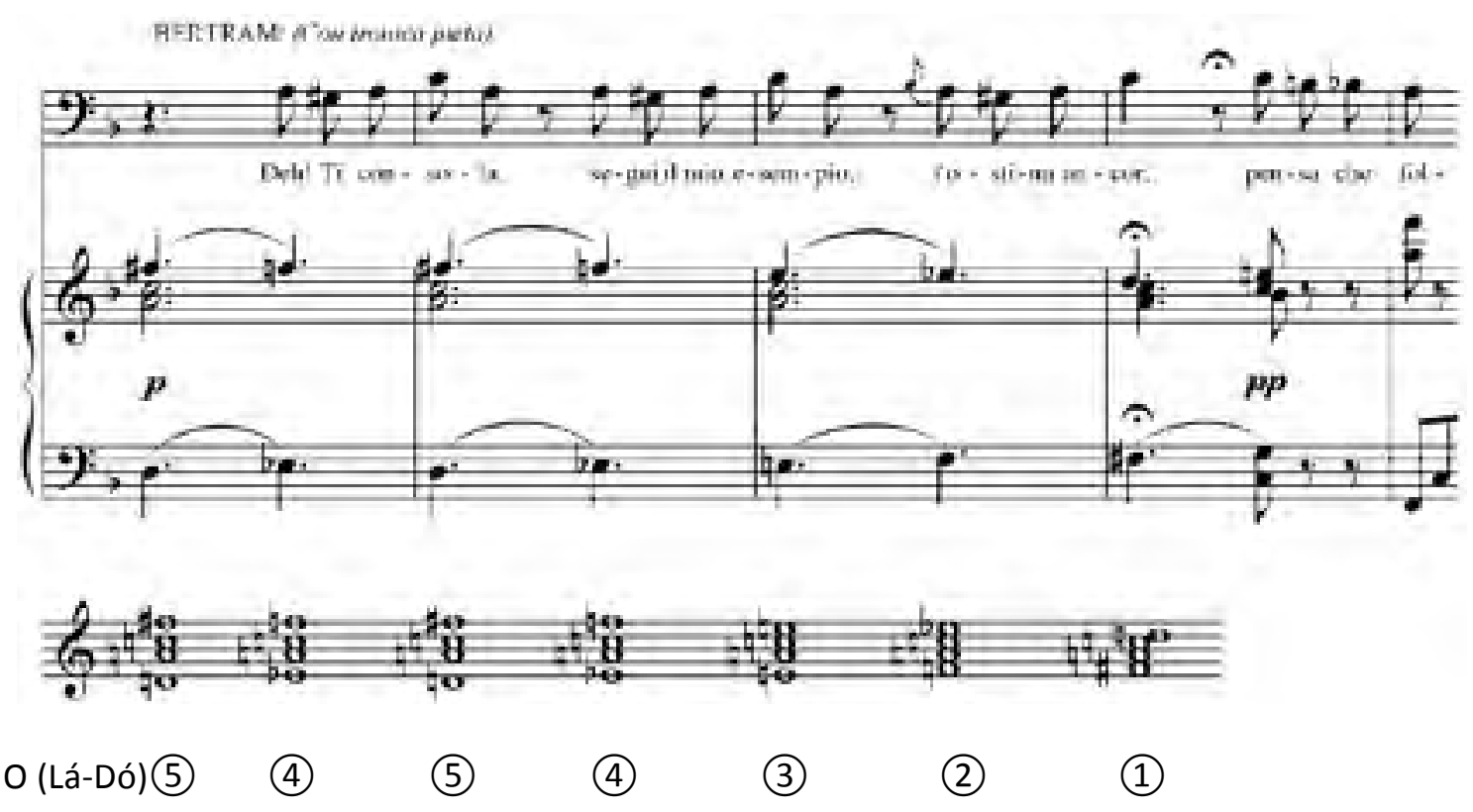

A análise da passagem do exemplo 53 revela o emprego da versão retrógrada da série e a repetição dos acordes (5) e (4) que precede a apresentação completa do padrão clássico. Além disso, pode-se observar que a linha da voz é constituída apenas pelas notas do 
duplo pedal (Lá-Dó), enquanto que na parte do piano são encontrados o cromatismo nas vozes extremas e o duplo pedal nas vozes intermediárias ${ }^{24}$.

\section{3. 4 - Alterações na estrutura da série}

Neste tópico serão tratados vários tipos de variantes, na tentativa de abarcar um maior número de exemplos musicais que preservam a sonoridade desta progressão, mas que, entretanto, não se sustentam em categorias independentes. Assim, serão comentados os seguintes casos: alteração no acorde (3), ausência de uma das linhas cromáticas e omissão de notas do pedal.

\section{- Alteração no acorde (3)}

Uma variante possível e freqüentemente encontrada no repertório musical diz respeito ao acorde (3) do padrão clássico, que permite ser empregado com a alteração para um acorde maior com quarta e sexta ao invés do usual menor também com quarta e sexta, o que implica apenas em uma única nota diferente em relação ao modelo de Yellin.

O trecho musical escolhido para ilustrar tal alteração foi extraído do Lied Schliesse mir die Augen beide das Canções de Juventude de Alban Berg, passagem que se torna apropriada neste momento pelo fato de também empregar recursos expostos anteriormente, como fragmentação e repetição de elementos da série. Trata-se de uma peça com apenas nove compassos na tonalidade de Dó maior que traz, nesta versão tonal de $1901^{25}$, a idéia omnibus em dois momentos distintos: na abertura do Lied (comps. 1-2) e no final (comps. 7-8).

Assim, o exemplo 54 ilustra a primeira aparição nesta peça, que ocorre na versão retrógrada, com fragmentação e com a repetição dos acordes (3) e (2) no final da primeira frase. Especial atenção deve ser dada para a alteração da nota Mib para Mi natural do acorde (3). O caminho mais previsível seria, de acordo com o padrão do omnibus, a nota Mib como parte do acorde com quarta e sexta no modo menor. Fato reforçado estruturalmente pela presença da nota Láb no compasso 2.

\footnotetext{
${ }^{24}$ Assim, repetições de acordes são comumente encontradas no repertório musical, conferir exemplo 34 do item 2.1, em que ocorre a repetição dos acordes (1) e (2) nos compassos 34 e 35.

${ }^{25}$ Berg fez uma versão atonal para este mesmo texto de Theodor Storm.
} 
Exemplo 54 - Berg: Schliesse Mir Die Augen Beide, comps. 1 - 2

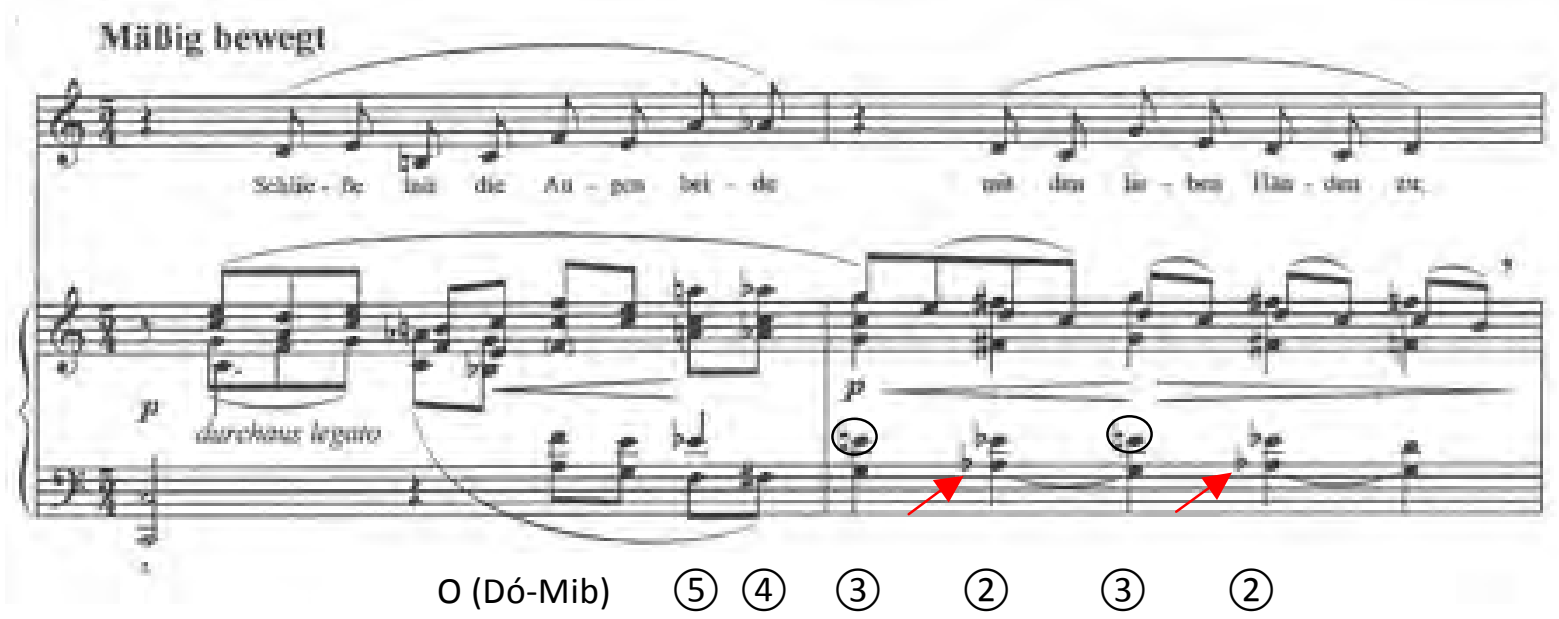

Contudo, a entrada do acorde (3) alterado no compasso 2 causa uma mudança de timbre e uma sensação de mistura de modos, reforçada ainda pela indicação de piano súbito, muito embora a tonalidade da peça seja Dó maior.

- Ausência de uma das linhas cromáticas

Os termos implied e half omnibus ${ }^{26}$ são utilizados esporadicamente por Yellin para referir-se às séries em que a linha cromática no baixo e o duplo pedal são mantidos enquanto que a outra linha cromática está ausente, como pode ser observado a seguir (Ex. 55).

Exemplo 55 - Rossini: William Tell, abertura, comps. 455 - 457 (YELLIN, 1998, p. 33)

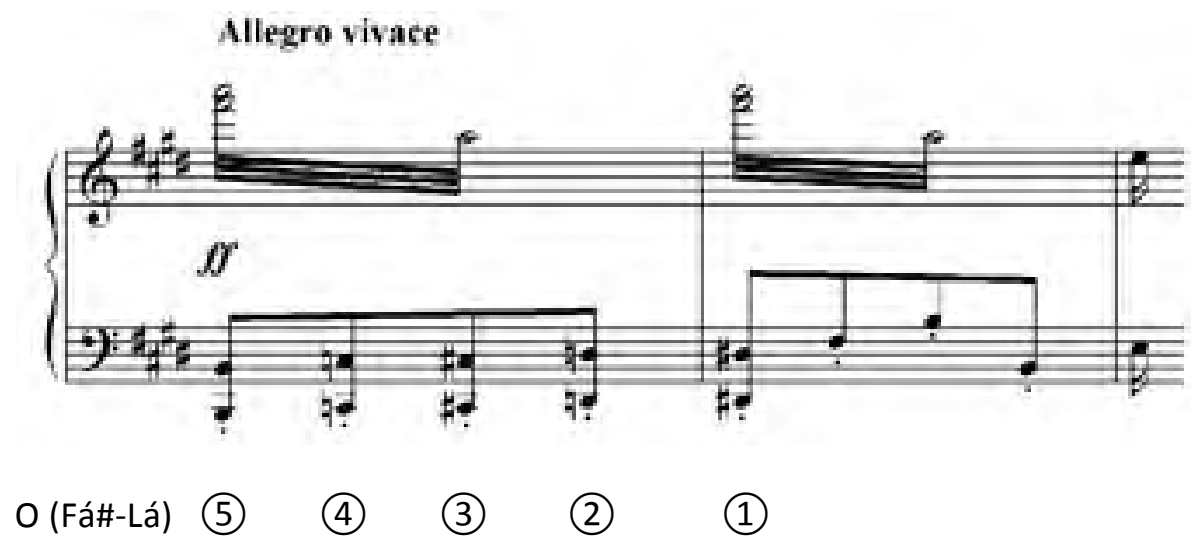

${ }^{26}$ Cf. Yellin (1998, p. 32 e p. 37). 


\section{- Omissão de uma das notas do pedal}

O último aspecto a ser comentado se refere aos exemplos em que as linhas cromáticas sustentam a sonoridade da progressão omnibus e apenas uma das notas do duplo pedal está ausente. O exemplo 56 ilustra o trecho final (comps. $67-74$ ), do Lied Wegweiser de Schubert na tonalidade original de Sol menor.

Exemplo 56 - Schubert: Der Wegweiser do ciclo Winterreise, comps. 67 - 74
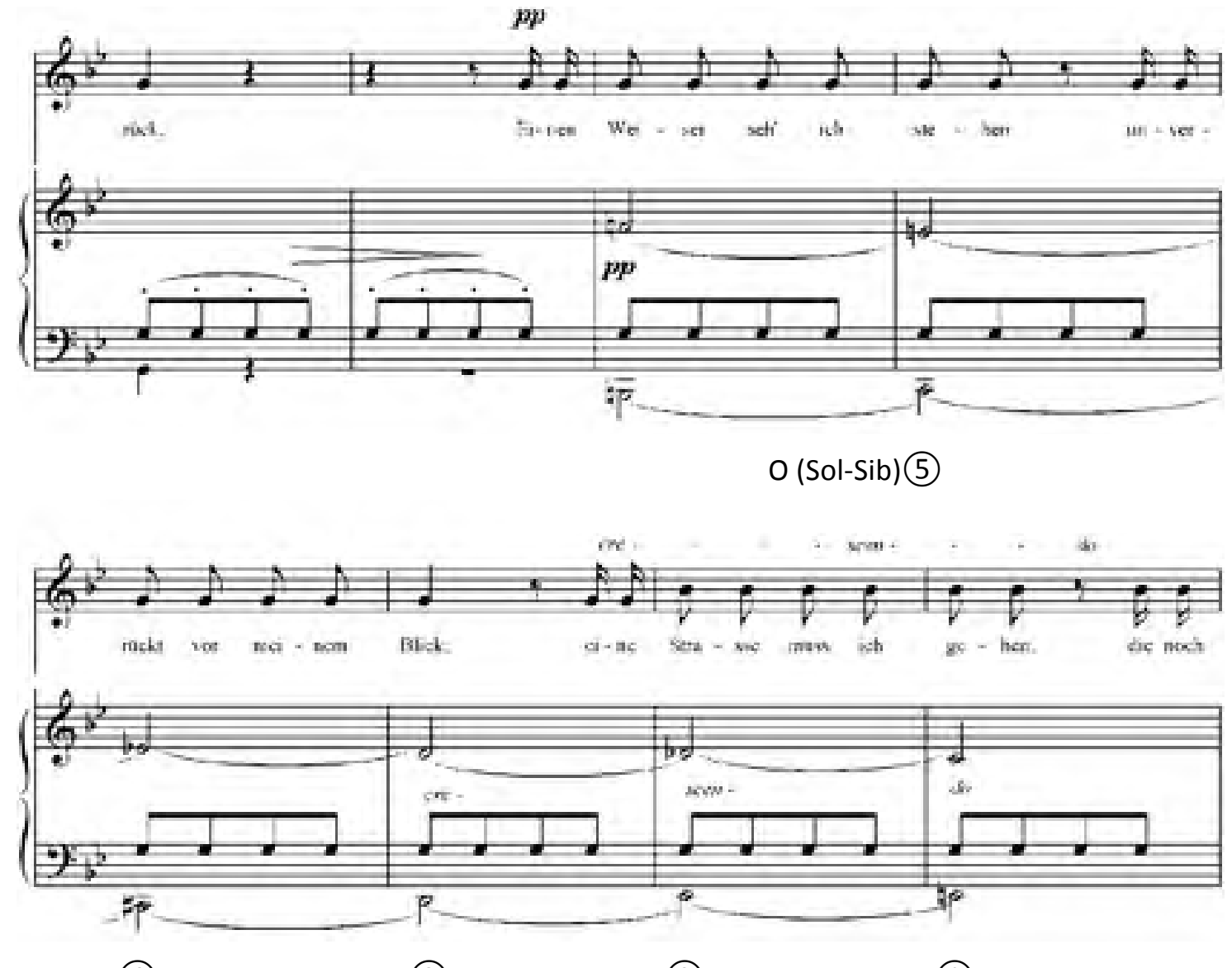

(4)

(3)

(2)

(1)

$\mathrm{Na}$ versão retrógrada, este exemplo apresenta as cinco tipologias previstas na progressão clássica, no entanto, ocorre que uma das notas do pedal (Sib) está omitida nos acordes (5) (4) (3), de forma que é introduzida apenas nos compassos 73 e 74 para completar os acordes (2) e (1). Vale ainda identificar que a parte da voz, por toda a passagem, é composta exclusivamente pelas notas Sol e Sib que compõe o pedal da progressão. 
TEUFELSMÜHLE E OMNIBUS NA PRÁXIS COMPOSICIONAL DE CHOPIN: uma amostragem em diferentes gêneros
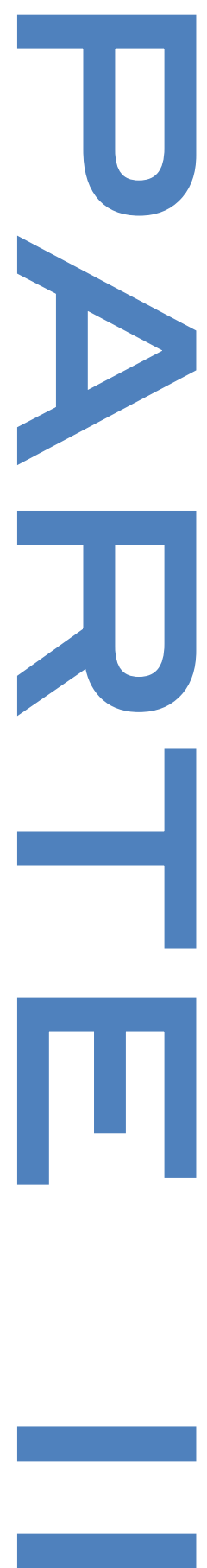


\section{CAPÍTULO 3}

\section{Usos e sonoridades características}

As sequências do Teufelsmühle e omnibus possuem uma longa história e ocupam lugar em obras de diferentes gêneros e períodos musicais. De forma geral, pode-se entender que tais estruturas receberam tratamentos diferenciados, de acordo com a época em que estava inserida. Algumas exposições sobre o uso destas progressões na prática de determinados compositores são encontradas em textos de autores tais como: Paula Telesco, que possui relevante pesquisa sobre estas estruturas no período clássico; Elmar Seidel, que promove um estudo mais aprofundado destas sequências na música de Liszt; e Marie-Agnes Dittrich, que apresenta discussões sobre o Teufelsmühle e omnibus em Lieder de Schubert ${ }^{1}$. Estas investigações específicas permitem observar e refletir sobre as transformações que estes modelos naturalmente sofreram ao longo do tempo.

No caso de Chopin, foi possível constatar que sua música encontra-se permeada com as sequências do Teufelsmühle/omnibus e suas ocorrências figuram em diferentes gêneros musicais escritos pelo compositor polonês. Os modelos estão presentes tanto em peças para piano solo ${ }^{2}$ quanto em obras de câmara ${ }^{3}$, de modo que os inúmeros exemplos abrangem desde o Op. 1, o Rondo em Dó menor, até a última música escrita pelo compositor, a Mazurka Op. 68 no 4.

Ocorre que estas progressões nem sempre são facilmente identificadas em Chopin, devido ao seu sofisticado tipo de escrita, que envolve principalmente: variadas organizações de alturas e dissimulações por meio de figurações melódicas; uso exacerbado de cromatismos; e deslocamentos rítmicos ${ }^{4}$. Nesta ótica, a citação a seguir confirma este ponto levantado:

\footnotetext{
${ }^{1}$ DITTRICH, Marie-Agnes. Harmonik und Sprachvertonung in Schuberts Liedern. Hamburg: Karl Dieter Wagner, 1991, p. 220 - 227.

2 Os exemplos ocorrem em valsas, mazurkas, prelúdios, estudos, noturnos, baladas, rondos, sonatas, improvisos, polonaises, entre outras.

${ }^{3}$ Entre estas composições destacam-se os concertos para piano e orquestra, a Sonata Op. 65 para violoncelo e piano, o Trio Op. 8 e as canções.

${ }^{4}$ Maiores esclarecimentos sobre este tipo de escrita serão demonstrados adiante, em diversos exemplos da obra do compositor.
} 
É evidente que o modelo do Teufelsmühle ou omnibus é auditivamente mais perceptível quando suas sequências harmônicas não são dissimuladas por meio de uma condução de vozes e rítmica complicadas, e quando a atmosfera favorece a tonalidade principal e aquelas mais próximas a ela. No século XIX, quanto mais todos esses pressupostos mudam e quanto mais o Teufelsmühle, por sua vez, deve ser variado para não se enrijecer em clichê, tanto mais difícil se torna percebê-lo como evidente - ou realizar análises que acreditam detectar a ele ou ao omnibus (DITTRICH, 2007, p. 119).

Nesta perspectiva, pontos decisivos sobre a música do compositor polonês são precisamente ressaltados na citação a seguir, extraída do artigo "Ambigüidade $e$ reinterpretação em Chopin" de E. T. Cone:

[...] a música de todos os compositores muito conhecidos sofre os efeitos da superexposição, mas o caso de Chopin é exacerbado. A familiaridade embotou nossa apreciação (algumas vezes até bloqueou nossa recognição) de uma das características primárias de seu estilo: a ambigüidade que permeia todos os níveis de seu pensamento musical (2006, p. 140).

Esta reflexão feita por Cone remete a seguinte questão: Será que uma familiaridade com a música de Chopin implica automaticamente no reconhecimento de tais ambigüidades mencionadas? A ambigüidade tonal em especial, aspecto comumente encontrado na obra do compositor, é um fator primordial e diretamente associado ao objeto desta pesquisa, uma vez que os modelos cromáticos do Teufelsmühle e omnibus carregam tal característica, mais especificamente as reinterpretações enarmônicas de acordes e as reorientações cadenciais ${ }^{5}$.

Outro ponto fundamental da linguagem de Chopin, com implicações diretas na identificação das passagens com o Teufelsmühle ou omnibus, diz respeito ao seu modo original em lidar com a polifonia. A forma criativa e diferenciada com que o mestre polonês faz o tratamento das vozes é expressa por Charles Rosen na colocação a seguir:

[...] uma independência latente de cada voz, consistente e contínua, que poderia irromper em uma total independência a qualquer momento. Essa independência latente corresponde, contudo, senão à teoria, à experiência da audição do contraponto. Em Chopin, as vozes só adquirem total independência quando o ouvinte deseja ter consciência delas: em qualquer outra hipótese, elas permanecem soterradas em uma textura aparentemente homofônica (2000, p. 486 - 487).

\footnotetext{
5 Este termo empregado por Cone diz respeito a um tipo de ambigüidade que, por meio de alterações na estrutura fraseológica, promove um novo direcionamento harmônico (2006, p. 150).
} 
Num primeiro momento a textura pode sugerir que se trata apenas de uma melodia acompanhada, no entanto, freqüentemente a mão esquerda não representa apenas uma função de acompanhamento, pelo contrário, possui um tipo de polifonia com um elevado grau de elaboração, principalmente no que diz respeito à organização das alturas e ao tratamento do cromatismo. Sobre este tipo de escrita, característica da linguagem de Chopin, o compositor brasileiro Willy Corrêa de Oliveira comenta que:

Essa peça [referindo-se ao Prelúdio Op. 28 no 4 de F. Chopin] dá uma idéia de polifonia que não é uma melodia acompanhada. $O$ que isso quer dizer? Quer dizer que, onde havia um modelo concreto (melodia acompanhada), se tem algo diferente. Chopin está indicando para uma característica essencialmente musical [a polifonia] e, Chopin ter trazido essa idéia, é uma das razões de o estudarmos hoje $[\ldots](2005, \text { p. } 11)^{6}$.

Segundo Oliveira, a originalidade do compositor polonês diz respeito também à idéia de criar "uma melodia que não é uma melodia", ou seja, Chopin muitas vezes constrói uma linha melódica de forma a produzir um efeito contrário à sua natureza, como algo estático 7 . Isto ocorre freqüentemente em sua obra, incluindo também as passagens com os modelos do Teufelsmühle e omnibus, como será demonstrado adiante.

Desta forma, esta pesquisa assume como pressuposto a necessidade desta consciência em relação às particularidades da prática composicional de Chopin, para que se desenvolva um estudo mais minucioso, capaz de abarcar e relacionar a escrita polifônica do compositor com o emprego destas fórmulas cromáticas tão antigas.

Portanto, com o objetivo de facilitar a familiaridade com estas estruturas e promover uma reflexão sobre a presença e emprego do Teufelsmühle e omnibus na música de Chopin, a seguir serão expostos alguns usos e sonoridades características, com uma organização em três principais tópicos: andamento, fragmentos e variantes.

\footnotetext{
${ }^{6}$ Um importante documento sobre o pensamento do compositor encontra-se nos anexos da dissertação "Willy Corrêa de Oliveira: por um ouvir materialista histórico" de Alexandre Ulbanere. Trata-se de uma transcrição de todas as aulas lecionadas por Corrêa nos seis anos do curso de composição do Departamento de Música da Escola de Comunicações e Artes da Universidade de São Paulo.

${ }^{7}$ O exemplo do Prelúdio Op. 28 no 4 citado por Corrêa ilustra com clareza este aspecto: a voz aguda é mantida com a nota Si enquanto que a mão esquerda, em acordes, é tecida de forma polifônica. Em suma, o que parece ser uma melodia não é uma melodia e o que parece ser um acompanhamento não é um acompanhamento, na perspectiva do professor Willy Corrêa.
} 


\section{1 - ANDAMENTO}

Um elemento musical que pode, em alguns casos, interferir no reconhecimento destes modelos cromáticos é o andamento. Uma passagem rápida, por exemplo, associada a uma polifonia elaborada, pode de fato dificultar a identificação do Teufelsmühle ou omnibus.

Um exemplo que ilustra este ponto pode ser observado no Estudo Op. 25 no 11 (comps. 17 - 19), em que ocorre a progressão omnibus O (Sol-Sib) na versão retrógrada: (5) (4) (3) (2) (1). Neste caso, por se tratar de uma peça muito virtuosística em um andamento rápido (Allegro con brio), a sequência tende a ser classificada genericamente como uma passagem cromática, como observa Yellin (1998, p. 52). Com exceção do cromatismo ascendente (Dó, Dó\#, Ré, Mib, Mi natural), a figuração da mão direita contém todas as notas do padrão clássico: cromatismo descendente (Mi, Mib, Ré, Réb e Dó natural) e as notas Sol e Sib do pedal. Já a mão esquerda apresenta, de fato, todas as notas pertencentes ao omnibus.

\section{Exemplo 57 - Estudo Op. 25 no 11: comps. 17-19}

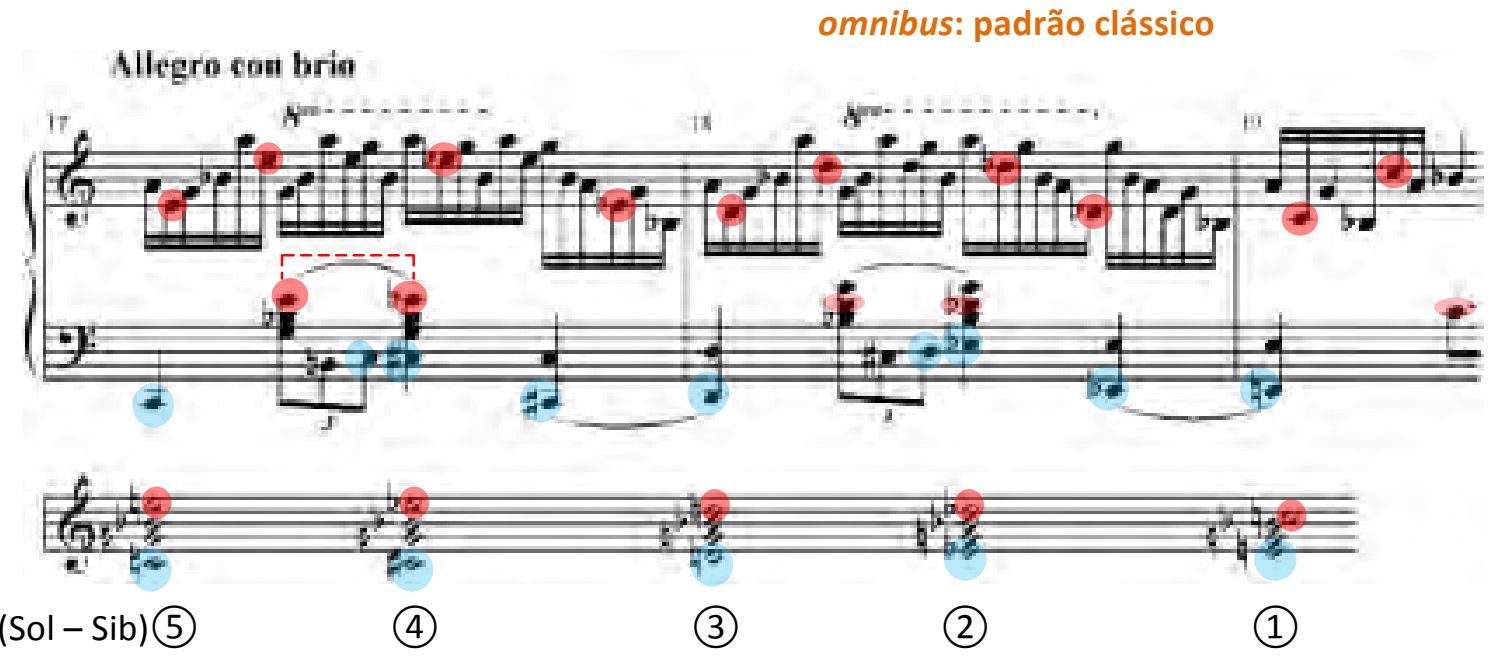

Uma análise deste estudo permite observar a elaborada escrita de Chopin mencionada na introdução deste capítulo, no que diz respeito às variadas organizações das alturas e deslocamentos rítmicos. Neste caso especificamente, a linha cromática ascendente do omnibus torna-se algo mais evidente pelo fato de estar disposta no registro grave. Assim, o que tende a ficar obscurecido é o cromatismo descendente da progressão, por encontrarse distribuído não linearmente tanto na mão direita quanto na mão esquerda. 
De forma mais aprofundada ainda, outro ponto que chama atenção na sua maneira de tecer o discurso musical pode ser visto na manutenção da nota Lá na mão direita desta passagem. Embora possa não ser evidente decifrar num primeiro momento, trata-se de uma nota estranha em relação ao omnibus, ou seja, o Lá é uma apojatura da nota Sol, que constitui parte do pedal da progressão clássica. Assim, uma análise da macro-estrutura deste trecho permite considerar o Sol como a altura principal da linha, numa espécie de voz estática que cria uma camada independente na região mais aguda do estudo.

Assim, é possível criar uma correspondência entre esta característica da melodia encontrada no Op. 25 no $11 \mathrm{com}$ as reflexões feitas por Corrêa sobre a música de Chopin. A partir de uma análise do Prelúdio Op. 28 no 4, o autor ressalta a genialidade do mestre polonês e destaca o modo como é feita a construção da melodia:

[...] ela é excepcional por ter um caráter único, pois se move minimamente entre os pontos e só mais adiante atinge o que é uma melodia: a movimentação livre das alturas pelo campo da tessitura (OLIVEIRA, 2005, p. 12).

Talvez seja este aspecto da escrita de Chopin, seu modo particular de organizar as alturas, ao qual Corrêa se refere em suas reflexões expostas durante seu curso de composição.

De forma análoga ao Estudo Op. 25 no 11, no Prelúdio Op. 28 no 8 (comps. 22 - 23) o Teufelsmühle também tende a passar despercebido, por conta do andamento molto agitato e sttretto e das notas cromáticas distribuídas de forma não linear na mão esquerda. Sobre o baixo cromático descendente Ré\#, Ré e Dó\#, os três acordes destacados no exemplo a seguir compõem a versão A na seguinte disposição: acorde diminuto, germânica e acorde menor com quarta e sexta (Ex. 58).

Exemplo 58 - Prelúdio Op. 28 no 8: comps. 19- 24

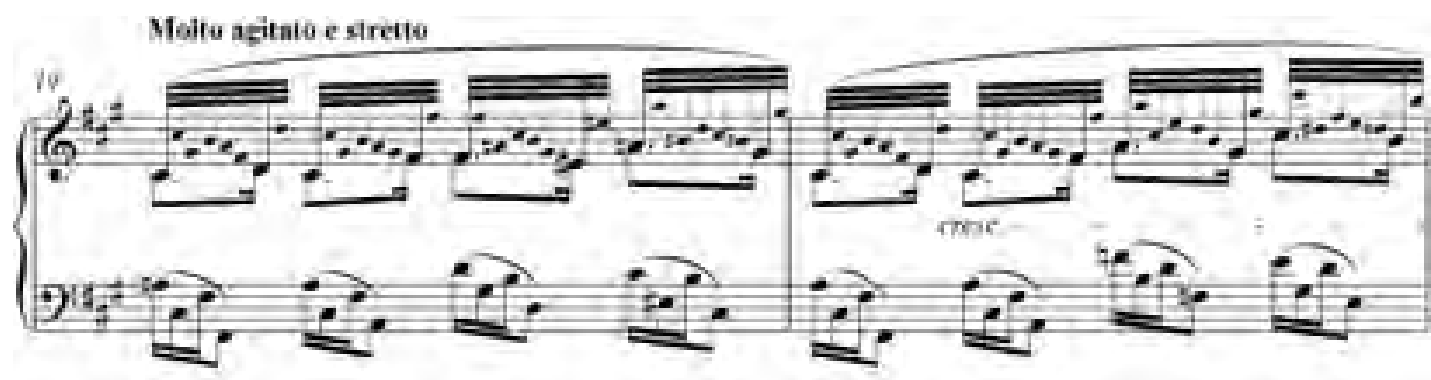




\section{Teufelsmühle}
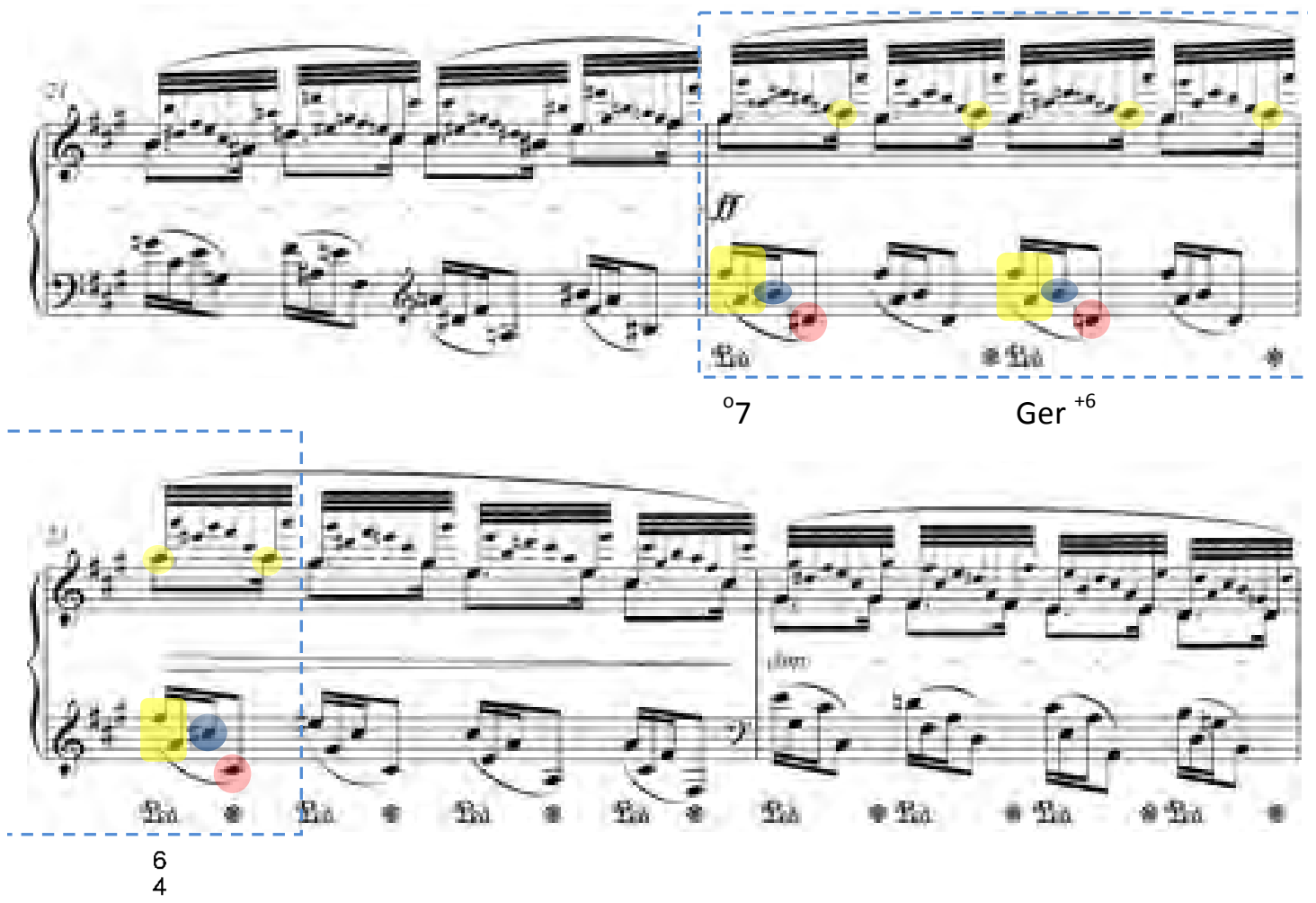

Redução textural: Teufelsmühle versão A
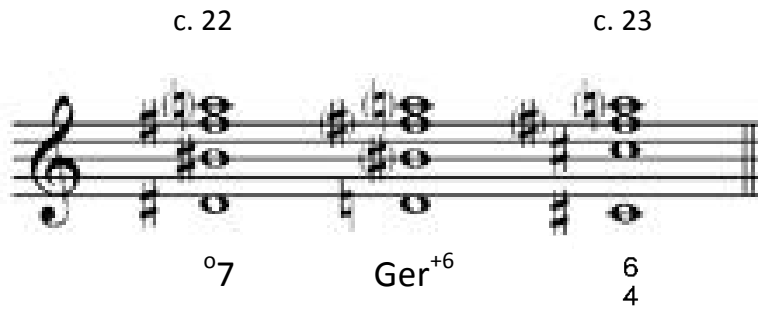

A partir da observação dos compassos 22 e 23 deste prelúdio é possível constatar que as linhas cromáticas do Teufelsmühle encontram-se deslocadas ritmicamente na mão esquerda, como indicadas no exemplo 58 em azul e vermelho, enquanto as notas Lá e Fá\# do pedal, assinaladas em amarelo, estão distribuídas nas duas mãos. Mais uma vez é empregado o recurso de colocar uma das notas do pedal como ponto principal da linha da mão direita (comp. 22). Ou seja, no momento de maior intensidade da peça, em que é alcançada uma dinâmica ff, a melodia fica estática estruturalmente enquanto o ritmo harmônico é dado pela outra mão. Contudo, o compositor elabora esta voz aguda de modo a ornamentar a nota Lá do padrão do Teufelsmühle por uma apojatura, a nota Sol nos tempos fortes do compasso 22. Além disso, como característico de seu estilo composicional, Chopin 
enfatiza a dissonância, neste caso a nota Sol, ao atribuir a ela um valor rítmico maior que a consonância ${ }^{8}$.

Exemplos de Teufelsmühle e omnibus em passagens rápidas encontram-se também no Estudo Op. 10 no 7 (Vivace - comp. 6), Improviso Op. 51 no 3 (Vivace - comp. 75), e Segunda Balada (Presto com fuoco - agitato - comps. 187 -188), entre outros.

\section{2 - FRAGMENTOS}

Neste capítulo o termo fragmentos implica, sobretudo, em uma exposição vinculada às reminiscências das sonoridades do Teufelsmühle/omnibus dentro de uma peça ou em diferentes movimentos de uma obra. Esta memória pode conservar, por vezes, diversos parâmetros, tais como registro, tipologias de acordes, motivo, figuração, estrutura do diminuto gerador, etc. Assim, partindo deste pressuposto, os termos prenúncio e citação serão empregados para se referir às sequências cromáticas.

A idéia de prenúncio diz respeito a um fragmento do Teufelsmühle ou do omnibus, em uma espécie de "embrião" que irá se desenvolver e integrar posteriormente em uma passagem mais ampla e completa destas estruturas.

Ao comparar trechos cromáticos similares previamente selecionados, pode-se reconhecer e reinterpretar uma primeira aparição como um prenúncio do Teufelsmühle ou do omnibus. É importante salientar que a classificação de uma passagem como um prenúncio prevê um estudo mais detalhado da peça, além disso, torna-se fundamental uma argumentação analítica convincente, que permita explicitar e justificar as relações entre tais passagens. Caso contrário, qualquer cromatismo encontrado corre o risco de ser interpretado como um fragmento destas estruturas.

No exemplo a seguir, extraído do Rondo Op. 73, a passagem dos compassos $18-22$ configura-se como um prenúncio do omnibus, como pode ser observado a partir de uma comparação com o trecho dos compassos 55 - 56, no qual o modelo cromático se apresenta na íntegra. Os acordes (5) e (4) do prenúncio são reapresentados na passagem dos

\footnotetext{
${ }^{8}$ Para uma discussão mais aprofundada sobre este aspecto da música de Chopin, cf. artigo "Melodic structuring of harmonic dissonance: a method for analysing Chopin's contribution to the development of harmony" (NARMOUR, 1991, p. $77-114$ ).
} 
compassos 55 - 56 e prosseguem a série até o acorde (1), constituindo a forma retrógrada do omnibus com variante, que assume a função de expansão da dominante principal ${ }^{9}$.

\section{Exemplo 59-Rondo Op. 73: prenúncio e padrão clássico}

a) Comps. $13-24$
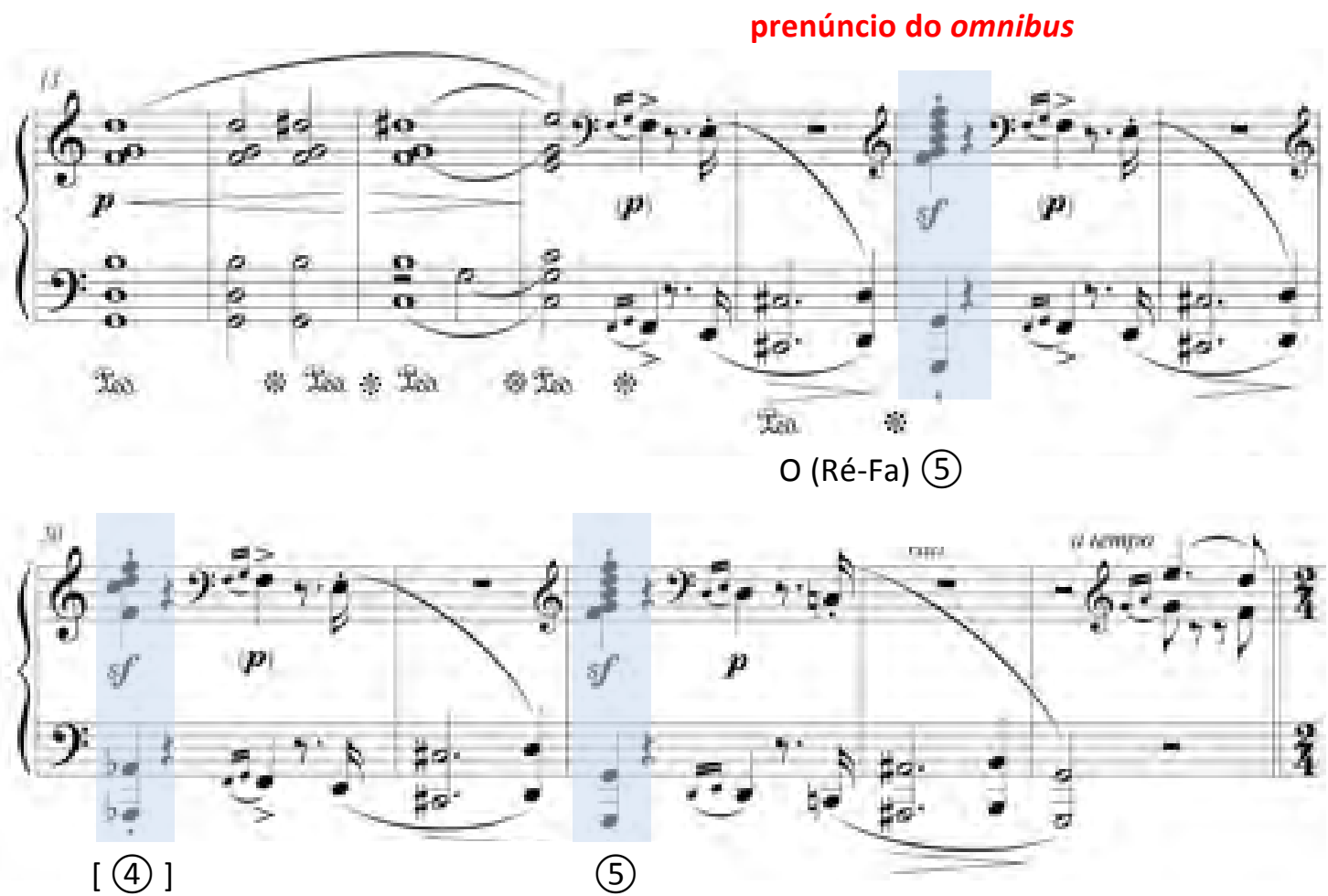

b) Comps. 54 - 58

omnibus com variante

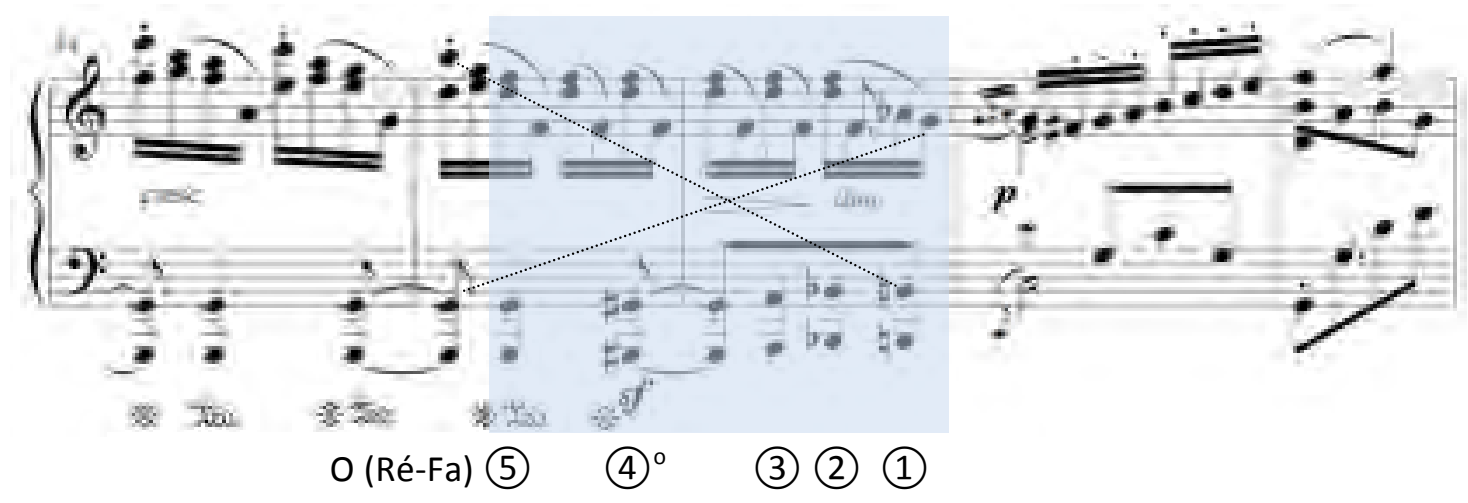

${ }^{9}$ É possível uma interpretação desta passagem como Teufelsmühle versão $A B$, contudo, a escolha da classificação como omnibus se justifica pela ênfase dispensada à condução de vozes, que se aproxima do padrão clássico de Yellin, assim como pela disposição das tipologias de forma consecutiva que atende a função de expansão da dominante com troca de vozes. 
O vínculo auditivo entre os dois trechos destacados no exemplo 59 se apóia na manutenção do diminuto gerador $\left(\mathrm{Si}^{\circ}\right)$, da condução de vozes e de notas no mesmo registro ${ }^{10}$.

Em relação ao padrão clássico do omnibus, as alterações no acorde (4), tanto no prenúncio quanto na passagem do compasso 55 , o transformam em um meio diminuto e diminuto, respectivamente. Já no que diz respeito à condução de vozes, vale destacar que mais uma vez as notas do pedal são colocadas na parte aguda da mão direita (Ré e Fá) nos dois trechos expostos. Quanto ao exemplo 59b, o cromatismo ascendente se faz explícito no baixo enquanto o descendente possui a nota inicial Si no compasso 55 na voz aguda, de forma que ocorre uma interrupção desta linha, retomada no final do compasso 56 com as notas Láb e Sol. Ainda sobre o exemplo 59a, cabe salientar que os acordes (5) e (4) do prenúncio são destacados pelo compositor com as indicações de staccato e $s f$.

Neste momento é possível retomar outra passagem deste rondo, exposta no primeiro capítulo, para verificar a maneira diversificada com que Chopin faz uso dos modelos cromáticos dentro de uma peça. Diferentemente do exemplo 59b, em que não ocorre modulação, nos compassos 205 - 218 (Cf. Ex 16), o compositor emprega a versão A para promover uma modulação entre Dó maior e Mib maior.

Outro tipo de ocorrência comum em Chopin, classificada aqui como citação, configura-se como um fragmento que assume o papel de uma memória ou apenas resquícios dos modelos do Teufelsmühle e omnibus. Exemplos disso podem ser encontrados tanto no transcorrer de uma peça quanto em diferentes movimentos de uma mesma obra.

As passagens a seguir, extraídas do Noturno Op. 55 no 2, ilustram respectivamente a primeira aparição do padrão do omnibus (Fá-Lab): (5) (4) (3) (2) nos compassos 17 - 18 e suas duas citações feitas ao longo da peça. Em associação à exposição inicial, tanto a primeira citação quanto a segunda mantêm: o diminuto gerador (Si diminuto); duas tipologias de acordes [O (Fá-Láb): (5) e (4))] registro; condução de vozes; e figuração em arpejos da mão esquerda.

\footnotetext{
10 Os modelos cromáticos ocorrem em diferentes momentos desta obra, de modo que estes aspectos musicais descritos são usualmente mantidos, o que também reforça a idéia de prenúncio na passagem dos compassos $18-22$.
} 
Exemplo 60 - Noturno Op. 55 no 2: omnibus e suas duas citações

a) Comps. $16-18$

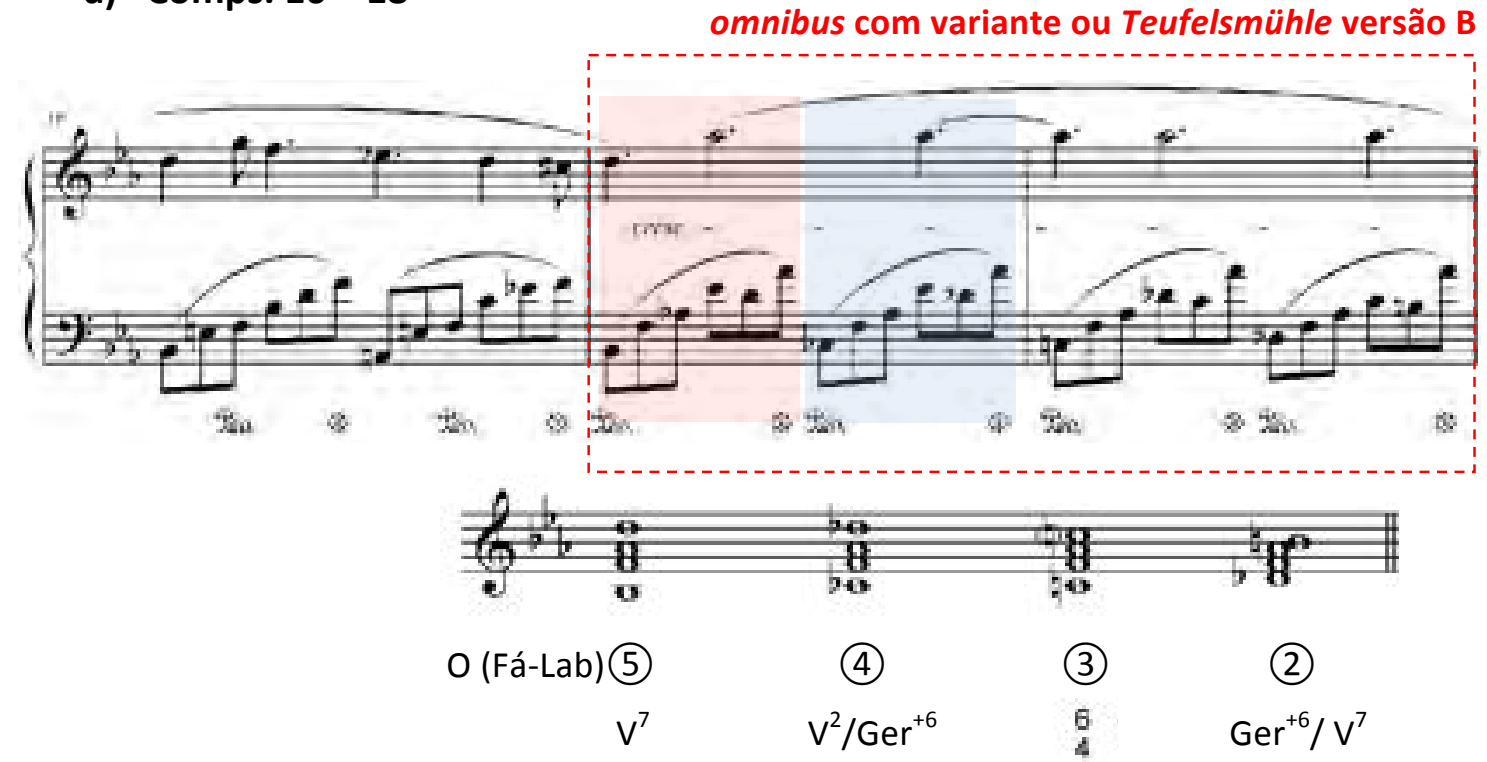

b) Comps. $43-45$

primeira citação do omnibus

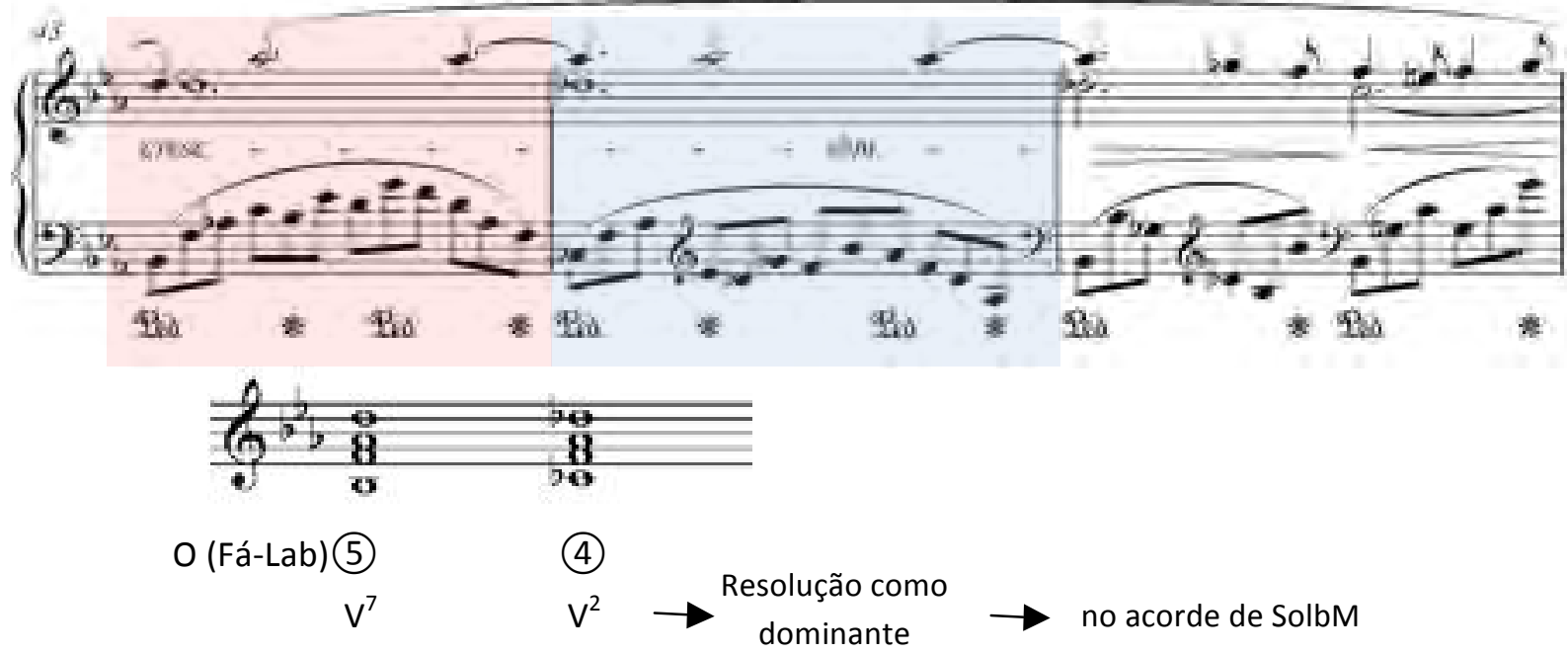

c) Comps. 50 - 52 segunda citação do omnibus

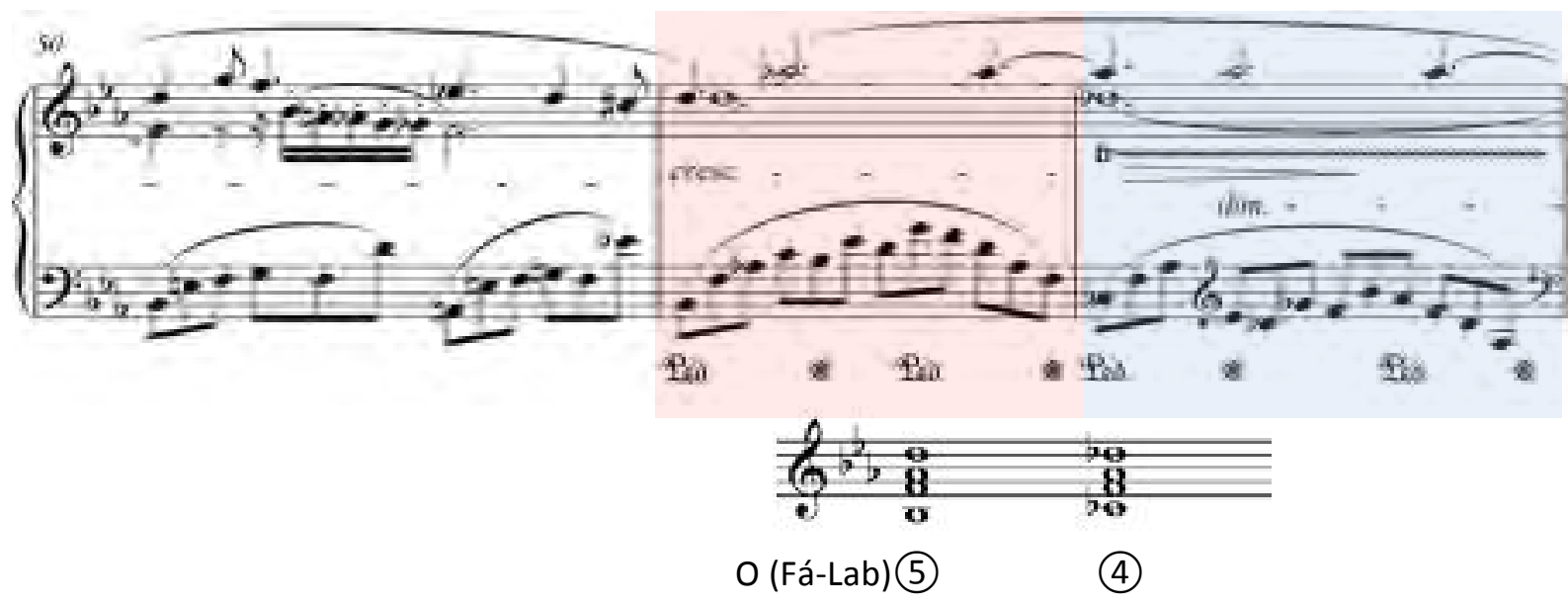


Uma observação deste noturno permite identificar a maneira particular com que é feita a condução de vozes dos modelos cromáticos. Na passagem dos compassos $17-18$, a linha cromática descendente do omnibus, deslocada ritmicamente na mão esquerda (Cf. Ex. 50), é grafada nas duas citações como uma voz independente na mão direita (notas Ré semibreve e Réb semibreve). Novamente a nota pedal, Láb nas três situações, é mantida na linha da mão direita, de forma similar aos exemplos comentados no item anterior.

É curioso notar a precisa indicação de dinâmica feita por Chopin, que coloca um crescendo durante os compassos 17 e 18 e um piano no compasso 19, exatamente no momento em que a progressão é interrompida (Cf. Ex 50). De forma análoga a esta passagem, são indicadas inflexões de dinâmica exatamente nos compassos correspondentes às tipologias (5) e (4) das citações, o que permite imaginar o domínio que o compositor tinha deste procedimento, assim como o efeito musical pretendido nestes momentos.

Um exemplo em que os modelos do Teufelsmühle são sugeridos em diferentes movimentos de uma obra ocorre no Segundo Concerto Op. 21 para piano e orquestra (Ex. 61). A versão $A$ é encontrada duas vezes durante o primeiro movimento, sem variantes e na mesma condução de vozes (comps. 251 - 252 e 295 - 297). O resgate desta sonoridade em forma de citação é feito no segundo movimento (comps. 2 - 3) e no terceiro movimento (comps. 30 - 32).

\section{Exemplo 61 - Segundo Concerto para piano e orquestra Op. 21: Teufelsmühle e citações}

a) 19 mov.: comps. $249-252$

\section{Teufelsmühle versão A}

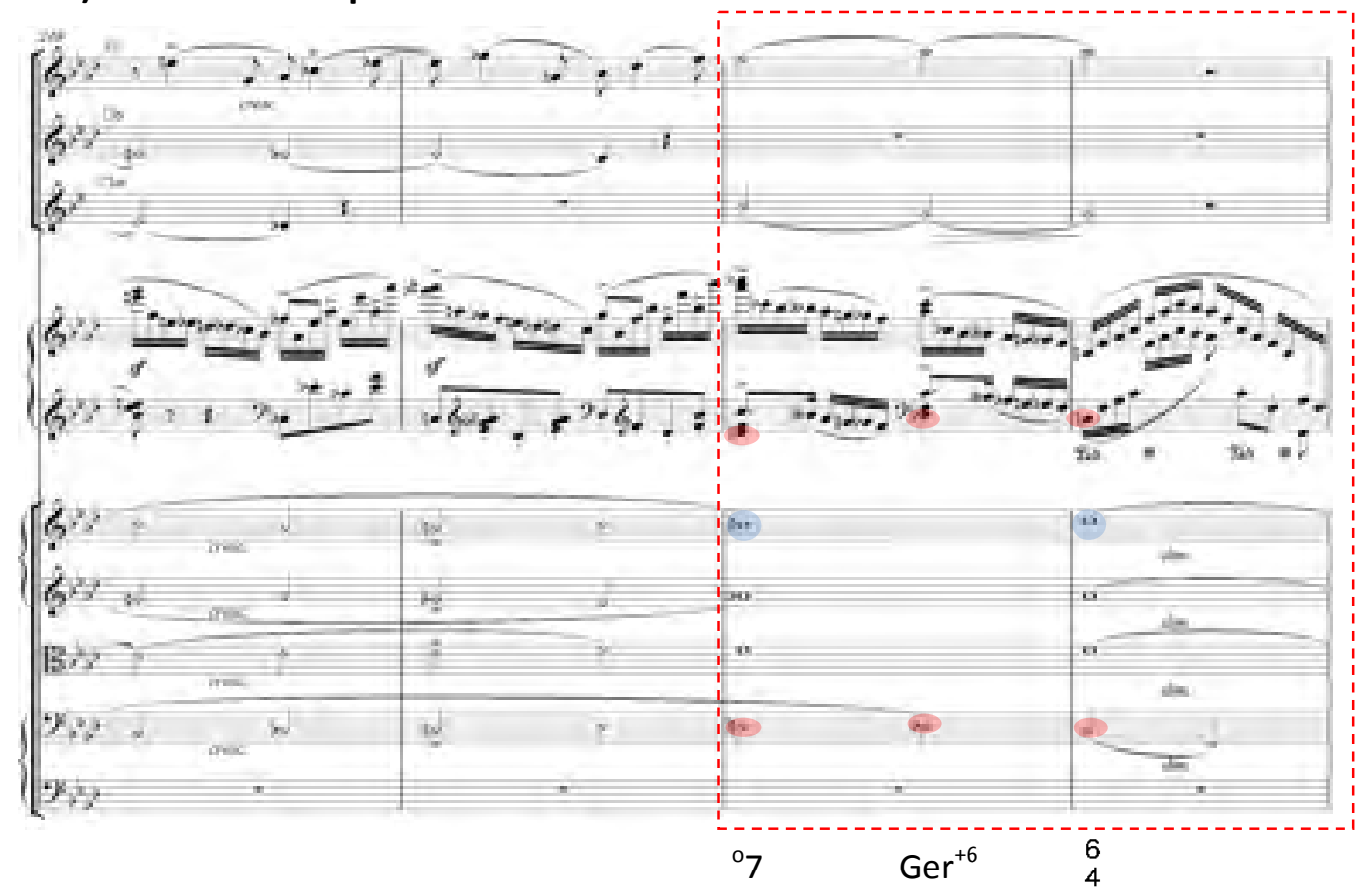


b) 2o mov.: comps. $1-5$

citação do Teufelsmühle versão A, com variante

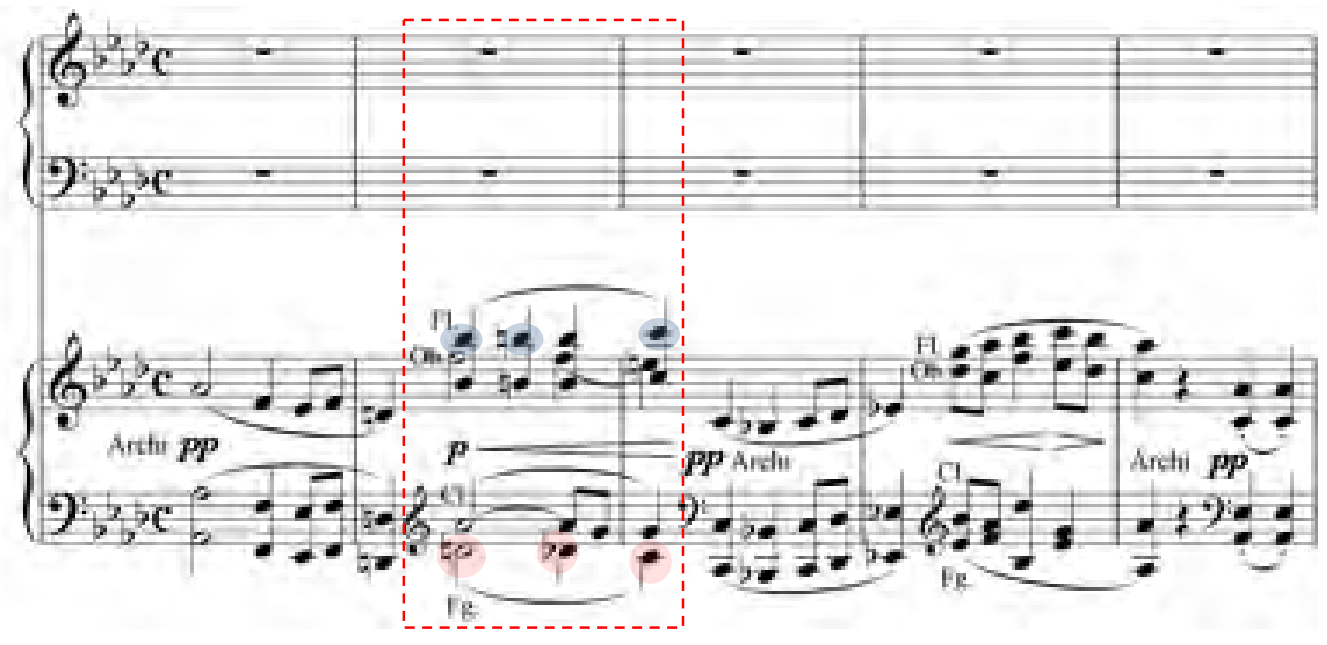

${ }^{0} 7 \mathrm{Ger}^{+6} \mathrm{~V}$

c) 3o mov.: comps. $30-35$

citação do Teufelsmühle versão A, com variante

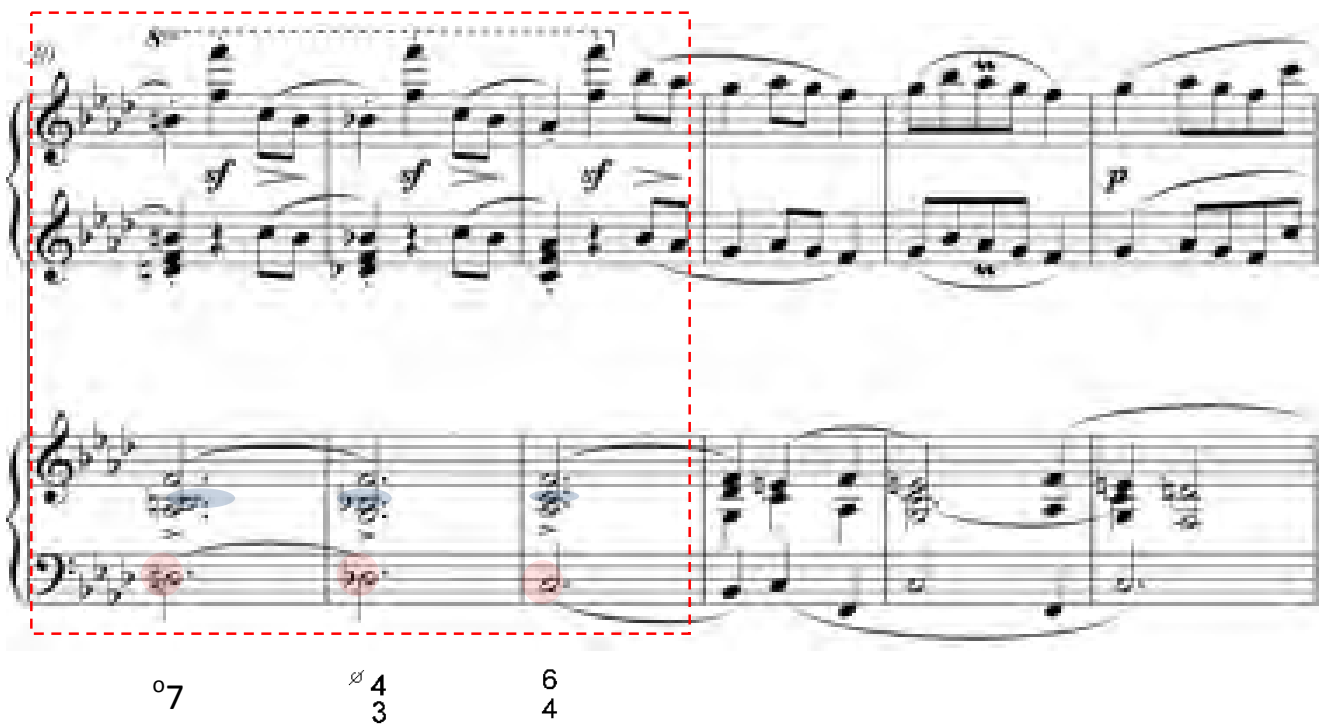

Reduções:

$\begin{array}{ll}\text { a) Mov. I - versão A } & \text { b) Mov. II - citação }\end{array}$

c. 251

c. 252

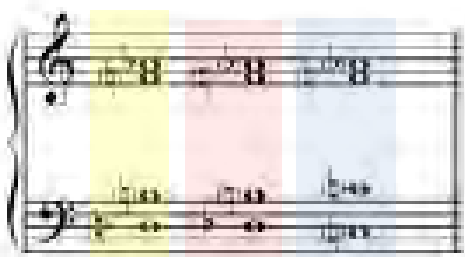

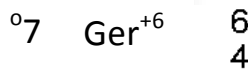

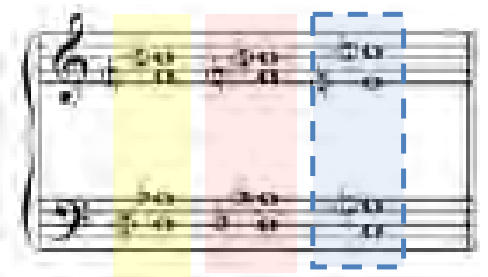

${ }^{0} 7 \mathrm{Ger}^{+6} \mathrm{~V}$ c) Mov. III - citação

$\begin{array}{lll}\text { c. } 30 & \text { c. } 31 & \text { c. } 32\end{array}$

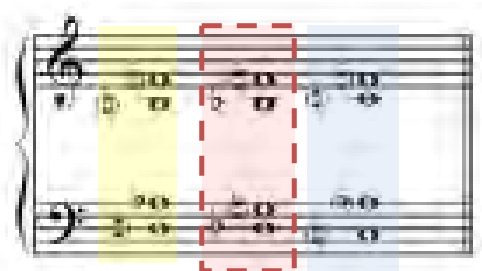

${ }^{\circ} 7 \quad{ }^{\circ} 4$ 
As três passagens expostas no exemplo 61 possuem similaridades, que incorporam desde a mesma seqüência de acordes, o mesmo diminuto gerador $\left(\mathrm{Si}^{\circ}\right)$, até o mesmo baixo cromático descendente (Ré, Réb, Dó). Embora ocorra a manutenção das funções harmônicas entre os acordes correspondentes em cada trecho, destacada com a mesma cor, variantes podem ser observadas na primeira e na segunda citação, se comparado ao modelo do primeiro movimento (comps. 251 - 252). Estes tipos de alterações no segundo e terceiro movimentos, indicados com linhas tracejadas, serão explicados adiante, no tópico específico sobre variantes e em análises de exemplos musicais.

Digna de nota é a condução de vozes no trecho mencionado do primeiro movimento deste concerto, em que as notas do pedal (Fá e Láb) são mantidas com longas durações e distribuídas entre os instrumentos de sopros agudos, flauta e clarinete. De forma análoga a exemplos já expostos neste capítulo, a parte do piano do terceiro movimento desta obra (comps. 30 - 32) também apresenta uma nota do pedal mantida na voz aguda, desta vez com indicações de sf e staccatto.

\section{3 - VARIANTES}

A maneira "Chopiniana" de se apropriar dos modelos codificados por Vogler incorpora alterações que, de forma geral, preservam a essência da sonoridade do Teufes/mühle ou do omnibus e ao mesmo tempo se tornam muito elaboradas.

Os três itens a seguir ilustram algumas das principais variantes e sonoridades encontradas em sua música: substituições dos acordes menores com quarta e sexta; omissões de acordes; e a "variante de Chopin". É importante ressaltar que este último tópico diz respeito a uma classificação exposta e nomeada por esta pesquisa, uma vez que possui uma associação com os modelos do Teufelsmühle e omnibus.

\section{3. 1 - Substituição do acorde menor com quarta e sexta}

A substituição do ${ }_{4}^{6}$ por um acorde maior, também com quarta e sexta, é comum na música de Chopin. Um exemplo deste procedimento é encontrado no compasso 60 da 
Polonaise Op. 26 no 1, que emprega quatro acordes da versão A do Teufelsmühle no exemplo $62^{11}$.

Exemplo 62 - Polonaise Op. 26 no 1: comps. 59-61

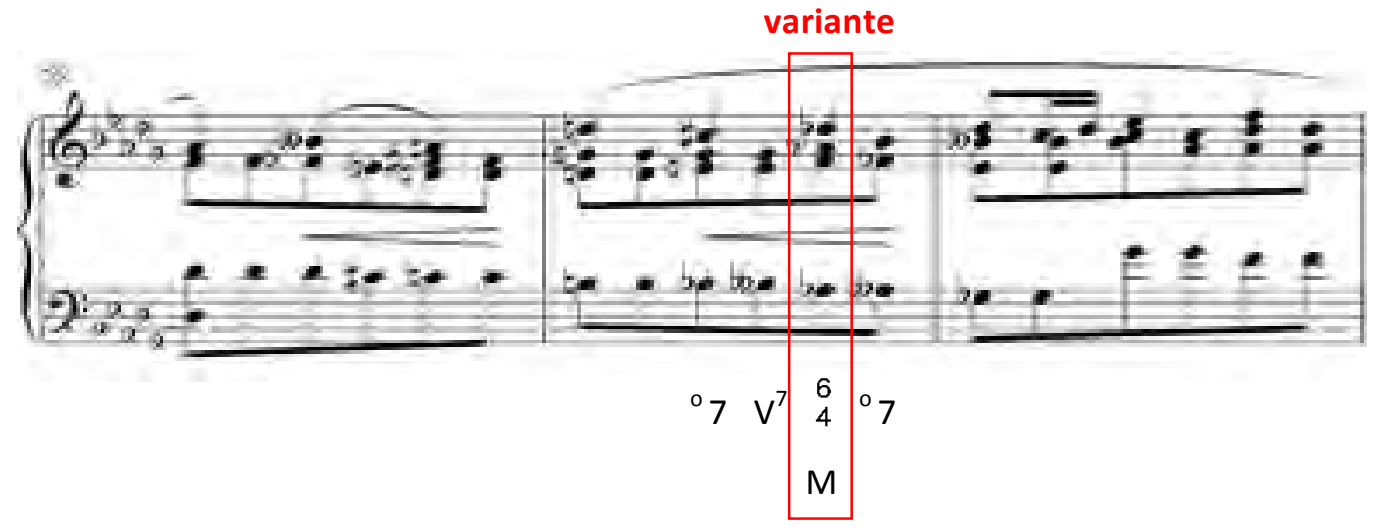

Redução:

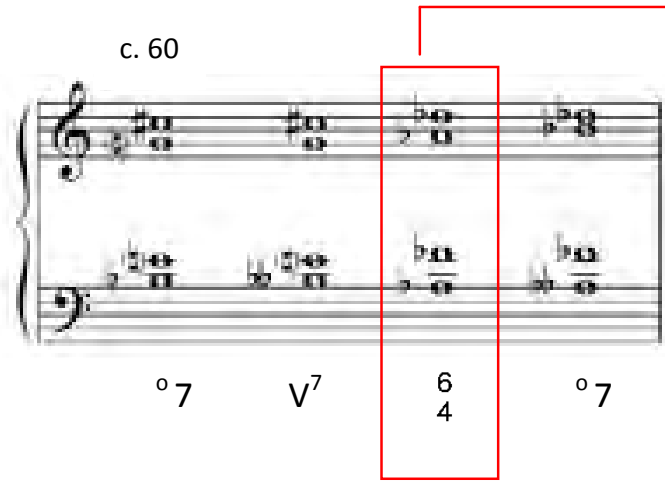

Teufelsmühle versão A

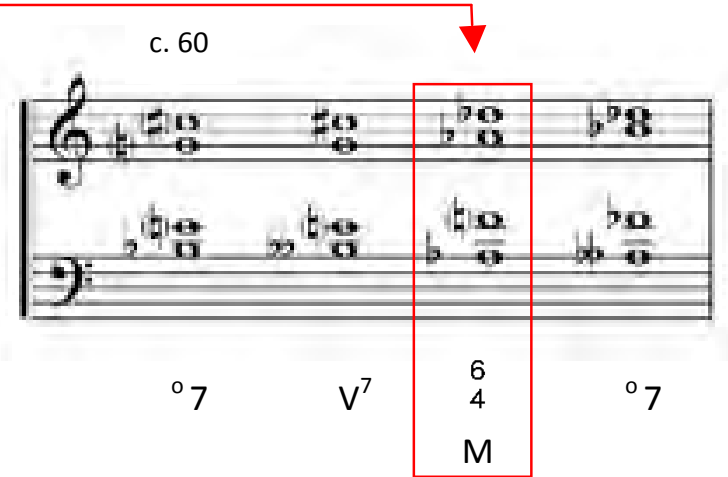

Polonaise Op. 26 no 1: Teufelsmühle versão A com variante

Nesta polonaise as notas mantidas em relação de terça menor são Dó\# e Mi, que sofrem uma mudança de grafia para Réb e Fáb, respectivamente. Novamente uma nota do pedal está disposta na parte mais aguda da mão direita, neste caso Dó\#/Réb.

Outro tipo de variante localizado com freqüência em sua música chama atenção: trata-se da substituição do acorde menor com quarta e sexta por uma dominante, isto é, um acorde maior em estado fundamental, com ou sem sétima.

Um claro exemplo que fundamenta e contextualiza este ponto ocorre no Noturno Op. 55 no 1 (comps. 69 - 71), em que a versão B do Teufelsmühle é empregada a partir de um baixo cromático descendente (Réb, Do natural, Dob, Sib) e com as seguintes tipologias:

11 Outros exemplos também ocorrem na Primeira Balada Op. 23 (comps. 153 - 158); Noturno Op. 48 no 2 (comps. 121 -122); e Rondo Op. 1 (comps. 192 - 195). 
dominante com sétima/sexta aumentada; acorde maior em estado fundamental no lugar do acorde menor com quarta e sexta; dominante com sétima no baixo; e dominante em estado fundamental (Ex. 63).

Exemplo 63 - Noturno Op. 55 no 1: comps. 65 - 75

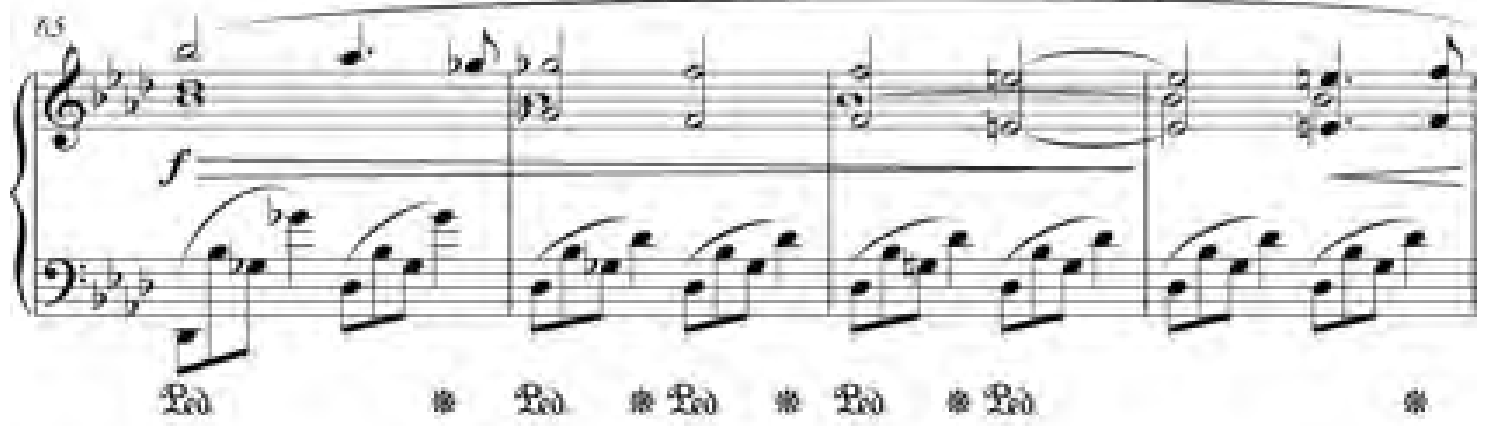

Variante: substituição do acorde menor com quarta e sexta por uma tríade maior em estado fundamental.
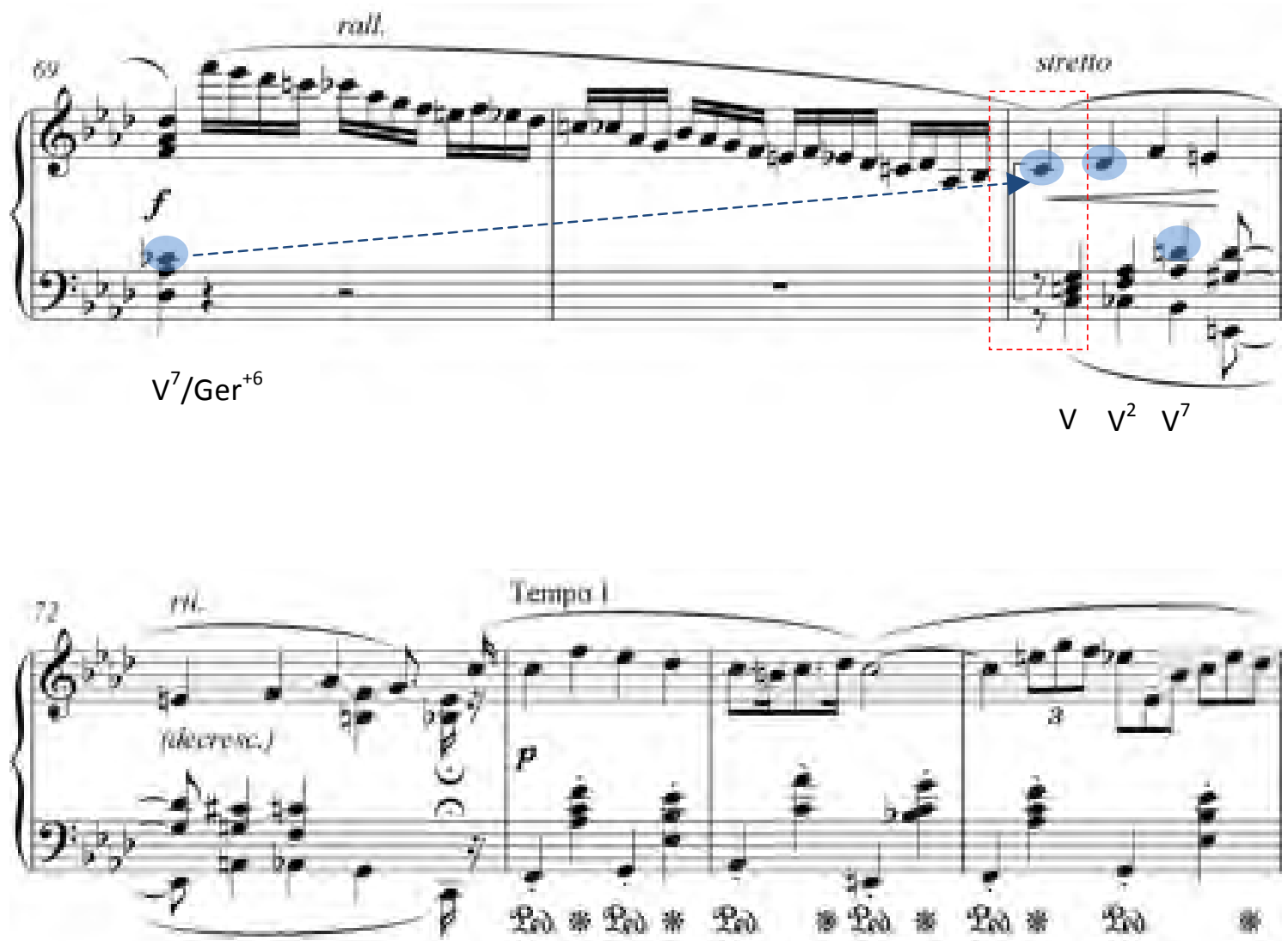


\section{Redução:}

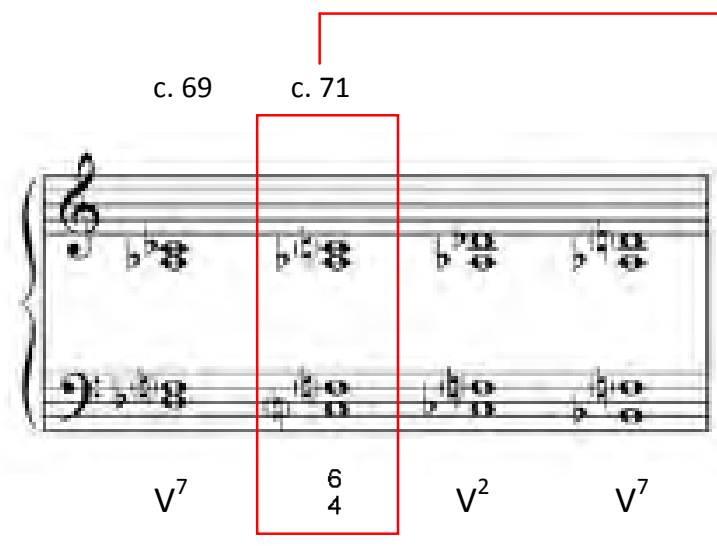

Teufelsmühle versão B

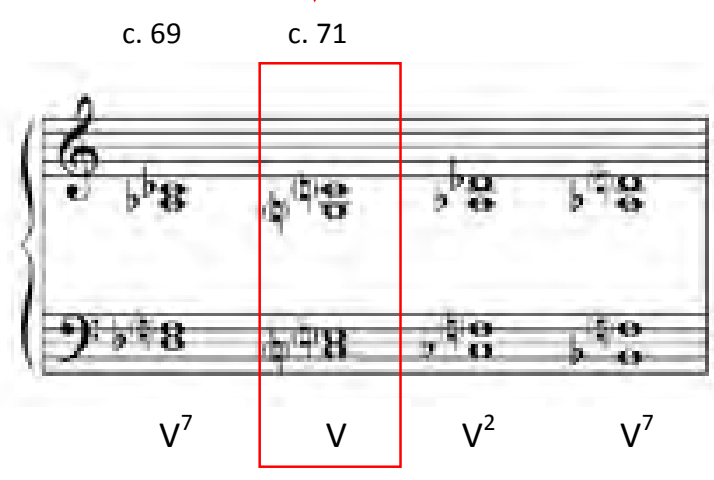

Noturno Op. 55 no 1: Teufelsmühle versão B com variante

Uma comparação entre estas duas reduções permite observar a troca do acorde menor com quarta e sexta da versão B pelo acorde maior sem sétima, presente no compasso 71 do Noturno $O p .55$ no 1. Vale salientar que esta alteração resguarda a mesma nota fundamental e função do acorde original do Teufelsmühle.

Numa outra perspectiva, a análise da redução específica do noturno permite também revelar que a linha condutora do cromatismo ascendente encontra-se com várias intervenções. Num primeiro momento, a nota inicial Dob não se faz aparente, uma vez que está disposta em uma voz interna no primeiro tempo do compasso 69. É importante perceber que este Dób se dirige para a nota Do natural, exposta de forma explícita na linha da mão direita dois compassos à frente (comp. 71). A outra intervenção é a introdução da nota Fá do pedal, na mão direita no compasso 71, no lugar da nota Ré natural, o que torna mais uma vez o cromatismo não evidente.

Ainda sobre este exemplo, é curioso observar que Chopin sinaliza uma inflexão de tempo e dinâmica dentro da passagem do Teufelsmühle, exatamente neste momento em que ocorre a variante. O rallentando a partir do compasso 69 , assim como o sttreto e a chave de dinâmica no compasso 71 valorizam este aspecto estrutural ${ }^{12}$.

\footnotetext{
12 Dentre outros exemplos que integram esta variante: Estudo Op. 10 no 4 (comps. 25 - 27) e o quarto movimento da Sonata Op. 58 no 3 (comps. 183 - 191).
} 


\section{3. 2 - Omissões de acordes}

Esta possibilidade de variante, também comumente encontrada, prevê a omissão de qualquer um dos acordes integrantes de cada grupo do Teufelsmühle ou de qualquer uma das tipologias do omnibus.

No exemplo a seguir, extraído da Valsa Op. 42, ocorre omissão da dominante com sétima (SolM com $7 \mathrm{~m}$ ) da versão $\mathrm{B}$ do Teufelsmühle, assinalada em vermelho e com colchetes no exemplo 64.

Exemplo 64 - Valsa Op. 42: comps. $259-263$

Teufelsmühle versão B

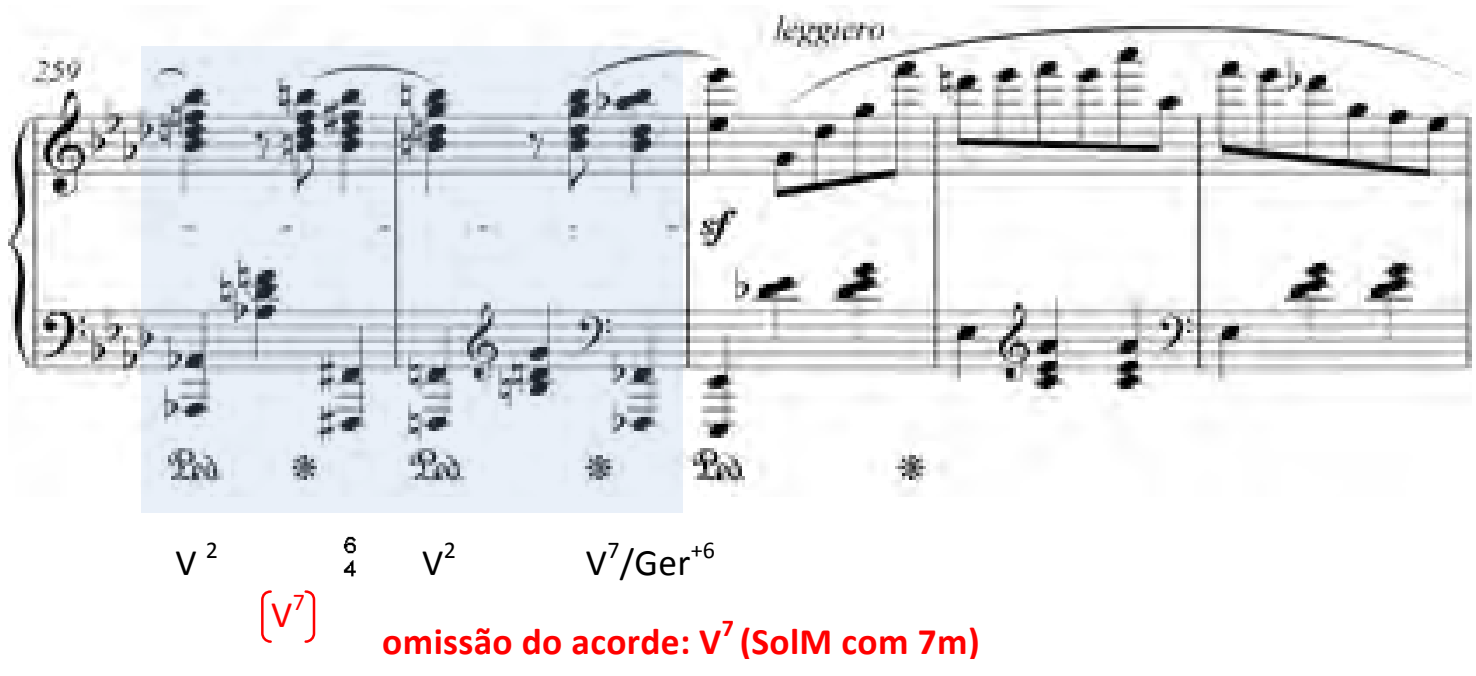

Redução: Teufelsmühle versão B com variante
C. 259
c. 260

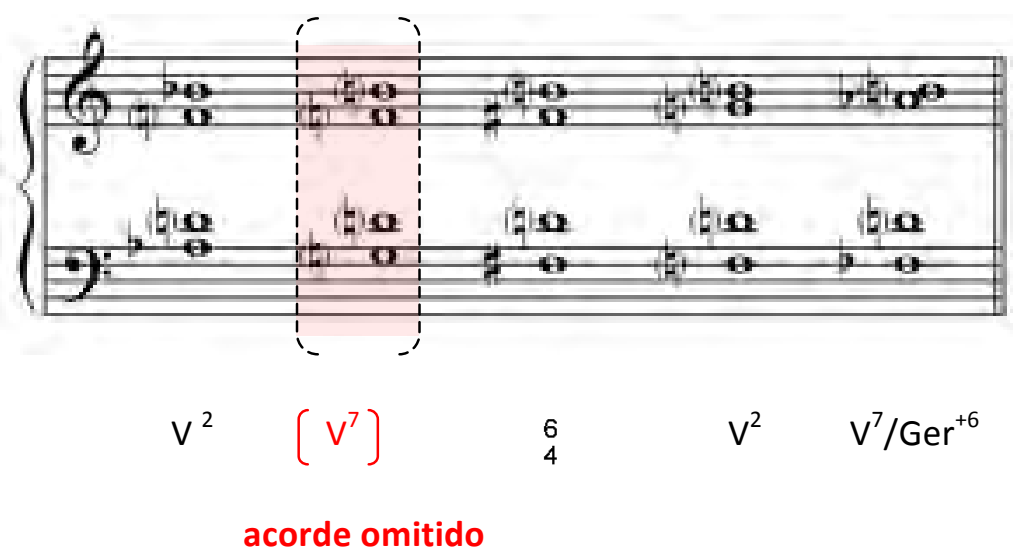


Ainda sobre a passagem da Valsa Op. 42 observa-se a nota Si natural, constituinte do pedal, mantida na parte aguda da mão direita, da mesma forma como ocorreu em exemplos musicais expostos neste capítulo.

Digno de nota é o trecho compreendido entre os compassos 6 a 8 do Prelúdio $O p .28$ no 9, no qual é encontrada uma longa sequência do omnibus e do Teufelsmühle com variantes, em que o baixo deixa de ser totalmente cromático, por conta da omissão de vários acordes (Ex. 65).

\section{Exemplo 65 - Prelúdio Op. 28 no 9: comps. 6 - 9}
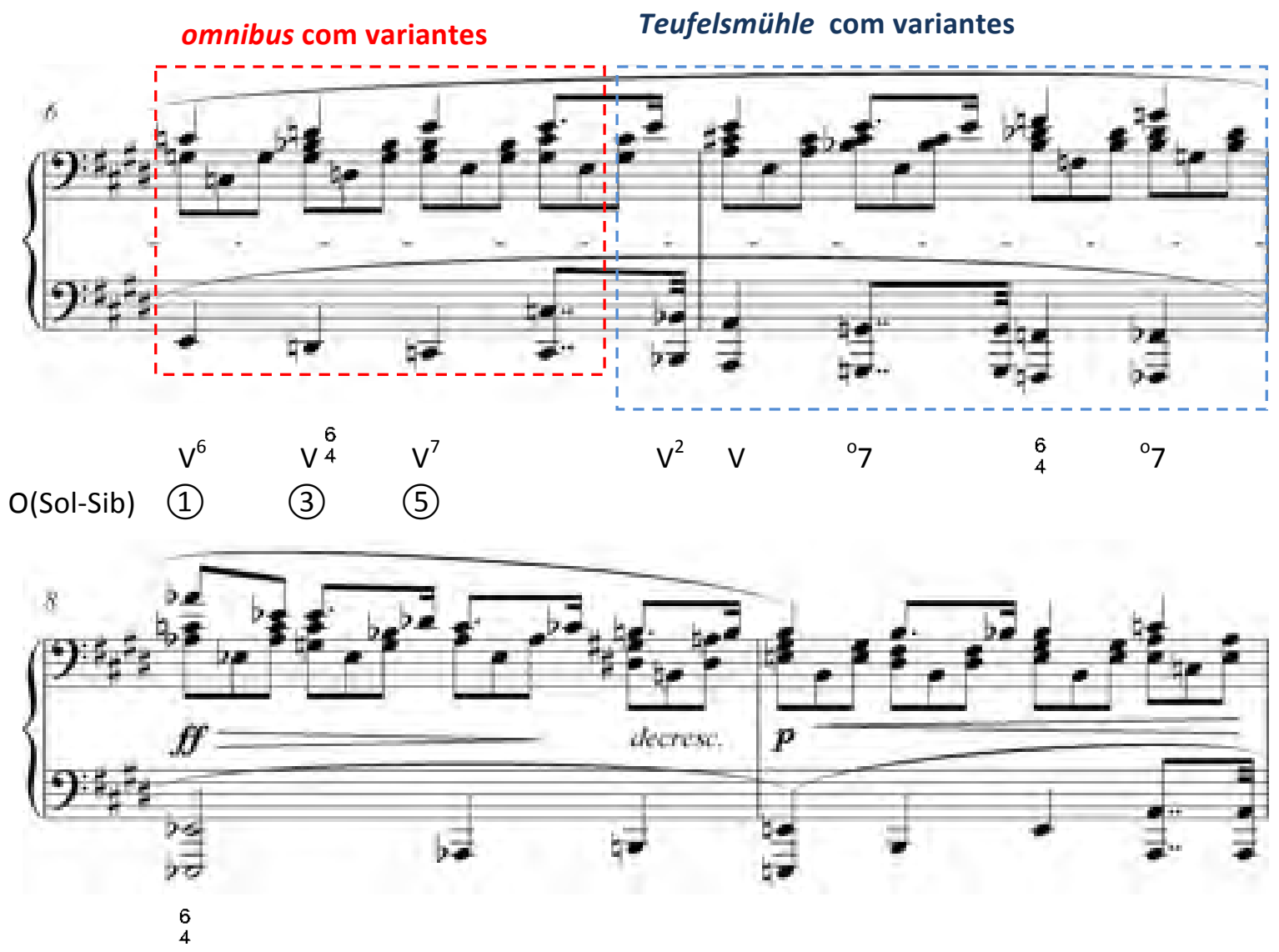

(M)

Neste prelúdio em MiM é empregada uma progressão que pode ser considerada como omnibus com omissão de nota e de acordes (comp. 6), uma vez que falta a nota Sib no (1) e que os acordes (2) e (4) não estão presentes.

Uma observação relevante diz respeito ao fato de que apenas o primeiro acorde (Dó Maior em primeira inversão no tempo forte do compasso 6), mesmo com a omissão da sétima, configura-se como típico do omnibus. Todas as demais tipologias da sequência 
inteira podem ser interpretadas como integrantes do Teufelsmühle. Assim, a escolha de uma visão com omnibus no compasso 6 está também associada à condução de vozes, que neste momento é idêntica ao modelo exposto por Yellin, ou seja, com as notas do pedal mantidas nas vozes internas (Sol - Sib) enquanto que as notas que compõe o cromatismo em movimento contrário e simétrico estão nas linhas extremas. O trecho prossegue com os modelos do Teufelsmühle versões A e B, com a omissão de três acordes, como destacado na redução a seguir. Além disso, para concluir o padrão do Teufelsmühle, o último acorde deste exemplo apresenta ainda outra variante: a substituição do acorde menor com quarta e sexta pelo maior com quarta e sexta (Ex. 66).

\section{Exemplo 66 - Prelúdio Op. 28 no 9: redução}

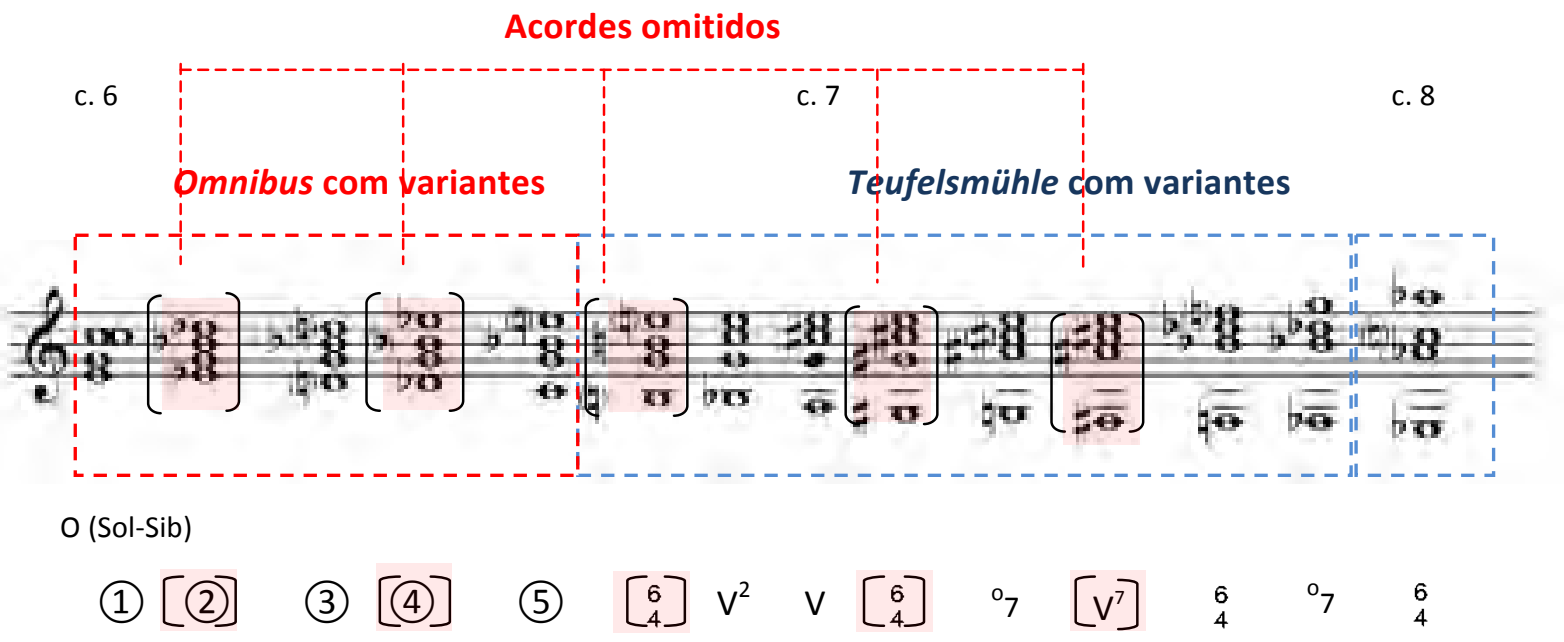

A observação da partitura do trecho em questão revela ainda a indicação de uma dinâmica graduada, o crescendo a partir do compasso 6 para atingir o fortíssimo no compasso 8. Além disso, os modelos cromáticos neste prelúdio configuram-se no momento de maior contraste harmônico da peça ${ }^{13}$.

O emprego desta estrutura na íntegra e de forma transformada, ou seja, com alterações nas tipologias e omissões de acordes, proporciona um uso renovado do omnibus e Teufelsmühle por Chopin.

Ainda dentro deste tópico, vale ressaltar o emprego específico deste artifício com a omissão de todos os acordes menores com quarta e sexta. A peculiaridade que este uso

\footnotetext{
${ }^{13}$ Um exemplo com omissões de acordes, de forma muito similar a este prelúdio, acontece na Terceira Sonata Op. 58, 3 mov (comps. 22 - 23). Nesta passagem da sonata o omnibus é variado de maneira muito próxima ao compasso 6 do Op. $28 n$ o 9, com a sequência (1) (3) (5) na mesma condução de vozes.
} 
oferece é sua relação com a escala octatônica e, conseqüentemente com o segundo modo de transposição limitada de Messiaen ${ }^{14}$.

O Estudo Op. 10 no 8 constitui um exemplo da utilização deste recurso no trecho entre os compassos 36 a 40, em que ocorre a presença do baixo cromático descendente (Dó, Si, Sib e Lá) harmonizado apenas por acordes de sétima diminuta e dominante com sétima (Ex. 67).

Exemplo 67 - Estudo Op. 10 no 8: comps. $35-40$

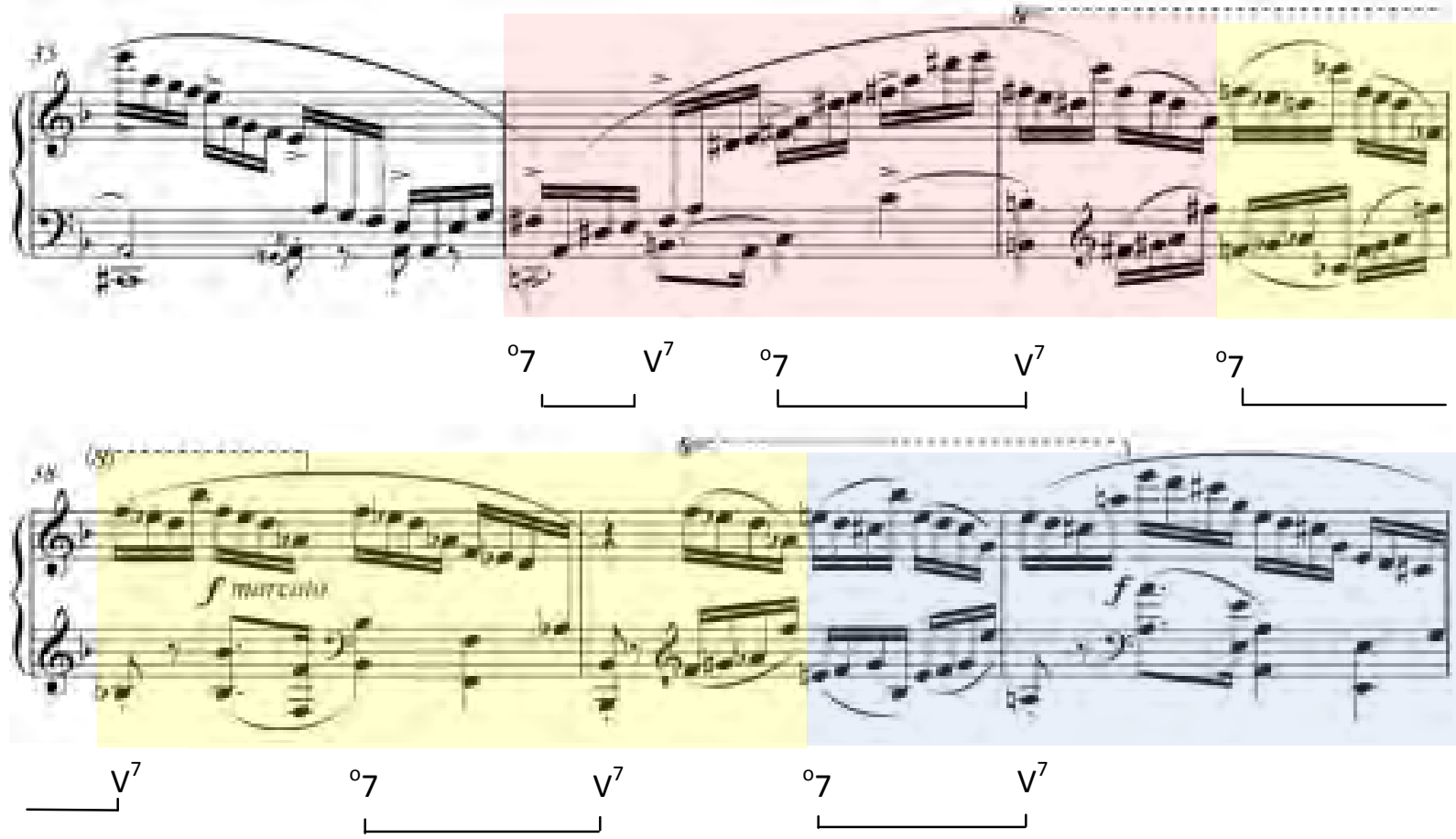

Redução: Teufelsmühle versão A

c. 36

c. 37

c. 38

c. 39

c. 40

Diminutos geradores:

acordes menores com quarta e sexta omitidos

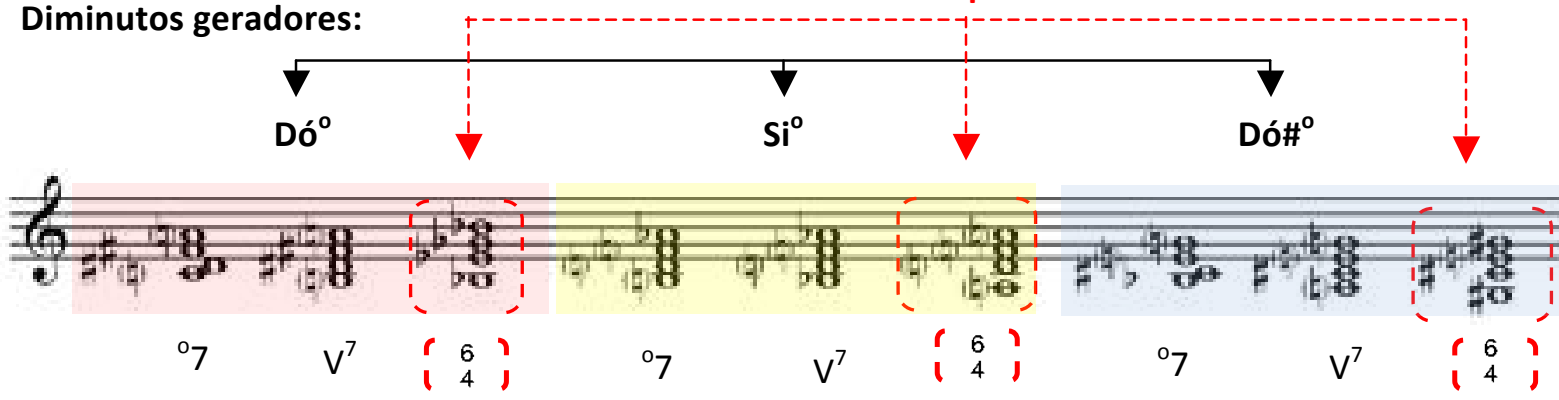

octatônica formada por $\mathrm{Dó}^{\circ} \mathrm{e} \mathrm{Si}^{\circ}$

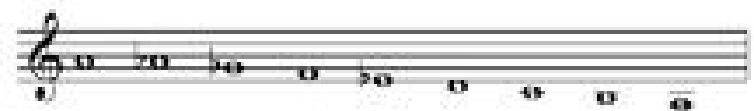

octatônica formada por $\mathrm{Si}^{\circ}$ e Dó\#

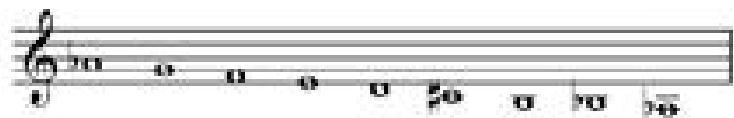

${ }^{14}$ Cf. os exemplos 21, 22 e 23. 
No exemplo 67 os compassos encontram-se assinalados por cores que representam a versão A do Teufelsmühle nas diferentes transposições da estrutura do acorde diminuto. Conforme detalhado na redução da passagem, os acordes omitidos encontram-se assinalados entre parênteses, além disso, a cor vermelha corresponde ao gerador Dó ${ }^{\circ}$ enquanto que o amarelo e o azul estão vinculados ao $\mathrm{Si}^{\circ}$ e Dó\# ${ }^{\circ}$, respectivamente.

Os compassos 36 e 37 empregam quase que exclusivamente as notas da octatônica formada pelos diminutos $\mathrm{Dó}$ e $\mathrm{Si}$, de modo que a nota Mi presente no trecho é a única que não faz parte da coleção resultante da escala, assumindo apenas a função de nota de passagem. Com exceção da nota Mib, o trecho seguinte (comps. 38 - 40) faz uso apenas das notas da octatônica formada por $\mathrm{Si}^{\circ}$ e Dó\# .

Desta forma, o emprego destas diferentes transposições associado às omissões de acordes acarretam em uma intensa complexidade musical. Além disso, o fato das progressões do Teufelsmühle, via de regra, não apresentarem um tipo de condução de vozes definida faz com que a localização neste estudo se torne ainda mais complicada.

\section{3.3 - "Variante de Chopin"}

Trata-se de uma sonoridade que marca a práxis composicional de Chopin e que, de certo modo, está intimamente relacionada às sequências do Teufelsmühle e omnibus. Para tanto, as demonstrações estruturais que serão feitas a seguir serão acompanhadas com exemplos musicais, com o objetivo de ilustrar esta associação proposta de forma contextualizada.

A descrição da variante de Chopin irá abarcar as tipologias dos acordes que a compõe, assim como a condução de vozes gerada, uma vez que são fatores decisivos, que preservam o vínculo auditivo com os modelos cromáticos.

Esta variante constitui um fragmento formado por dois acordes, empregado pelo compositor em uma forma sintética, se comparada às sequências do padrão clássico do omnibus, com cinco acordes, ou do Teufelsmühle, com no mínimo três. O fato da variante de Chopin apresentar somente duas tipologias não diminui sua relevância e tampouco sua abrangência. Assim, esta sonoridade ocorre como uma unidade estrutural singular e possui uma dimensão ampla, como será destacado a seguir.

As diferentes formas de apresentação desta variante incorporam, num primeiro momento, algumas possibilidades de tipologias para o primeiro acorde, tais como maior em estado fundamental, maior com sétima menor; e tríade menor em estado fundamental. A 
variante de Chopin se completa no momento em que cada um destes acordes é seguido por uma dominante com a sétima no baixo (Ex. 68).

\section{Exemplo 68 - Variante de Chopin: padrões e suas tipologias}

\begin{tabular}{|c|c|c|}
\hline 10 acorde & & 20 acorde \\
\hline V & $\rightarrow$ & $v^{2}$ \\
\hline$V^{7}$ & $\rightarrow$ & $\mathrm{V}^{2}$ \\
\hline menor em &.$F$ & $V^{2}$ \\
\hline
\end{tabular}

Neste momento torna-se importante esclarecer que o aspecto fundamental que permite elencar estas três possibilidades descritas no quadro é a condução de vozes, ou seja, o reconhecimento da sonoridade está intimamente relacionado à questão horizontal da composição. Cada uma das versões da variante de Chopin apresenta, no mínimo, duas vozes em movimento contrário, cromático e simétrico. Nos três casos a fundamental do primeiro acorde encontra-se dobrada, de modo que uma delas realiza o cromatismo descendente no baixo enquanto que a outra faz o movimento cromático ascendente ${ }^{15}$ (Ex. 69).

\section{Exemplo 69 - Variante de Chopin: ênfase na condução de vozes}

a)

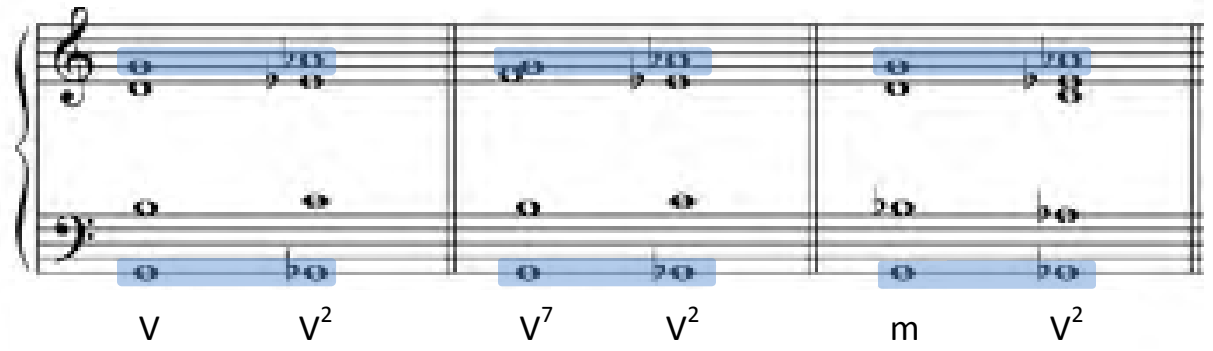

A possibilidade apresentada no exemplo 69a pode ser observada no Noturno Op. 48 no 1, em que o primeiro acorde maior em estado fundamental, é seguido pelo acorde de dominante com sétima no baixo, compassos 71 e 72 (Ex. 70).

\footnotetext{
${ }^{15}$ Cabe salientar que o cromatismo ascendente pode estar disposto em qualquer voz.
} 
Exemplo 70 - Noturno Op. 48 no 1: comps. $71-77$
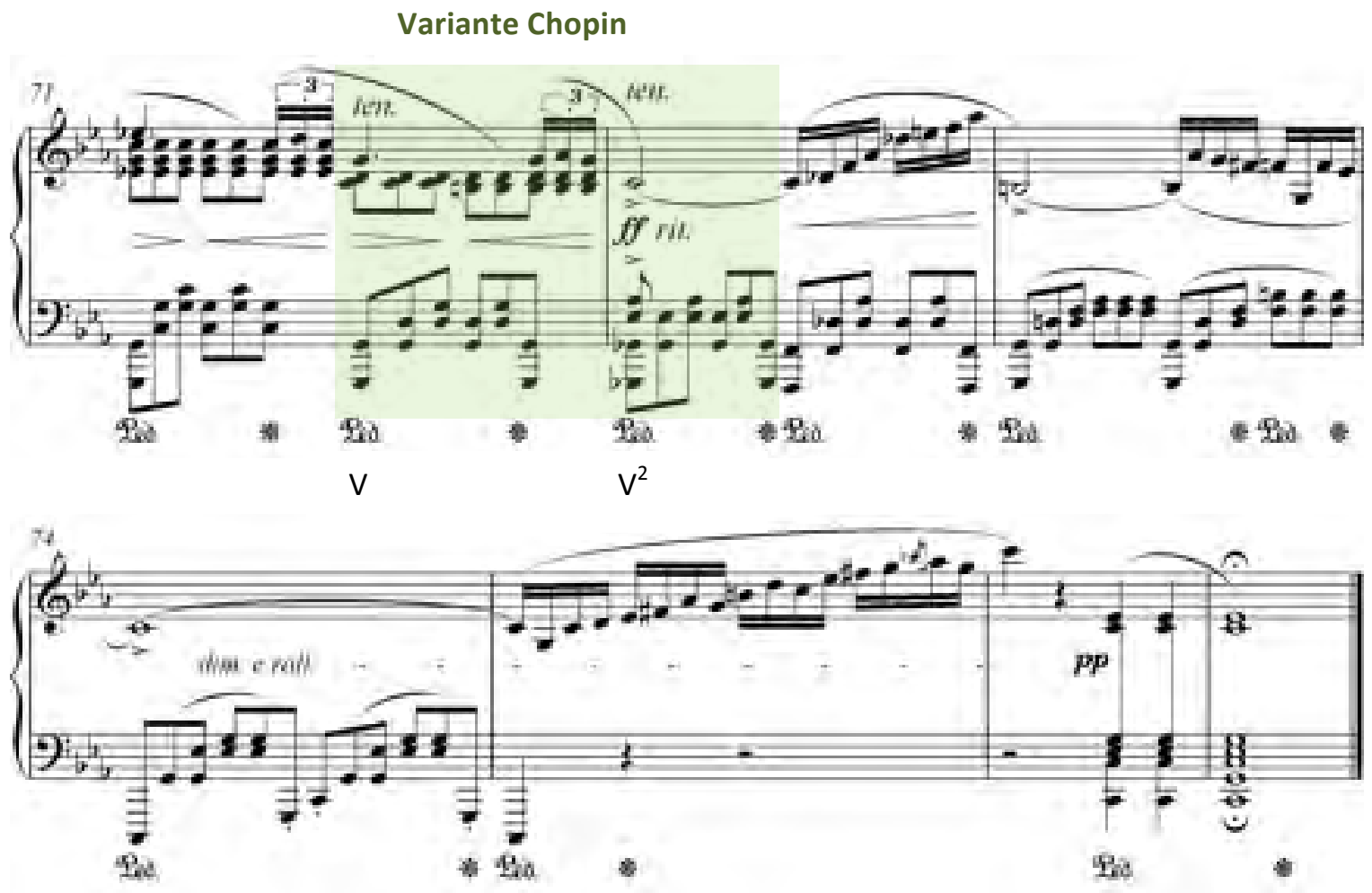

Redução - variante de Chopin

c. 71

C. 72

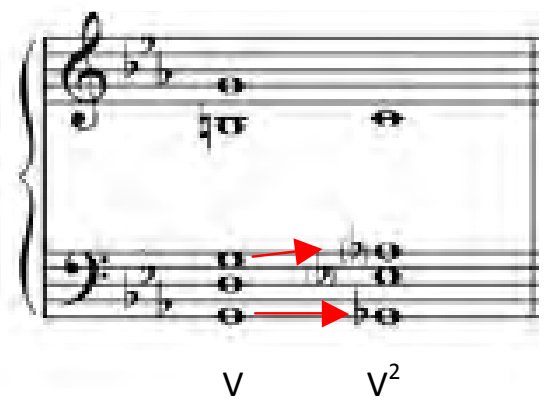

Na redução dos compassos 71 - 72 deste noturno a fundamental Sol da primeira dominante está disposta na linha do baixo, que realiza o cromatismo descendente, enquanto que seu dobramento ocorre numa voz interna que se dirige para Lab (cromatismo ascendente). Por vezes, é comum ainda encontrar outro cromatismo ascendente resultante, que reforça a pontuação na dominante de chegada, que neste caso é representado pelas notas Si natural e Dó natural.

Inserida no momento que inicia a coda, a variante neste noturno anuncia a mudança para uma textura mais rarefeita, se comparada ao trecho precedente, mais denso, devido principalmente ao uso da figuração de acordes em ambas as mão. Além disso, a chegada em 
uma dinâmica ff no compasso 72 , associada ainda as indicações de tenuto, acento e ritenuto evidenciam o contraste musical pretendido pelo compositor ${ }^{16}$.

A próxima apresentação ilustra o uso do acorde maior com sétima menor $\left(\mathrm{V}^{7}\right)$ seguido pela dominante com sétima no baixo $\left(V^{2}\right)$, como pode ser visto entre os compassos 142 - 143 da Fantasia Op. 49 (Ex. 71).

Exemplo 71 - Fantasia Op. 49: comps. 142 - 144

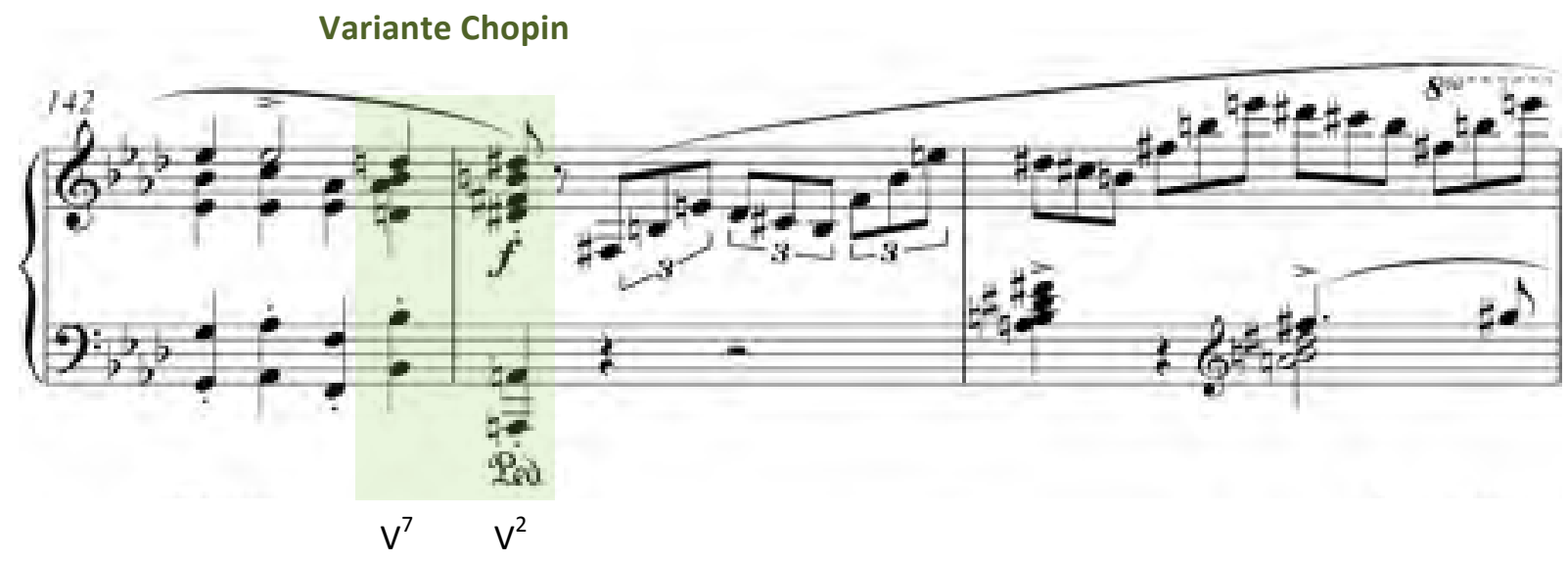

Redução: variante de Chopin
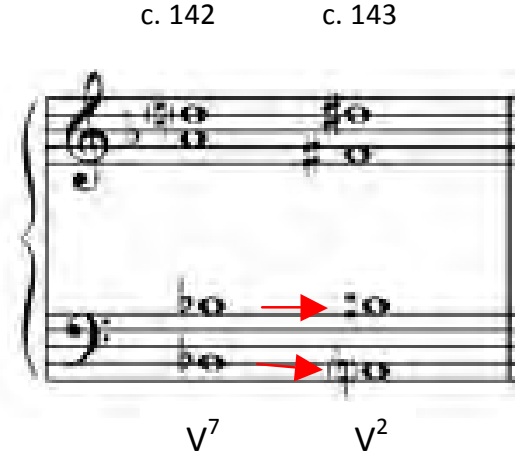

De forma similar à condução apresentada no exemplo anterior, na Fantasia Op. 49 o cromatismo descendente (Sib - Lá) ocorre na linha do baixo ao passo que o ascendente é feito em vozes internas (Sib - Si natural). Neste caso, o outro cromatismo está representado pelas notas Ré natural e Ré\# na linha mais aguda.

Sobre este exemplo, torna-se essencial esclarecer que a variante de Chopin não se trata apenas de dois simples acordes encadeados. Esta estrutura assume uma dimensão

16 Outros exemplos desta variante podem ser encontrados na Segunda Balada (comps. 114 - 115), no quarto movimento da Terceira Sonata (comps. 184 - 187), bem como no Estudo Op. 25 no 4 (comps. 35 - 38). Nesta última peça chama atenção o uso da variante repetida sete vezes consecutivamente, em associação com inflexões de dinâmica que incorporam chaves de crescendo e decrescendo. 
tamanha, fato comprovado na fantasia a partir do compasso 142, pela extensão do acorde de Si maior com sétima $\left(\mathrm{V}^{2}\right)$ por vários compassos. Além disso, ocorre uma mudança abrupta de dinâmica, uma vez que o plano em piano desencadeia no forte inesperado do segundo acorde da variante $\left(\mathrm{V}^{2}\right.$ no compasso 143$)$, associado ainda a uma troca de registro da mão esquerda em uma oitava mais grave neste momento. A passagem introduz uma significativa alteração no gesto musical, uma vez que a mão direita passa a realizar arpejos com ampla exploração do registro do instrumento ${ }^{17}$.

Outras passagens similares a esta da Fantasia Op. 49 são freqüentes na música de Chopin e usualmente desempenham troca do gesto musical e/ou dinâmica, tais como o Noturno Op. 62 no 2 (comps. 46 -47), o Noturno Op. 32 no 1 (comps. 60 -62), o Estudo Op. 25 no 10 (comps. 25 - 27).

A terceira possibilidade listada para a variante de Chopin prevê o emprego do acorde menor em estado fundamental como primeira tipologia. Embora este padrão no repertório não seja tão freqüente, se comparada às outras possibilidades, sua presença nesta listagem se justifica pela manutenção da sonoridade e principalmente pela observação da condução de vozes. O exemplo a seguir demonstra este uso na Mazurka Op. 41 no 2 nos compassos 56 - 57 (Ex. 72).

Exemplo 72 - Mazurka Opus 41 no 2: comps. 51- 62

Variante Chopin

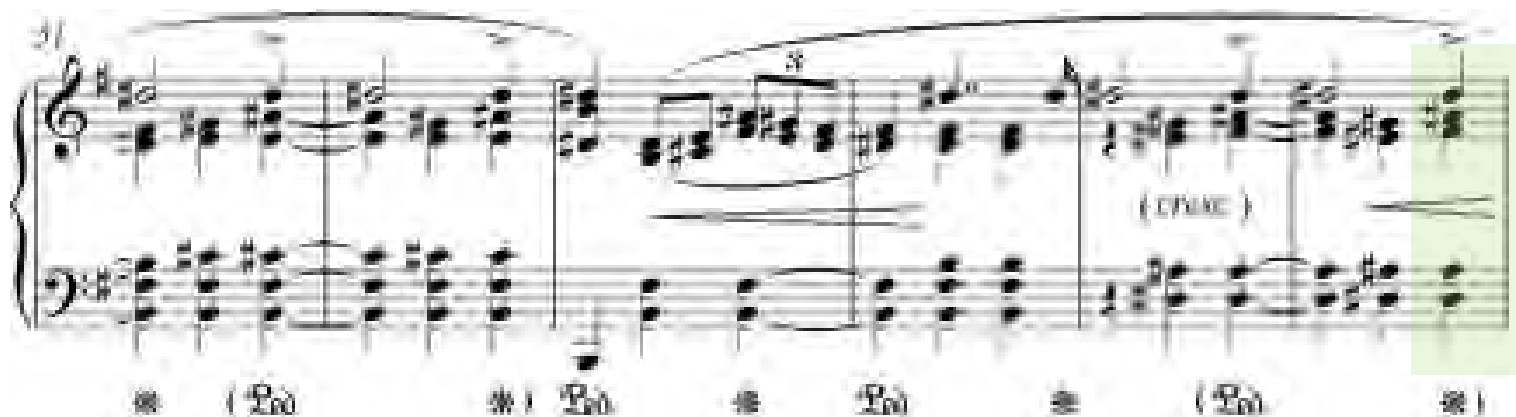

$\mathrm{m}$

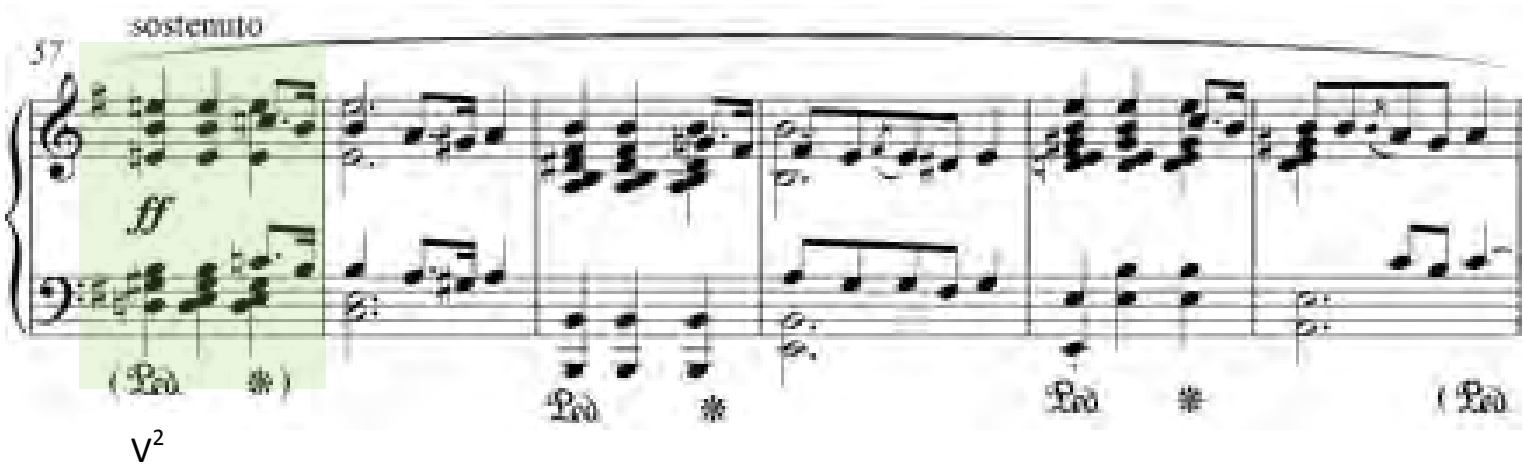

17 Esta passagem também assume outras funções musicais no contexto da fantasia, que serão apresentadas no último capítulo desta dissertação. 


\section{Redução: variante de Chopin}

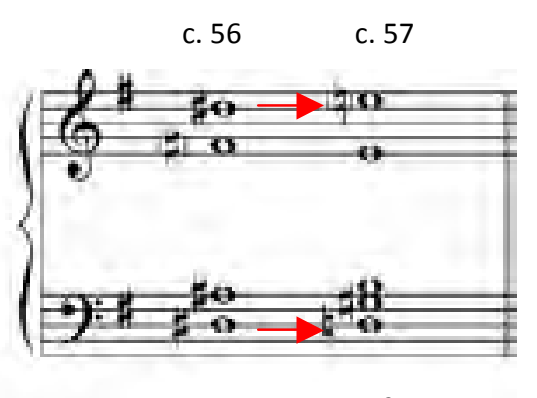

m $\quad V^{2}$

Nesta mazurka a chegada ao segundo acorde da variante ( $V^{2}$ no compasso 57) apresenta uma chave de crescendo que culmina em uma dinâmica $f f$, vinculada ainda a uma indicação de sostenuto.

Todos os exemplos apresentados até agora se referem às diferentes formas de apresentação da variante de Chopin que possuem vínculo auditivo com a versão B do Teufelsmühle $e^{18}$.

Para aclarar a relação da variante de Chopin com as sequências do Teufelsmühle, o exemplo 73 irá demonstrar de que forma estas estruturas estão interligadas. Neste exemplo, a versão B é apresentada em sua forma original e seguida por algumas de suas variantes: a substituição do acorde menor com quarta e sexta pelo acorde de dominante sem ou com sétima $^{19}$, assim como pelo acorde menor em estado fundamental ${ }^{20}$. As três possibilidades da variante de Chopin são expostas e relacionadas à versão $B$, como uma espécie de fragmento de uma estrutura maior. Assim, os três casos traduzem algumas das possibilidades de alterações previstas no Teufelsmühle. Contudo, tanto o primeiro quanto o segundo caso possuem uma relação mais estreita com a versão $B$, uma vez que a substituição do acorde menor com quarta e sexta por $\mathrm{V}$ ou $\mathrm{V}^{7}$ preserva a função de dominante. Já no último caso, a variante de Chopin derivada da alteração do Teufelsmühle que substitui o acorde menor com quarta e sexta por um em estado fundamental implica na troca de função. Isto acarreta num distanciamento do modelo mas não em uma ruptura com a sonoridade, visto que o vínculo é mantido por meio da manutenção da mesma fundamental e da condução de vozes.

\footnotetext{
${ }^{18}$ Cabe lembrar que a sonoridade da versão B do Teufelsmühle é muito aparentada a do omnibus.

${ }^{19}$ Cf. capítulo 3, item 3.3.1.

${ }^{20}$ Cf. capítulo 1, item 1.4.3.
} 
Exemplo 73 - Teufelsmühle e a variante de Chopin
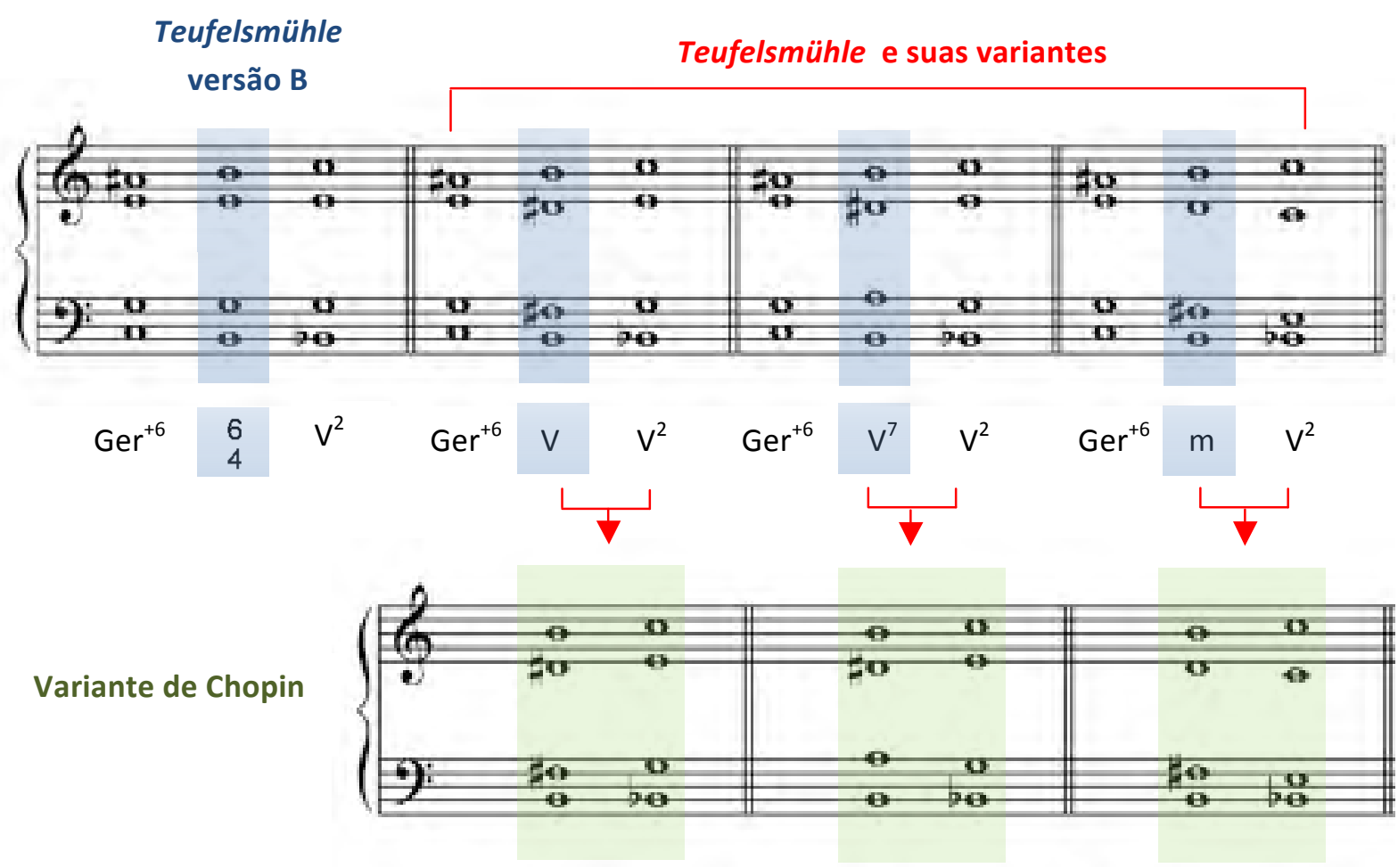

$$
\begin{array}{lllll}
\mathrm{V} & \mathrm{V}^{2} & \mathrm{~V}^{7} & \mathrm{~V}^{2} & \mathrm{~m}
\end{array}
$$

Ainda outra variante de Chopin pode ser observada no repertório, trata-se de um fragmento formado pelas tipologias $V^{7} e^{0} 7$, que mantém a condução de vozes característica dos modelos cromáticos e que sustenta a argumentação de uma derivação da versão $A$ do Teufelsmühle (Ex. 74).

Exemplo 74 - Teufelsmühle versão A e a variante de Chopin

Teufelsmühle versão A

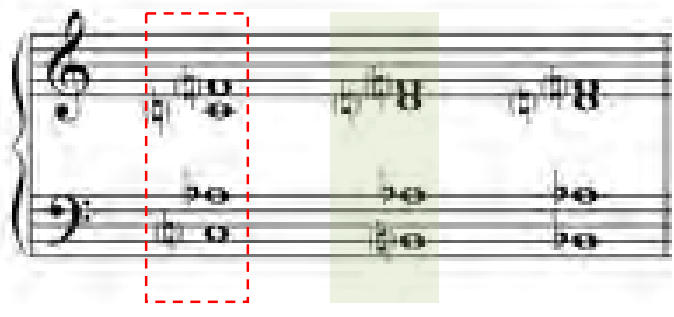

$\begin{array}{lll}6 & \mathrm{~V}^{7} \\ 4 & { }^{7}\end{array}$

\section{Variante de Chopin}

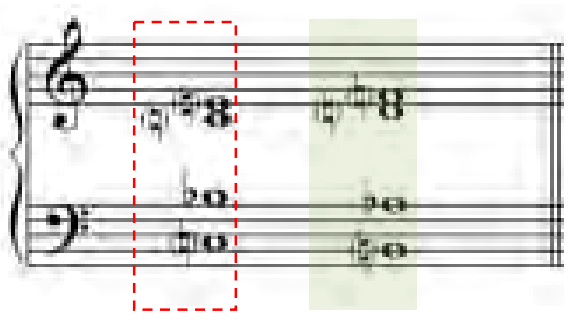

$\mathrm{V}^{7} \quad{ }^{0} 7$

4 
Uma comparação da versão A com a variante de Chopin do exemplo 74 permite notar que a substituição do acorde menor com quarta e sexta do padrão pela dominante com sétima preserva novamente a função harmônica, a fundamental do acorde e a condução de vozes.

O trecho a seguir, extraído da Sonata Op. 65 para violoncelo e piano, exemplifica o emprego desta nova apresentação da variante de Chopin nos compassos 87 - 88 (Ex. 75).

Exemplo 75 - Sonata Op. 65 para violoncelo e piano, 1으., comps. 84 - 92
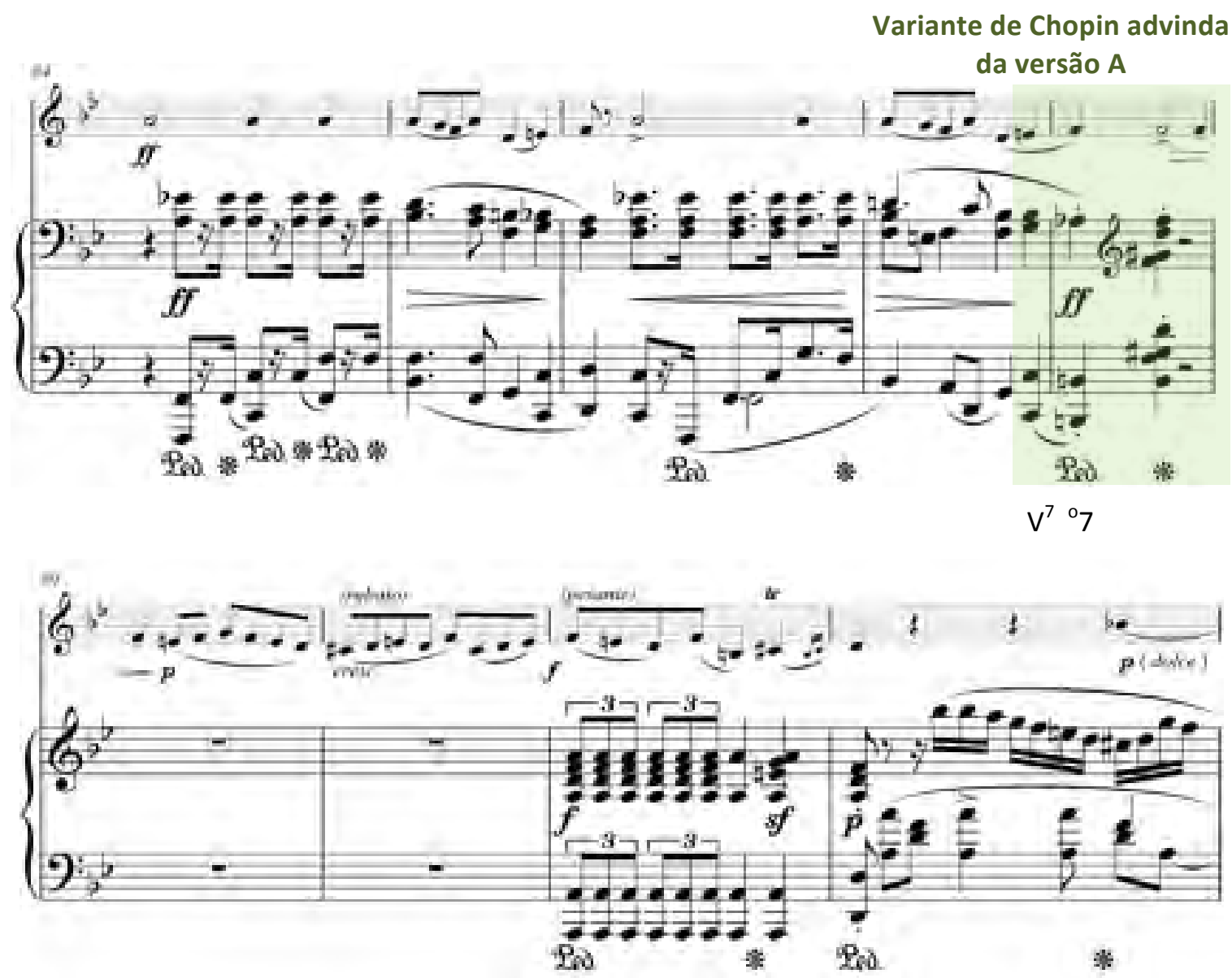

Redução: variante de Chopin

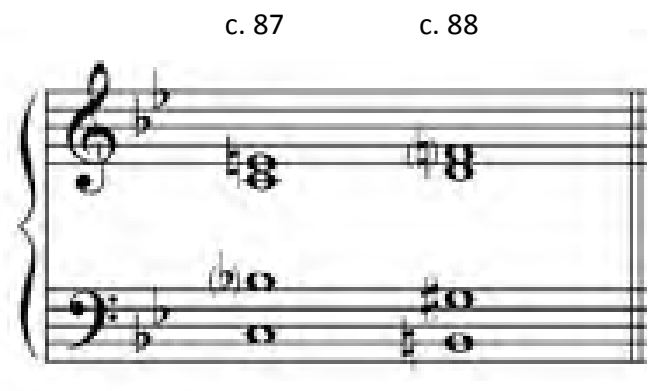

$V^{7} \quad{ }^{0} 7$ 
Na redução dos compassos 87 - 88 desta sonata o baixo realiza o cromatismo descendente (Dó - Si) enquanto que a outra fundamental (nota Dó), por movimento contrário, sobe para Ré, em conformidade com o modelo original da versão $A$ do Teufelsmühle. As duas vozes restantes (Sib e $\mathrm{Mi}$ ) resolvem por movimento contrário. Inserida no momento com dinâmica ff, no compasso 88 esta variante de Chopin introduz um solo do violoncelo em uma dinâmica piano.

Ilustrações deste procedimento ocorrem em toda a sua obra, de forma que estes fragmentos freqüentemente desempenham grandes contrastes, usualmente em mudanças repentinas de atmosferas, muitas vezes indicadas com alterações de dinâmica e gesto musical, o que permite entender que esta progressão possuía, de fato, um significado relevante em seu discurso.

Entretanto, devido ao elevado grau de elaboração da música de Chopin, no que diz respeito principalmente às variadas organizações das alturas e dissimulações por meio de figurações melódicas, uma identificação da condução das linhas da variante requer uma atenção maior, assim como determinadas passagens com o Teufelsmühle e omnibus já descritas.

Feita esta exposição, para finalizar este capítulo, torna-se relevante mencionar que esta sonoridade aqui nomeada como variante de Chopin não é algo exclusivo do compositor polonês. Assim, este fragmento já ocorre em Bach, como na Fantasia cromática em Ré menor BWV 903 (Ex. 76). Nesta obra são observadas as mesmas tipologias e condução de vozes que caracterizam o padrão $\mathrm{V}^{7}-\mathrm{V}^{2}$ demonstrado em vários exemplos deste item.

Exemplo 76 - J. S. Bach: Fantasia Cromática em Ré menor BWV 903, comps. 58 - 61

\section{Variante de Chopin}

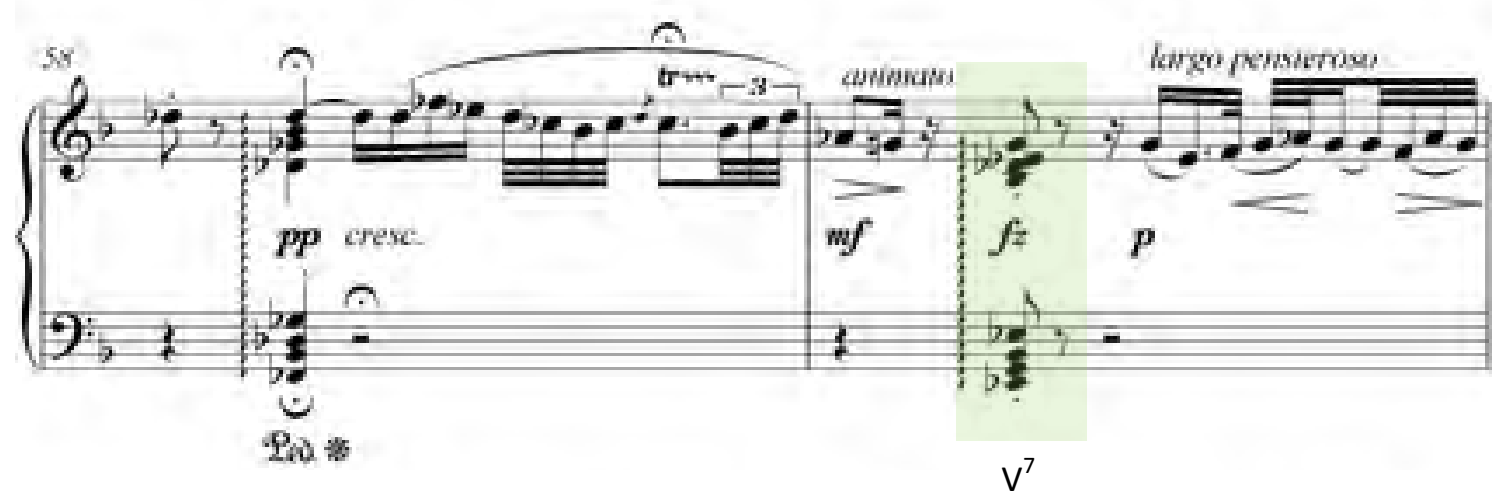




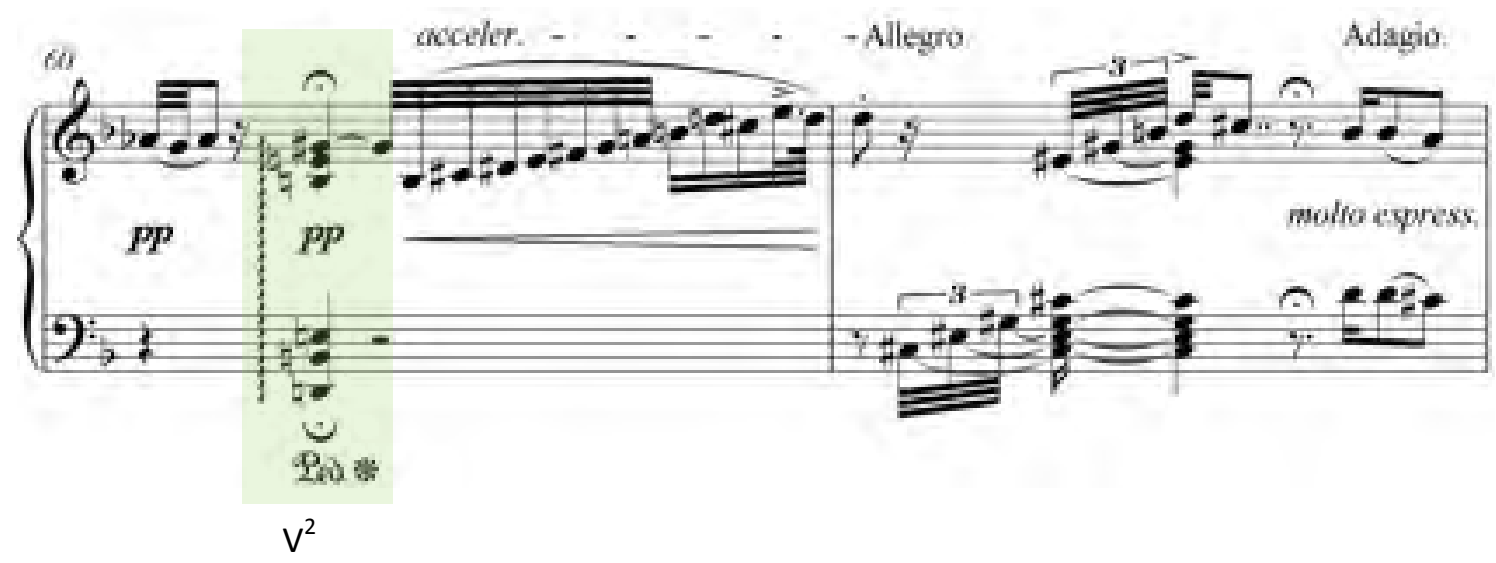

\section{Redução: variante de Chopin}

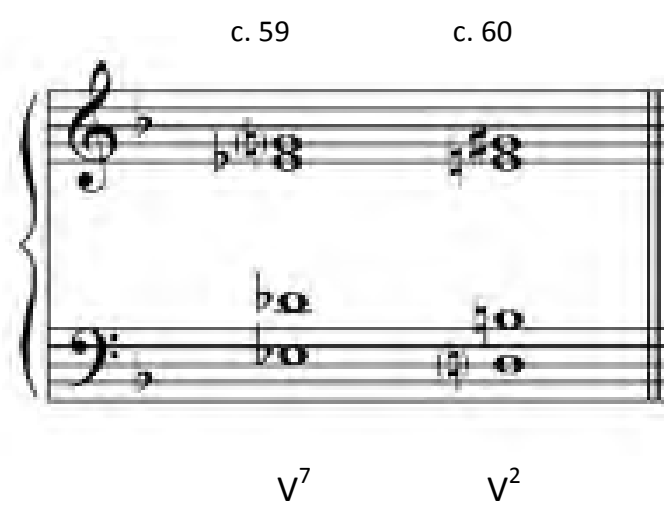

Além disso, é curioso notar que o fragmento na fantasia de Bach também é utilizado como um gesto harmônico que imprime mudanças de caráter e dinâmica, ou seja, de forma muito similar aos exemplos encontrados em Chopin.

É sabido sobre a admiração de Chopin por Bach, mas até que ponto o mestre polonês teria sido influenciado pelo consagrado compositor setecentista é uma questão que terá que ficar, por enquanto, sem resposta. 


\section{CAPÍTULO 4}

\section{Contextos musicais}

O emprego do Teufelsmühle e omnibus na prática composicional requer um estudo mais aprofundado, que permita a identificação estrutural e a observação do contexto em que os modelos cromáticos estão inseridos na obra. Nesta perspectiva, Dittrich elabora em seu artigo três possibilidades de classificações destas sequências, que serão igualmente assumidas por esta pesquisa: associação com incerteza, melancolia, tristeza e morte; passagens não temáticas; e contraste para preparação de ponto culminante (DITTRICH, 2007, p. $116-119)^{1}$.

É importante esclarecer, primeiramente, que embora estas divisões sejam advindas de uma exposição feita pela pesquisadora alemã, o reconhecimento do uso do Teufelsmühle relacionado à morte e incerteza, assim como ao ponto culminante de uma obra já fora destacado por Seidel, Telesco e Yellin, da mesma forma que passagens não temáticas também já foram sublinhadas no artigo "Enharmonicism and the Omnibus Progression in Classical-Era Music" ${ }^{2}$. Entretanto, a sistematização proposta por Dittrich permitiu uma visão geral das propriedades assumidas por estas sequências cromáticas de forma comentada e ilustrada em exemplos da literatura musical.

Assim, este capítulo irá se concentrar no estudo de contextos relacionados ao uso do Teufelsmühle e omnibus que abarcam a observação, descrição e análise de elementos de naturezas diversas, tais como andamento, dinâmica, textura, forma, harmonia e condução de vozes, etc. As divisões a seguir se tornam úteis para facilitar uma primeira exposição acerca deste assunto, no entanto, vale ressaltar que os exemplos musicais que serão demonstrados podem se adequar, de forma concomitante, nas diferentes classificações.

\footnotetext{
${ }^{1}$ Outro tipo de emprego destas estruturas cromáticas foi observado por Elmar Seidel, que concluiu sobre a possibilidade do uso do Teufelsmühle ou derivados dele como elemento temático de uma obra (SEIDEL, 1981, p. 176).

${ }^{2}$ Cf. Telesco (1998, p. 245 - 247).
} 


\section{1 - ASSOCIAÇÃO COM INCERTEZA, MELANCOLIA, TRISTEZA E MORTE}

Tanto a corrente alemã quanto a americana possui pesquisas que estabelecem um vínculo, em determinados casos, entre as progressões do Teufelsmühle ou do omnibus ao contexto de incerteza, melancolia, tristeza e morte. Neste sentido, os estudos de Seidel promovem, sobretudo, uma associação dos modelos do Teufelsmühle com uma figura retórica do Barroco, como será ilustrado adiante. Paralelamente, a investigação de Telesco busca uma compreensão mais estreita entre o emprego da progressão e o impacto dramático que esta estrutura poderia evocar. Seus textos relacionam as progressões do omnibus ou Vogler-omnibus ao baixo da passacaglia e à Aria da Lamento.

Dentro deste item são encontradas tanto obras que possuem o vínculo com a palavra como peças puramente instrumentais. Entre os exemplos enumerados por Dittrich destacam-se a Criação de Haydn, as óperas Freischutz de Weber e Don Giovanni de Mozart, bem como no último movimento do Quarteto Op. 18 no 6 de Beethoven, intitulado La Malinconia - "a melancolia"

Neste momento torna-se oportuno retomar os exemplos 52 e 56 apresentados no segundo capítulo, para esclarecer que os modelos cromáticos nestes dois Lieder de Schubert também estão intimamente relacionados à idéia de morte, de acordo com os respectivos textos poéticos.

Em Chopin, a associação do Teufelsmühle e omnibus com este tópico será proposta na Melodia Op. 74 no 9 e no Prelúdio Opus 28 no 2, uma vez que constituem exemplos em que os modelos são empregados de forma particular, além de ilustrarem o gênero vocal e instrumental, respectivamente.

A Melodia Op. 74 no 9 foi composta sobre um mote de sete versos do poema Ostatni ["O Último"] de Zygmunt Krasinski, que narra a experiência de um conspirador polonês patriota, preso em casamatas na Rússia devido às suas atividades de conspiração ${ }^{4}$. 0 texto usado por Chopin, bastante imbuído do presságio da morte, demonstra um vínculo direto com este primeiro item, conforme pode ser constatado no fragmento original em polonês a seguir, acompanhado de sua respectiva tradução (Ex. 77).

\footnotetext{
${ }^{3}$ Cf Dittrich (2007, p. 117). Vale ressaltar que Victor Yellin também associa as óperas Don Giovanni de Mozart e Freischutz de Weber à atmosfera de dramaticidade (1998, p. 18 - 19 e 30 - 31). Para uma análise mais detalhada do finale do segundo ato de Don Giovanni (comps. 494 - 501), cf. Telesco (1998, p. 264 - 266).

${ }^{4}$ Tanto Ostatni quanto a Melodia Op. 74 no 9 foram escritas em 1847 e tiveram notável destaque nesta década, marcada pela "Grande Emigração" polonesa.
} 


\section{Exemplo 77 - Texto original e tradução}

Z gór, gdzie dźwigali strasznych krzyżów brzemię

Widzieli z dala obiecaną ziemię

Widzieli światło niebieskich promieni

Ku którym, w dole, ciągnęło ich plemię.

A sami do tych nie wejdą przestrzeni,

Do godów życia nigdy nie zasiędą

I może nawet - zapomnieni będą!
Das montanhas, de onde eles carregaram o terrível fardo das cruzes

Eles viram à distância a terra prometida

Eles viram a luz de raios celestes

Para a qual, no vale, sua tribo ansiava.

E eles não alcançariam este espaço,

Nunca iriam saborear as delícias da vida,

E talvez até mesmo - serão esquecidos!

Do ponto de vista musical, a dramaticidade contida na poesia é ressaltada pela ambigüidade tonal, uma das características estruturais predominante nesta peça, que promove ainda, em diferentes níveis, uma contínua instabilidade desde a introdução da música. Desta forma, já inicialmente a tonalidade da peça não é revelada, uma vez que os compassos 1 - 2 sugerem SolM, seguidos pelos compassos 3 -4, que reapresentam o mesmo conteúdo em FáM. Apenas no quinto compasso ocorre o anúncio do tom principal (Mi menor) com uma cadência suspensiva no momento em que inicia a parte da voz (Ex. 78).

Exemplo 78 - Melodia Op. 74 no 9: comps. 1 - 5

cadência suspensiva

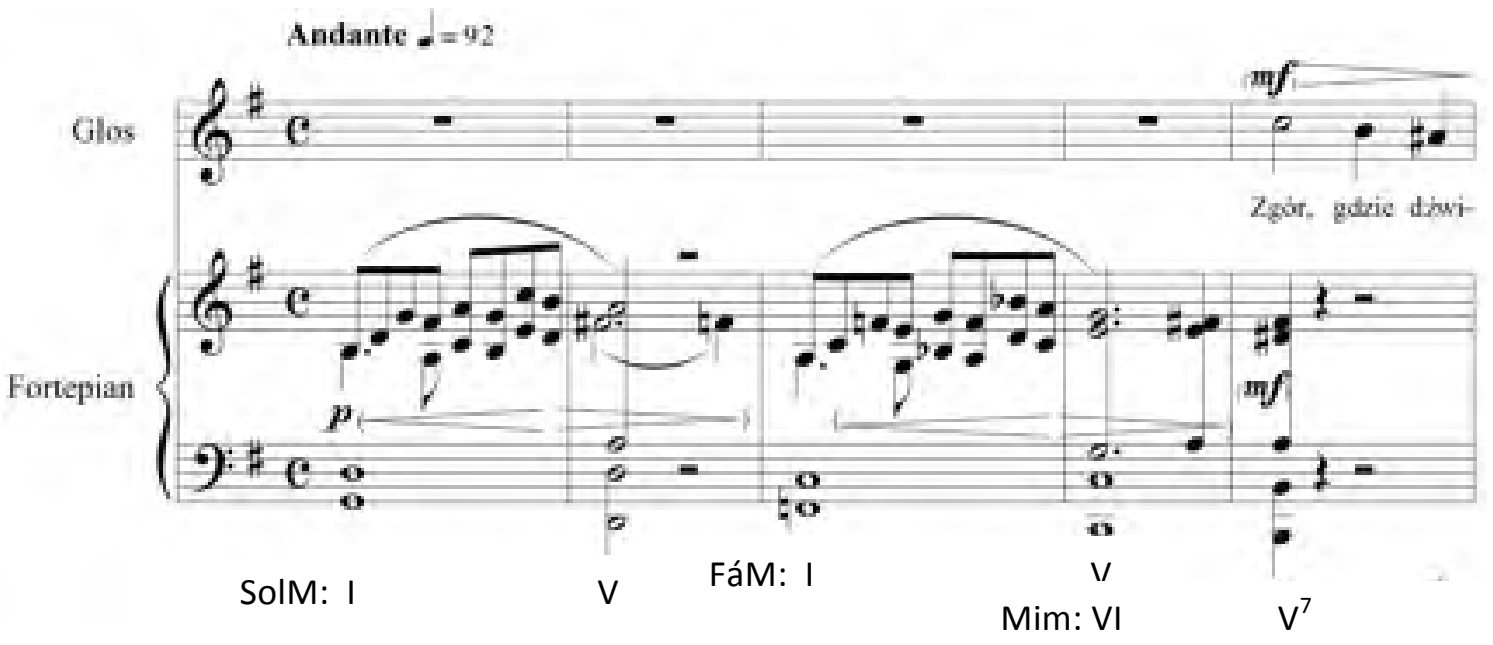


Do compasso 5 em diante a tonalidade se estabiliza em Mi menor, até que no compasso 11 Chopin surpreende com a mistura de modos, que é confirmada por uma cadência autêntica perfeita em Mi maior no compasso 13, exatamente na passagem do poema em que a terra prometida é vislumbrada.

Outro momento característico de ambigüidade harmônica ocorre no compasso 16, com a reinterpretação do acorde de $\mathrm{Mi}^{7}\left(\mathrm{~V}^{2} / \mathrm{IV}\right)$ como $\mathrm{Ger}^{+6}$ em LábM, tonalidade que se vincula ao tom de Mi menor/maior por relação de mediante (Ex. 79). A observação do texto permite relacionar a chegada deste novo direcionamento harmônico no compasso 17 ao emprego da palavra światło [luz], assinalada em azul.

Exemplo 79 - Melodia Op. 74 no 9: comps. 13 - 20

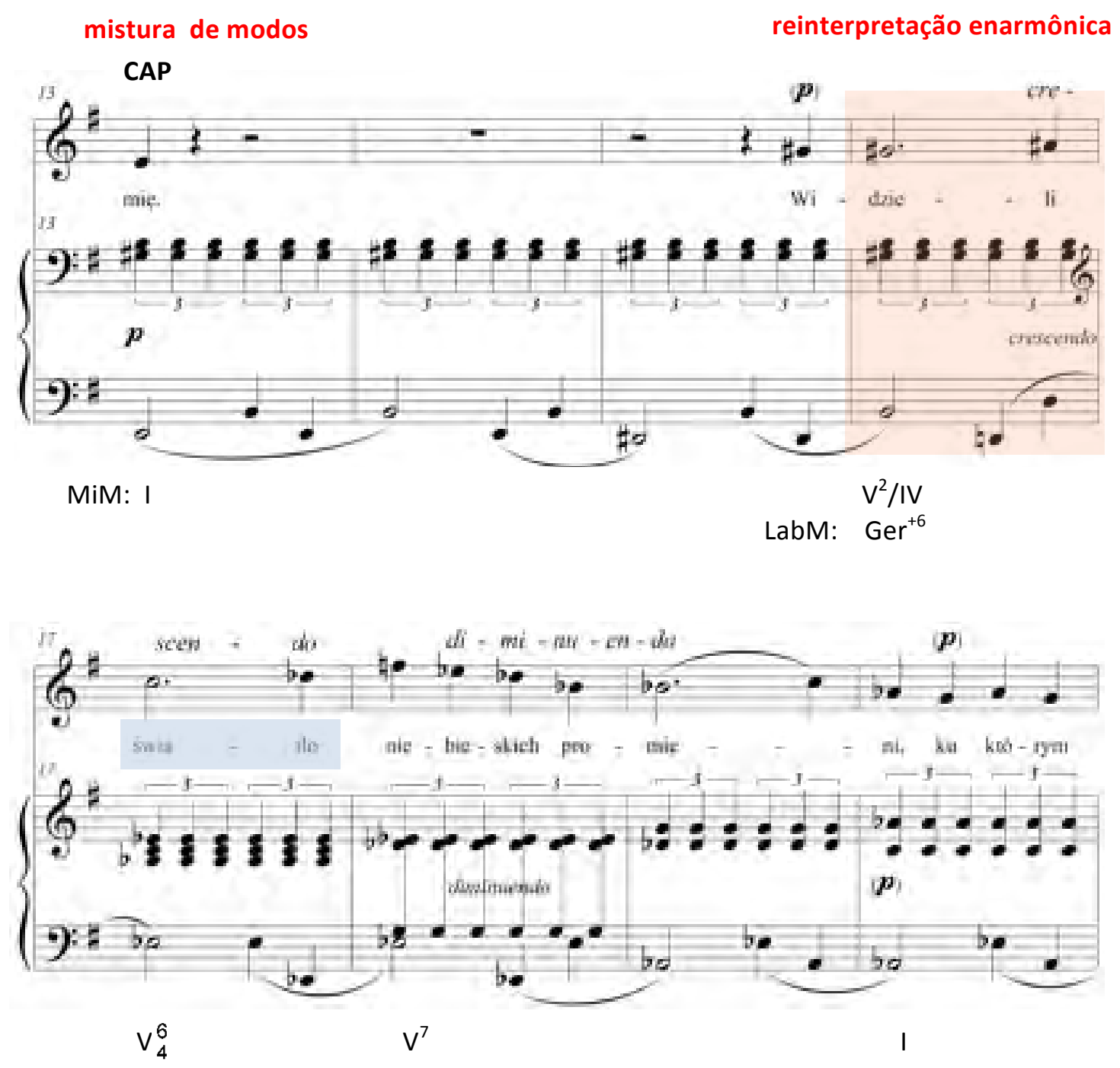


Num contexto sem nenhuma definição cadencial, o Teufelsmühle/omnibus é empregado de forma ampla e com variantes por treze compassos (25 - 37), numa passagem de absoluta ambigüidade harmônica, em uma espécie de "parênteses tonal" (Ex. 80). Estes aspectos estruturais possuem uma estreita correspondência com o conteúdo poético, que exprime a idéia de angústia, incerteza e morte nos três últimos versos: "e eles não alcançariam este espaço; nunca iriam saborear as delícias da vida; e talvez até mesmo serão esquecidos".

Exemplo 80 - Melodia Op. 74 no 9: comps. 25 - 37

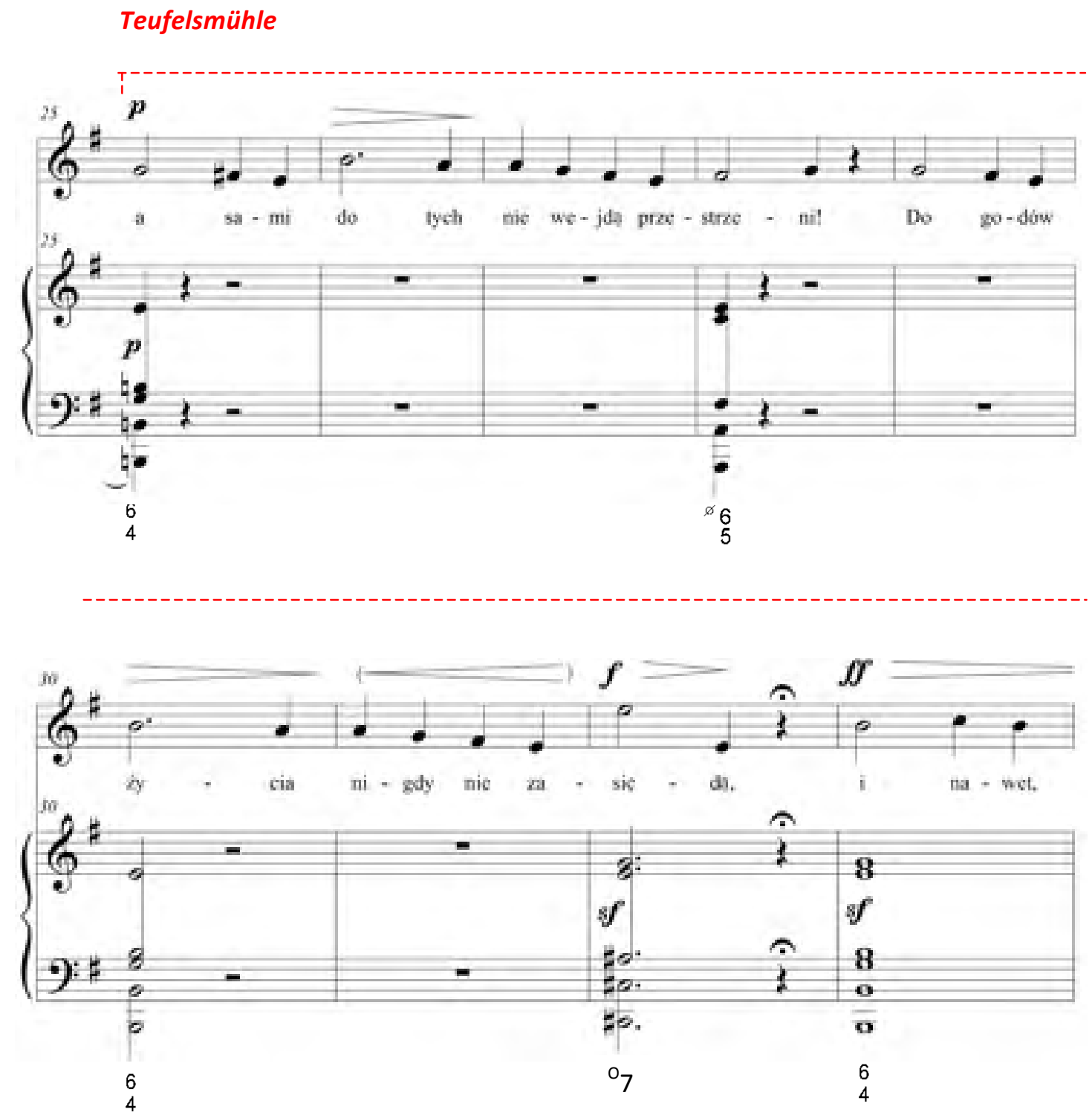




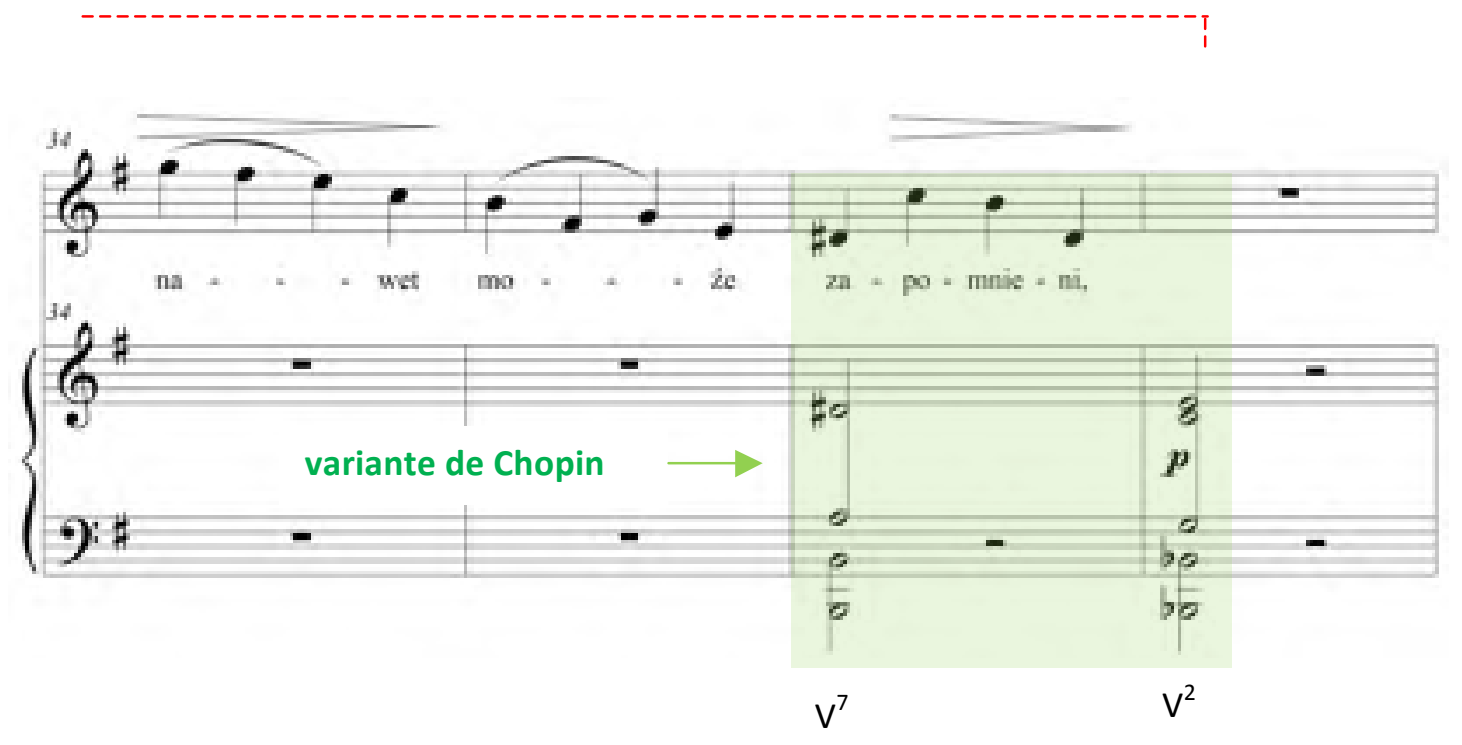

O reconhecimento dos modelos nesta peça não é evidente, uma vez que ocorrem alterações em relação ao Teufelsmühle, que tornam a linha cromática do baixo obscurecida por conta de seu sucessivo movimento ascendente e descendente, além da omissão de vários acordes. Assim, com a finalidade de auxiliar a identificação dos elementos da sequência no trecho musical, o exemplo 81 apresenta a redução da passagem citada acima, acompanhada pela classificação das tipologias dos acordes e de uma interpretação, para efeito de comparação, como Teufelsmühle versão $A B$ ou como omnibus, ambos com variantes. Neste exemplo, a sinalização em cores das variantes permite observar suas respectivas procedências em relação às versões de Seidel. A única substituição de acorde ocorre com o Fá\# meio diminuto no compasso 28, empregado no lugar do Lá maior com sétima menor previsto na versão B do Teufelsmühle ${ }^{5}$.

É curioso notar que o acorde Dó maior com sétima menor, assinalado em vermelho e entre colchetes no exemplo 81, é evitado durante toda a passagem. Assim, esta tipologia é reservada para o momento de grande contraste musical que irá ocorrer no compasso 37, a variante de Chopin.

\footnotetext{
${ }^{5}$ Uma explicação de acordo com a visão alemã talvez seja mais adequada neste caso, por conter apenas esta substituição de acorde em relação às versões de Seidel, enquanto que uma explanação na perspectiva americana prevê ainda outra alteração de tipologia de acorde do padrão clássico no compasso 32.
} 
Exemplo 81 - Melodia Op. 74 no 9: redução

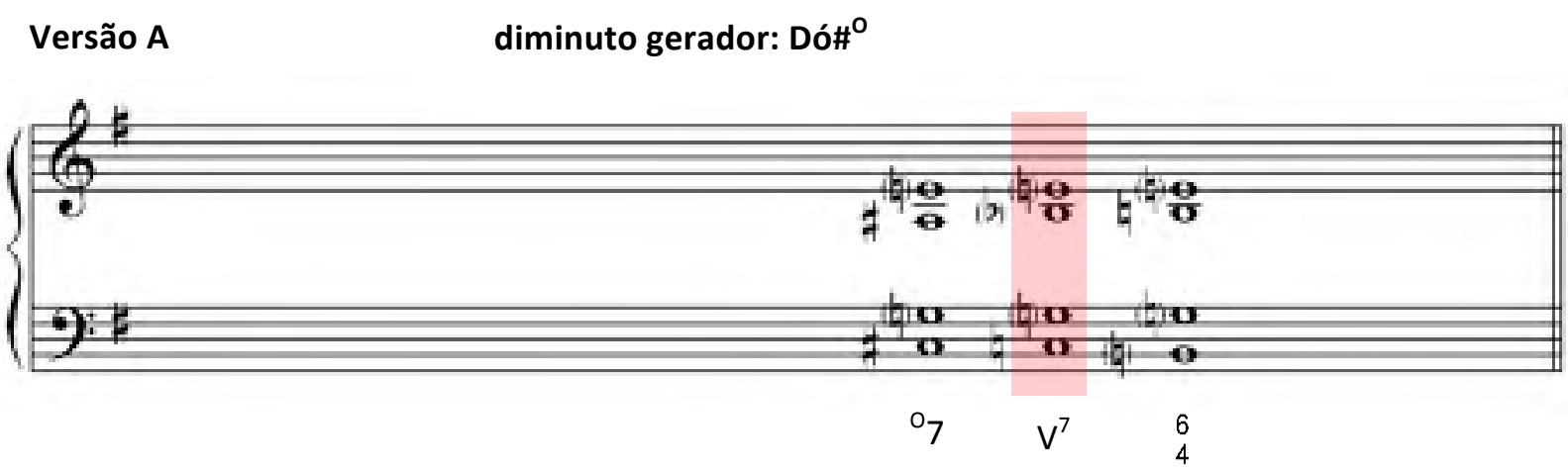

Versão B

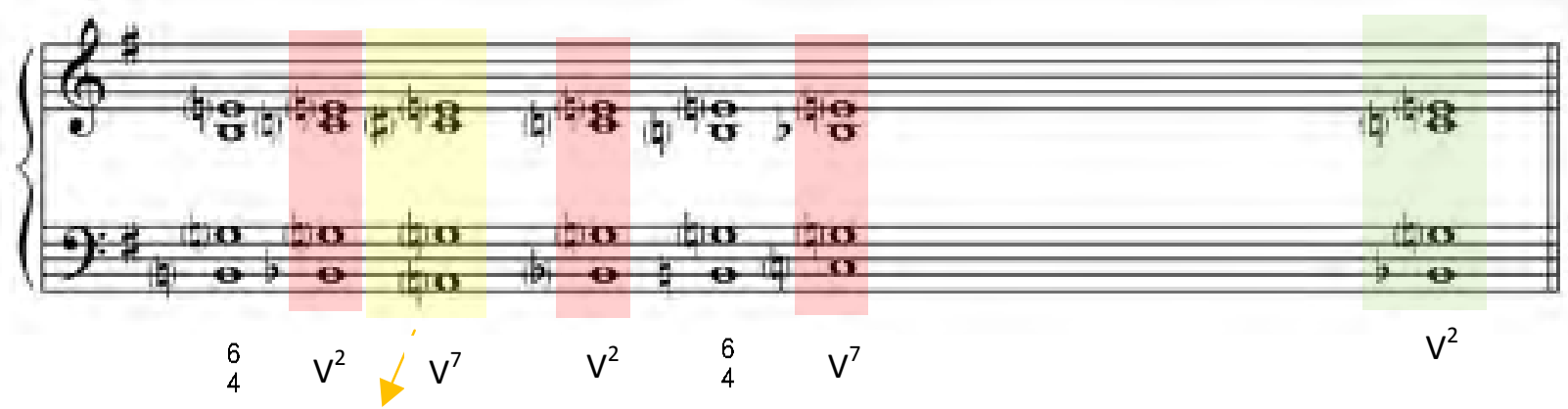

Op. 74 no 9 Substituição de acorde em relação ao padrão

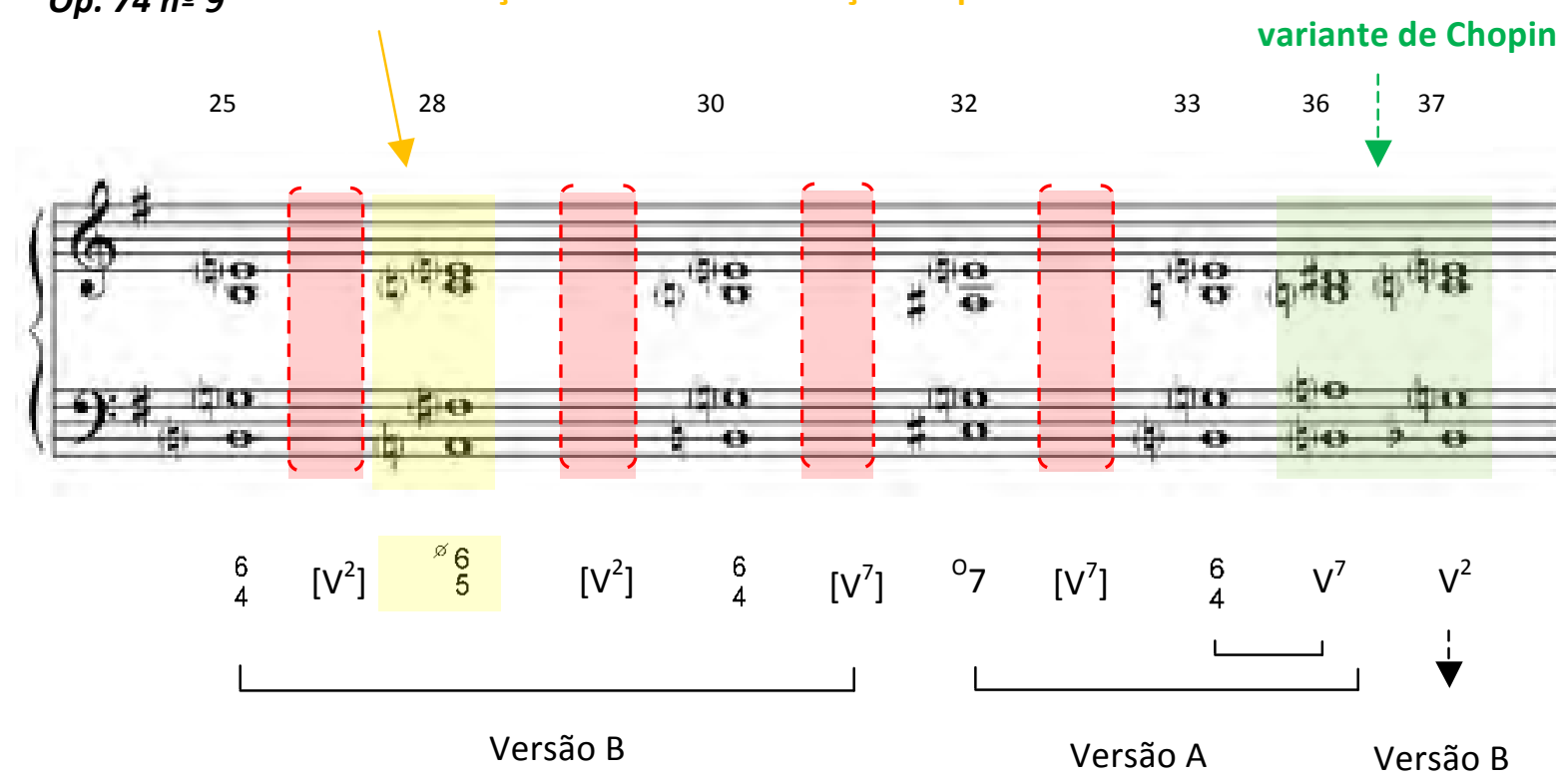

Teufelsmühle: versões A e B com variantes
(3) [(4)] [5)]
[4]
(3) [2]
[1)] [2]
(3) [3]
(4)

Omnibus: O (Mi-Sol) com variantes 
$\mathrm{Na}$ passagem entre os compassos 36 e 37 da canção, a variante de Chopin é empregada como um recorte do Teufelsmühle/omnibus e fica evidente sua incorporação como um gesto harmônico em seu vocabulário sonoro ${ }^{6}$. É importante observar que neste momento ocorre uma inversão entre a voz e o piano, visto que a linha do canto silencia no compasso 37 e ocorre uma contrastante mudança de dinâmica de fortíssimo para piano no instrumento, o que explicita mais uma vez o poder expressivo desta variante, que culmina com o fechamento do conteúdo poético sobre a palavra "zapomnieni" [esquecidos], cf. exemplo 80.

Complementando este item, uma abordagem sobre o Prelúdio Op. 28 no 2 pretende vincular vários pontos que corroboram a hipótese de que o Teufelsmühle nesta peça está inserido no contexto de incerteza, melancolia, dor e morte.

É comum encontrar os termos cromatismos, acordes enigmáticos, assim como o conceito de tonalidade expandida em referência ao $0 p .28 n^{\circ} 2^{7}$. Sob outra perspectiva, é possível também incorporar a estes aspectos harmônicos as questões lineares da composição, que no caso, assumem um papel decisivo na concepção desta obra, como observa Charles Rosen na citação a seguir:

[...] a linha sempre será, para Chopin, algo mais fundamental que a harmonia, e ele chega a Lá menor, principalmente, através das linhas de soprano e baixo [...] Nas passagens em que a textura e a harmonia parecem ser as mais radicais e mais ambíguas, o contraponto de Chopin é o agente controlador (2000, 137-138).

Embora o autor não identifique, nomeie ou faça qualquer menção às conexões com o Teufelsmühle, a ênfase que dispensa à polifonia está fundamentalmente de acordo com os princípios que norteiam os modelos cromáticos.

A presença do Teufelsmühle nos compassos 13 a 15 deste prelúdio coincide com o que Rosen chama de "momento crucial de transformação". O autor refere-se à passagem dos compassos 11 -15 como "uma poética misteriosa, sombria e comovente" (ROSEN, 2000, p. 138). Sua menção ao trecho contribui com a idéia de que, em determinados casos, os modelos cromáticos podem assumir um poder expressivo na obra musical. No entanto, é importante esclarecer que apenas estas descrições feitas por Rosen não são suficientes para

\footnotetext{
${ }^{6}$ O fato desta sonoridade se encontrar, por vezes, como parte do Teufelsmühle ou omnibus constitui também um argumento para fundamentar a hipótese de origem desta variante advinda dos modelos cromáticos (Cf. item 3.3 3).

${ }^{7}$ Cf. Kostka (2004, p. 458 - 459) e Green (1993, p. 91 - 92).
} 
sustentar uma argumentação de que esta peça está vinculada a este item proposto. Assim, a análise que será feita a seguir visa levantar e relacionar outros pontos que também incitam o contraste musical do Teufelsmühle neste prelúdio.

Primeiramente, uma interpretação analítica do Op. 28 no 2 permite considerá-lo como uma organização muito elaborada, que integra diferentes "acontecimentos" musicais

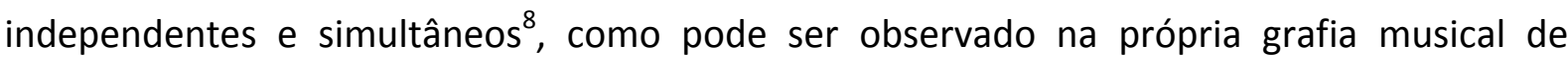
Chopin (Ex. 82c). Os compassos iniciais já apresentam, na mão esquerda, dois elementos que irão constituir a peça como um todo. O primeiro pode ser subdividido em duas vozes: o baixo, nota Mi, e um plano mais agudo, nota Sol (Ex. 82a). O outro, de natureza melódica, na voz intermediária, assumirá o papel de fio condutor da peça (Ex. 82b).

\section{Exemplo 82 - Compassos iniciais, mão esquerda: comps. 1 - 2}

a) Baixo e plano mais agudo

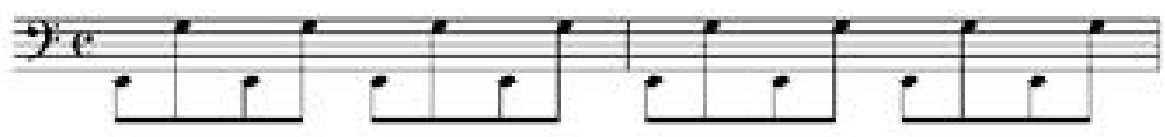

b) Elemento de natureza melódica: voz intermediária

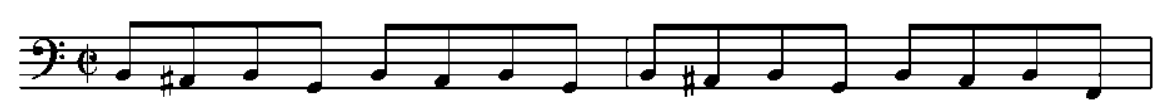

c) Trecho original

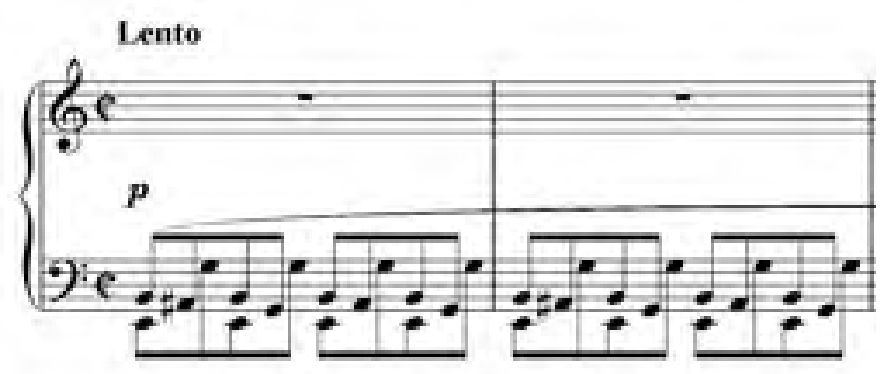

\footnotetext{
${ }^{8}$ Segundo Willy Corrêa de Oliveira, quando se tem acontecimentos simultâneos cada voz não é apenas uma voz, é um elemento que tem vida própria e uma maneira particular de exprimir-se e de se desenvolver no decorrer da peça em um só eixo. Entretanto, ressalta que não basta que sejam acontecimentos diferentes, é necessário que haja um princípio unificador. Para mais informações sobre as definições destes conceitos e aplicações em análises da música de Chopin conferir Oliveira (2005, p. 11 - 18).
} 
A distinção destes diferentes eventos torna-se essencial para o entendimento das disposições das linhas que formam o Teufelsmühle neste prelúdio. Com uma única alteração em relação à versão $A$, assinalada em verde no exemplo seguinte, o fragmento é formado por três acordes: diminuto; substituição da sexta germânica pela sexta francesa; e acorde menor com quarta e sexta (Ex. 83).

Exemplo 83 - Prelúdio Op. 28 no 2: comps. 13 - 16

única nota variada em

relação à versão $A$

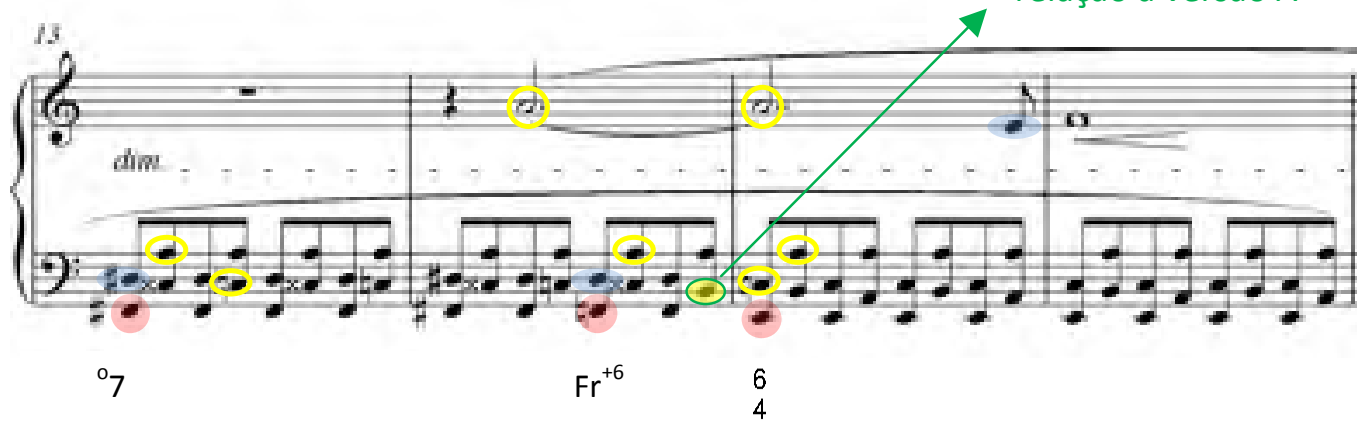

Redução: Versão A

Prelúdio

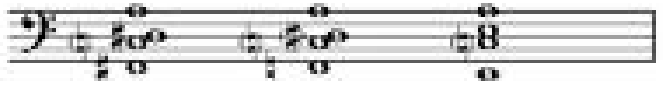

${ }^{\circ} 7$

$\mathrm{Ger}^{+6}$

C. 13

c. 14

C. 15

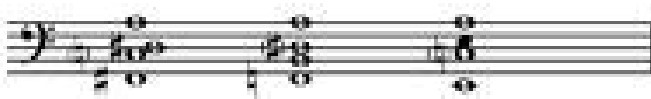

${ }^{0} 7 \mathrm{Fr} \quad 4$

No exemplo 83 as notas que constituem cada acorde do Teufelsmühle encontram-se assinaladas em cores: a linha cromática descendente do baixo em vermelho; o outro cromatismo ascendente que marca o movimento da sensível (Ré\# para Mi) em azul; e as notas do pedal (Lá e Dó) em amarelo, incluindo a nota Si resultante do uso da $\mathrm{Fr}^{+6}$, em verde. É possível então observar que algumas notas que integram os acordes do Teufelsmühle estão deslocadas ritmicamente na voz intermediária da mão esquerda por meio de figurações melódicas.

Cabe ressaltar que a linha do baixo, de forma geral, move-se muito pouco neste prelúdio: do compasso 1 ao 7 ocorrem apenas três alturas diferentes (Mi, Ré e Sol) e entre os compassos 8 - 12 somente duas (Si e Lá). Entretanto, no trecho seguinte, do compasso 13 ao início do compasso 14 são observadas, a cada mínima, as notas Fá sustenido, Fá natural e Mi natural. Desta forma, esta maior movimentação do baixo (comps. 13 e 14) está associada às trocas harmônicas da versão A do Teufelsmühle.

Além desta aceleração do ritmo harmônico, torna-se importante perceber de que maneira Chopin elabora esta estrutura musical. A linha melódica da mão direita no momento do Teufelsmühle permanece somente com a nota Lá natural do pedal, ou seja, 
produz um efeito contrário à sua natureza de se movimentar, fica estática. Além disso, vale também constatar que a presença da nota Si no compasso 14, única variação em relação à versão A, marca um significativo movimento cromático, com característica motívica, que borda e conduz à nota Dó imediatamente seguinte.

Talvez o uso do baixo cromático descendente neste contexto possa ser algum resquício de uma figura de expressão patética do Barroco associada à dor, tristeza e sofrimento. Esta hipótese levantada por esta pesquisa se deve aos paralelos estabelecidos, neste momento, com os estudos de Seidel, que apontam o uso da figura retórica da pathopoiia no recitativo no 73 da Paixão Segundo São Mateus (1727) de Bach, como confirma a seguinte citação:

Do exemplo de J. S. Bach [referindo-se a Paixão Segundo São Mateus], podemos dizer que aqui a utilização do modelo harmônico é influenciada por uma figura de expressão, a saber: a pathopoiia. Como é sabido, esta é uma figura por meio de cuja aplicação uma frase musical ou uma determinada passagem de uma frase é acentuada pateticamente. Ela [a pathopoiia] ocorre tanto ascendente como descendentemente na disposição dos sons cromáticos. Somente descendentemente ela está ligada à expressão da dor, da tristeza, do sofrimento (Lamento). Porém, também ascendentemente ela permanece como uma figura de expressão patética (SEIDEL, 1969, p. 291).

No exemplo 84 é possível observar o trecho extraído desta obra, no qual ocorre um fragmento da versão A sobre um baixo cromático ascendente, que Seidel relata como a ocorrência mais antiga encontrada em sua pesquisa (SEIDEL, 1981, p. 172) ${ }^{9}$. A passagem está inserida depois da crucificação, no momento da descida da cruz, sob as palavras "e a terra tremeu e os penhascos se romperam" do recitativo evangelista.

\section{Exemplo 84 - J. S. Bach: Paixão Segundo São Mateus, recitativo 73}

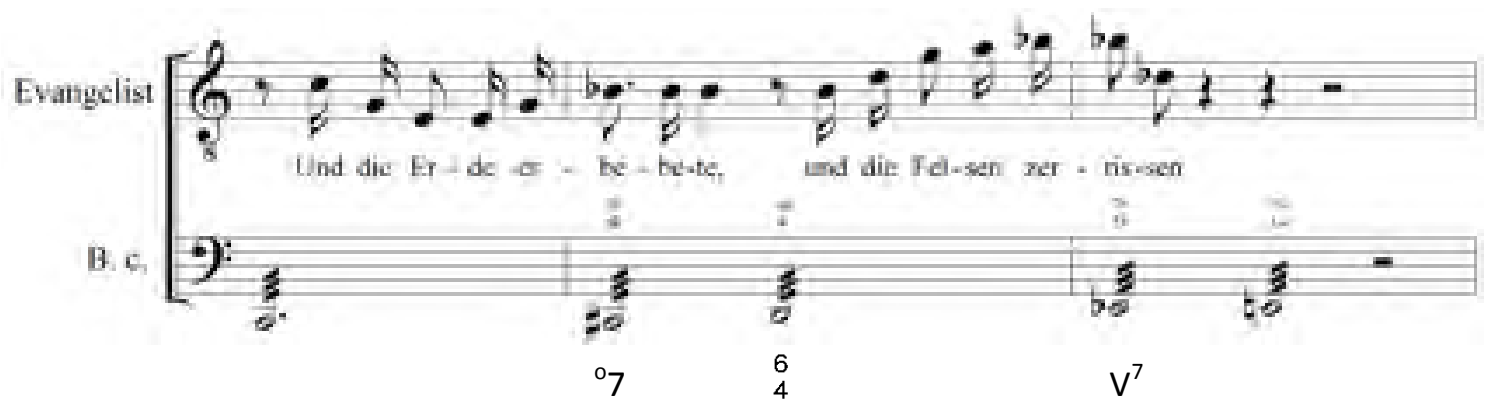

\footnotetext{
${ }^{9}$ Por outro lado, a americana Paula Telesco aponta que o exemplo mais antigo deste padrão localizado em sua investigação, até o momento, está na ópera Tamerlano (1724) de Haendel, mais especificamente na ária de Lamento "Sì, figlia, io moro" (TELESCO, 1998, p. 267).
} 
Além do vínculo com o cromatismo, outros aspectos musicais também podem estar relacionados à este primeiro item. É sabido que o andamento da música tem a possibilidade de influir no caráter da peça. Exemplos que ilustram esta questão são os termos Lento, Mesto e Largo, que têm uma tradição em representar um afeto de sofrimento (BROWN, 1999, p. 340). Nesta perspectiva, Telesco destaca uma "[...] associação de tristeza e sofrimento com os tempos lentos que tendem a acompanhar o cromatismo predominante no modo menor" (MEYER apud Telesco 1998, p. 253).

Retomando a exposição do Prelúdio $O p .28$ no 2, o andamento lento, a ambiguidade tonal da abertura, a tonalidade menor da peça podem incitar a relação com incerteza, melancolia, dor e morte. Outros pontos também podem sugerir tal relação: o baixo cromático descendente na entrada do Teufelsmühle, uma possível menção ao baixo de Lamento; o registro grave e a dinâmica cada vez mais decrescente, numa espécie de "ponto culminante às avessas“; além das sugestões de recitativos a partir do compasso 17 (Ex. 85).

\section{Exemplo 85 - Prelúdio Op. 28 no 2 na íntegra}
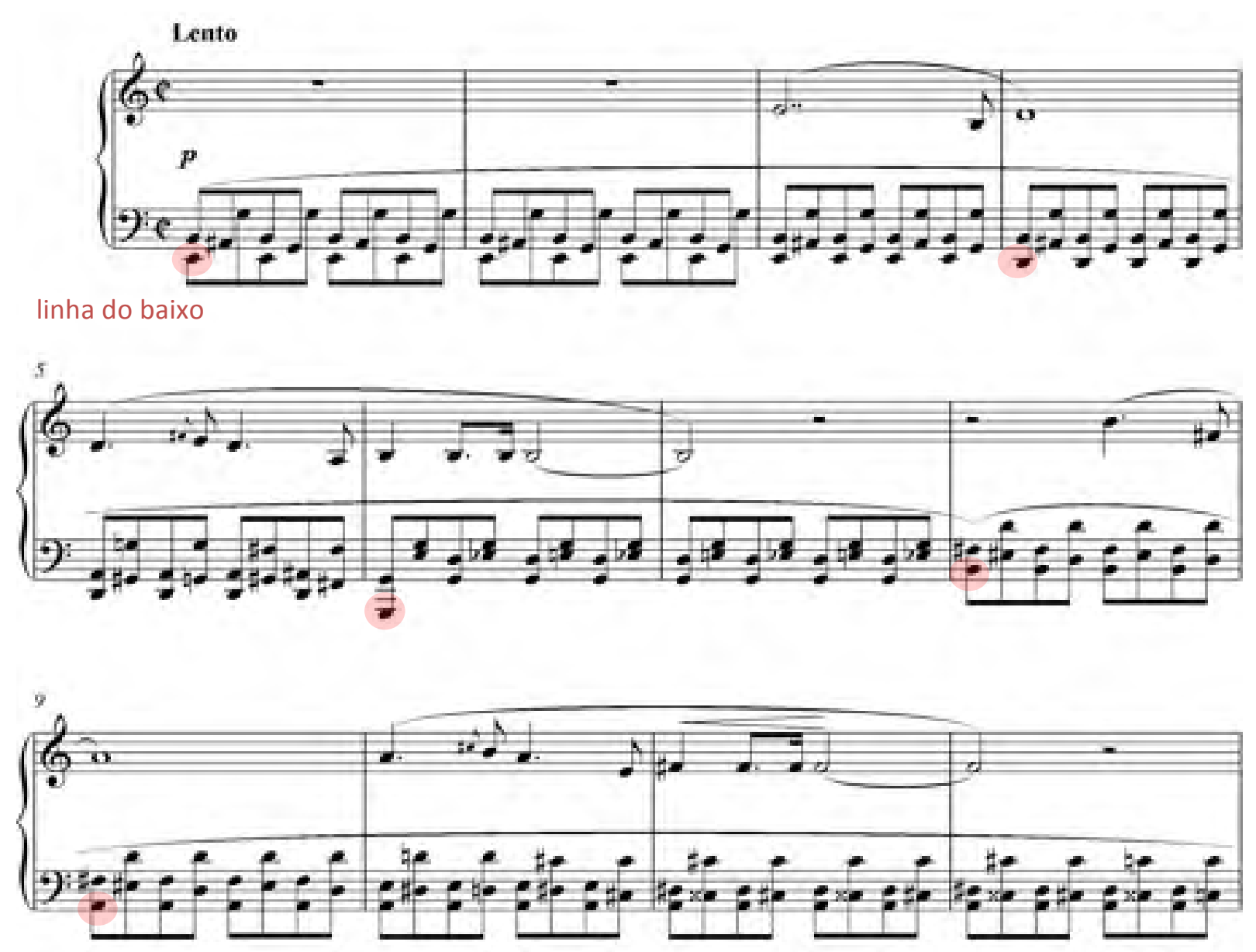


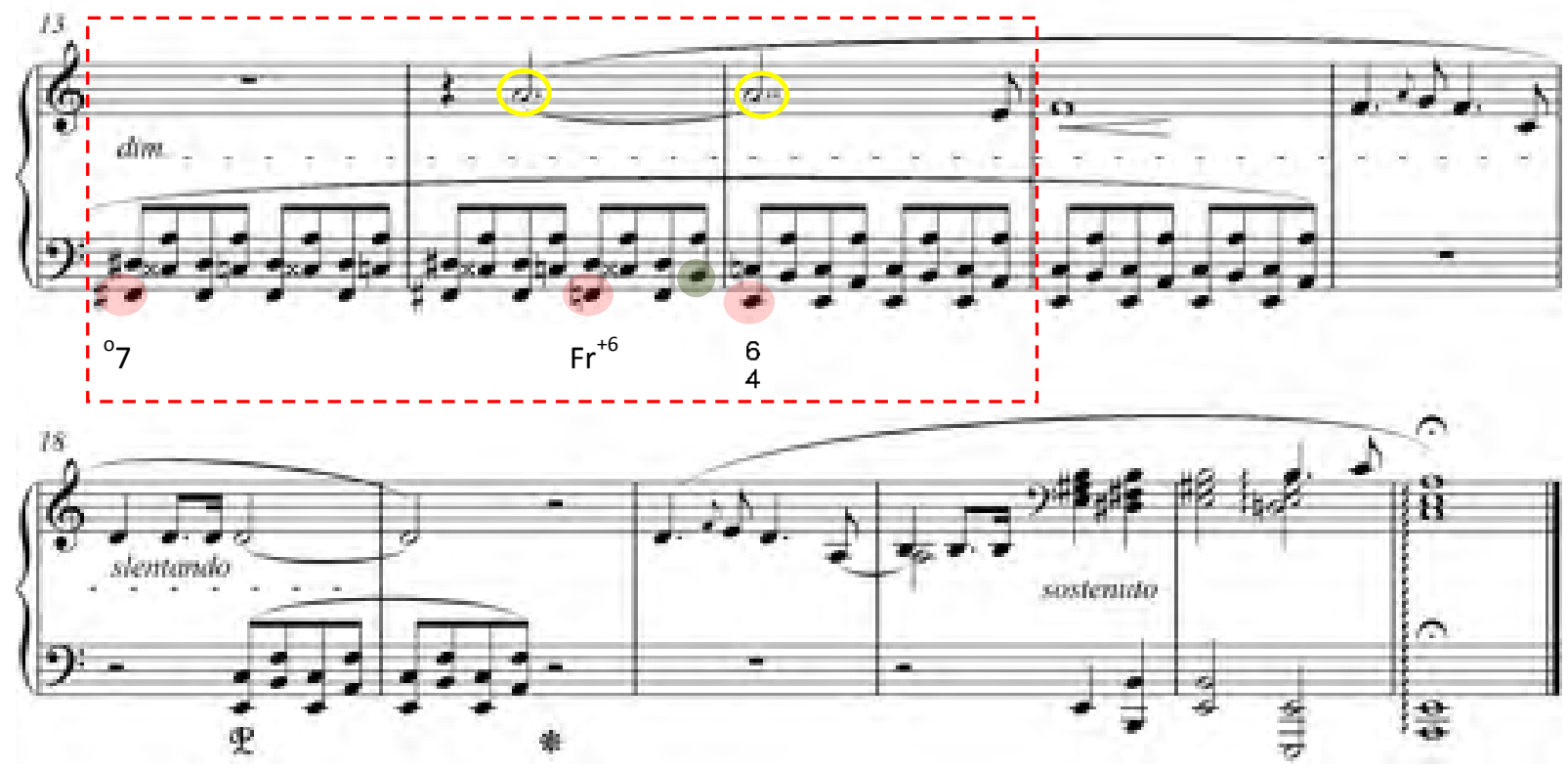

Similaridades entre os aspectos levantados neste tópico também podem ser encontradas em outras obras do compositor polonês, tais como a Mazurka Op. 68 no 4 e o Noturno Op. 27 no 1, como será destacado nos itens seguintes.

\section{2 - PASSAGENS NÃO TEMÁTICAS}

O segundo item da classificação proposta por Dittrich refere-se às passagens em que os modelos do Teufelsmühle ou omnibus são utilizados em partes não temáticas, tais como desenvolvimentos, transições e cadências de concertos. A autora observa sobre as recorrências em peças como fantasias ou gêneros aparentados e cita o Rondo em Lá menor (cf. Ex. 49) e a Fantasia em Dó maior de C. P. E. Bach, entre outros (DITTRICH, 2007, p. 117).

Dentro desta categoria, as estruturas do Teufelsmühle e omnibus na música de Chopin são encontradas em diferentes momentos formais, tais como introduções, transições, desenvolvimentos e codas. A seguir serão enumeradas e expostas algumas obras que possuem tais contextos, no entanto, cabe salientar que determinados exemplos irão receber uma atenção maior, em virtude de apresentarem também outros aspectos que compõem a linguagem musical do compositor polonês no que diz respeito às estruturas do Teufelsmühle e omnibus.

É comum que os modelos cromáticos assumam a função de passagens não temáticas e sejam empregados apenas parcialmente na introdução de uma peça, de forma que podem 
ser classificados como um fragmento, um prenúncio ou mesmo uma citação. Exemplos que ilustram o uso destas sequências cromáticas na parte introdutória de uma obra são observados do Rondo Op. 73, em que ocorre um prenúncio do omnibus (Cf. Ex. 59), e no segundo movimento do Segundo Concerto Op. 21, que apresenta uma citação do Teufelsmühle (Cf. Ex. 61).

No Prelúdio Op. 28 no 17 em LábM, um fragmento do Teufelsmühle ocorre apenas como um elemento de ligação entre as frases. A versão B nesta peça integra cinco acordes: germânica; menor com quarta e sexta; dominante com sétima no baixo; dominante com sétima; e uma alteração para um acorde maior com quarta e sexta, colocado no lugar do acorde menor (Ex. 86).

Exemplo 86 - Prelúdio Op. 28 no 17: comps. 52 - 57
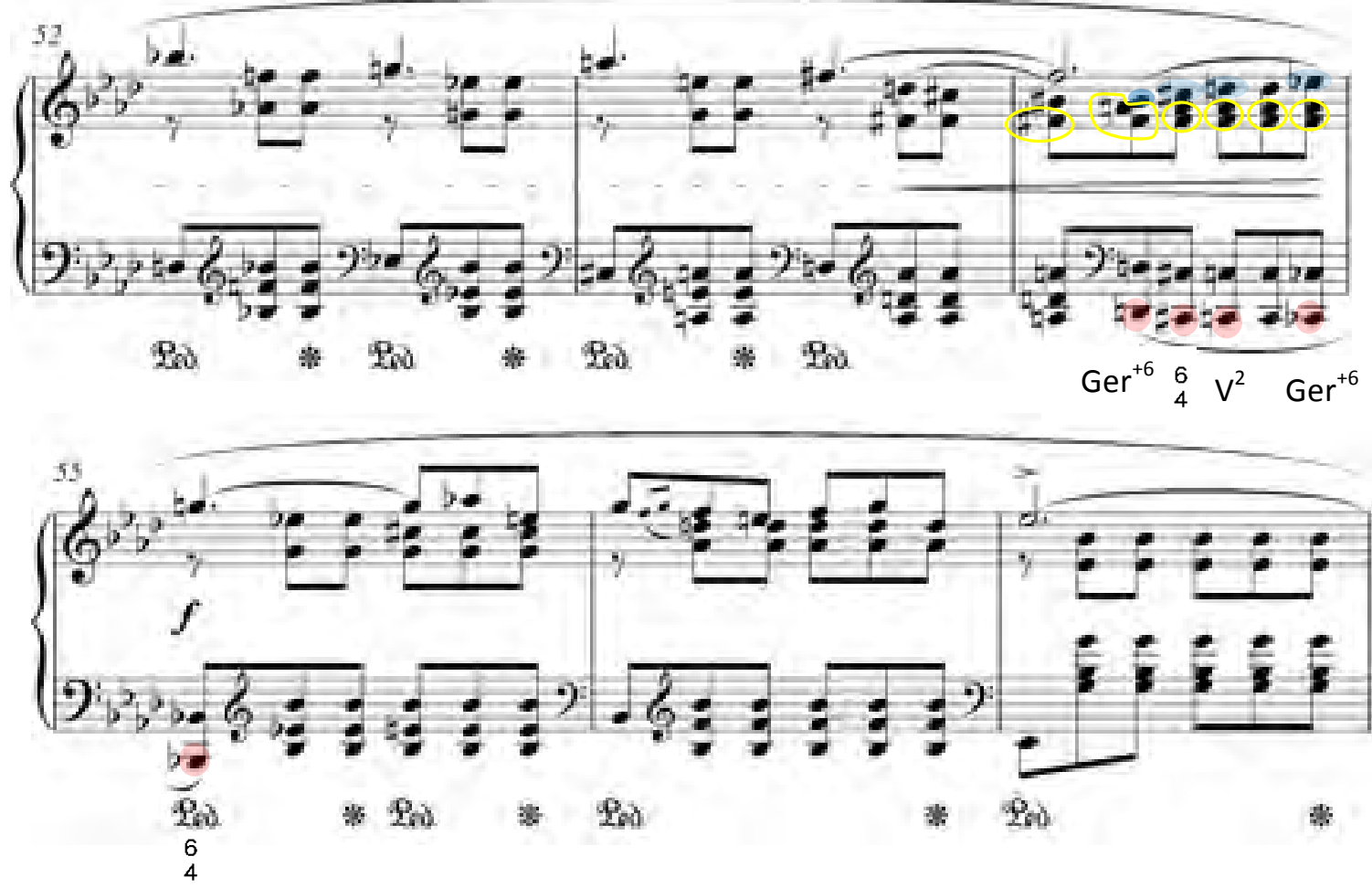

(M)

Redução: Teufelsmühle versão B com variante

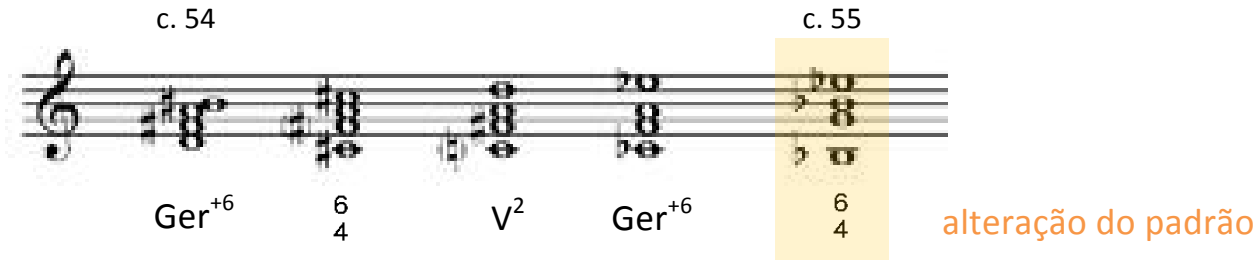

(M) 
Ainda neste prelúdio é possível observar que o movimento contrário cromático e simétrico ocorre nas vozes do baixo e soprano enquanto as notas Fá\# e La permanecem mantidas na voz interna. Outro aspecto a ser notado nesta passagem é a indicação de um crescendo que conduz a uma dinâmica forte no compasso 55.

Os exemplos a seguir irão ilustrar a forma diversificada com que o compositor explora este recurso, tanto do ponto de vista formal quanto estrutural.

No Noturno Op. 15 no 2 em Fá\# menor, estruturado na forma ABA, um fragmento do Teufelsmühle é identificado na transição (comps. 17 -24) para interligar as partes $A$ e $B$, que apresentam os andamentos Larghetto e Doppio movimento, respectivamente. A passagem dos compassos 18 - 21 contém a versão B com três acordes: menor com quarta e sexta, dominante com sétima no baixo e dominante com sétima em estado fundamental (Ex. 87).

Exemplo 87 - Noturno Op. 15 no 2: comps. 15 - 28
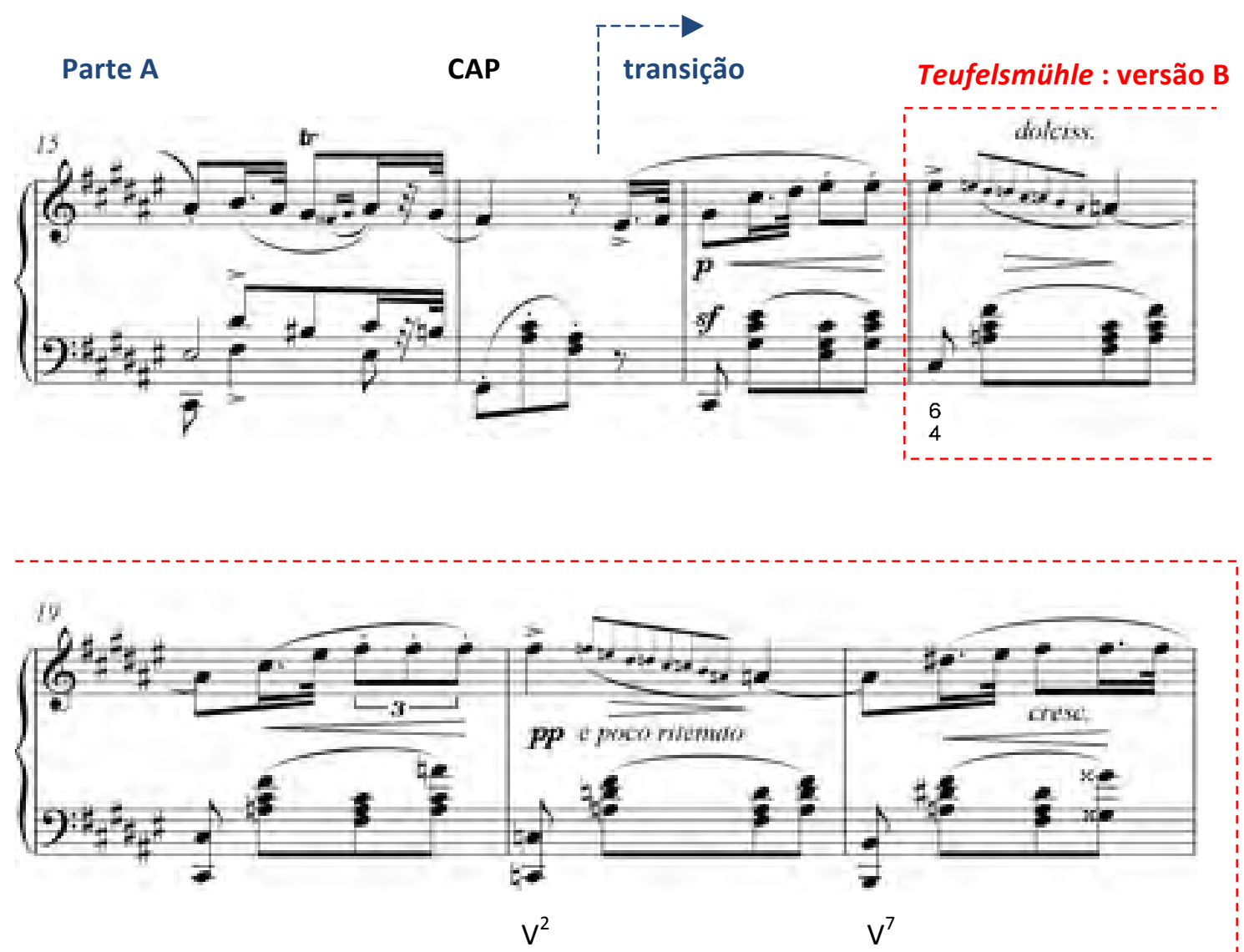


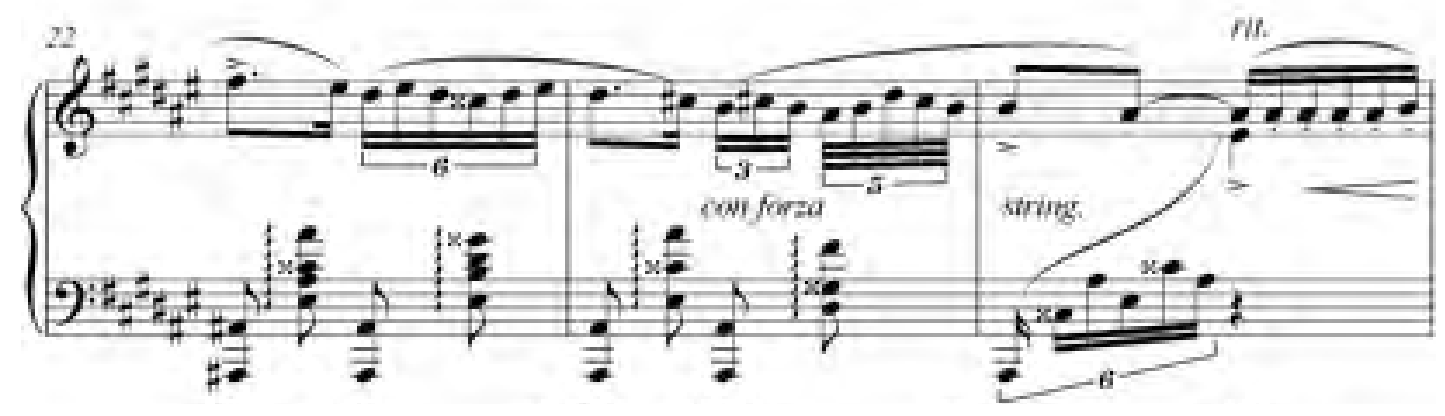

Parte B

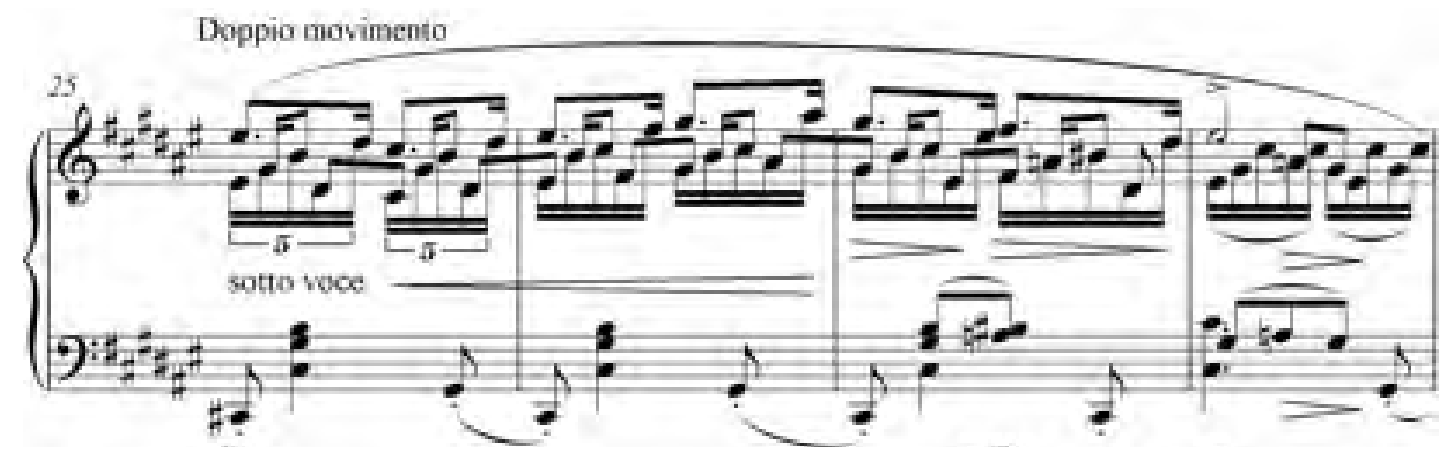

\section{Redução: Teufelsmühle versão B}

c. 18

c. 20

c. 21

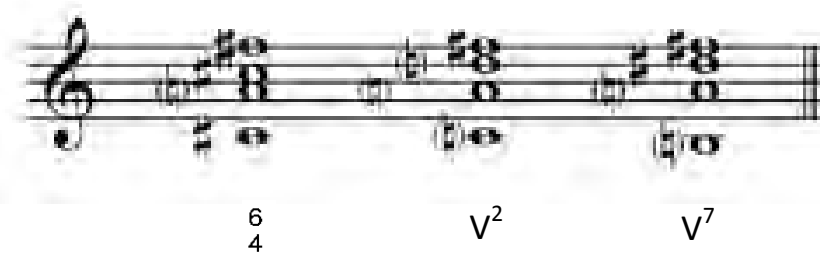

Observa-se no exemplo 87 que a linha da mão direita é enfatizada, no trecho inteiro, apenas com as duas notas que compõe o pedal da progressão cromática do Teufelsmühle (Lá e Fá\#). Além disso, ocorre um contraste de dinâmica significativo no compasso 20 , com a indicação de $p p$ súbito exatamente na dominante com sétima no baixo, tipologia usualmente escolhida por Chopin, seja como parte do Teufelsmühle ou de sua variante descrita no item 3. 3. 3, para gerar uma inflexão ou mesmo um efetivo destaque no discurso musical.

Um caso singular do emprego do Teufelsmühle encontra-se na Fantasia Op. 49, o que justifica uma exposição mais detalhada, que irá incluir a análise formal desta obra realizada por Carl Schachter (Ex. 88) em seu artigo "Chopin's Fantasy, Op. 49: the two-key scheme" (1991, p. 224). 
Exemplo 88 - Fantasia Op. 49: análise formal de Schachter

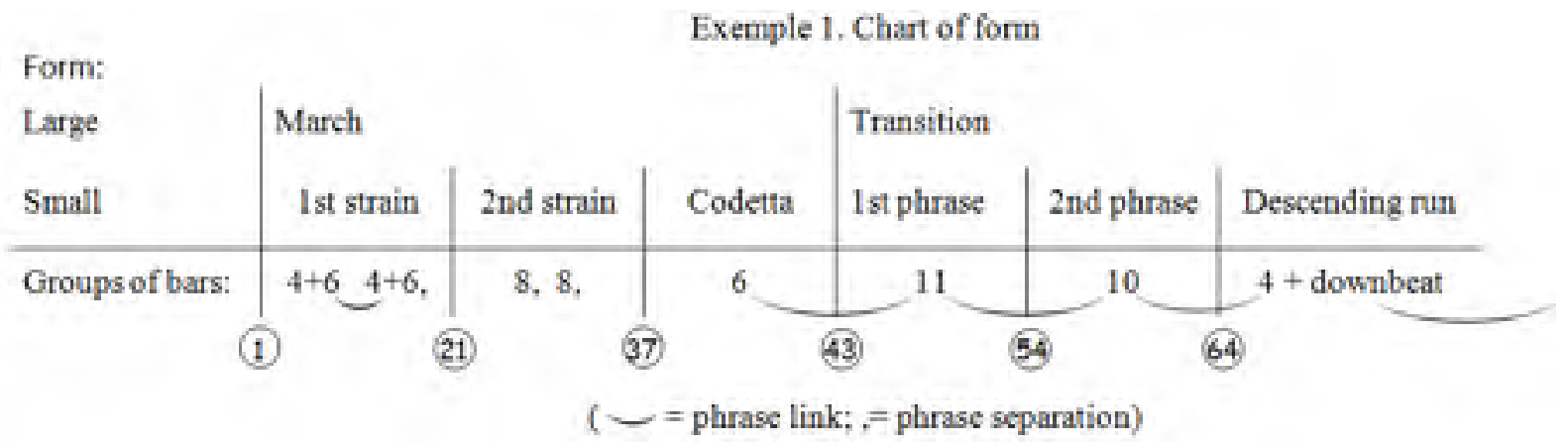

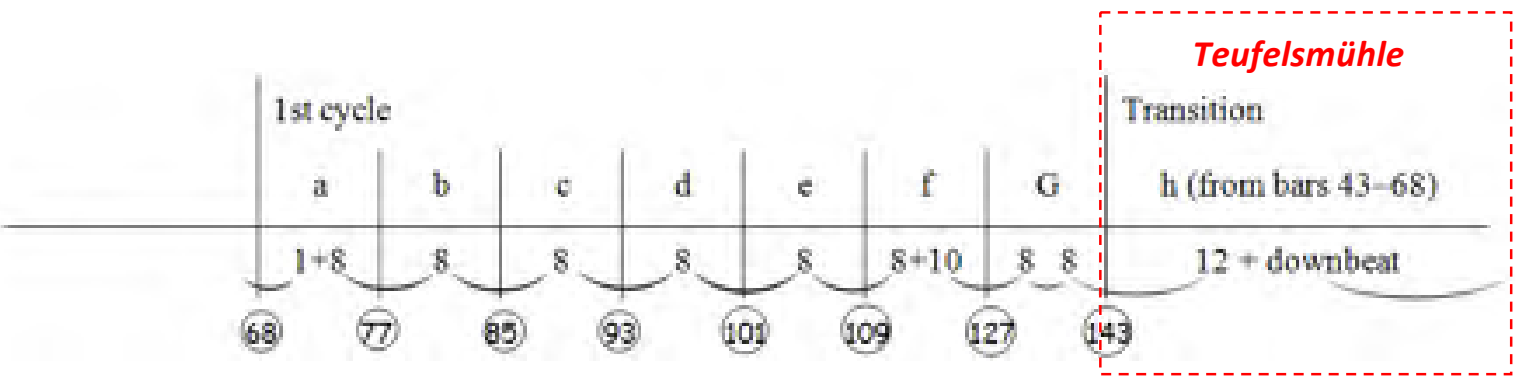

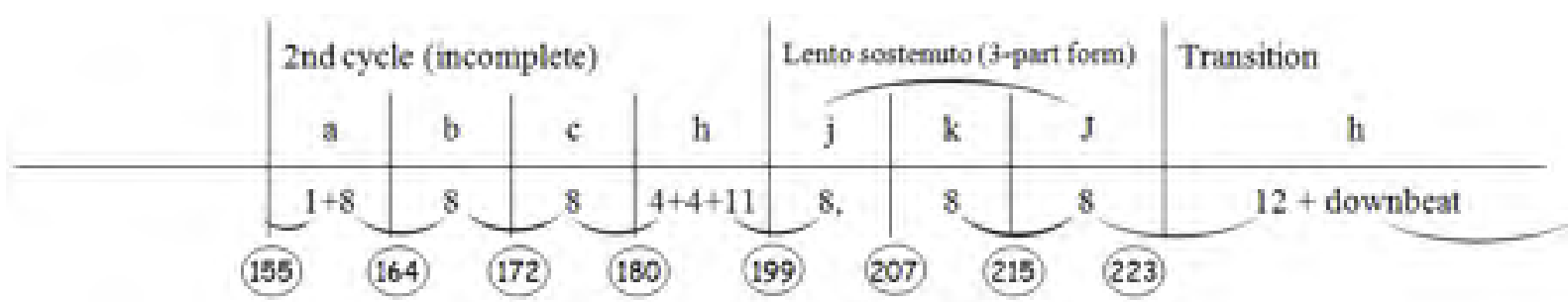

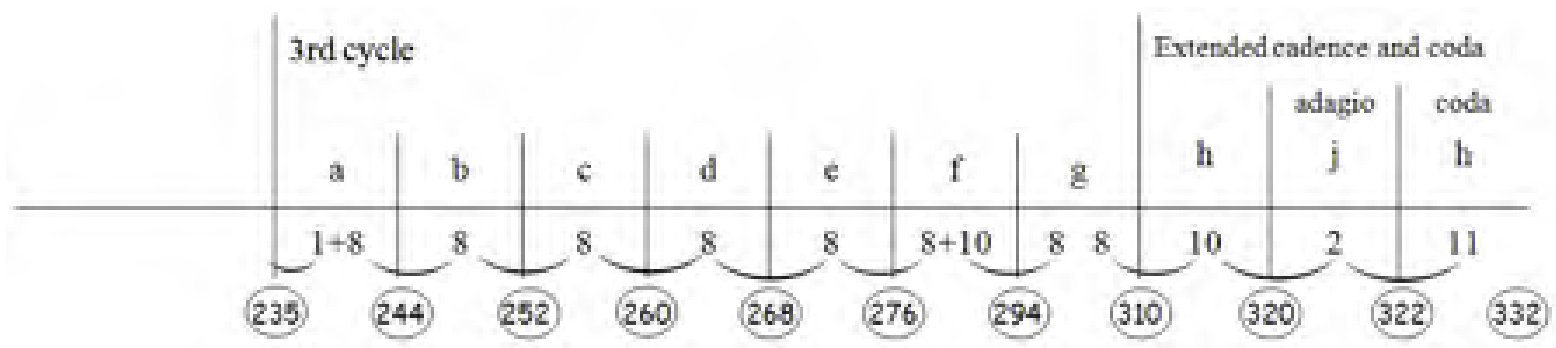

Embora o autor não identifique a presença do Teufelsmühle, a clareza de sua exposição no agrupamento dos elementos motívicos em unidades formais propicia uma visão geral da obra, de modo que complementa a argumentação desta pesquisa, que irá apontar e contextualizar a importância dos modelos cromáticos na passagem de transição entre o primeiro e o segundo ciclos. 
Segundo Schachter, o acorde de $V^{2}$ do compasso 143 nega a esperada resolução em Mib maior e gera dificuldades no entendimento dos vínculos harmônicos, que o autor resume da seguinte forma:

A função do acorde dissonante (compasso 143) que cria um "efeito deceptivo" não está imediatamente clara. Na verdade, somente quando atingimos o segundo ciclo nós vemos que ele resulta da inflexão cromática do ${ }^{6}{ }^{6}$ que apareceu no compasso 141 (1991, p. 243).

Na continuação de sua análise, Schachter expõe um gráfico com uma redução nos moldes Schenkerianos que abarca os compassos 143 - 155, de forma que é possível constatar que o autor interpreta a passagem do Teufelsmühle como um grande prolongamento do alV do tom de Mib maior (Ex. 89).

Exemplos 89 - Fantasia Op. 49: comps. 109 - 164, redução de Schachter (1991, p. 247)

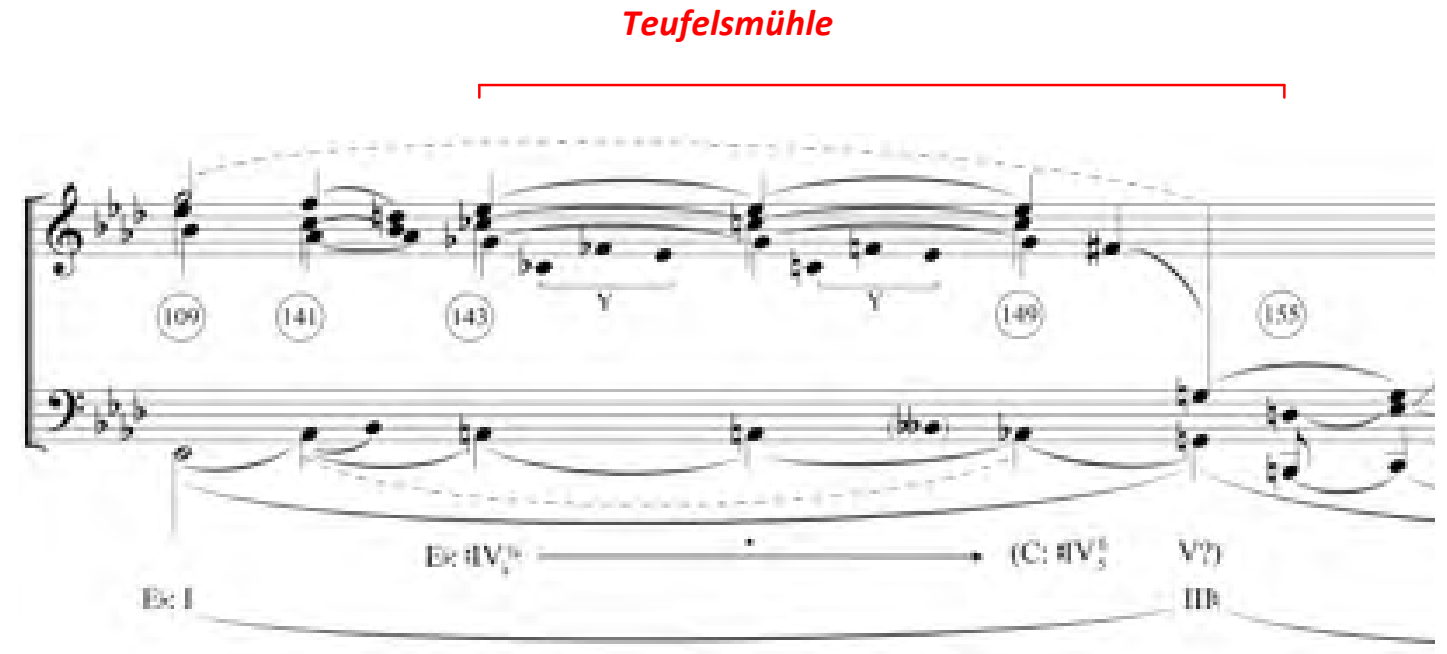

Talvez a busca por vínculos tonais que justifiquem a macro-estrutura da peça fez com que Schachter empregasse a reinterpretação enarmônica para explicar a passagem, na qual um acorde de Sib maior com sétima menor (comp. 142) dirige-se para outra dominante, o Si maior com sétima no baixo (comp. 143). A saída a qual o autor recorre permite que uma dominante, por meio de enarmonizações, seja reinterpretada como um acorde de sexta aumentada $\left(\operatorname{Ger}^{+6}\right)$. De tal forma, as notas da dominante Lá - Si - Ré\# - Fá\# do compasso 143 passam a ser assumidas na 
análise de Schachter como Lá - Dób - Mib - Solb, membros do acorde Ger ${ }^{+6}$, preparador da dominante de MibM.

Embora tal abordagem seja coerente aos seus propósitos, para esta pesquisa tornase indispensável esclarecer que, neste caso, não se trata apenas de subordinar o caráter desta transição em prol de um vínculo com áreas tonais. É o detalhe, fruto da condução de vozes, da ruptura com a expectativa cadencial, a promoção da ambigüidade, o redirecionamento harmônico, dentre outros fatores (Cf. Ex. 71), que enriquecem a linguagem de Chopin.

Neste sentido, o posicionamento assumido por esta pesquisa está também traduzido nas palavras do americano E. T. Cone:

[...] nosso desejo atual de demonstrar unidade tonal sempre que possível nos leva a descrever a estrutura como um prolongamento de uma única harmonia, cuja função não se deve estar em dúvida. Como resultado, nós não ouvimos a música como eu acredito que ela foi planejada para ser ouvida. É por isso que eu tenho recorrido ao que chamo de "análise intencional", que procura evidenciar, tanto quanto possível, como o compositor gostaria que ouvíssemos sua música. Eu sugiro que Chopin estava sendo deliberadamente ambíguo aqui [referindo-se a passagem dos compassos $1-8$ da Quarta Balada Op. 52] e que uma análise convincente desta passagem deve revelar essa intenção (2006, p. 141).

A apresentação dos posicionamentos de Schachter e Cone suscitam reflexões sobre a abrangência latente que uma obra musical permite em termos de abordagens analíticas. Desta forma, a explanação que será feita a seguir é apenas uma maneira de interpretar a passagem dos compassos 143 - 155 da Fantasia Op. 49, na qual será considerado o modelo do Teufelsmühle como único elemento gerador.

De forma singular, toda a extensão do trecho é formada pelas versões $A$ e $B$ do Teufelsmühle e corresponde à transição entre a marcha em Mib maior e o tema em Dó menor que inicia no compasso 155. Observa-se também que a passagem emprega uma figuração de arpejos em um caráter aflito e instável, radicalmente oposto à estabilidade harmônica obtida na marcha triunfal e com júbilo precedente ${ }^{10}$ (Ex. 90).

\footnotetext{
${ }^{10}$ No quadro de Schachter a marcha em MibM corresponde à letra ' $g$ ' do primeiro ciclo (comps. 127 - 143) enquanto que o tema em Dó menor à letra 'a' do segundo ciclo (comps. 155 - 164)
} 
Exemplo 90 - Fantasia Op. 49, comps. 136 - 155

Marcha em Mib maior

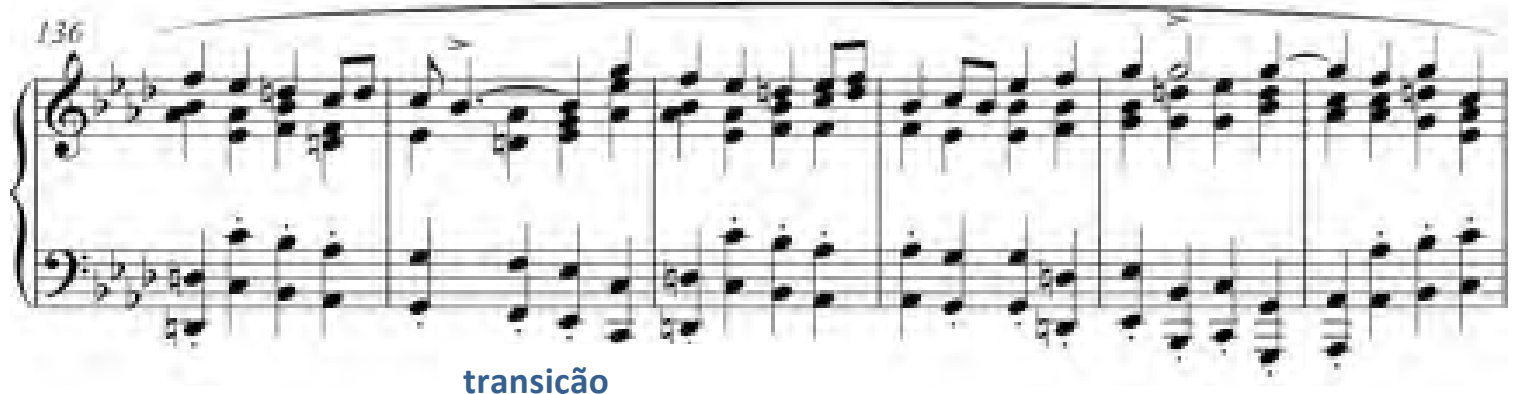

variante de Chopin

Teufelsmühle
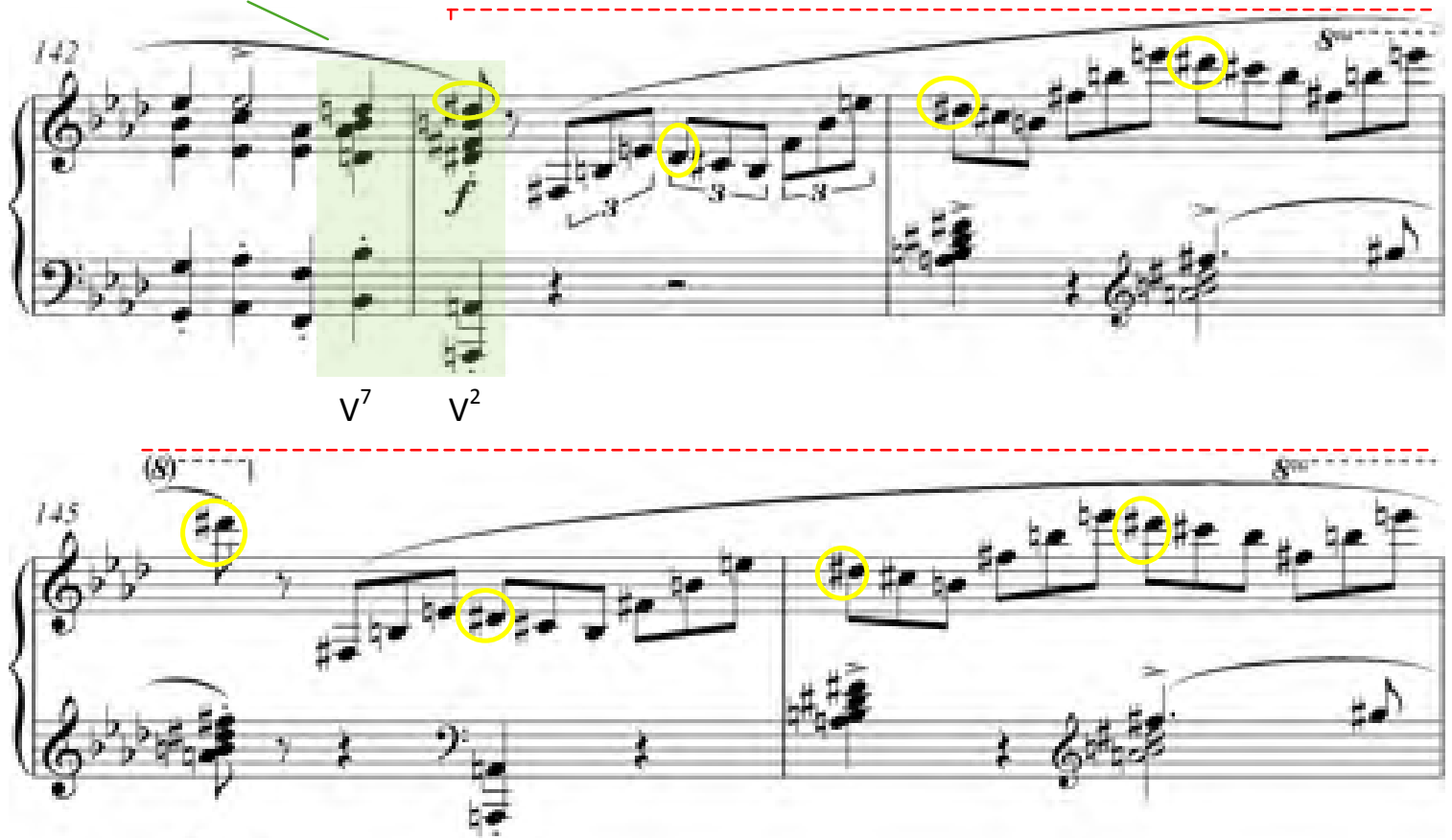

$(8)-\cdots$
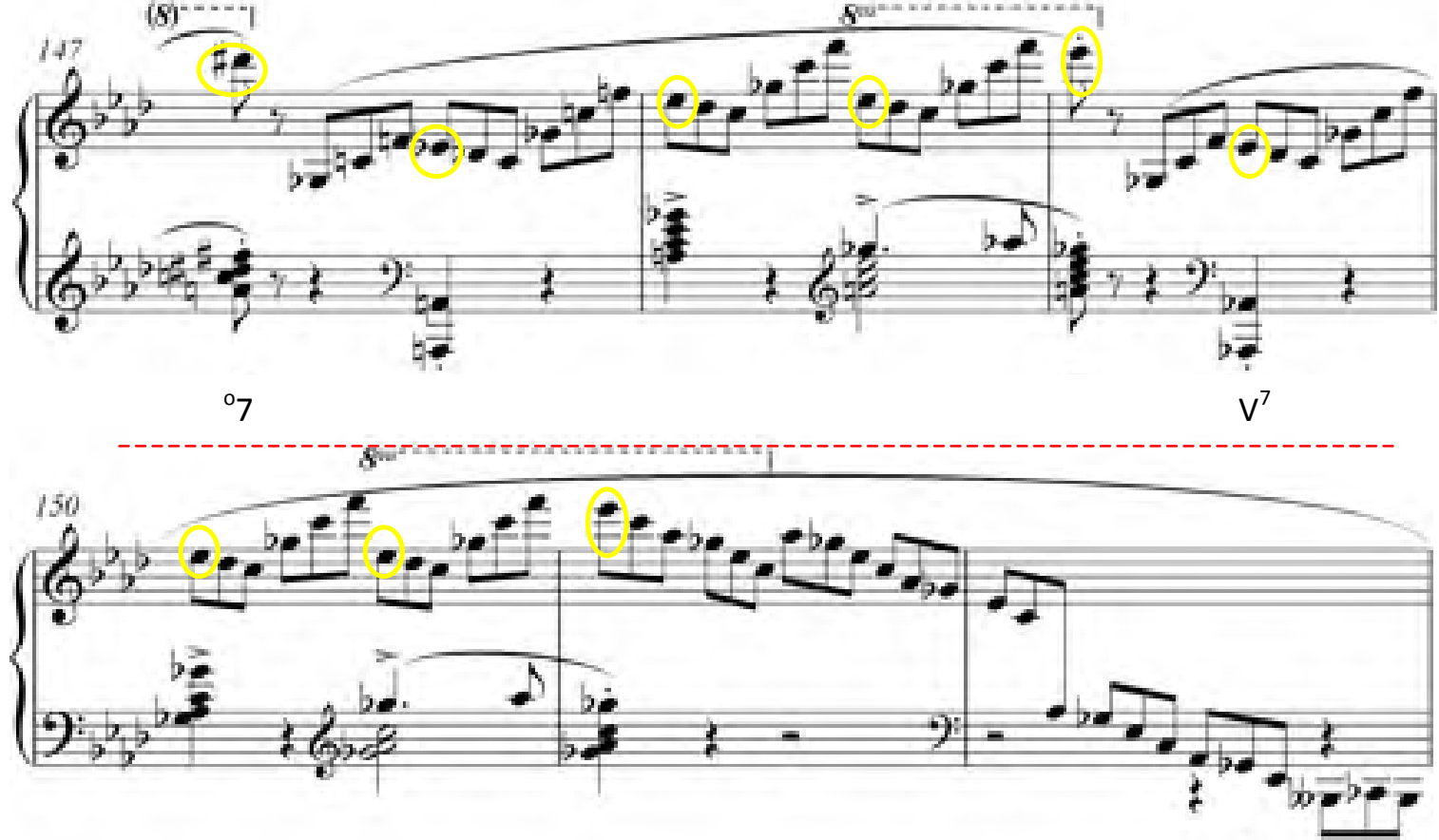


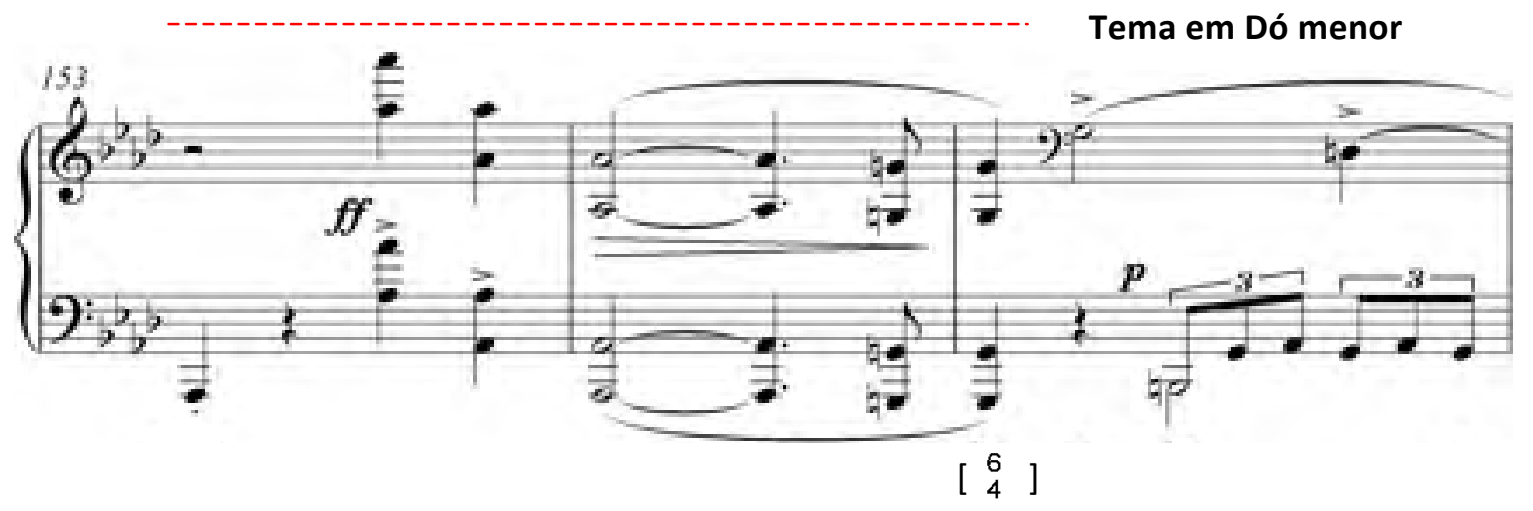

Introduzido pela variante de Chopin nos compassos 142 e 143, o Teufelsmühle configura-se a partir do primeiro tempo do compasso 143 , de forma que está estendido por doze compassos, incluindo o tempo forte do compasso 155, e com função modulatória. A redução apresentada abaixo demonstra as tipologias e a condução de vozes empregada nesta sequência cromática em uma comparação com o modelo original de Vogler (Ex. 91).

Exemplo 91 - Reduções: Fantasia Op. 49, comps. 142 - 155 e modelo de Vogler

a) Modelo de Vogler

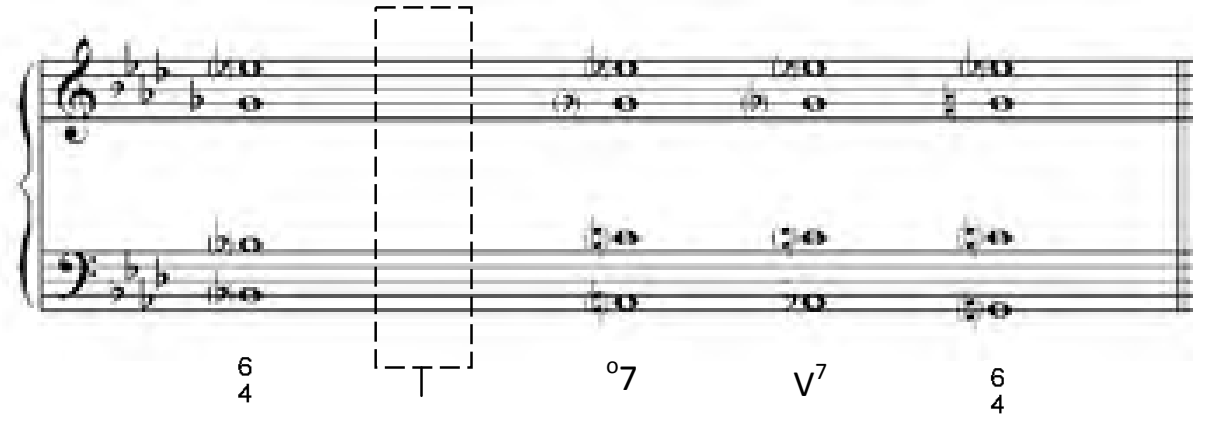

variante de Chopin

c. 142

c. 143

c. 147

c. 149

c. 155

b) Fantasia Op. 49
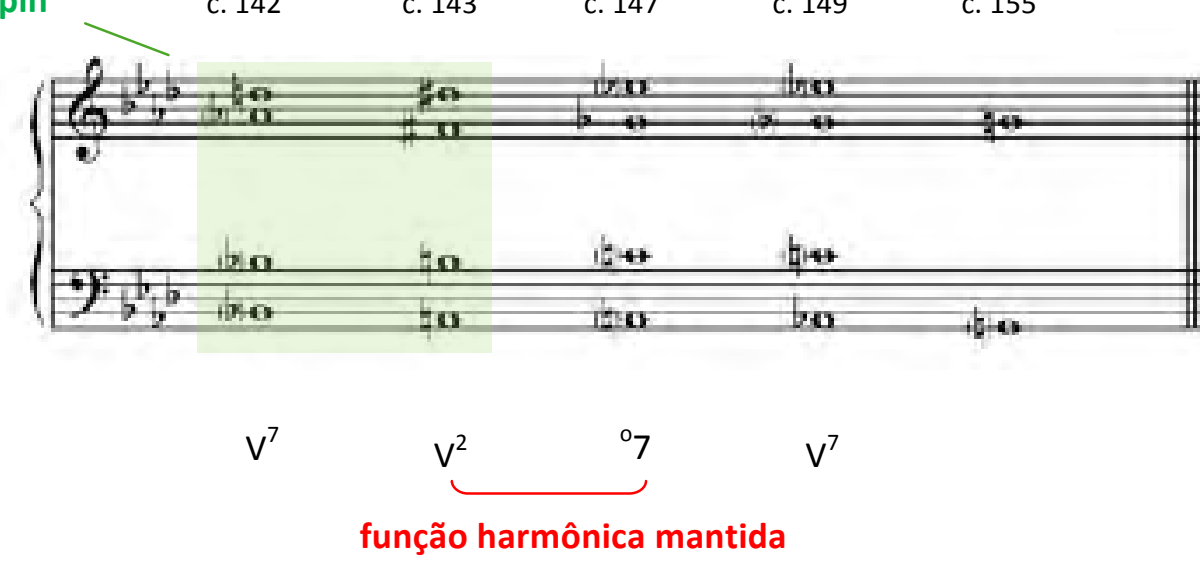
O elaborado emprego do Teufelsmühle na fantasia já pode ser constatado na abertura do trecho, que envolve o uso da variante de Chopin. Logo em seguida é possível visualizar no exemplo $91 \mathrm{~b}$ que o acorde diminuto do compasso 147 constitui um desdobramento da $\mathrm{V}^{2}$ anterior, ou seja, embora ocorra uma transformação para a tipologia do diminuto, a função harmônica é mantida. Desta forma, em três momentos distintos Chopin faz uso das seguintes alterações do modelo do Teufelsmühle: a substituição do acorde de Mib menor com quarta e sexta (comp. 142) pela $V^{7}$; a inclusão do acorde ${ }^{\circ} 7$ do compasso 147 como um desdobramento do acorde de $\mathrm{V}^{2}$ do compasso 143; e a substituição do acorde menor com quarta e sexta do compasso 155 apenas pela fundamental da dominante.

Por fim, uma observação da condução de vozes do exemplo 91b permite identificar que uma vez mais Chopin distribui a nota do pedal (Ré\#/Mib) na mão direita, de modo que são enfatizadas em tempo forte por toda a passagem, como assinalado em amarelo também no exemplo 90.

A seguir, uma análise da Mazurka Op. 68 no 4 ilustra o uso do Teufelsmühle (comps. 37 -40) no final da parte $B$, como transição que conduz à volta do tema inicial da parte $A$ (Ex. 92). A harmonização do baixo cromático descendente nesta passagem apresenta dois fragmentos do Teufelsmühle em sequência, com troca do diminuto gerador e substituição de acorde.

\section{Exemplo 92 - Mazurka Op. 68 no 4}

\section{a) Comps. 28 - 40}

Parte B

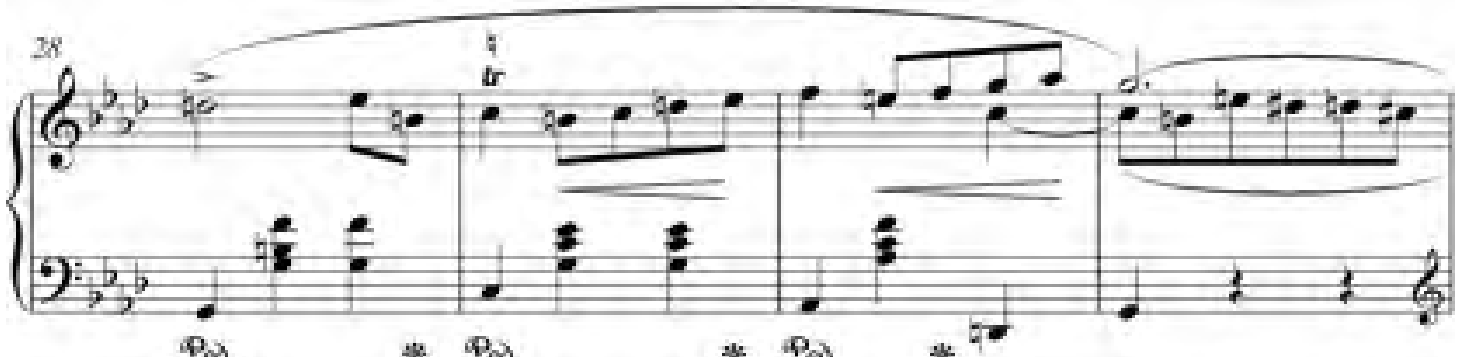

90

Pa

20

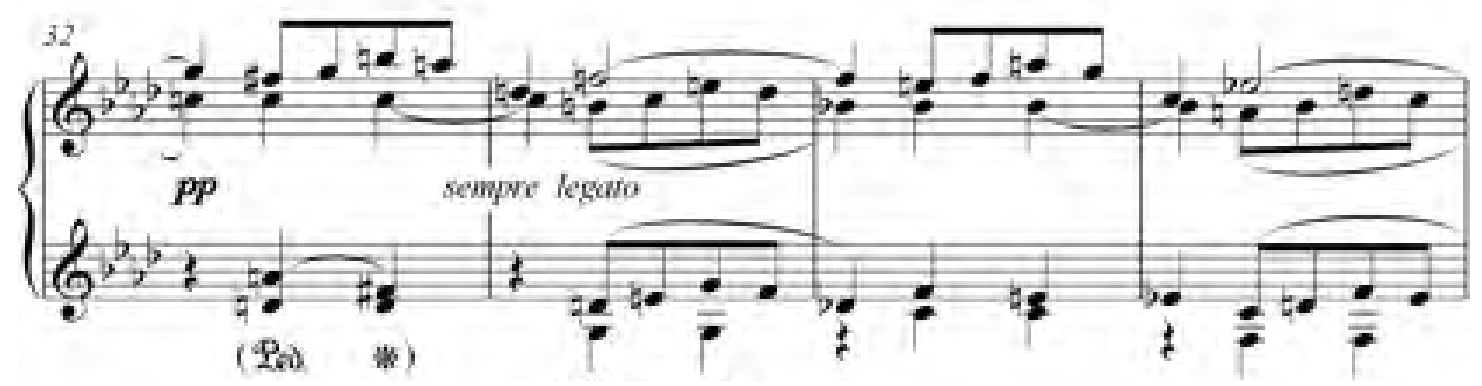


fragmento 1 diminuto gerador: Dó\# fragmento 2

diminuto gerador: $\mathrm{Si}^{\circ}$

bordadura

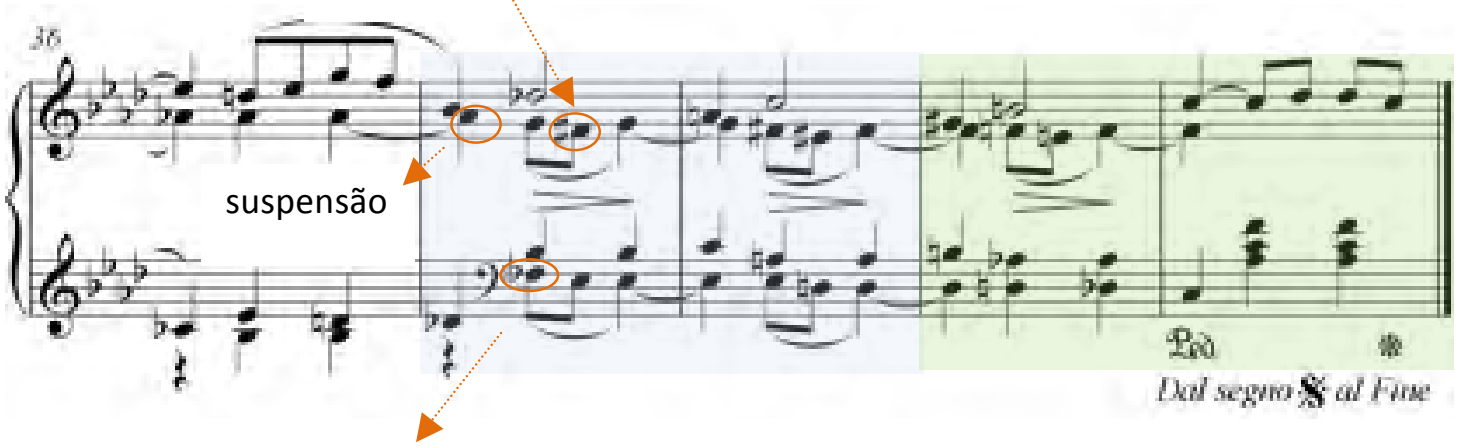

apojatura

$\mathrm{V}^{7}$

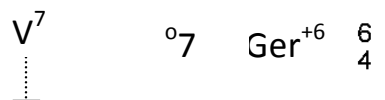

substituição de acorde

b) Comps. 1 - 5

Parte A

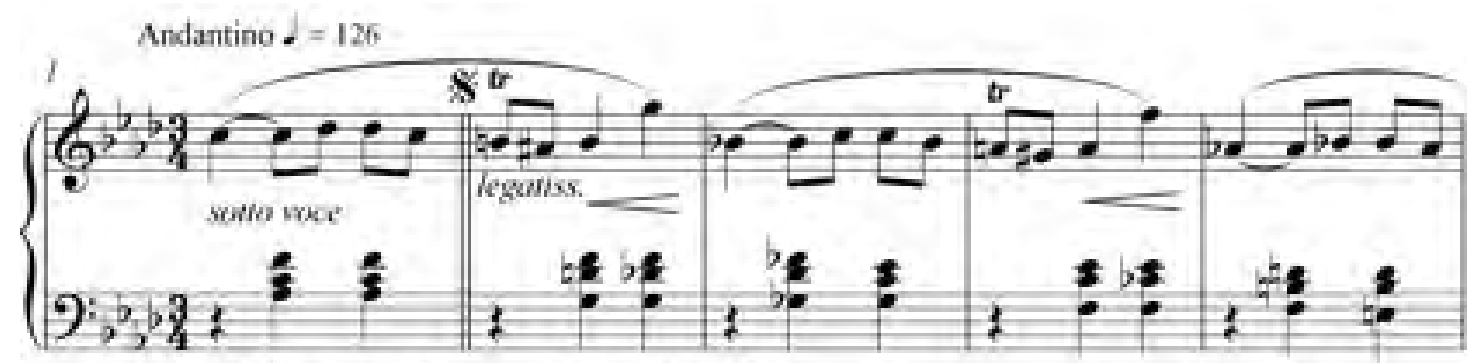

O primeiro fragmento, a partir do diminuto gerador Dó\# (comps. 37 - 38), sugere uma apresentação parcial da versão $A$ com variante na seguinte disposição: $V^{7}$ e $V^{7}$, de modo que este último acorde está no lugar do menor com quarta sexta (Ex. 93a). A conexão entre o primeiro e o segundo fragmento é feita por meio da manutenção da nota Ré natural no baixo, momento em que ocorre a troca de tipologias e do diminuto gerador $\left(\mathrm{Si}^{\circ}\right)$. Desta forma, o segundo fragmento, também constituído pela versão $\mathrm{A}$ (comps. 39 - 40), apresenta três acordes exatamente como o modelo original: ${ }^{\circ} 7$, $\mathrm{V}^{7} / \mathrm{Ger}^{+6}$ e 6-4 (Ex. 93b). 
a) Versão $A$

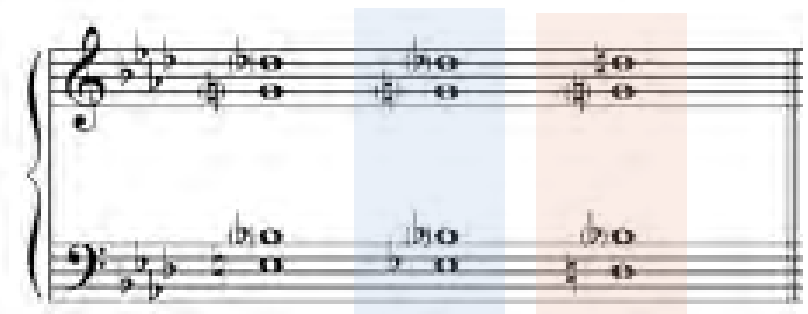

${ }^{\circ} 7 \quad \mathrm{~V}^{7} / \mathrm{Ger}^{+6} \quad 46$
Mazurka: fragmento 1

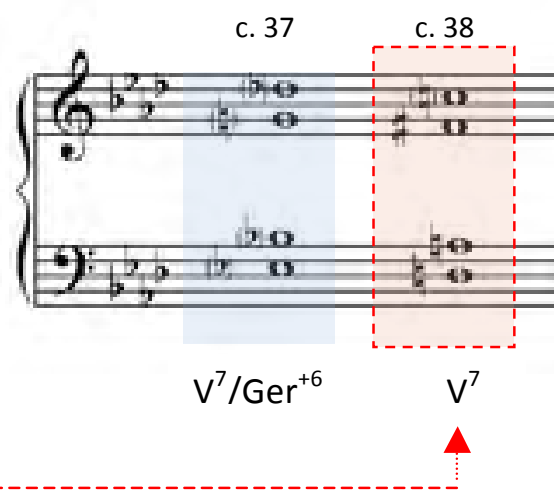

b) Comps. $37-40$
c. 37
c. 38
c. 39
c. 40

troca de tipologias

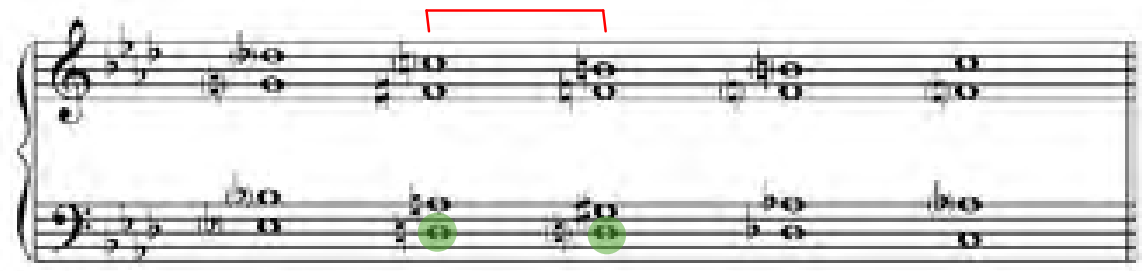

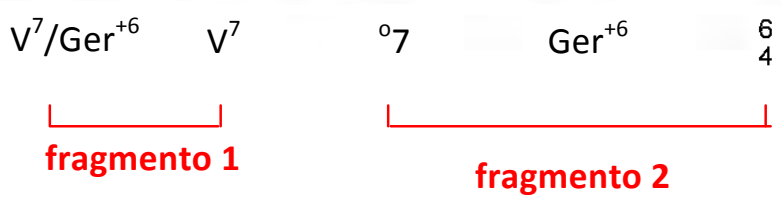

Vale notar que nesta passagem as notas do pedal encontram-se dispostas nas vozes internas enquanto o cromatismo é realizado nas vozes extremas. Entretanto, o fato do primeiro fragmento apresentar a substituição do acorde menor com quarta e sexta dificulta a identificação de Sol e Sib como notas do pedal. Já no segundo fragmento, a transposição para outro diminuto gerador implica, naturalmente, em outras notas mantidas em relação de terça menor, Fá e Láb.

No caso desta mazurka, a inserção dos modelos do Teufelsmühle em um tempo andantino, tonalidade menor e com o baixo cromático descendente incita uma possível

\footnotetext{
${ }^{11}$ As quintas paralelas geradas entre baixo e tenor no encadeamento do $\mathrm{V} 7 / \mathrm{Ger}^{+6}$ para $\mathrm{V}^{7}$ do fragmento 1 são inevitáveis e previstas nas regras de condução de vozes, cf. os tratados de Harmonia de Schoenberg (1999, p. 353) e Piston (1987, p. 424).
} 
associação com o contexto de lamento, incerteza e morte, exposto no primeiro item deste capítulo ${ }^{12}$.

O emprego do Teufelsmühle e/ou do omnibus em passagens não temáticas foi observado, no decorrer desta pesquisa, como a maneira mais usual com que Chopin faz uso destas sequências cromáticas. Exemplos ocorrem também em desenvolvimentos de sonatas, tais como nos movimentos iniciais da Primeira Sonata (comps. 92 - 98) e da Terceira Sonata (comps. $103-110)$.

\section{3 - CONTRASTE PARA PREPARAÇÃO DE PONTO CULMINANTE}

O reconhecimento do uso do Teufelsmühle no ponto culminante de uma obra já fora destacado por Seidel na coda do primeiro movimento da Segunda Sinfonia de Beethoven (SEIDEL, 1981, p. 287). Em The omnibus Idea Yellin também chama atenção para contextos vinculados ao clímax da peça, como na Sexta Sinfonia de Tschaikovsky (Cf. Ex. 47). No que diz respeito aos exemplos expostos pela pesquisadora alemã, destacam-se o Requiem Op. 89 de Dvorák e a Quinta Sinfonia de Bruckner (DITTRICH, 2007, p. 117 -119).

O emprego dos modelos cromáticos em passagens com grandes intensificações ocorre em gêneros significativos da obra de Chopin, tais como noturnos e baladas. Duas importantes obras, expostas por Yellin, são a Segunda Balada e o Noturno Op. 27 no 2, em que o autor associa o uso do omnibus ao ponto culminante e comenta, de forma crítica, sobre uma tendência geral em classificar os respectivos trechos apenas como um "mero cromatismo" em função de apresentarem "figurações complexas, às vezes com grande velocidade" (YELLIN, 1998, p. 52).

Outra ocorrência do Teufelsmühle é observada na coda da Primeira Balada (comps. 230 - 233), com uma indicação de crescendo para atingir o clímax em ff no compasso 238, de forma análoga à Segunda Balada comentada por Yellin, que também está inserida neste mesmo momento formal ${ }^{13}$.

Agora, alguns exemplos expostos no decorrer desta dissertação podem ser retomados para que se possa constatar o emprego dos padrões cromáticos vinculados a intensificação e dramaticidade do discurso musical. No Estudo Op. 10 no 9 (Ex. 23), a versão

\footnotetext{
${ }^{12}$ Vale lembrar que esta mazurka fora a última obra composta por Chopin, dois dias antes de sua morte.

${ }^{13}$ Yellin também expõe a Primeira Balada em seu livro (1998, p. 92), mas trata-se de outro trecho (comps. 258 - 260), que diz respeito às escalas cromáticas em movimento contrário no final da coda e que o autor relaciona à idéia omnibus, mas precisamente à base contrapontística da inversão simétrica.
} 
A do Teufelsmühle faz parte de um contexto com indicações de crescendo, sempre piu stretto e piu forte, accelerando e que culmina no $f f$ do compasso 28 . Nos prelúdios $O p .28$ no 8 e Op. 28 no 9 os modelos do Teufelsmühle também são empregados em passagens vinculadas ao ponto culminante da peça, conferir exemplos 58 e 65, respectivamente.

Com a finalidade de explorar o uso diversificado que Chopin fez deste recurso, a seguir serão realizadas exposições detalhadas dos dois noturnos que compõem o $O p$. 27 , visto a abrangência que os modelos cromáticos assumem no contexto desta obra.

Dois significativos aspectos resguardam, por assim dizer, a unidade entre as duas peças: a tonalidade, que apresenta um vínculo por mistura de modos - Op. 27 no 1 em Dó\#m/Rébm e o Op. 27 no 2 em RébM - e o tipo de escrita, com figuração em forma de grandes arpejos na mão esquerda (Ex. 94), nos quais se observam distâncias maiores que as usuais entre suas notas (EIGELDINGER, 1991, p. 38).

Exemplo 94 - Noturnos Op. 27 no 1 e 2: figuração da mão esquerda

a) $0 p .27$ no 1

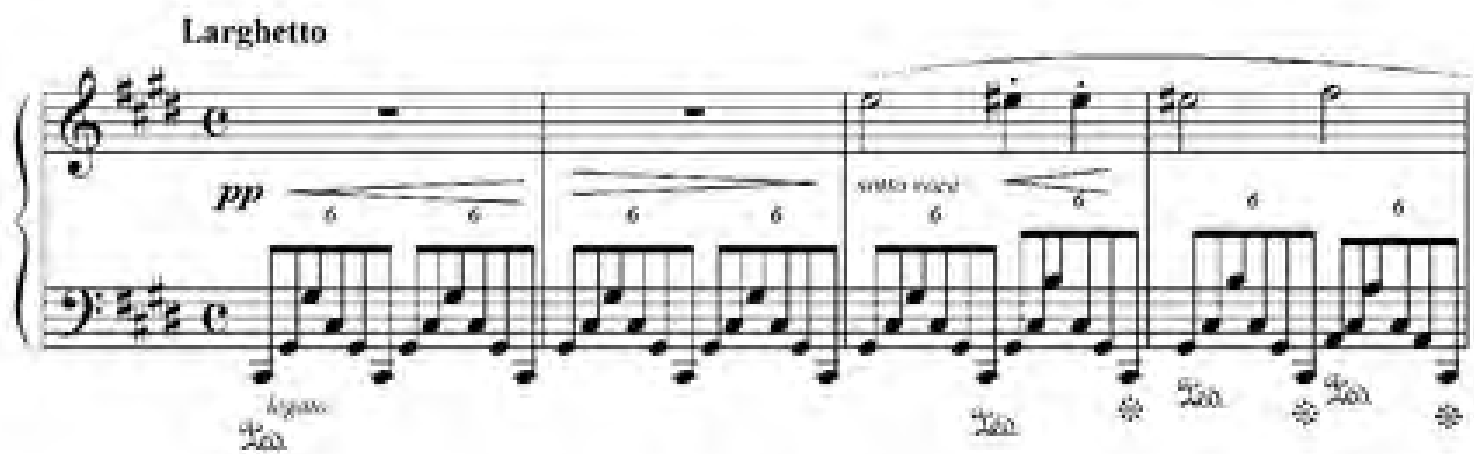

b) Op. 27 no 2

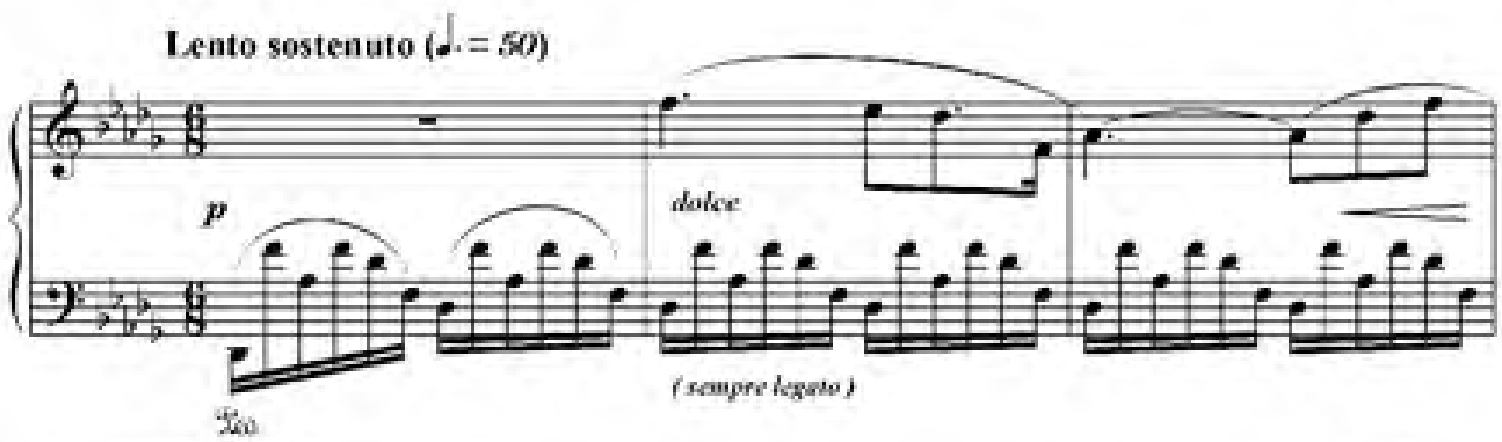


Estruturado na forma ABA, o Noturno Op. 27 no 1 ilustra o emprego do Teufelsmühle na parte B (Piu mosso), em uma passagem de transição que precede a volta do tema inicial no compasso 84 (Larghetto).

Os compassos 78 - 81 antecedem a entrada da versão A e empregam apenas dois acordes diminutos: $\mathrm{Si}^{07}$ e $\mathrm{Fá}^{07}{ }^{07}$, em suas diferentes formas de apresentação enarmônica. Neste trecho Chopin faz uso do vínculo com o segundo modo de transposição limitada de Messiaen ${ }^{14}$, com o emprego de acordes de sétima diminuta e da escala octatônica (Ex. 95).

Exemplo 95 - Noturno Op. 27 no 1, comps. 78 - 81

a) Comps. 78 - 79:
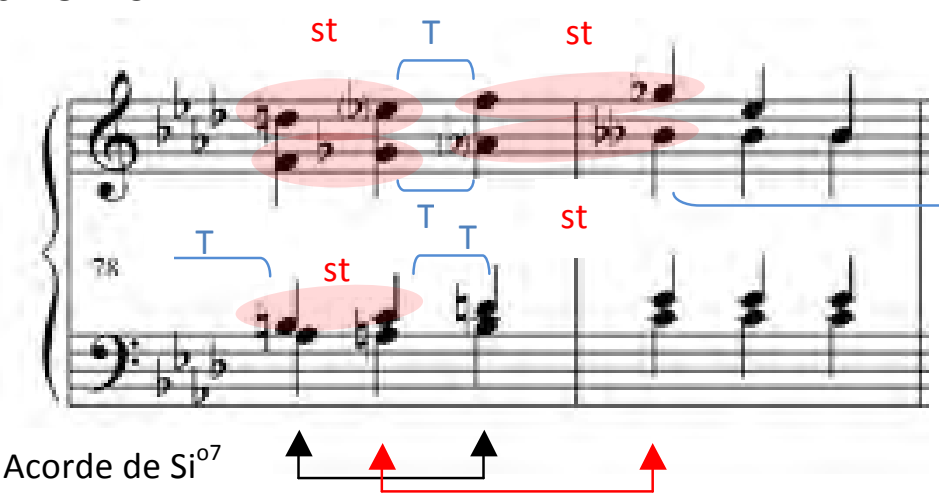

Acorde de Fá\# ${ }^{07}$

Notas dispostas linearmente: escala octatônica:

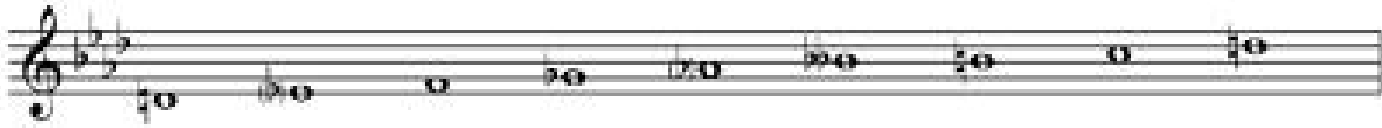

b) Comps. 80 - 81:

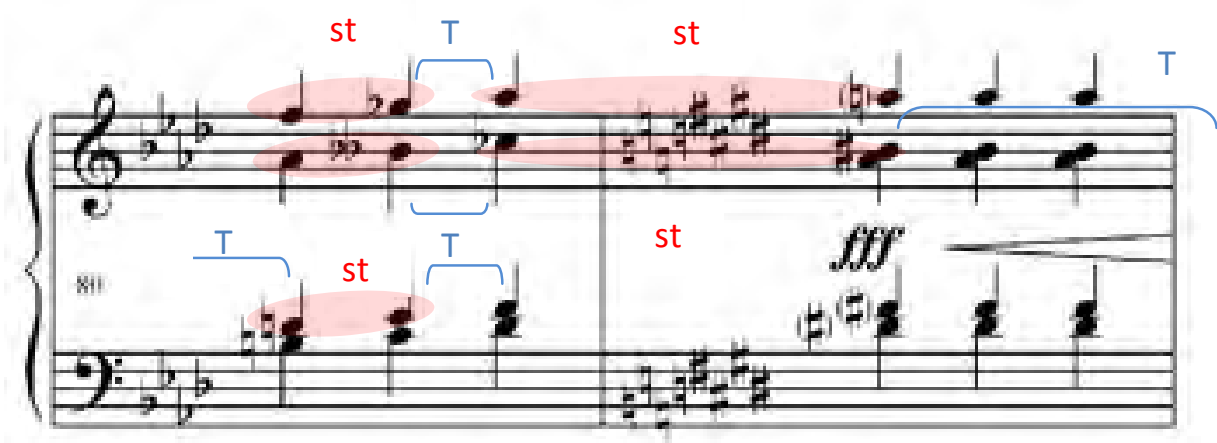

${ }^{14}$ Cf. item 1.3 desta dissertação. 
Notas dispostas linearmente: escala octatônica:

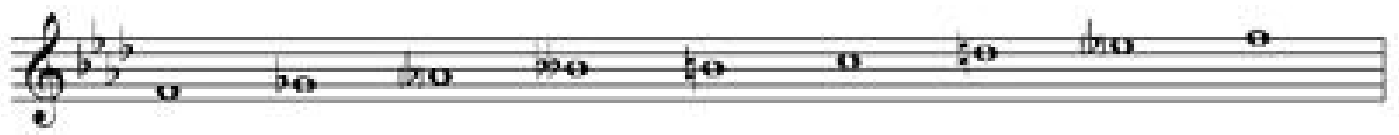

A partir do diminuto gerador Dó, um fragmento com quatro tipologias é apresentado nos compassos 81 - 83. O baixo cromático descendente deste noturno, com a omissão de um acorde, é harmonizado da seguinte maneira: diminuto, menor com quarta e sexta, diminuto e dominante com sétima em primeira inversão. A omissão do acorde Ré $^{7}$ ocorre entre o primeiro diminuto e o acorde com quarta e sexta. Além disso, vale destacar que o último acorde da sequência - Sol\# maior em primeira inversão com sétima - é característico apenas do padrão do omnibus (Ex. 96).

\section{Exemplo 96 - Noturno Op. 27 no 1: comps. 77 - 83}

octatônica

Teufelsmühle

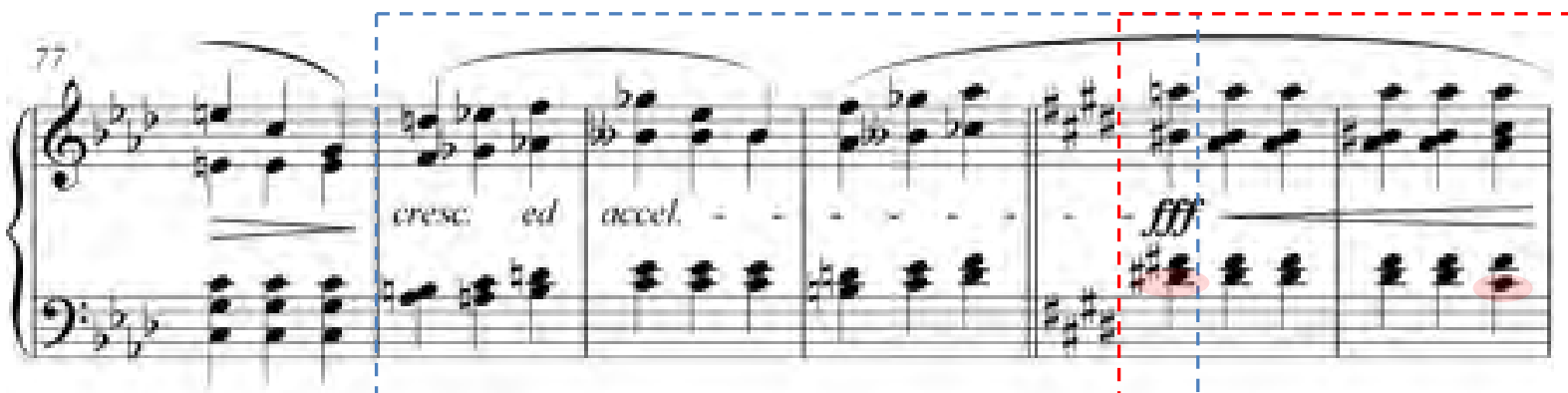

${ }^{\circ} 7$

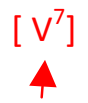

acorde omitido

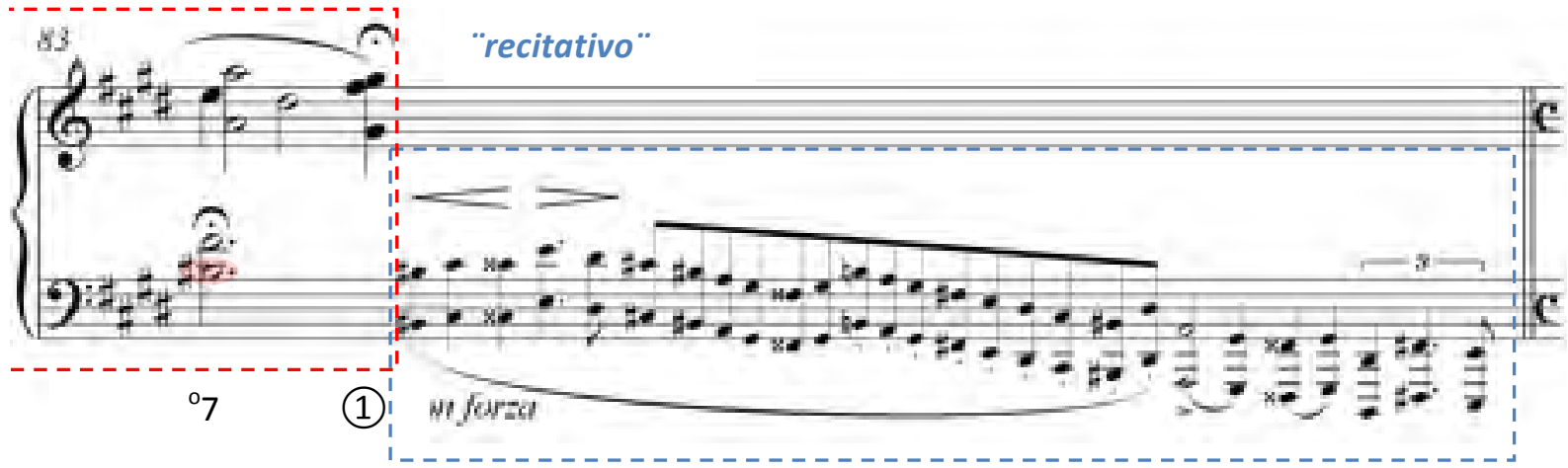




\section{Redução:}

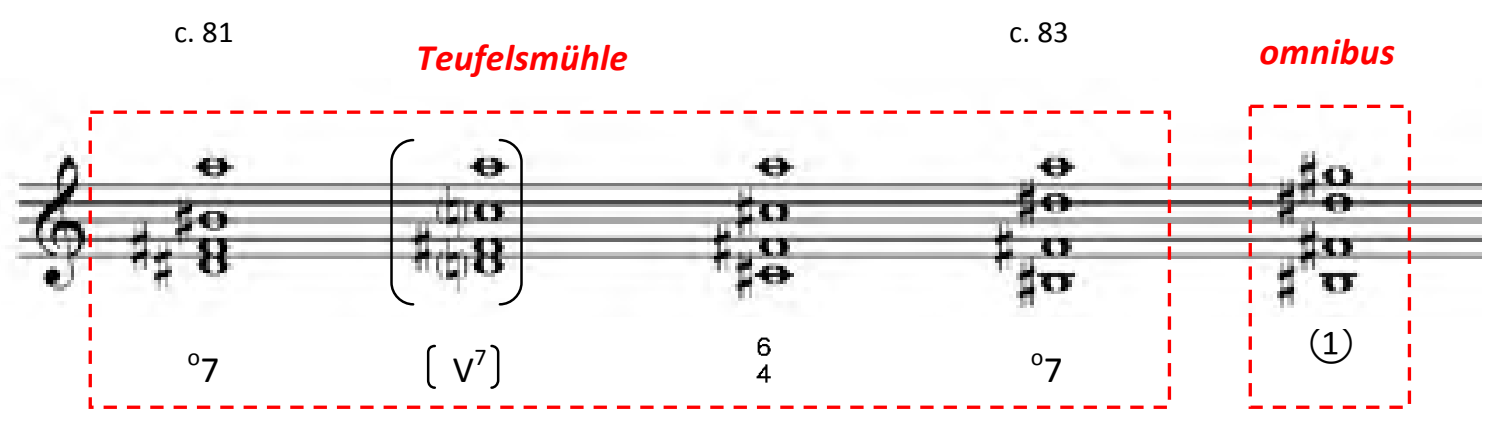

Uma observação da condução de vozes nesta peça permite constatar que novamente uma nota do pedal (Lá) está disposta na região mais aguda da mão direita no decorrer deste padrão cromático.

Em suma, o Teufelsmühle/omnibus se configura como um elemento de ligação que encerra a parte $B$, numa passagem em fff com crescendo em direção à fermata e que anuncia o recitativo do compasso 83 .

Neste momento vale ressaltar um importante aspecto que Seidel constata após uma investigação de diversos exemplos musicais com o uso do Teufelsmühle apresentados em seu artigo de 1969: "Na música instrumental de Beethoven, o efeito patético do modelo de harmonização cromático torna-se reconhecível especialmente nos pontos culminantes do decurso do movimento inteiro[...]" (SEIDEL, 1969, p. 292).

É sabido que a linguagem musical da época de Beethoven, Schubert e Chopin, como ressalta Seidel, não é mais caracterizada pelo emprego das figuras retóricas de expressão. Contudo, o autor diz que provavelmente todos os exemplos de Haydn, Mozart, Beethoven e Schubert citados por ele em seu artigo podem conter resquícios da figura da pathopoiia. Entre as inúmeras obras expostas por ele constam algumas peças instrumentais do período de 1822 - 1825 escritas por Schubert, tais como o Scherzo da Wanderer-Phantasie D. 760 (comps. 564 e seguintes) e o Quarteto de cordas D. 810 em Ré menor, primeiro movimento (comps. 32 e seguintes e 37 e seguintes).

No caso do $O p .27$, de 1835, o ano de sua composição não está tão distante da época em que foram compostas estas obras de Schubert, por exemplo, que Seidel ressalta. Assim, voltando à exposição do Noturno Op. 27 no 1, é possível pensar que o fragmento nesta obra poderia ser também uma alusão a esta representação própria do Barroco, uma vez que o modelo cromático configura-se em tonalidade menor, com um baixo cromático descendente, associado a um recitativo, num momento decisivamente dramático e que constitui o clímax da peça. 
Embora a estrutura formal característica nos noturnos de Chopin seja ABA, no Op. 27 no 2 observa-se algo diferente, conforme atesta os comentários de Mieczyslaw Tomaszewski, presentes no encarte da edição do Facsimile:

[...] o Noturno em Réb maior é um daqueles em que a narrativa musical procede de acordo com princípios distintos. Ainda que a tripla aparição do tema principal pudesse sugerir a forma rondó, o caráter da obra (lento sostenuto) impossibilita este tipo de interpretação. A forma única e pouco comum do Noturno, nA1 B1 B2 $B 3$ u A2 B4 B5 x A3 B6 y C1 C2 z, pode ser definida como modelos "âncora-condensadores", com o tema $A$ sendo o elemento âncora da narrativa, formando um ponto constante de referência para a obra (TOMASZEWSKI, 2007, p. 20).

Outro aspecto a ser destacado na citação é o emprego das letras $n, u, x, y, z$ para referir-se às frases de "passagem" ou de "pontuação", assim como os momentos de abertura ou fechamento. Em linhas gerais, as letras descrevem as divisões motívicas que compõem as unidades estruturais da obra, de forma que contribui com determinados pontos que serão expostos a seguir por esta pesquisa ${ }^{15}$.

Assim, o gráfico geral do exemplo 97 interpreta, do ponto de vista formal, o $0 p .27$ $n$ 2 como uma peça constituída apenas por uma parte, uma vez que não contém elementos harmônicos, tonais e temáticos contrastantes suficientes que justifiquem sua classificação como uma forma binária, ternária, etc. Entretanto, isto não significa que a peça não possa ter inflexões formais menores, ou secundárias, como por exemplo, aquelas chamadas aqui de seções e nomeadas como: A, A', A" e Coda. Além disso, a macro-estrutura harmônica revela que não há, em nenhum momento, uma ruptura ou adoção de um novo centro tonal diferente à tonalidade de RébM, o que corrobora o posicionamento assumido por esta análise de que não existe modulação neste noturno.

Uma vez que a classificação sugerida por este tópico pressupõe a associação com os planos formal, harmônico, motívico, textural, dentre outros, justifica-se uma análise representada pelo gráfico no exemplo 97, com objetivo de facilitar a visualização e contextualização do emprego do Teufelsmühle na obra. Por fim, as indicações de dinâmicas citadas neste exemplo ganham importância em virtude do vínculo com a estrutura formal e preparação para o ponto culminante.

\footnotetext{
${ }^{15}$ É importante salientar que o autor não localiza os números de compassos referentes às letras $A$ e $B$ em sua análise, apenas em uma nota de rodapé situa a letras minúsculas $n, u, x, y$ e $z$.
} 
Exemplo 97 - Noturno Op. 27 no 2: gráfico geral

\section{Seção A}

compasso introdutório

$4 \quad$ 1a entrada do tema
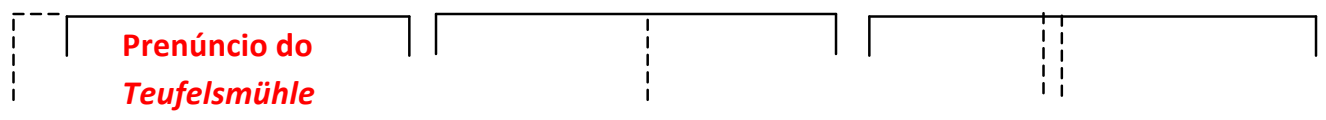

12

$910 \quad 14$

1718

2122

25

$\boldsymbol{P}$ dolce

espressivo

$f \quad p p$

RébM

"tonicização”

r---------I

Expansão da V de RébM e mistura de modos

Tom: RébM ।

vi

ii

V

\section{Seção $A^{\prime}$}

2a entrada do tema

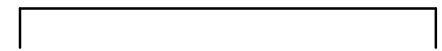

26

34

$38 \quad 40$

pp

dolce

cresc

RébM

"tonicização"

LáM (SibbM)

Tom: RébM

bVI

V

\section{Seção A"}

3a entrada do tema
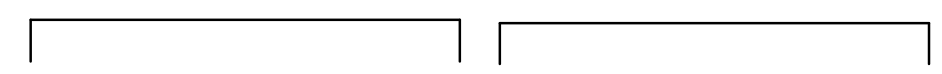

54

57

fff $\quad P P$

con anima

con forza

dolciss.

Tom: RébM

I

ii

sf

V

I

\section{Coda}

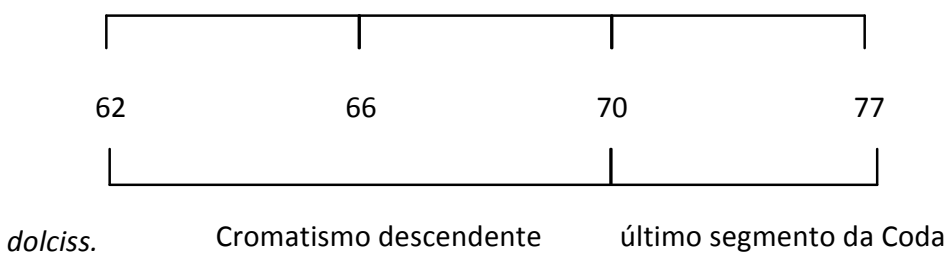

Tom: RébM 
É possível também encontrar, por vezes, aqueles que identificam modulações neste noturno, como pode ser observado na citação a seguir, extraída dos comentários de Fontana ${ }^{16}:$....] a segunda vez, pianíssimo [referindo-se à segunda entrada do tema no compasso 26] - assistida pelo segundo (uma corda) pedal, a qual é perfeitamente justificada pelo caráter e a modulação que a prepara [...]" (EIGELDINGER, 1991, p. 80). A passagem do noturno que Fontana assume como uma modulação (Ex. 98), corresponde ao trecho analisado por M. Tomaszewski como frase de passagem e sinalizada com a letra " $u$ ".

\section{Exemplo 98 - Noturno Op. 27 no 2: comps. 22 - 25}

\section{Suspensão}

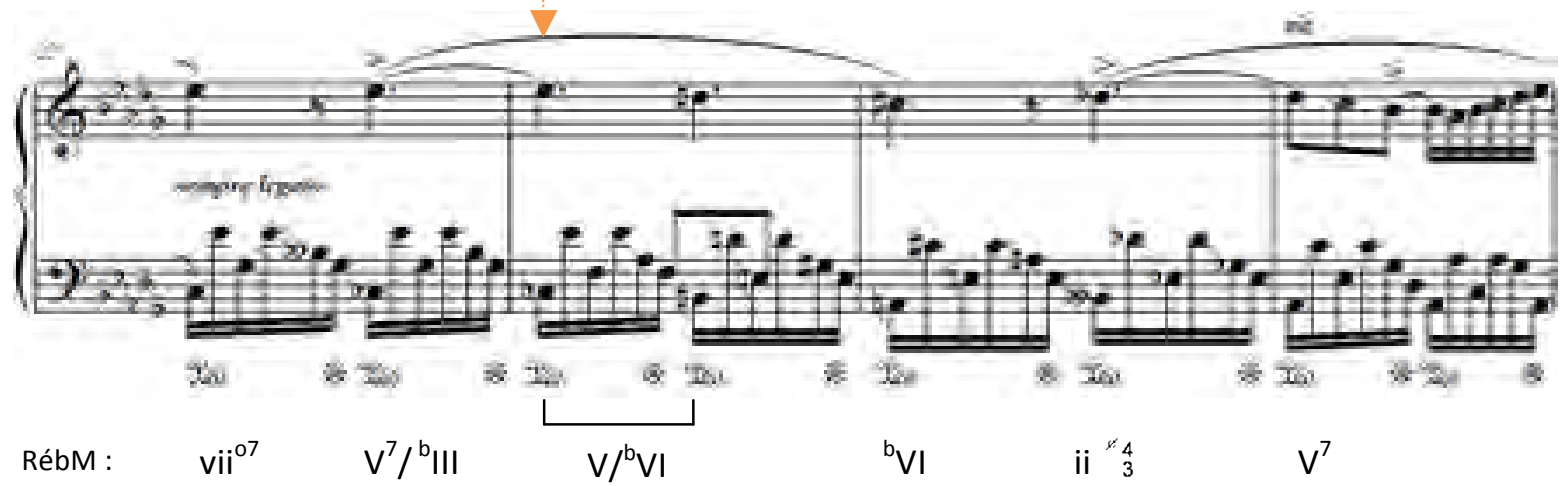

Classificado por esta pesquisa como o último fragmento da seção A (Ex. 98), a passagem dos compassos 22 a 25 apresenta um cromatismo empregado em diferentes vozes e já anuncia um procedimento que, mais tarde (comps. 40 a 45) será retomado por Chopin de forma ampliada como Teufelsmühle. Além disso, a mistura de modos (RébM/m) que ocorre no segmento dos compassos 22 - 25 propicia um contraste musical sem modulação, à medida que mantém a mesma tônica, ou seja, o mesmo centro tonal e todas as relações de hierarquia e funções harmônicas vinculadas à Réb. Entretanto, isto não é facilmente identificado devido ao cromatismo e das contínuas enarmonizações, utilizadas para facilitar a grafia musical. Por esta razão, cabe aqui um detalhamento para aclarar o plano harmônico da passagem e sua relação com o plano tonal da peça (Ex. 99). É possível observar neste exemplo a redução com a análise harmônica da passagem, assim como a classificação da nota Mib do compasso 23, assinalada em laranja, como uma suspensão.

16 Julian Fontana (1810 - 1869), pianista polonês, foi compositor e trabalhou como um dos principais copistas de Chopin. 
Exemplo 99 - Op. 27 no 2: redução, comps. 22 - 25

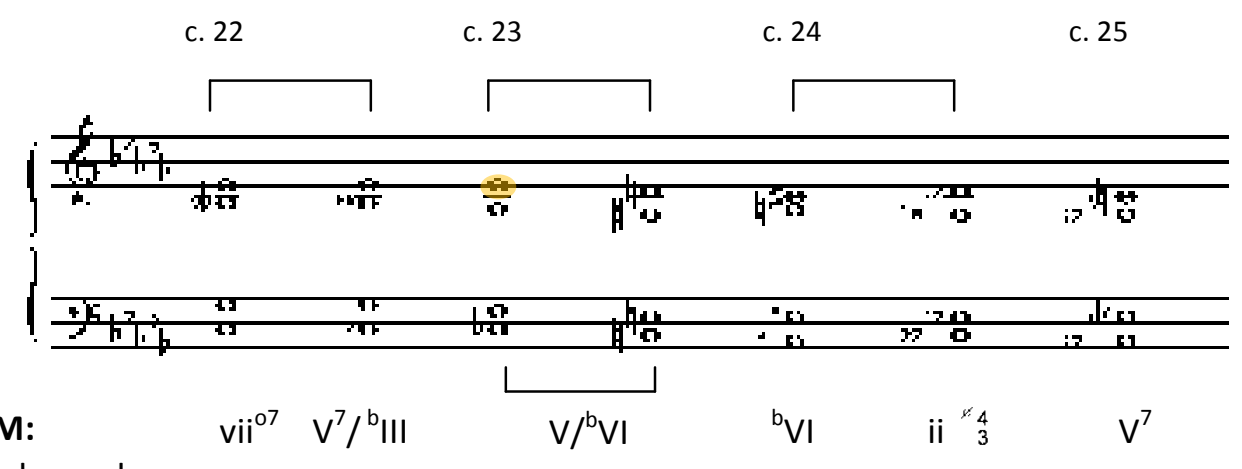

com mistura de modos

acordes enarmonizados: $\quad$ Fáb $^{7} \quad$ SibbM

O emprego do acorde de sétima diminuta (Dó diminuto no compasso 22) já anuncia a passagem para Réb menor e encontra-se seguido por uma seqüência de dominantes $V^{7} /{ }^{b} I I I$ $\left(D^{\prime} b^{7}\right.$ ) e $V^{7} /^{b} \mathrm{VI}$ (Fáb ${ }^{7}$ enarmonizado para $\mathrm{Mi}^{7}$ ). O uso dos acordes Dób ${ }^{7}$, Fáb ${ }^{7}$, SibbM, Mib meio diminuto e Láb ${ }^{7}$ demonstra a presença de um padrão em quintas descendentes (círculo de quintas), envolvendo o uso de duas dominantes secundárias sucessivas e mistura de modos. Esta exposição justifica a perspectiva adotada para reiterar a colocação de que não se trata de uma modulação, mas sim de um sofisticado uso da condução de vozes, num trecho de transição que atua como uma expansão cadencial rumo à dominante do tom.

Embora a passagem descrita no exemplo 99 contenha alguns elementos pertinentes às sequências cromáticas estudadas aqui, o emprego do Teufelsmühle, de forma bastante dilatada e com função de preparação para o ponto culminante, só se confirma nos compassos $40-45^{17}$.

Já nos compassos 7 e 8 deste noturno um fragmento variado do Teufelsmühle é empregado como elemento que compõe a primeira frase da peça, de forma que é possível classificá-lo também como um prenúncio ${ }^{18}$. Assim, esta apresentação de forma abreviada conserva o mesmo diminuto gerador dos compassos 40 - 45 do Teufelsmühle, bem como algumas tipologias e parte da condução de vozes.

O exemplo 100 ilustra o prenúncio e o Teufelsmühle com suas respectivas tipologias de acordes, que estabelecem, inicialmente, o vínculo entre os dois trechos. As cores utilizadas no exemplo seguinte permitem constatar a correspondência entre acordes e a ordem

\footnotetext{
${ }^{17}$ Os compassos 42 - 45 são classificados por Tomaszewski como uma frase de passagem, grafada em sua análise pela letra " $x "$ ", com função de pontuação e que introduz a terceira entrada do tema A (TOMASZEWSKI, 2007, p. 20, nota 12).

${ }^{18}$ Este fragmento, também repetido nos compassos 31 e 32, é utilizado no Op. 27 no 2 como um elemento temático, de forma análoga à análise feita por Seidel na Sinfonia da Montanha de Liszt (1981, p. 175 - 178).
} 
retrógrada de apresentação nas duas passagens, em decorrência do emprego do baixo descendente no prenúncio e do baixo ascendente no Teufelsmühle.

Exemplo 100 - Noturno Op. 27 no 2: prenúncio e o Teufelsmühle

a) Comps. 6 - 9

Prenúncio do Teufelsmühle

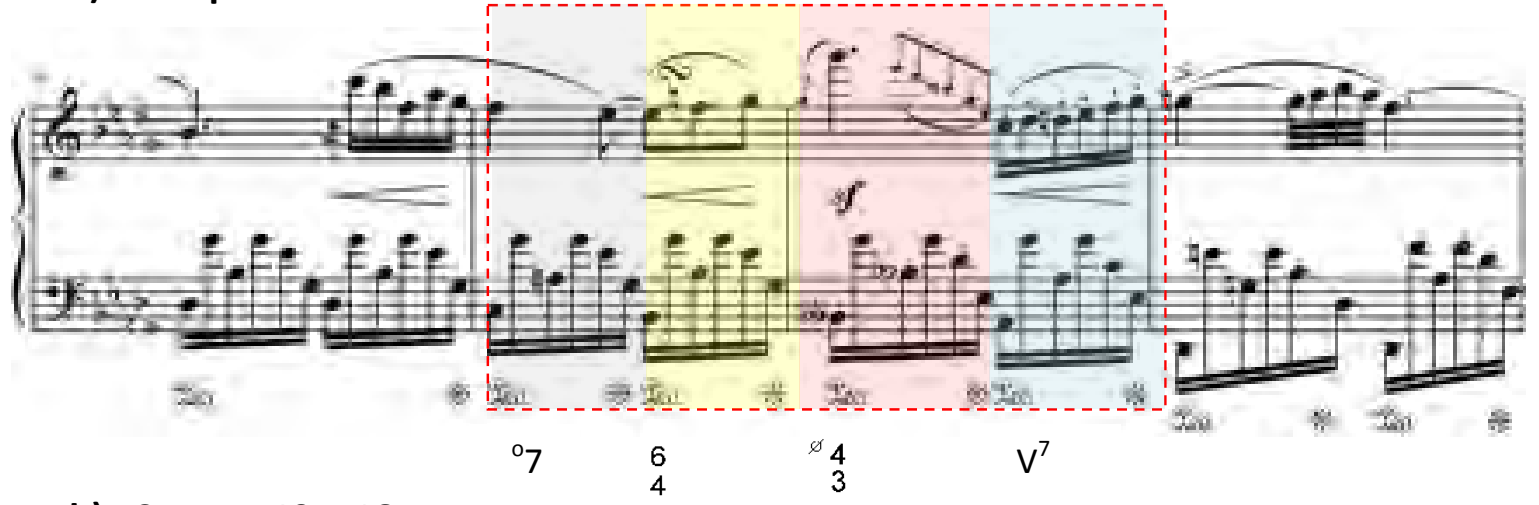

b) Comps. $40-46$

Teufelsmühle versão $A B$ com variantes
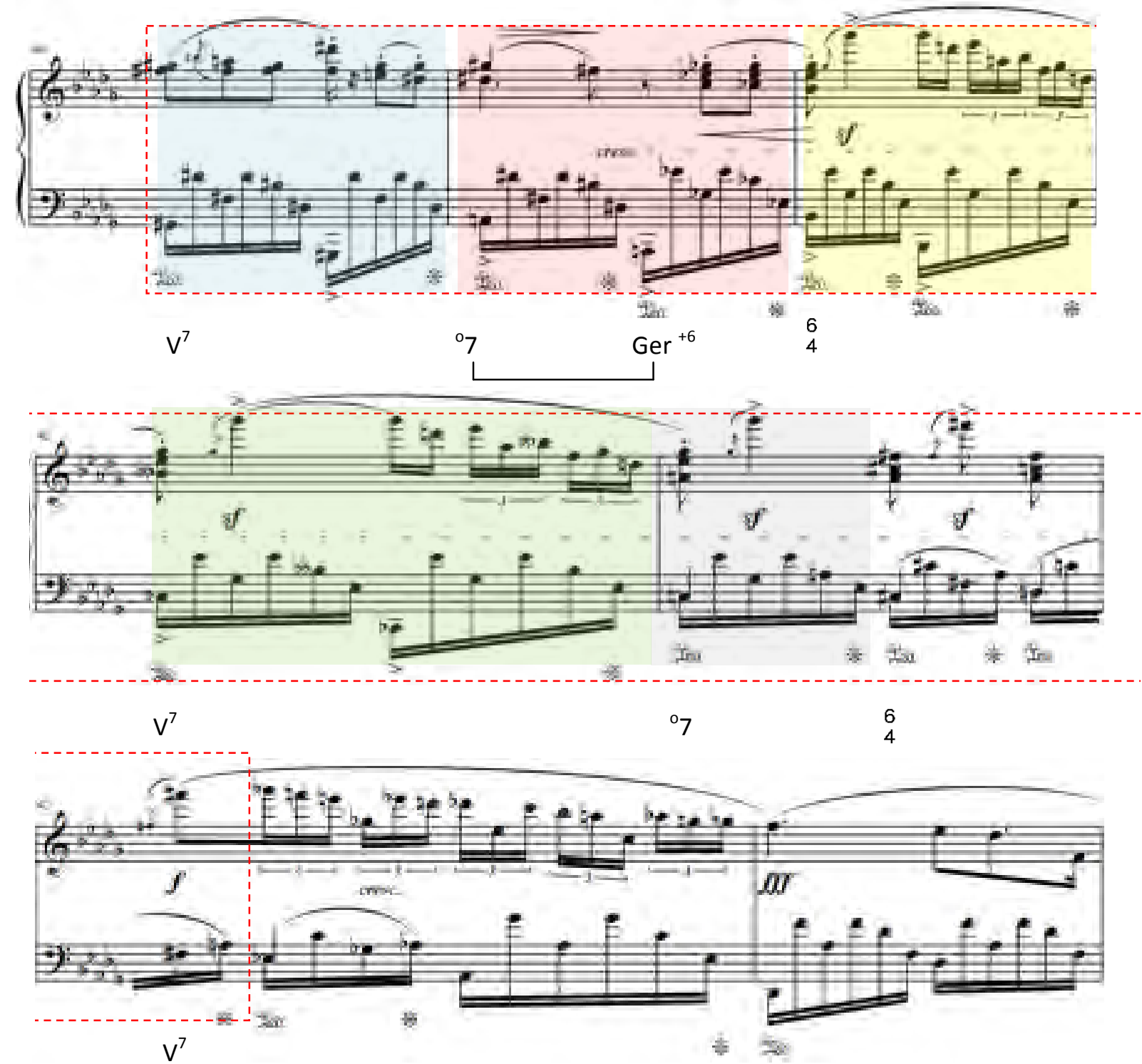
Na redução do exemplo 101 encontram-se destacados os acordes que compõe o prenúncio do Teufelsmühle com duas variantes: a omissão da $\operatorname{Ger}^{+6}$ no compasso 7 e a substituição para um acorde meio diminuto com sétima no compasso 8 , ao invés da $\mathrm{V}^{2} / \mathrm{Ger}^{+6}$ prevista na versão B. O último acorde desta sequência (Lab7) assume um duplo papel, à medida que se configura, ao mesmo tempo, membro do Teufelsmühle e parte do movimento cadencial à Reb maior.

\section{Exemplo 101 - Redução: prenúncio, comps. 7 - 8}

c. 7

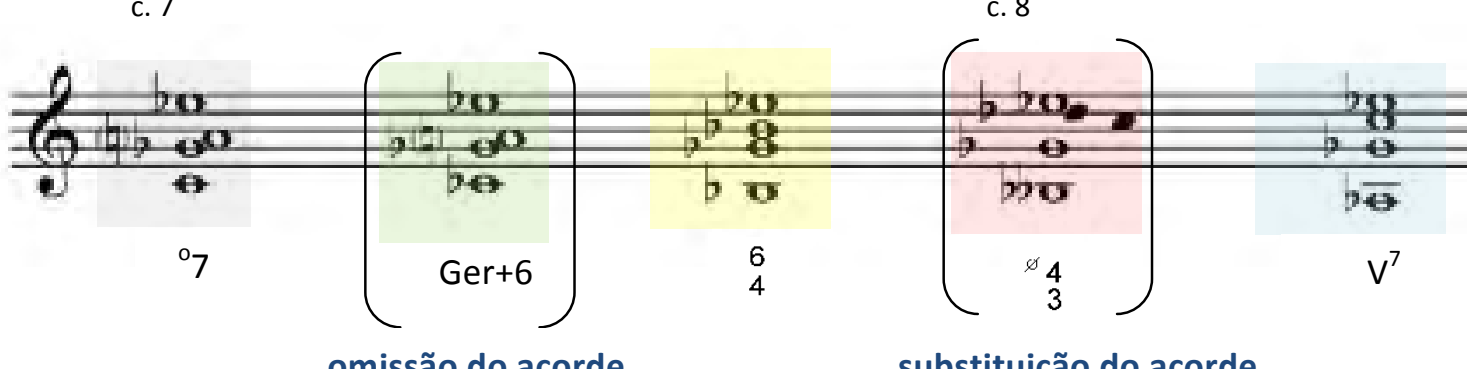

omissão do acorde

substituição do acorde

Sobre a condução de vozes, observa-se ainda no prenúncio que novamente o pedal em relação de terça menor, formado pelas notas Mib e Solb, constituem alturas principais da mão direita, que são ornamentadas com figurações melódicas (Cf. Ex. 100a). Ainda nesta perspectiva, a mão esquerda possui de forma explícita a linha cromática do baixo (Dó, Sib, Sibb, Lab), as notas do pedal e apenas uma menção ao outro cromatismo, devido à omissão e alteração de acordes da sequência.

O último segmento da seção $A^{\prime}$ (comps. 38 - 45) configura-se numa transição para a volta do tema inicial, na qual a harmonia que vigora é a de dominante. Os compassos 38 e 39 antecedem a entrada do Teufelsmühle (comps. 40 - 45), que por sua vez, anuncia o retorno do tema na seção $A^{\prime \prime}$ no compasso 46 (Ex. 102).

Exemplo $102-O p .27$ no 2: comps. $38-46$

último segmento da seção $A^{\prime}$

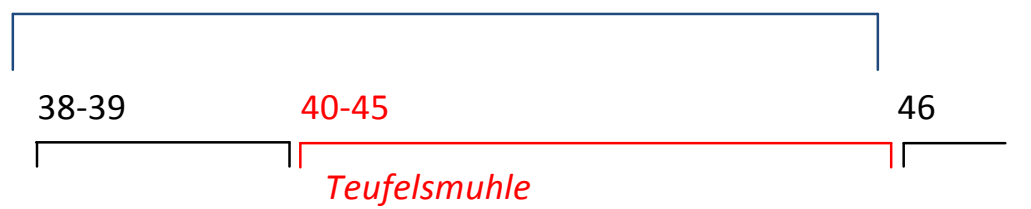

Réb $M / m$ : 
O exemplo a seguir ilustra a redução dos compassos $40-45$, na qual inicialmente são encontradas quatro tipologias: dominante com sétima; acorde diminuto que se desdobra em acorde de sexta aumentada; e acorde menor com quarta e sexta. Uma vez que o compasso 41 apresenta tanto o acorde diminuto, característico da versão $A$, como a germânica, própria da versão $B$, uma interpretação como versão $A B$ entre os compassos 40 a 42 é possível. A sequência continua com um dominante com sétima, diminuto com sétima e acorde menor com quarta e sexta, claramente a versão $A$. A progressão ainda possui o Ré ${ }^{7}$ no final do compasso 44 como pertencente ao modelo cromático, entretanto, neste momento o padrão é interrompido e este acorde é imediatamente transformado na dominante principal do tom. As cores no exemplo 103 estão indicadas para que se possa estabelecer uma correspondência com os exemplos 100 e 101.

Exemplo 103 - Redução: Teufelsmühle, comps. 40 - 45

3a menor acima

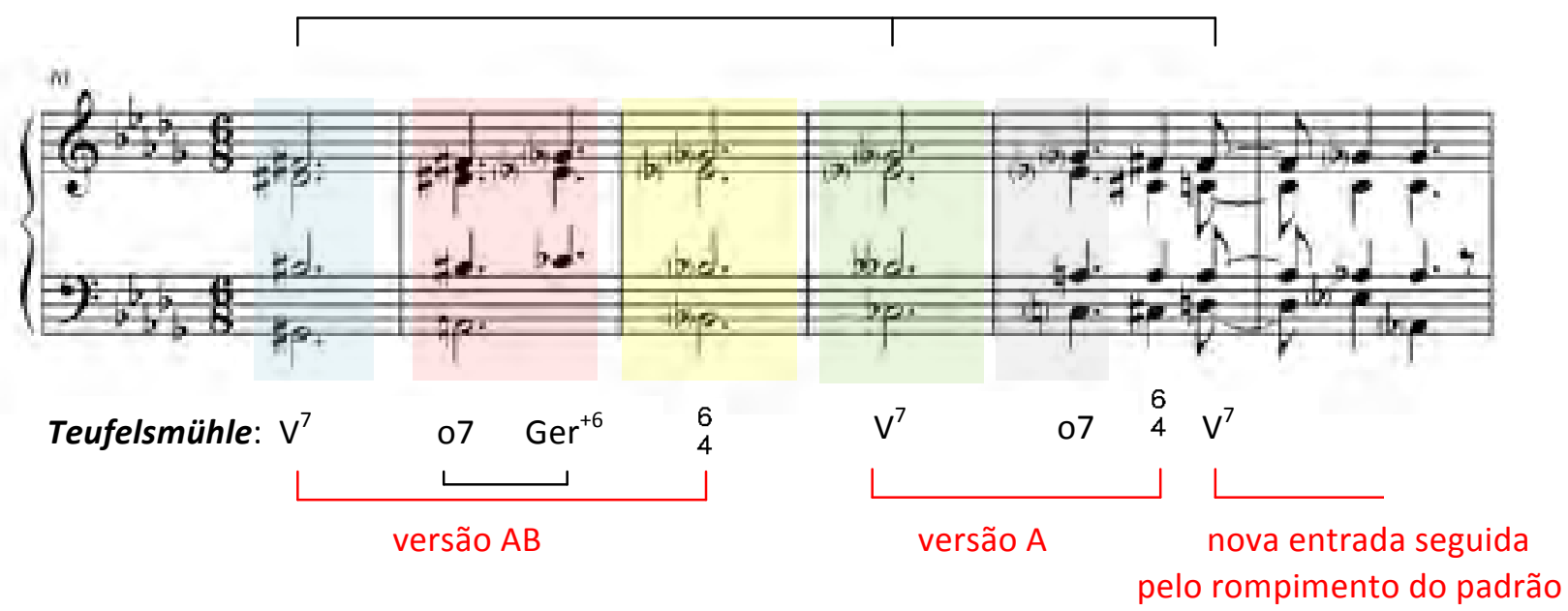

Análise de Yellin:

O (Ré\# - Fá\#):

(4)

(3)

(2) (1)

O (Fá\#-Lá) (5) ${ }^{\circ}$ (3) (2)

Portanto, esta redução permite constatar que se trata da versão $A B$ do Teufelsmühle com sete acordes e sem variantes a partir do diminuto gerador Dó ${ }^{\circ}$. Em contrapartida, ainda sobre o exemplo 103 torna-se possível observar a análise feita por Yellin desta passagem do Op. $27 n$ ㅇ 2, na qual o autor assume duas alterações em relação ao seu padrão clássico no 
compasso 44: a substituição do (1) pelo (1) ${ }^{\circ}$ e uma mutação para a série O (Fá\#-La) ${ }^{19}$. Assim, esta pesquisa entende que uma interpretação como Teufelsmühle deste trecho seja mais adequada, pelo fato do padrão cromático apresentar uma exata correspondência com as versões de Seidel.

O contexto extremamente elaborado de polifonia com que Chopin emprega o Teufelsmühle nesta passagem, devido principalmente às dissimulações por meio de figurações melódicas e deslocamentos rítmicos, torna difícil um imediato reconhecimento das versões $A B$, muito embora se trate de um padrão sem variantes. Além disso, outro fator que novamente dificulta tal identificação diz respeito às enarmonizações de notas empregadas para facilitar a grafia e a leitura musical. Por estas razões, o exemplo seguinte ilustra novamente a passagem musical dos compassos $40-46$, com o intuito de aclarar a maneira com que se configura a condução de vozes.

O exemplo 104 permite observar que todas as notas que compõe a mão esquerda são advindas do Teufelsmühle, no entanto, chama atenção como estas alturas são organizadas. O cromatismo ascendente está colocado, de forma geral, em tempos fortes e no registro mais grave, o que evidencia esta linha por toda a passagem, destacada em azul. Por outro lado, o que tende a ficar obscurecido, de maneira similar ao Estudo Op. 25 no 11 (Ex. 57), é o cromatismo descendente da progressão, que neste caso está disposto sempre no mesmo registro e de forma predominante na quinta semicolcheia de cada grupo, com exceção do compasso 44, como assinalado em vermelho. Ainda na mão esquerda, nota-se que o pedal Ré\#-Fá\# também é apresentado em determinadas regiões do campo da tessitura, como destacado em amarelo.

\section{Exemplo 104 - Noturno Op. 27 no 2, comps. 40 - 46, ênfase na condução de vozes}

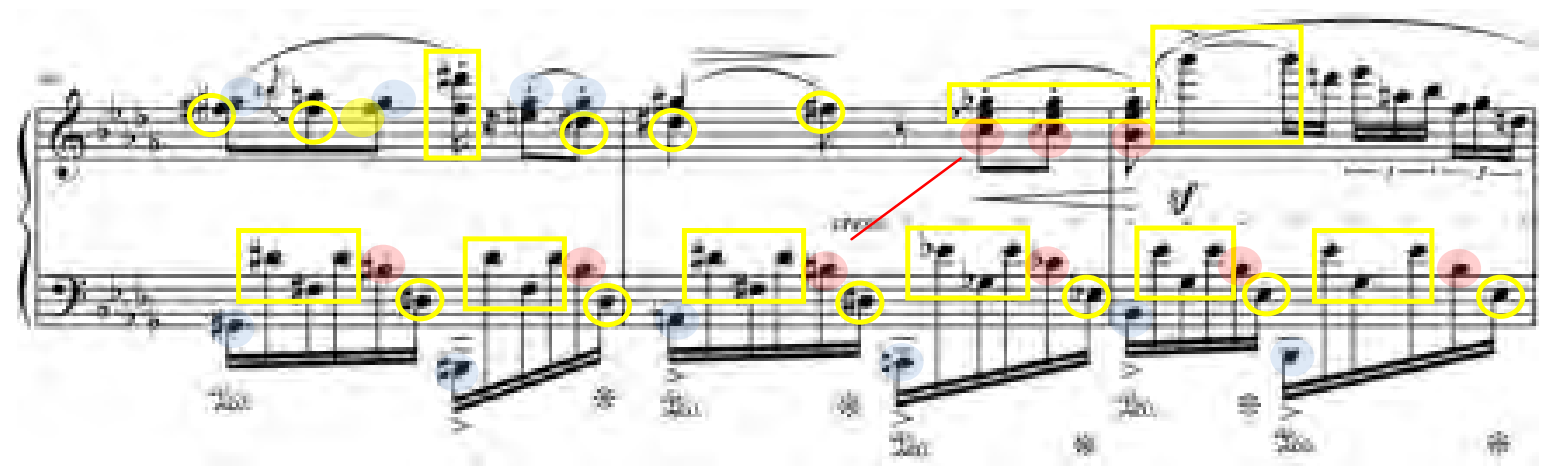

\footnotetext{
${ }^{19}$ Alguns erros de impressão são encontrados na descrição da passagem em questão feita por Yellin, tais como as omissões das indicações de diminuto nos acordes (1) e (4) no texto, assim como a cifragem do (5) ${ }^{\circ}$ ao invés do (4) no compasso 44 em seu exemplo 58 (YELLIN, 1998, p. 53 - 54).
} 

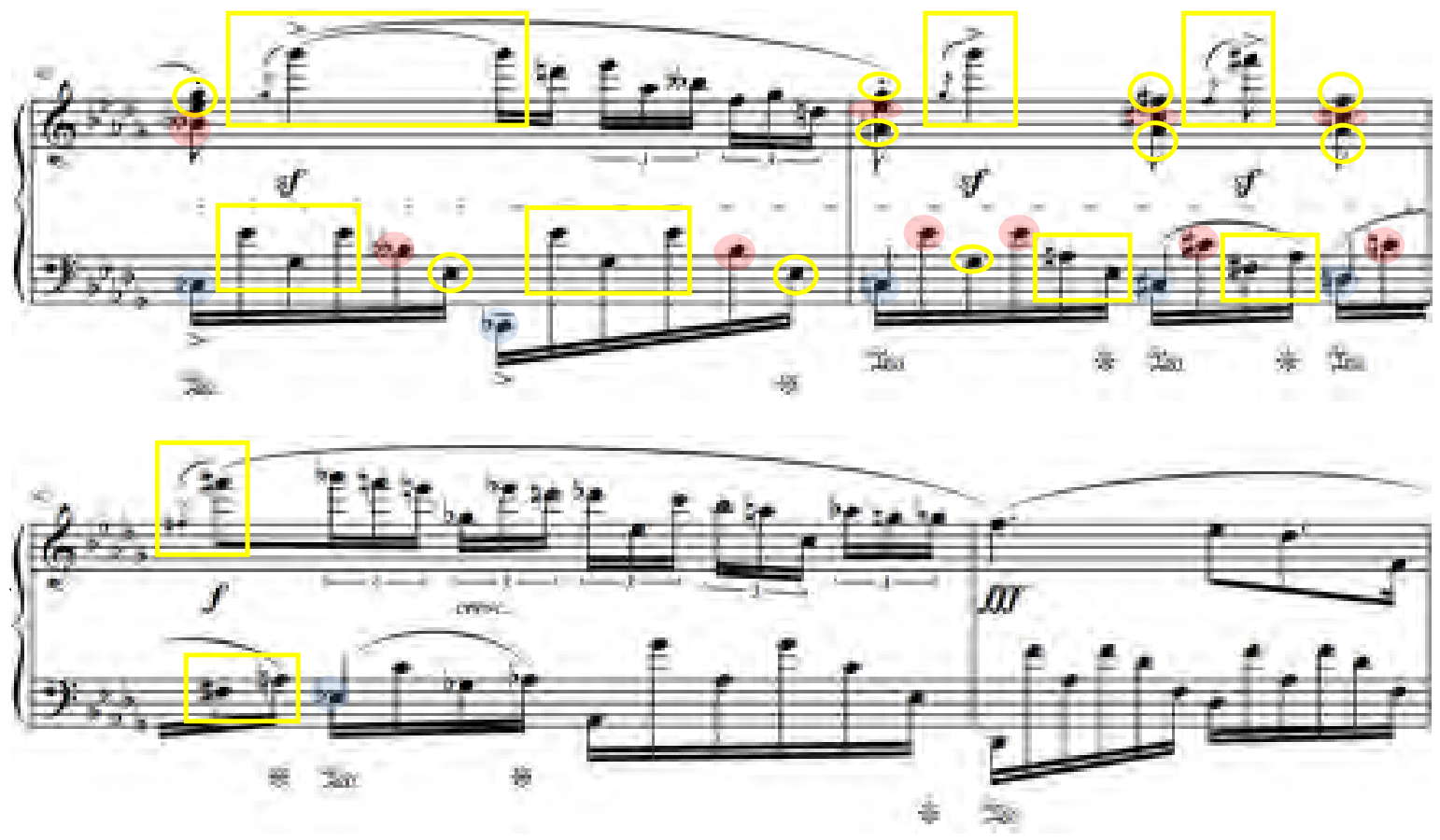

Embora se possa observar a presença do cromatismo descendente na mão direita, é importante ressaltar que mais uma vez Chopin constrói a linha com uma nota mantida do pedal, mas desta vez com um elevado grau de elaboração. A nota Fá\#/Solb encontra-se na região mais aguda, constitui a altura principal, ornamentada com figurações melódicas por toda a passagem e recebe indicações de $s f$ com apojaturas em oitava do compasso 42 até o compasso 45. Além disso, o papel desta nota, do ponto de vista da macro-estrutura harmônica, define todo o trecho como uma extensão da dominante principal, em que Solb, a sétima do acorde, resolve na terça do primeiro grau de Réb maior no compasso 46.

Vale destacar também que este gesto da apojatura em oitava sobre a nota Solb já acontece no tempo forte do compasso 8 do prenúncio, o que representa mais um aspecto musical que fortalece o vínculo entre as duas passagens.

Por fim, esta preparação para o ponto culminante da peça encontra-se caracterizada por uma aceleração do ritmo harmônico do Teufelsmühle, uma vez que ocorre nos compassos $40-43$ apenas uma tipologia por compasso, enquanto que o 44 é marcado por três acordes da sequência cromática. Além disso, esta maior movimentação rumo ao clímax é também sinalizada por Chopin, que grafa uma espécie de acelerando das durações a partir dos compassos 44 - 45 (cf. Exs. 103 e 104), associado ainda a uma intensificação da dinâmica, que atinge seu ponto máximo com o fff no compasso 46. 
Em suma, o Op. 27 no 2 possui o andamento Lento sostenuto e a passagem dos compassos 40 - 45 está inserida no modo menor (Réb m por mistura de modos, cf. ex. 97), com o baixo cromático ascendente e no ponto de maior dramaticidade da peça.

Assim, a observação seguinte feita por Telesco, embora seja referente ao padrão do omnibus, se faz pertinente e possui uma correspondência com os pontos destacados nesta análise do Op. 27:

[...] mesmo se a progressão omnibus não mais contivesse conotações específicas do lamento para os compositores da era clássica, ela ainda continha muito do peso retórico e dramático de sua origem nos baixos de Passaglia e Arias de lamento, e portanto, seria uma escolha apropriada para o clímax dramático de uma composição (TELESCO, 1998, p. 274). 
A busca para aclarar determinadas passagens que se revelavam como sonoridades familiares na práxis composicional de Chopin, mas que permaneciam sem respostas convincentes por meio de estudos tradicionais nas áreas de harmonia e análise, foi um dos primeiros motivos que instigou a realização desta pesquisa. Neste sentido, ao entrar em contato com a referência bibliográfica de Yellin, inicialmente, algumas associações foram imediatamente promovidas. Entretanto, foi principalmente a integração com os estudos realizados por Elmar Seidel, que incluem demonstrações na música de Liszt, que suscitou uma investigação específica sobre a presença, assim como da importância que as estruturas do Teufelsmühle e omnibus poderiam vir a assumir em Chopin.

A localização e descrição destas sequências em sua obra se configuraram apenas como um momento inicial para que se vislumbrasse o entendimento estrutural, o vínculo formal e musical, além do modo com que o mestre polonês fez uso destes modelos cromáticos.

Tamanha abrangência exigiu uma ampliação no escopo das investigações, de modo que uma explanação mais detalhada dos aspectos estruturais foi realizada na primeira parte desta dissertação. Nesta etapa, conceitos foram expostos, comentados e exemplificados de forma isolada e contextualizada em obras de diferentes autores, gêneros e períodos musicais. Torna-se relevante frisar que a dificuldade gerada pela falta de integração e contato entre as correntes americana e alemã motivou a elaboração de um texto com uma preocupação didática e assim comprometida com a criação de pré-requisitos e organização dos conteúdos. Além disso, a elaboração de categorias capazes de abarcar as diferentes formas de manifestação, tanto do Teufelmühle quanto do omnibus, se fez imprescindível para a compreensão e aplicação posterior em exemplos musicais da obra de Chopin.

Assim, a seguir serão feitas algumas considerações gerais sobre os principais aspectos característicos ao Teufelsmühle e ao omnibus, assim como implicações destas estruturas para a prática musical.

Um ponto exposto no primeiro capítulo e que se faz pertinente neste momento tratase de uma das questões estruturais implícitas no Teufelsmühle, suas possibilidades de modulações a partir das reinterpretações enarmônicas. De certa forma, quando o padrão clássico do omnibus é interrompido ou apresenta mutações, sua função praticamente se 
equipara e está intimamente relacionada ao Teufelsmühle versão B. Assim, a citação seguinte, extraída de um comentário de Telesco, embora seja referente apenas às progressões do omnibus e Vogler/omnibus, resume e pode ser utilizada para caracterizar os modelos cromáticos em geral:

[...] uma progressão exoticamente colorida, cromática, mas com utilidade de levar a música de uma tonalidade a outra, próxima ou distante, fornecendo um trajeto enarmônico extravagante pelo caminho (TELESCO, 1998, p. 276).

A liberdade propiciada pelas trocas de posicionamento dos acordes do Teufelsmühle, vinculada a diferentes diminutos geradores, permite enfatizar, ainda mais, a instabilidade e incerteza tonal gerenciadas pelas propriedades inerentes à reinterpretação enarmônica, à propensão de modulação e repentinas trocas de direcionamento cadencial. Esta natureza prioritariamente harmônica não minimiza, de forma alguma, o aspecto horizontal intrínseco deste princípio. No entanto, foi possível identificar que as versões do Teufelsmühle não possuem um padrão de conduções de vozes definido. Justamente este fator, associado ainda às inúmeras disposições de tipologias é que pode propiciar, por vezes, as mais variadas apresentações dentro de uma obra e assim acarretar em uma complexidade que dificulta o reconhecimento das progressões.

Desta forma, é esta abrangência do Teufelsmühle, tanto do ponto de vista harmônico quanto melódico, que possibilita considerar o padrão clássico formulado por Yellin como uma "espécie de variante" do Teufelsmühle. Neste sentido, as análises realizadas em diversas passagens musicais permitiram perceber que apenas o acorde (1) é típico do omnibus, ao passo que os outros podem ser, naturalmente, interpretados como parte das versões $A$ ou $B$ do Teufelsmühle. Por esta razão, é comum que interpretações como Teufelsmühle já se aproximem mais do modelo de harmonização codificado por Vogler enquanto que uma explicação de acordo com o Yellin prevê mais variantes em relação ao seu padrão clássico (Cf. exemplos 81 e 103).

Contudo, esta questão não se encerra aqui e permite ainda uma reflexão entre as principais similaridades e diferenças entre as duas vertentes de pesquisa. $O$ fato é que, embora a progressão omnibus seja também descrita com formações de acordes, sua origem é essencialmente horizontal, ou seja, foi concebida a partir da presença de duas vozes mantidas e de outras duas que realizam movimento contrário, cromático e simétrico. Esta conclusão 
alcançada por Yellin constitui um importante aspecto que auxilia de forma significativa tanto a classificação do omnibus como a do Teufelsmühle.

Inicialmente, a identificação das sequências pode ser facilitada pelo reconhecimento auditivo do cromatismo, usualmente na linha do baixo, e das tipologias dos acordes envolvidos. Numa etapa seguinte, a análise do material selecionado envolve a observação das notas mantidas como pedal, que revela, dentre outras coisas, a presença de mutações, no caso do omnibus, ou de mudanças de transposições, que naturalmente implicam na troca do diminuto gerador.

Por outro lado, deve-se ter uma atenção em relação a esta visão da polifonia ressaltada por Yellin. Fora constatado que as quatro vozes do omnibus podem estar dispostas de diferentes maneiras, tais como: vozes cromáticas no baixo e tenor enquanto as notas do pedal estão no contralto e soprano; cromatismo nas vozes internas ao passo que as notas do pedal se apresentam nas vozes extremas ${ }^{1}$, etc. Enfim, existem combinatórias, mas que, de qualquer forma, mantêm o princípio de quatro linhas com características bem definidas. Neste sentido, o conhecimento apenas da visão americana pode induzir uma condução de vozes prévia e assim limitar o reconhecimento, por exemplo, das diversas variantes na literatura musical.

Retomando o problema levantado logo no início destas conclusões, a hipótese de investigação e reconhecimento dos modelos cromáticos na obra de Chopin se tornou viável principalmente após o contato com os estudos de Seidel, que revelaram a visão harmônica do Teufelsmühle, assim como suas diferentes formas de apresentação no repertório e seu parentesco com o segundo modo de transposição limitada de Messiaen. Em outras palavras, a identificação das diversas ocorrências em Chopin foi possível somente após o estudo das duas correntes de pesquisa, a partir da integração dos aspectos horizontais e verticais da composição.

Neste ponto, torna-se relevante destacar uma diferença de posicionamento em relação à Dittrich, uma vez que a autora diz assumir uma passagem como omnibus somente quando se trata exatamente dos cinco acordes encontrados na definição de Yellin. Portanto, a conduta da pesquisadora alemã enfatiza o aspecto harmônico e não prioriza as questões relacionadas à condução de vozes das sequências cromáticas.

Feitas estas colocações é possível esclarecer que, diante de exemplos musicais que apresentam uma condução de vozes que resguarda o padrão clássico de Yellin, independente da quantidade de acordes, fora adotada por esta pesquisa uma interpretação como omnibus ao invés de Teufelsmühle (Cf. Ex 59b), embora uma visão com Teufelsmühle também seja

\footnotetext{
${ }^{1}$ Um exemplo deste uso ocorre no segundo movimento da Terceira Sonata de Chopin (comps. $\left.103-108\right)$.
} 
adequada. Assim, a escolha entre Teufelsmühle ou omnibus foi feita também a partir de um vínculo com a escuta, ou seja, da maneira com que a progressão foi identificada na passagem musical.

De certa forma, uma preocupação com o reconhecimento auditivo de determinadas sonoridades "familiares" foi também o que instigou Yellin a iniciar sua pesquisa, que partiu da hipótese de que o problema estava na sintaxe da harmonia cromática e não no som. Nesta perspectiva, o próprio autor destaca que a sua nomenclatura propicia a identificação de acordes individuais por sua posição na série, ressalta a importância da progressão como um todo e evita ambigüidades de terminologias conflitantes. Acrescenta também que reduz a confusão de cifragens envolvendo enarmonias e assim torna-se algo mais proveitoso do que tentar nomear estes acordes em alguma tonalidade particular (YELLIN, 1998, 4).

Além disso, uma das maiores contribuições dos estudos de Yellin fora a montagem de um catálogo com a seleção de obras em diferentes épocas, gêneros e estilos musicais, que promoveu um levantamento destas sonoridades aparentadas e seu percurso histórico.

Outro ponto muito relevante observado pelo americano diz respeito ao fato de que estas progressões ainda não são devidamente explicadas, de modo geral, em livros didáticos de harmonia. De fato, não é raro se deparar com citações e trechos musicais analisados com enfoques diferentes que demonstram como tais estruturas cromáticas passaram despercebidas por muito tempo. Um exemplo encontrado por esta pesquisa ocorre no livro Funções Estruturais da Harmonia (1954) de Arnold Schoenberg, quando o autor faz o seguinte comentário: "Ele [Schubert] vai ainda mais longe ao utilizar progressões harmônicas estranhas [...]" (SCHOENBERG, 2004, p. 107), ao se referir à passagem dos compassos 55 - 67 do Lied Wegweiser de Schubert ${ }^{2}$.

Uma referência atual em harmonia que se propõe a explicar estas estruturas pode ser vista no livro Harmony in Context de Francolí. No capítulo 27, dentro do item intitulado "sequências cromáticas", o autor cita como único exemplo musical de omnibus a Mazurka Op. 59 no 2 de Chopin. Na realidade trata-se de uma passagem complexa, que envolve fragmentos do Teufelsmühle em sequência, o que torna mais difícil até mesmo uma interpretação como variante do omnibus. Após sua análise, Francolí conclui e comenta que o trecho da mazurka é "uma ligeira variação de uma progressão cromática padrão conhecida

\footnotetext{
${ }^{2}$ Para mais informações sobre a análise do Teufelsmühle neste Lied, conferir Seidel (1969, p. 285 - 287).
} 
como omnibus" [...] "o omnibus no exemplo $27.15 d$ é simplesmente um prolongamento linear cromático de um acorde de Fá maior com sétima“" (FRANCOLí, 2003, p. 804) ${ }^{3}$.

Assim, as observações feitas por Yellin se mostram atuais, como comprovam as citações acima, o que permite destacar que se trata de um assunto ainda pouco explorado nesta área.

Retomando os principais pontos advindos da corrente americana, sobre Paula Telesco, vale destacar algumas deduções alcançadas pela autora após sua pesquisa das progressões omnibus e Vogler/omnibus, realizadas principalmente na música do período clássico. A citação a seguir, extraída do seu artigo de 1998, demonstra o seguinte posicionamento:

De fato, é difícil encontrar uma passagem omnibus do século XVIII que seja simplesmente isso: um prolongamento direto de dominante, sem nenhuma apresentação sobreposta [em outras palavras, sem nenhuma mutação do omnibus] (TELESCO, 1998, p. 275).

Logo em seguida a autora acrescenta então que "os exemplos do século dezoito funcionam, via de regra, de uma maneira tonalmente mais ambígua do que aqueles do século XIX, onde os omnibus clássicos são relativamente mais fáceis de serem encontrados" (TELESCO, 1998, p. 275).

As colocações extraídas das conclusões da pesquisadora americana Paula Telesco podem induzir uma visão reducionista, de que apenas o padrão clássico exposto por Yellin é comum no romantismo. De fato, o Teufelsmühle ocorre tanto na música do século XVIII quanto na música do século XIX, seja igual ao padrão exposto por Vogler, parcialmente ou com variantes, como demonstrado em diversas passagens extraídas da obra de F. Chopin.

Ocorre que, talvez a falta de diálogo com os estudos realizados pelos alemães tenha dificultado o reconhecimento do Vogler/omnibus e suas diferentes aparições no período romântico pelos americanos. Isto decorre do fato que no romantismo estas sequências podem incluir variantes e estar inseridas em contextos que envolvem uma escrita composicional com uma polifonia muito elaborada e, por vezes, não explícita.

\footnotetext{
${ }^{3}$ De fato pode-se entender a passagem, no todo, como uma extensão do acorde de Fá maior com sétima, entretanto, em nenhum momento Francoli expõe e define o padrão clássico de Yellin, tampouco detalha como é feita esta complicada variante na Mazurka Op. 59 no 2. Por se tratar de um livro didático, talvez a escolha deste exemplo não seja apropriada para uma exposição inicial, uma vez que este assunto é abordado apenas neste item de seu livro.
} 
Por outro lado, freqüentemente as análises promovidas por Telesco contextualizam o uso das progressões cromáticas, especialmente em obras do classicismo, no que diz respeito aos momentos formais nos quais as sequências estão inseridas. Não obstante, suas observações revelam e traduzem algumas das notáveis características do omnibus ou Vogler/omnibus e que podem, naturalmente, ser igualmente assumidas nas versões do Teufelsmühle:

Enquanto alguns dos exemplos que eu examinei mostram as progressões omnibus em passagens de desenvolvimento e transição, como se poderia esperar para uma harmonia de tal ambigüidade e instabilidade - os compositores também as usam naquele que poderia ser normalmente seções estáveis da música. Isto cria um elemento de surpresa, permitindo incursões em tonalidades remotas nos lugares mais inesperados (TELESCO, 1998, p. 272).

Outro aspecto levantado pela pesquisadora americana, que constitui um ponto relevante e que pode estar vinculado aos modelos cromáticos, são as hipóteses de origem das progressões no baixo de passacaglia e Aria de Lamento. Esta questão, associada aos resultados obtidos também por Seidel em sua pesquisa, contribuíram para o estabelecimento de alguns paralelos feitos por esta pesquisa, em determinadas peças de Chopin, com o contexto de incerteza, melancolia, dor e morte.

Assim, a partir desta exposição acerca das considerações sobre as sequências cromáticas, bem como das contribuições advindas dos principais representantes das duas vertentes de pesquisa, é possível destacar alguns pontos específicos encontrados no emprego do Teufelsmühle e omnibus na música de Chopin.

Primeiramente, torna-se importante frisar que os modelos cromáticos ocorrem em praticamente todos os gêneros musicais escritos pelo compositor. De modo geral, foi possível observar também uma preferência pelo uso do Teufelsmühle, seja com ou sem variantes, ao invés do padrão clássico descrito por Yellin.

Não é difícil imaginar o porquê desta tendência, uma vez que Chopin está inserido numa estética musical marcada pela ambigüidade e instabilidade tonal, com abruptas modulações, o que favorece o uso dos modelos do Teufelsmühle ou do omnibus com variantes. Deste modo, há quem possa pensar que a escolha do padrão clássico seria muito simples, uma vez que se trata de uma expansão de dominante e assim propicia menos possibilidades de rupturas com as expectativas cadenciais. 
Diante desta colocação é possível levantar a seguinte questão: por que estudar e valorizar modelos estruturais que podem ser descritos, por vezes, como uma expansão de dominante ou então apenas como uma passagem cromática?

De fato, a elaborada polifonia que caracteriza a escrita do compositor constitui, por vezes, um fator que dificulta o reconhecimento dos padrões do Teufelsmühle ou do omnibus em sua obra. Contudo, é essencial destacar que não é apenas o uso de variantes complicadas, com omissões e substituições de acordes, como ocorre no Prelúdio Op. 28 no 9 ou na Canção $O p .74$ no 6, que torna difícil a identificação das passagens. É principalmente o modo com que o compositor tece o discurso musical que caracteriza e marca seu estilo composicional. Dito de outra forma, o que está em jogo é "como“ estes modelos cromáticos são elaborados e utilizados na obra musical.

Para responder a pergunta acima, serão retomados dois exemplos, a fim de demonstrar, de forma contextualiza na obra do compositor, alguns argumentos que respondem a esta indagação. Na passagem do Estudo Op. 25 no 11 (Cf. Ex. 57), em que é empregada a versão retrógrada do padrão clássico sem variantes, fica claro que o fator que caracteriza o uso diferenciado e extremamente sofisticado é o seu tipo de escrita e não a escolha da estrutura em si.

Outro exemplo decisivo que ilustra uma expansão da dominante principal da tonalidade encontra-se na passagem dos compassos 40 - 45 do Noturno Op. 27 no 2 (Cf. exemplos 100b, 103 e 104). Neste trecho, o uso extremamente elaborado e o papel assumido pelo Teufelsmühle na peça podem ser constatados pela complexidade das figurações melódicas, dos deslocamentos rítmicos, da troca dos diminutos geradores e das enarmonizações de notas. Tal dimensão na compreensão da integração destas estruturas ao discurso musical não poderia ser contemplada apenas pela argumentação de que se trata de um simples prolongamento da dominante, ou ainda, genericamente, de que se trata apenas de uma passagem cromática, como observado no seguinte comentário do musicólogo polonês, em referência aos compassos 41 - 45 do Op. 27 no 2: “A complexidade harmônica aqui é impressionante, assim como a audácia das associações ornamentadas com a enarmonia e ricos cromatismos" (ZIELÍNSKI, 1995, p. 455).

A observação deste tipo de cromatismo aparentemente camuflado na condução de vozes de Chopin permitiu refletir sobre algumas possibilidades de valorização destas estruturas no ato da performance. Assim, é possível considerar que este entendimento estrutural pode aclarar e fornecer respaldos tanto para o intérprete, a partir de uma 
ampliação das possibilidades de escolhas interpretativas, quanto para o estudante de música em geral, que pode entender e dominar a linguagem do compositor de forma mais aprofundada.

Sem dúvida, as variantes ocorrem com grande freqüência em sua música, no entanto, não se teve como objetivo listar ou catalogar de forma quantitativa os diferentes tipos encontrados, mas sim ilustrar e vislumbrar algumas sonoridades características e seus significados implícitos, uma vez que os modelos cromáticos ocorrem, por vezes, como um recurso expressivo e com caráter individualizado em suas obras. Talvez seja por esta razão que Seidel esclarece:

O que as transformações concretas desses modelos significam para o estilo da obra ou para a expressão na obra de arte musical, precisam ser expressamente verificadas em cada caso (SEIDEL, 1969, p. 291).

Desta forma, o estudo específico de diversas obras de Chopin revelou que os modelos cromáticos possuem, em geral, um destaque em seu discurso, que pode incluir um contraste motívico, formal, inflexões de dinâmica até o uso como um recurso que marca o momento de maior dramaticidade da peça, como ocorre no Prelúdio Op. 28 no 2, Prelúdio Op. 28 no 9, Melodia Op. 74 no 9, Noturno Op. 27 no 1 e Op. 27 no 2.

Em contrapartida, o estudo de uma significativa amostragem da obra do compositor permitiu observar algumas particularidades. Neste sentido, classificações de prenúncios e citações atribuídas por esta dissertação constituem um aspecto que fora resultado da investigação do uso do Teufelsmühle e omnibus em sua música.

Um destaque especial deve ser dispensado ao emprego da variante de Chopin, por não se limitar a um gesto harmônico particular. Sua utilização revela o intuito de surpreender, provocar um novo direcionamento cadencial e, portanto, assumem implicações musicais que englobam forma, contraste temático, dinâmica, textura, dentre outras. Esta variante configura-se numa espécie de síntese dos modelos do Teufelsmühle ou omnibus, cujas relações foram descritas no terceiro capítulo desta dissertação, e que reforçam a importância e significado desta sonoridade para Chopin. 
Outro fato observado diz respeito ao momento formal em que os modelos cromáticos usualmente estão inseridos, geralmente em transições, especialmente aquelas que conduzem à volta do tema inicial da peça ${ }^{4}$.

Foram encontradas também outras particularidades que se referem especificamente às disposições das linhas constituintes do Teufelsmühle ou omnibus. Pode-se dizer que a consciência dos aspectos horizontais advindos da visão americana promoveu, num nível mais aprofundado, a compreensão da escrita de Chopin, ou seja, a maneira como ele faz uso destas estruturas em sua práxis composicional. Assim, foi o conhecimento da condução de vozes que possibilitou entender a forma com que o mestre polonês tece o discurso musical, seja em uma passagem classificada como omnibus ou Teufelsmühle.

Ocorre que existe uma preferência do compositor em manter uma das notas do pedal no plano mais agudo da tessitura de forma estática, tal como demonstrado no Noturno Op. 55 no 2, no Prelúdio Op. 28 no 2 e na Polonaise Op. 26 no 1, ou muito ornamentada por meio de figurações melódicas, como demonstrado no Estudo Op. 25 no 11, na Fantasia Op. 49, no Prelúdio Op. 28 no 8 ou no Noturno Op. 27 no 2. Além disso, é freqüente encontrar praticamente todas as notas que compõem os modelos cromáticos de forma distribuída na mão esquerda, o que implica em uma textura que aparenta ser um acompanhamento, quando de fato, trata-se de uma sofisticada escrita polifônica (Cf. exemplos 50, 63, 64, 83 e 104).

Em suma, os modelos cromáticos em Chopin não representam algo que rompe um padrão, mas é um pressuposto para uma nova "roupagem" por meio de seu estilo pessoal. O fato do compositor não utilizá-los como um clichê, ou seja, como algo convencional, exclui um emprego rígido e previsível. Com isso, o mestre polonês mantém a essência do Teufelsmühle e omnibus em sua música e ao mesmo tempo transcende o mecanismo de forma original e criativa. Neste sentido, as considerações sobre as sequências cromáticas, encontradas nas palavras Dittrich , traduzem este pensamento e confirmam o posicionamento desta pesquisa: "compor inclui, nesta época que tratamos aqui, ou seja, do final do século XVIII e início do XIX, a utilização, a transformação e a transfiguração de fórmulas conhecidas [...]" (DITTRICH, 2007, p. 107).

\footnotetext{
${ }^{4}$ Dentre alguns exemplos que ilustram esta última especificação encontram-se os Improvisos Op. 51 no 3 (comp. 75 - 76) e Op. 66 (comps. 20 - 25); o Primeiro Scherzo (comps. 117 - 125); as Mazurkas Op. 33 no 4 (comps. 62 - 65) e Op. 68 no 4 (Cf. Ex. 92); e os Noturnos Op. 55 no 1 (Cf. Ex. 69), Op. 27 no 1 (Cf. Ex. 96) e Op. 27 กㄴ 2 (Cf. Ex. 100b).
} 


\section{REFERÊNCIAS BIBLIOGRÁFICAS}

ALDWELL, Edward \& SCHACHTER, Carl. Harmony and Voice Leading. Philadelphia: Harcourt Brace Jovanovich College Publishers, 1989.

BARTEL, Dietrich. Musica Poetica: Musical-Rhetorical Figures in German Baroque Music. London: University of Nebraska Press, 1997.

BENWARD, Bruce. Music in Theory and Practice, 2a. ed. W. C. Brown, 1981.

BERRY, Wallace. Musical Structure and Performance. New York: Yale University Press, 1989.

BROWN, Clive. Classical \& Romantic Performance Practice (1700-1900). New York: Oxford University Press, 1999.

CONE, Edward. The pianist as critic. In: RINK, John (Org.) The Practice of Performance: Studies in Musical Interpretation. Cambridge: Cambridge University Press, 2005, p. 241-253. Ambiguity and reinterpretation in Chopin. In: RINK, John (Org.) Chopin studies 2. Cambridge: Cambridge University Press, 2006, p. 140 - 160.

COOK, Nicholas. Entre o processo e o produto: música e/enquanto performance. Per Musi. Trad. Fausto Borém. Belo Horizonte: no 14, 2006, p. 05-22.

DAMSCHRODER, David. Thinking about Harmony: Historical Perspectives on Analysis. Cambridge: Cambridge University Press, 2008.

DAMSCHRODER, David; RUSSELL, David Williams. Music Theory from Zarlino to Schenker: A Bibliography and Guide. Harmonologia no 4. New York: Joel Lester Series Editor, 1990.

DITTRICH, Marie-Agnes. Teufelsmühle und Omnibus. Zeitschrift der Gesellschaft fur Musiktheorie, Vol. 4 no 2, 2007, p. 107-121.

DUNSBY, Jonathan; WITTALL, Arnold. Music analysis in theory and practice. London: Faber \& Faber, 1988.

EIGELDINGER, Jean-Jacques. Chopin pianist and teacher. Trad. Naomi Shahet. Cambridge: Cambridge University Press, 1991.

FÖRSTER, Emmanuel Aloys. Anleitung zum Generalbass. Wien: Johann Träg, 1805.

FRANCOLÍ, Miguel A. Roig. Harmony in Context. New York: McGraw-Hill, 2003.

GAULDIN, Robert. The Theory and Practice of Chromatic Wedge Progressions in Romantic Music. Music Theory Spectrum, Vol. 26, No. 1, 2004, p. 1-22. 
GREEN, Douglas. Form in Tonal Music. New York: Harcourt Brace Jovanovich College Publishers, 1993.

HUNEKER, James. Chopin: the man and his music. New York: Dover Publication, 1966.

KOPP, David. Chromatic Transformations in Nineteenth-Century Music. Cambridge: Cambridge University Press, 2002.

KOSTKA, Stefan; PAYNE, Dorothy. Tonal Harmony. 5a ed. New York: McGraw-Hill, 2004.

LESTER, Joel. Performance and analysis: interaction and interpretation. In: RINK, John (Org.) The Practice of Performance: Studies in Musical Interpretation. Cambridge: Cambridge University Press, 2005, p. 197-216.

MESSIAEN, Olivier. The Technique of my Musical Language. Paris: Alphonse Leduc, s/d.

MEYER, Leonard B. Emotion and Meaning in Music. Chicago: Chicago University Press, 1956. Explaining Music: Essays and Explorations. California: University of California Press, 1973.

NARMOUR, Eugene. Melodic structuring of harmonic dissonance: a method for analyzing Chopin's contribution to the development of harmony. In: SAMSON, Rink (Ed.) Chopin Studies. Cambridge: Cambrigde University Press, 1991 p. 77 - 114.

OLIVEIRA, Willy Corrêa de. "Transcrições das aulas do curso de Linguagem e Estruturação Musicais". In: ULBANERE, Alexandre. Willy Corrêa de Oliveira: por um ouvir materialista histórico (Anexos). Dissertação de mestrado, Universidade Estadual Paulista Júlio de Mesquita Filho. São Paulo, 2005.

PISTON, Walter. Harmony. Revised and Expanded by Mark Devoto. London: Victor Gollancz Ltd, 1987.

RIMSKY-KORSAKOV, Nikolai. Traité D’Harmonie: Théorique et pratique. Trad. Félix Dorfmann.

Paris: Alphonse Leduc, 1978.

RINK, John. Chopin: The Piano Concertos. Cambridge: Cambridge University Press, 1997.

ROGERS, Michael R. Teaching Approaches in Music Theory - An Overview of Pedagogical

Philosophies. 2a ed. Carbondale: Southern Illinois University Press, 2004.

ROSEN, Charles. A Geração Romântica. Trad. Eduardo Seincman. São Paulo: Editora da Universidade de São Paulo, 2000.

ROSENBLUM, Sandra. Performance Practices in Classic Piano Music. Bloomington: Indiana University Press, 1988. 
ROTHSTEIN, William. Analysis and the act of performance. In: RINK, John (Org.) The Practice of Performance: Studies in Musical Interpretation. Cambridge: Cambridge University Press, 2005, p. 217-240.

SAMSON, Jim (Edited). Companion to Chopin. Cambridge: Cambridge University Press, 2000. . The Music of Chopin. Oxford: Clarendon Press, 1994.

. Chopin: The four ballades. Nova York: Cambridge University Press, 1992.

SCHACHTER, Carl. Chopin's Fantasy, Op. 49: the two-key scheme. In: SAMSON, Rink (Ed.) Chopin Studies. Cambridge: Cambrigde University Press, 1991 p. 221 - 253.

SCHENKER, Heinrich. Harmony. Chicago: University of Chicago Press, 1954.

SCHOENBERG, Arnold. Structural Functions of Harmony. 2nd ed., rev. London: Ernest Benn, 1969. . Funções Estruturais da Harmonia. Trad. Eduardo Seincman. São Paulo: Via Lettera, 2004. . Harmonia. Trad. Marden Maluf. São Paulo: Editora da Unesp, 1999.

SEIDEL, Elmar. Ein chromatisches Harmonisierungs-Modell in Schuberts Winterreise. Musikwissenschaft, vol. 26 no. 4, 1969.

. Über den Zusammenhang zwischen sogenannten Teufelsmuhle und dem 2. Modus mit begrenster transponierbarkeit in Liszts harmonic, in Referate des europäischen Liszt_Symposions, Eisenstadt 1978 (= Liszt-Studien 2), hg. von Serge Gut, München, Salzburg: Katzbichler, 1981.

SUTCLIFFE, Dean. Chopin's Counterpoint: The Largo from the Cello Sonata, Opus 65. The Musical Quartely, Vol. 83, No. 1, 1999, p. 114-133.

TELESCO, Paula. Enharmonicism in theory and Practice in 18th Century Music. Ph.D. dissertation, Ohio State University, 1993.

. Enharmonicism and the Omnibus Progression in Classical-Era Music. Music Theory Spectrum, Vol. 20, No. 2, 1998, p. 242-279.

Reviewed work(s): The Omnibus Idea by Victor Fell Yellin. Music Theory Spectrum, Vol. 23, No. 1, 2001, p. 129-136.

TOMASZEWSKI, Mieczyslaw. Fryderyk Chopin: Nocturne in D flat major, Op. $27 \mathrm{nr}$ 2. Source commentary. Warsaw: The Fryderyk Chopin Instytut, 2007.

TOVEY, Donald Francis. A Companion to Beethoven`s Pianoforte Sonatas. London: The Associated Board of the Royal School of Music, 1998.

VOGLER, Georg Joseph. Tonwissenschaft und Tonsezkunst. Hildesheim: Georg Olms Verlag, 1970. YELLIN, Victor Fell. The Omnibus Idea. Warren, Michigan: Harmonie Park Press, 1998. 
WASON, W. Robert. Viennese Harmonic Theory from Albrechtsberger to Schenker and Schoenberg. New York: University of Rochester Press, 1985.

ZIEHN, Bernhard. Canonical Studies: A New Technique in Composition. Ronald Stevenson (editor). London: Kahn \& Averill, 1976.

ZIELÍNSKI, Tadeusz. Frédéric Chopin. Trad. Marie Bouvard e Laurence Dyèvre. França: Fayard, 1995.

\section{DISCOGRAFIA}

ARRAU, Claudio. Chopin: The Complete Nocturnes/ The Complete Impromptus. CD $4563362-$ 6. Philips, 1997.

ASHKENAZY, Vladimir. Chopin: The Piano Works. CD 443738-2. Decca, 1995.

FREIRE, Nelson. Chopin: The Nocturnes. CD 4782182. Decca, 2009.

GODOWSKY, Leopold. Great Pianists of the 20th Century (Vol. 38). CD 456805-2. Philips/EMI, 1999. HARASIEWICZ, Adam. Frédéric Chopin: Die Klavierkonzerte und Klavierwerke Solo (Cd. 7). CD 4428746. Decca, 2007.

HOFMANN, Josef. The Complete Josef Hofmann: Solo Recordings, 1935-48 (Vol. 5). CD 52004-

2. Marston Records, 1997.

NOVAES, Guiomar. Guiomar Novaes Plays Chopin. CD 1062238. Vox, 1995.

PIRES, Maria João. Chopin: The Nocturnes. CD 447096-2. Deutsche Grammophon, 1995. POLLINI, Maurizio. Chopin: Complete Nocturnes. CD 4775718-4. Deutsche Grammophon, 2005. VÁSÁRY, Tamás. Chopin Piano Works. CD 4693502. Deutsche Grammophon, 2002. 


\section{Introdução geral}

\section{p. 2}

"Dass ein verbindlicher Terminus bisher fehlt, erschwert den Überblick über den augenblicklichen Diskussionsstand, sofern davon überhaupt die Rede sein Kann [...] (DITTRICH, 2007, p. 108).

"o fato de que até o momento não se dispõe de um termo obrigatório [ou seja, uma terminologia consolidada para este modelo] dificulta uma visão geral sobre o estado atual da discussão [...]" (DITTRICH, 2007, p. 108).

\section{Capítulo 1}

p. 16

Die Teufelsmühle konnte auch mit einem der beiden anderen Akkorde, also mit dem verminderten Septakkord oder mit dem Mollquartsextakkord begonnen werden. Wurden das Bauprinzip der Akkordfolge dadurch nicht angetastet, d. h. folgte auf den verminderten Septakkord der Mollquartsextakkord, auf diesen der Dominantseptakkord usw. [...] (SEIDEL, 1981, p. 173).

O Teufelsmühle poderia também ter começado com um dos outros dois acordes, ou seja, com o acorde de sétima diminuta ou com o menor com quarta e sexta. Não haveria nada a se objetar a isso, se não houver mudanças no princípio de construção da seqüência dos acordes, isto é, se depois do acorde de sétima diminuta se seguir o acorde menor com quarta e sexta e, depois desse, o acorde de sétima de dominante, etc. [...] (SEIDEL, 1981, p. 173).

p. 25

Zwischen Teufelsmühle (Version A) und 2. Modus besteht also nicht nur irgendein Zusammenhang, wie wir vermuteten, sondern - mehr noch - Identität [...] Anders ausgedrückt: : erklingt die Teufelsmühle (immer in der Version A), erklingt gleichzeitig über dem chromatisch steigenden oder fallenden $\mathrm{Ba} \beta$ der 2 . Modus. (SEIDEL, 1981, p. 174). 
Entre o Teufelsmühle versão $\mathrm{A}$ e o segundo modo, portanto, existe não apenas uma relação qualquer como supúnhamos, mas algo além: há [uma relação de] identidade [...] Dito de outra forma: ao ressoar o Teufelsmühle (sempre na versão A), ressoa ao mesmo tempo o segundo modo sobre o baixo cromático ascendente ou descendente (SEIDEL, 1981, p. 174).

[...] bilden zwei Gruppen der Teufelsmühle (Version A) das harmonische Gerüst der ersten vier Takte (T. 25 - 28) unseres Beispiels. Jede Gruppe beginnt mit einem verminderten Septakkord. Ein Mollquartsextakkord folgt. Der dritte Akkord ist in beiden Fällen als übermäßiger Quintsextakkord notiert [...] Liszt hätte ebenso einen Dominantseptakkord [...], des notieren können, wie er es übrigens teilweise an der entsprechenden Stelle der ersten Fassung dieses Stückes getan hat. Eine dritte Gruppe der Teufelsmühle wird in Takt 29 gerade noch begonnen, nach dem 1. Akkord, dem verminderten Septakkord e- ais - cis - g, aber abgebrochen (SEIDEL, 1981, p.173).

[...] dois grupos do Teufelsmühle (versão A) constituem a estrutura harmônica dos primeiros quatro compassos de nosso exemplo (compassos 25 a 28). Cada grupo começa com um acorde de sétima diminuta. Segue-se um acorde menor com quarta e sexta. O terceiro acorde é, em ambos os casos, escrito como um acorde de sexta aumentada [...] Liszt poderia igualmente ter escrito [como] um acorde de sétima de dominante [...], tal como, diga-se de passagem, ele $\mathrm{o}$ fez em parte na passagem correspondente da primeira versão dessa peça. Um terceiro grupo do Teufelsmühle começa no compasso 29, mas depois do primeiro acorde, o acorde de sétima diminuta (Mi Lá\# Dó\# Sol), é interrompido (SEIDEL, 1981, p.173).

Durch die Figuration treten teilweise fremde Töne zu den sechs Akkorden der Teufelsmühle. Hört man genauer hin, so etdeckt man, da $\beta$ die ab Takt 26 nachschlagenden 5. und 6. Bzw. 2. und 3. Achtel in der linken Hand zusammengehören. Sie bilden eine Skala. (Beisp. 8) Es ist eine Skala besonderer Art, nicht sieben -, sondern achtstufig. Ihr mangelt die reine Quinte, dafür bildet der Kleinterzzirkel ihr Gerüst (SEIDEL, 1981, p. 174).

Por meio da figuração entram sons estranhos aos seis acordes do Teufelsmühle. Se ouvirmos mais atentamente, descobriremos que a quinta e sexta colcheias tocadas a partir do compasso 26 , assim como a segunda e a terceira colcheias da mão esquerda pertencem ao mesmo grupo. Elas constituem uma escala (Ex. 8). Trata-se de uma escala de um tipo especial, que contém não sete, mas oito sons. Nela falta a quinta justa, por isso o círculo de terças menores constitui a sua estrutura (SEIDEL, 1981, p. 174). 
Weitere Formen des Satzmodells, in denen es allerdings oft nur noch schwer zu erkennen ist, ergeben sich durch die in der Praxis sehr häufige Kombination der Versionen A und B der Teufelsmühle, durch Modifikation oder Auslassungen einzelner Akkorde oder duch Sprünge in eine der Transpositionen (DITTRICH, 2007, p. 112).

Outras formas desse modelo, que são mais difíceis de reconhecer, são derivadas da combinação - muito freqüente na prática composicional - das versões A e B do Teufelsmühle, bem como da modificação [do padrão], omissão de alguns acordes, ou saltos para uma das transposições (DITTRICH, 2007, p. 112).

Harmonisch ähnlich angelegt wie die Takte 38 bis 40 der Etüde ist eine Episode in der sogenannten Dante - Sonate (Après une lecture de Dante, Annés de pèlerinage II, $7 \backslash 2$. Version 1849, Takt 89 - 95). Nur sind hier die Mollquartsextakkorde durch Molldreiklänge in der Grundstellung ausgetauscht worden. Im Unterschied zum vorigen Beispiel steht hier der ganze Satz, auch die Partie der rechten Hand, im 2. Modus [...] (SEIDEL, 1981, p. 175).

Um episódio da chamada Sonata Dante (Après une lecture de Dante, Anos de Peregrinação II, 2a versão 1849, compassos 89-95) é construído de maneira harmonicamente similar à passagem dos compassos 38 - 40 do [Segundo] Estudo. Mas aqui, os acordes menores com quarta e sexta foram intercambiados por tríades menores na posição fundamental. [...] inclusive a parte da mão direita está no segundo modo [...](SEIDEL, 1981, p. 175).

\section{p. 34}

Anders als Version A der Teufelsmühle enthält Version B in keiner ihrer Stimmen den 2. Modus, sondern nur die chromatische Tonleiter. [...] Doch selbst Version B läßt sich durch einen Kleinen Kniff in eine Akkordfolge des 2. Modus verwandeln. Man braucht blo $\beta$ alle Mollquartsextakkorde auszulassen [...] (SEIDEL, 1981, p. 175).

Diferentemente da versão $A$ do Teufelsmühle, a versão B não contém o segundo modo em nenhuma de suas vozes, mas apenas a escala cromática. [...] Contudo, mesmo a versão B pode ser convertida em uma sequência de acordes do segundo modo por meio de um pequeno truque. É preciso apenas omitir todos os acordes menores com quarta e sexta [...] (SEIDEL, 1981, p. 175). 


\section{Capítulo 2}

\section{p. 38}

"[...] was simply to find a plain and easy way to explain the mysteries of chromatic harmony to graduate students at New York University" (YELLIN, xi, 1998).

" [...] era simplesmente achar um modo claro e fácil de explicar os mistérios da harmonia cromática para os estudantes de pós-graduação da Universidade de Nova lorque" (YELLIN, xi, 1998).

"The more the omnibus Idea was employed in actual music, the less it was explained or even identified in the classroom" (YELLIN, 1998, p. 7).

"Quanto mais a ideia omnibus era empregada na música [...], menos ela era explicada ou mesmo identificada em sala de aula" (YELLIN, 1998, p. 7).

In its classic form, the omnibus progression may be described as a chain of five chords beginning with (1), a dominant seventh in the first inversion, the root in the soprano. While the inner voices, tenor and alto forming the interval of the minor third, remain stable as pedals or double pedal, the two outer voices, soprano and bass, expand by contrary motion in four chromatic steps. The resulting chords, (2), (3), (4), and (5), are not as easily named. But the central chord (3) can be recognized as a minor six-four chord bracketed by chorus (2) and (4), each taken as either a dominant seventh or augmented sixth. The series ends with chord (5), the same harmony as chord (1), but in root position, the third in the soprano (YELLIN, 1998, p. 3).

Em sua forma clássica, a progressão omnibus pode ser descrita como um encadeamento de cinco acordes começando com o (1), uma dominante com sétima em primeira inversão com a fundamental no soprano. Enquanto as vozes internas, tenor e contralto, formando um intervalo de terça menor, permanecem estáveis como notas pedais ou duplo pedal, as duas vozes extremas, soprano e baixo, expandem-se por movimento contrário em quatro passos cromáticos. Os acordes resultantes (2) (3) (4) e (5) não são nomeados tão facilmente. Mas o acorde central (3) pode ser reconhecido como um acorde menor com quarta e sexta posicionado entre os acordes (2) e (4), os quais podem ser considerados seja como um acorde de dominante com sétima ou de sexta aumentada. A série termina com o acorde (5), a mesma harmonia do acorde (1), mas em posição fundamental e com a terça no soprano. (YELLIN, 1998, p. 3) 


\section{p. 41 nota 10}

"[...] is the best theoretical demonstration of the principle upon which the omnibus idea is based" (YELLIN, 1998, p. 9).

"[...] é a melhor demonstração teórica do princípio sobre o qual a idéia omnibus é baseada" (YELLIN, 1998, p. 9).

" [...] taken a segment of Vogler's chromatic scale harmonization and modified it so that the progression results in the exchange of components of a dominant seventh chord - Yellin's "classical omnibus" (WASON, 1985, p. 57).

" [...] tomou um segmento da harmonização da escala cromática do Vogler e a modificou de forma que a progressão resulta na troca de componentes de um acorde de dominante com sétima - o “omnibus clássico" de Yellin" (WASON, 1985, p. 57).

\section{p. 45}

Probably the most fascinating characteristic of the omnibus is its ability to "mutate" (TELESCO, 1998, p. 129).

Provavelmente a característica mais fascinante do omnibus é a sua habilidade de mutação (TELESCO, 1998, p. 129).

[...] by perceiving a new (minor third/major sixth) double pedal at the termination of the progression, a new series may be inaugurated. As the pedals $\mathrm{c}$ and eb, the fifth and the minor seventh of chord (5) of the original series are abandoned, new pedals, $c$ and a, the fifth and third, transform chord (5) into chord (2) of the new series. [...] Similar mutations may be employed to extend the bass indefinitely (YELLIN, 1998, p. 3).

[...] uma nova série pode ser iniciada ao se constatar um novo pedal duplo (terça menor/sexta maior) na terminação da progressão. Quando as notas Dó e Mib do pedal, quinta e a sétima menor do acorde (5) da série original são abandonados, novas notas pedais, Dó e Lá, a quinta e a terça transformam o acorde (5) no acorde (2) da nova série. [...] Mutações similares podem ser empregadas para prolongar o baixo indefinidamente (YELLIN, 1998, p. 3). 
The framing dominants make it clear that the intervening chords participate in a prolongation of $\mathrm{V}$, even though they may temporarily suggest deeper structural functions. But if one of the framing dominants is removed, or becomes part of a separate voice exchange, the progression loses its tonal anchor. This happens when several omnibus progressions a minor third apart are strung together [...] A complete cycle, which traverses an entire chromatic octave, requires four overlapped statements. And since the notes held as common tones throughout one complete cycle comprise a diminished seventh chord, there are only three possible cycles (TELESCO, 1998, p. 259-260).

As dominantes que estão nas duas pontas [desta progressão] tornam claro que os acordes inseridos [na mesma] participam de um prolongamento do $\mathrm{V}$, mesmo que temporariamente eles possam sugerir funções estruturais mais profundas. Mas se uma das dominantes das pontas for removida ou se tornar parte de uma troca de vozes à parte, a progressão perde o seu ancoramento tonal. Isso ocorre quando diversas progressões omnibus em relação de terça menor são mantidas juntas [...] Um ciclo completo, que atravesse uma oitava cromática inteira, requer quatro dessas sobreposições. E uma vez que as notas mantidas como sons comuns, ao longo de um ciclo completo, compreendem um acorde de sétima diminuta, [deduz-se que] há apenas três ciclos possíveis (TELESCO, 1998, p. 259-260).

[...] in practice the omnibus was not a single immutable progression, but a family of progressions, meaning its presence in a passage may not be immediately obvious (TELESCO, 1998, p. 244).

[...] na prática, o omnibus não foi uma progressão imutável única, mas uma família de progressões, o que significa que sua presença em uma passagem pode não ser imediatamente óbvia (TELESCO, 1998, p. 244).

"Kaum weniger verwirrend als die Vielzahl der Varianten des Modells ist seine Einordnung in der einschlägigen Literatur" (DITTRICH, 2007, p. 114).

"Não menos confusa do que esse grande número de variantes dos modelos é também a sua ordenação na bibliografia principal” (DITTRICH, 2007, p. 114).

\section{p. 55}

"[...] because of the admixture of triads, dominant sevenths, and diminished sevenths $[\ldots]^{\prime \prime}($ YELLIN, 1998, p. 15-16). 
sétima [...]" (YELLIN, 1998, p. 15-16).

\section{p. 57}

[...] is part of a larger problem in terms of consistency of identification, which I found at times confusing and frustrating. Sometimes Yellin underlays a musical example with the models omnibus and brackets the note or notes of the model that are missing from the actual passage instead of indicating the substitution of a diminished seventh [...] (TELESCO, 2001, p. 132).

[...] é parte de um problema mais amplo em termos de consistência da identificação, que às vezes eu acho confusa e frustrante. Em alguns momentos Yellin sustenta um exemplo musical com os modelos omnibus e coloca entre colchetes a nota ou notas do modelo que estão faltando na passagem atual ao invés de indicar a substituição de um acorde diminuto [...] (TELESCO, 2001, p. 132).

The sole difference between the two progressions is that wherever the omnibus contains a dominant 4-2, the Vogler progression contains a diminished seventh chord [...] (TELESCO, 2001, 132).

A única diferença entre as duas progressões [de Vogler e o padrão clássico] é que onde quer que o omnibus contenha uma dominante com sétima no baixo [acorde (4) do padrão clássico], a progressão de Vogler contém um diminuto com sétima [...] (TELESCO, 2001, 132).

p. 59

Noch dazu kommen natürlich leittönige Akkorde um einen Durchgangs-Quartsextakkord (also die bei Thorau so genannte Periphrase der Wechseldominante) auch in ganz normalen Kadenzen, vor allem in Moll, häufig vor. Die Bezeichnung "small omnibus" für derartige Kadenzfragmente etwa bei Telesco (259) scheint deshalb nicht zwingend. (DITTRICH, 2007, p. 115).

Naturalmente, acordes de sensíveis para acordes menores com quarta e sexta de passagem (que Thorau chama de perífrase de troca de vozes na dominante), ocorrem também em cadências normais, sobretudo em cadências em menor. Por isso, a designação small omnibus para tais fragmentos de cadência, como vemos, por exemplo, em Telesco (página 259), parece algo não convincente. (DITTRICH, 2007, p. 115). 


\section{Capítulo 3}

\section{p. 67}

Es versteht sich von selbst, dass das Satzmodell $>$ Teufelsmühle $<$ bzw. $>$ Omnibus< am leichtesten ins Ohr fällt, wenn seine Harmoniefolgen nicht durch komplizierte Stimmführung und Rhythmik verschleiert werden und die Stimmung die Haupttonart und ihre nahen Verwandten bevorzugt. Je mehr sich einerseits im 19. Jahrhundert all diese Voraussetzungen ändern und je mehr die >Teufelsmühle< ihrerseits varriert werden muss, um nicht zum Klischee zu erstarren, desto schwerer wird es, sie als markiert zu empfinden - oder Analysen nachzuvollziehen, die sie oden den >Omnibus< aufzuspüren glauben. (DITTRICH, 2007, p. 119).

É evidente que o modelo do Teufelsmühle ou omnibus é auditivamente mais perceptível quando suas sequências harmônicas não são dissimuladas por meio de uma condução de vozes e rítmica complicadas, e quando a atmosfera favorece a tonalidade principal e aquelas mais próximas a ela. No século XIX, quanto mais todos esses pressupostos mudam e quanto mais o Teufelsmühle, por sua vez, deve ser variado para não se enrijecer em clichê, tanto mais difícil se torna percebê-lo como evidente - ou realizar análises que acreditam detectar a ele ou ao omnibus (DITTRICH, 2007, p. 119).

[...] the music of every well-known composer suffers from the effects of over-exposure, but Chopin's case is an exacerbated one. Familiarity has dulled our appreciation - has sometimes even blocked our recognition - of one of the primary characteristics of his style: the ambiguity that permeates every level of his musical thought (CONE, 2006, p. 140).

[...] a música de todos os compositores muito conhecidos sofre os efeitos da superexposição, mas o caso de Chopin é exacerbado. A familiaridade embotou nossa apreciação (algumas vezes até bloqueou nossa recognição) de uma das características primárias de seu estilo: a ambigüidade que permeia todos os níveis de seu pensamento musical (CONE, 2006, p. 140). 


\section{Capítulo 4}

p. 106

Von dem Bachschen Beispiel dürfen wir sagen, daß hier die Anwendung des harmonischen Modells durch eine Ausdrucksfigur bestimmt ist, nämlich die Pathopoiia. Das ist bekanntlich eine Figur, durch deren Anwendung ein musikalischer Satz oder eine bestimmte Satzstelle pathetisch hervorgehoben wird. Sie kommt in der Anordnung der chromatischen Töne sowohl auf- wie absteigend vor. Nur absteigend ist sie mit dem Ausdruck des Schmerzes, der Trauer, des Leides (Lamento) verbunden. Aber auch aufsteigend bleibt sie eine pathetische Ausdrucksfigur (SEIDEL, 1969, p. 291).

Do exemplo de J. S. Bach [referindo-se a Paixão Segundo São Mateus], podemos dizer que aqui a utilização do modelo harmônico é influenciada por uma figura de expressão, a saber: a pathopoiia. Como é sabido, esta é uma figura por meio de cuja aplicação uma frase musical ou uma determinada passagem de uma frase é acentuada pateticamente. Ela [a pathopoiia] ocorre tanto ascendente como descendentemente na disposição dos sons cromáticos. Somente descendentemente ela está ligada à expressão da dor, da tristeza, do sofrimento (Lamento). Porém, também ascendentemente ela permanece como uma figura de expressão patética (SEIDEL, 1969, p. 291).

p. 107

"[...] association of sadness and suffering with the slower tempi that tend to accompany the chromaticism prevalent in the minor mode" (MEYER apud Telesco 1998, p. 253).

"[...] associação de tristeza e sofrimento com os tempos lentos que tendem a acompanhar o cromatismo predominante no modo menor" (MEYER apud Telesco 1998, p. 253).

p. 113

The function of the dissonant chord (bar 143) that creates the 'deception' is not immediately clear. Indeed only when we approach the second cycle shall we see that it results from the chromatic inflection of the ${ }^{6}{ }^{6}$ that arrived in bar 141 (SCHACHTER, 1991, p. 243).

A função do acorde dissonante (compasso 143) que cria um "efeito deceptivo" não está imediatamente clara. Na verdade, somente quando atingimos o segundo ciclo nós vemos que ele resulta da inflexão cromática do $\|^{6}$ que apareceu no compasso 141 (SCHACHTER, 1991, p. 243). 
[...] our present-day desire to demonstrate tonal unity wherever possible prompts us to describe the structure as the prolongation of a single harmony, whose function must not be in doubt. As a result, we do not hear the music as I believe it was intended to be heard. That is why I have resorted to what I call 'intentional analysis', which seeks to ascertain, as far as possible, how the composer wished us to hear his music. I suggest that Chopin was here being deliberately ambiguous, and that a convincing analysis of the passage must reveal that intention (CONE, 2006, p. 141).

[...] nosso desejo atual de demonstrar unidade tonal sempre que possível nos leva a descrever a estrutura como um prolongamento de uma única harmonia, cuja função não se deve estar em dúvida. Como resultado, nós não ouvimos a música como eu acredito que ela foi planejada para ser ouvida. É por isso que eu tenho recorrido ao que chamo de "análise intencional", que procura evidenciar, tanto quanto possível, como o compositor gostaria que ouvíssemos sua música. Eu sugiro que Chopin estava sendo deliberadamente ambíguo aqui [referindo-se a passagem dos compassos $1-8$ da Quarta Balada Op. 52] e que uma análise convincente desta passagem deve revelar essa intenção (CONE, 2006, p. 141).

p. 120

"[...] mere "chromaticism" [...] intricate figurations, sometimes with great velocity" (YELLIN, 1998, p. 52).

"[...] mero "cromatismo" [...] figurações complexas, às vezes com grande velocidade" (YELLIN, 1998, p. 52).

\section{p. 124}

"In der instrumentalen Musik wird bei Beethoven die pathetische Wirkung des chromatischen Harmonisierungs-Modells besonders an Höhepunkten des Verlaufes eines ganzen Satzes erkennbar [...].” (SEIDEL, 1969, p. 292).

"Na música instrumental de Beethoven, o efeito patético do modelo de harmonização cromático torna-se reconhecível especialmente nos pontos culminantes do decurso do movimento inteiro [...]" (SEIDEL, 1969, p. 292). 
[...] the flat D major Nocturne is one of those in which the musical narrative proceeds according to distinct principles. Whilst the threefold appearance of the main theme could suggest rondo form, the character of the work (lento sostenuto) precludes such a reading. The unique, atypical shape of the Nocturne: $n A 1 \quad B 1 \quad B 2 \quad B 3$ u A2 B4 $B 5 \times A 3 B 6$ y $C 1 C 2$ z can be defined as an 'anchor-condensation' patterns, the 'anchoring' element of the narrative being the theme $A$, which forms a constant point of reference for the work (TOMASZEWSKI, 2007, p. 20).

[...] o Noturno em Réb maior é um daqueles em que a narrativa musical procede de acordo com princípios distintos. Ainda que a tripla aparição do tema principal pudesse sugerir a forma rondó, o caráter da obra (lento sostenuto) impossibilita este tipo de interpretação. A forma única e pouco comum do Noturno, nA1 B1 B2 $B 3$ u A2 B4 B5 x A3 B6 y $C 1 C 2 z$, pode ser definida como modelos "âncora-condensadores", com o tema A sendo o elemento âncora da narrativa, formando um ponto constante de referência para a obra (TOMASZEWSKI, 2007, p. 20).

p. 127

"...] the second time, pianíssimo - assisted by the second (una corda) pedal, which is perfectly justified by character and the modulation which prepares it [...]" (EIGELDINGER, 1991, p. 80).

[...] a segunda vez, pianíssimo [referindo-se à segunda entrada do tema no compasso 26] assistida pelo segundo (uma corda) pedal, a qual é perfeitamente justificada pelo caráter e a modulação que a prepara [...]" (EIGELDINGER, 1991, p. 80).

\section{p. 134}

[...] even if the omnibus progression no longer carried specific lament connotations for classical-era composers, it still carried much of the rhetorical and dramatic weight from its origins in the passacaglia basses and lament arias, and would therefore be a felicitous choice for the dramatic climax of a composition (TELESCO, 1998, p. 274).

[...] mesmo se a progressão omnibus não mais contivesse conotações específicas do lamento para os compositores da era clássica, ela ainda continha muito do peso retórico e dramático de sua origem nos 
baixos de Passaglia e Arias de lamento, e portanto, seria uma escolha apropriada para o clímax dramático de uma composição (TELESCO, 1998, p. 274).

\section{Considerações finais}

p. 136

[...] an exotically colorful, chromatic, yet utilitarian progression to take the music from one key to another, close or distant, providing a wild enharmonic ride along the way (TELESCO, 1998, p. 276).

[...] uma progressão exoticamente colorida, cromática, mas com utilidade de levar a música de uma tonalidade a outra, próxima ou distante, fornecendo um trajeto enarmônico extravagante pelo caminho (TELESCO, 1998, p. 276).

\section{p. 138}

"a slight variation of a standard chromatic progression known as the omnibus [...] the omnibus in example $27.15 d$ is simply a chromatic linear prolongation of an FM $V^{7}$ chord" (FRANCOLI, 2003, p. 804)

"uma ligeira variação de uma progressão cromática padrão conhecida como omnibus. [...] "o omnibus no exemplo 27.15d é simplesmente um prolongamento linear cromático de um acorde de Fá maior com sétima“" (FRANCOLÍ, 2003, p. 804).

\section{p. 139}

In fact, it is difficult to find an eighteenth-century omnibus passage that is simply that: a straightforward dominant prolongation, without any overlapping statements (TELESCO, 1998, p. 275).

De fato, é difícil encontrar uma passagem omnibus do século XVIII que seja simplesmente isso: um prolongamento direto de dominante, sem nenhuma apresentação sobreposta [em outras palavras, sem nenhuma mutação do omnibus] (TELESCO, 1998, p. 275). 
"eighteenth-century examples are as a rule more tonally ambiguous than those of the nineteenth-century, where classic omnibuses are relatively easy to find" (TELESCO, 1998, p. 275).

"os exemplos do século dezoito funcionam, via de regra, de uma maneira tonalmente mais ambígua do que aqueles do século XIX, onde os omnibus clássicos são relativamente mais fáceis de serem encontrados" (TELESCO, 1998, p. 275).

\section{p. 140}

While some of the examples I have examined show omnibus progressions in developmental or transitional passages - as one would expect for harmony of such ambiguity and instability composers also use them in what would normally be harmonically stable sections of music. This creates an element of surprise, allowing for excursions into remote keys in the most unexpected places [...] (TELESCO, 1998, p. 272).

Enquanto alguns dos exemplos que eu examinei mostram as progressões omnibus em passagens de desenvolvimento e transição, como se poderia esperar para uma harmonia de tal ambigüidade e instabilidade - os compositores também as usam naquele que poderia ser normalmente seções estáveis da música. Isto cria um elemento de surpresa, permitindo incursões em tonalidades remotas nos lugares mais inesperados [Cf. Ex. X] (TELESCO, 1998, p. 272).

p. 141

"La complexité harmonique est ici frappante, de même que l'audace des associations agrémentées de l'enharmonie et de riches chromatismes" (ZIELÍNSKI, 1995, p. 455).

“A complexidade harmônica aqui é impressionante, assim como a audácia das associações ornamentadas com a enarmonia e ricos cromatismos" (ZIELÍNSKI, 1995, p. 455). 
p. 142

Was die konkreten Ausformungen dieser Modelle im musikalischen Kunstwerk für Werkstil oder für den Ausdruck bedeuten, muß in jedem einzelnen Fall eigens geprüft werden (SEIDEL, 1969, p. 291).

O que as transformações concretas desses modelos significam para o estilo da obra ou para a expressão na obra de arte musical, precisam ser expressamente verificadas em cada caso (SEIDEL, 1969, p. 291).

\section{p. 143}

“Komponieren schließt im hier behandelten Zeitraum, dem späteren 18. und dem 19. Jahrhundert, die Verwendung, Anverwandlung und Umformung bekannter Formeln [...]" (DITTRICH, 2007, p. 107).

. [...] compor inclui, nesta época que tratamos aqui, ou seja, o final do século XVIII e início do XIX, a utilização, a transformação e a transfiguração de fórmulas conhecidas [...]" (DITTRICH, 2007, p. 107). 


\begin{tabular}{|c|c|c|c|c|}
\hline $\begin{array}{l}\text { Cd } \\
\text { Faixa }\end{array}$ & $\begin{array}{c}\text { № do } \\
\text { exemplo }\end{array}$ & Compositor & Música & $\mathrm{Pg}$. \\
\hline 1 & 7 & Beethoven & Sonata Op. 2 no 3, 1으. mov. & 13 \\
\hline 2 & 9 & Reinecke & Concerto para flauta Op. 283,19 mov. & 14 \\
\hline 3 & 11 & C.P. E. Bach & Rondó 3 em Lá menor & 15 \\
\hline 4 & 12 & Mozart & Trio para piano, violino e violoncelo KV 542 & 18 \\
\hline 5 & 13 & Scriabin & Terceira Sonata para piano Op. 23,19 mov. & 19 \\
\hline 6 & 16 & Chopin & Rondo Op. 73 & 21 \\
\hline 7 & 19 & Chopin & Noturno Op. 9 no 3 & 24 \\
\hline 8 & 21 & Liszt & Ab irato & 27 \\
\hline 9 & 23 & Chopin & Estudo Op. 10 no 9 & 28 \\
\hline 10 & 25 & Liszt & Segundo Estudo de Concerto "La Leggerezza" & 30 \\
\hline 11 & 26 & Liszt & Segundo Estudo de Concerto "La Leggerezza" & 31 \\
\hline 12 & 27 & Liszt & Sonata Dante & 32 \\
\hline 13 & 29 & Liszt & Terceiro Estudo de Concerto "Suspiro" & 35 \\
\hline 14 & 34 & Schubert & Sonata D845 em Lám & 42 \\
\hline 15 & 37 & Mendelssohn & Variações Sérias Op. 54, var. 9 & 43 \\
\hline 16 & 46 & Scott Joplin & Concert waltz "Bethena" & 52 \\
\hline 17 & 47 & Tschaikovsky & Sexta Sinfonia Op.74 em Si menor, 1ㅇ mov. & 53 \\
\hline 3 & 49 & C.P. E. Bach & Rondó 3 em Lá menor & 56 \\
\hline 18 & 50 & Chopin & Noturno Op. $55 n \div 2$ & 58 \\
\hline 19 & 51 & Haydn & Sinfonia no 98, 4ㅇ mov. & 59 \\
\hline 20 & 52 & Schubert & Lied Meeres Stille & 60 \\
\hline 21 & 53 & Meyerbeer & Robert le Diable, ato 1, cena 6 & 61 \\
\hline 22 & 54 & Berg & Schliesse Mir Die Augen Beide & 63 \\
\hline 23 & 55 & Rossini & William Tell, abertura & 63 \\
\hline 24 & 56 & Schubert & Der Wegweiser do ciclo Winterreise & 64 \\
\hline 25 & 57 & Chopin & Estudo Op. $25 n \circ 11$ & 69 \\
\hline 26 & 58 & Chopin & Prelúdio Op. $28 n \div 8$ & 70 \\
\hline 27 & $59 a$ & Chopin & Rondo Op. 73 & 73 \\
\hline 28 & $59 b$ & Chopin & Rondo Op. 73 & 73 \\
\hline 29 & $60 a$ & Chopin & Noturno Op. $55 n \div 2$ & 75 \\
\hline 30 & $60 b$ & Chopin & Noturno Op. $55 n \div 2$ & 75 \\
\hline 31 & $60 c$ & Chopin & Noturno Op. 55 no 2 & 75 \\
\hline 32 & 61 & Chopin & Segundo Concerto para piano e orquestra Op. 21 & 76 \\
\hline 33 & 62 & Chopin & Polonaise Op. $26 n \circ 1$ & 79 \\
\hline 34 & 63 & Chopin & Noturno Op. $55 n \circ 1$ & 80 \\
\hline 35 & 64 & Chopin & Valsa Op. 42 & 82 \\
\hline 36 & 65 & Chopin & Prelúdio Op. $28 n \div 9$ & 83 \\
\hline 37 & 67 & Chopin & Estudo Op. 10 no 8 & 85 \\
\hline 38 & 70 & Chopin & Noturno Op. $48 n^{\circ}=1$ & 88 \\
\hline 39 & 71 & Chopin & Fantasia Op. 49 & 89 \\
\hline 40 & 72 & Chopin & Mazurka Opus 41 no 2 & 90 \\
\hline
\end{tabular}




\begin{tabular}{|c|c|l|l|c|}
\hline $\begin{array}{c}\text { Cd } \\
\text { Faixa }\end{array}$ & $\begin{array}{c}\text { No do } \\
\text { exemplo }\end{array}$ & \multicolumn{1}{|c|}{ Música } & Pg. \\
\hline 41 & 75 & Chopin & Sonata Op. 65 para violoncelo e piano, 10 mov. & 93 \\
\hline 42 & 76 & Bach & Fantasia Cromática em Ré menor BWV 903 & 94 \\
\hline 43 & 78 & Chopin & Melodia Op. 74 no 9 & 98 \\
\hline 43 & 79 & Chopin & Melodia Op. 74 no 9 & 99 \\
\hline 43 & 80 & Chopin & Melodia Op. 74 no 9 & 100 \\
\hline 44 & 83 & Chopin & Prelúdio Op. 28 no 2 & 105 \\
\hline 45 & 84 & Bach & Paixão Segundo São Mateus, recitativo 73 & 106 \\
\hline 46 & 85 & Chopin & Prelúdio Op. 28 no 2 na íntegra & 107 \\
\hline 47 & 86 & Chopin & Prelúdio Op. 28 no 17 & 109 \\
\hline 48 & 87 & Chopin & Noturno Op. 15 no 2 & 110 \\
\hline 49 & 90 & Chopin & Fantasia Op. 49 & 115 \\
\hline 50 & 92 & Chopin & Mazurka Op. 68 no 4 & 117 \\
\hline 51 & 94 & Chopin & Noturnos Op. 27 no 1 e 2 & 121 \\
\hline 52 & 95 & Chopin & Noturnos Op. 27 no 1 & 122 \\
\hline 52 & 96 & Chopin & Noturnos Op. 27 no 1 & 123 \\
\hline 53 & 98 & Chopin & Noturnos Op. 27 no 2 & 127 \\
\hline 54 & $100 a$ & Chopin & Noturno Op. 27 no 2 & 129 \\
\hline 55 & $100 b$ & Chopin & Noturno Op. 27 no 2 & 132 \\
\hline 55 & 104 & Chopin & Noturno Op. 27 no 2 & \\
\hline
\end{tabular}

